\title{
GROUND-WATER CONDITIONS IN GEORGIA, 1995
}

\author{
U.S. GEOLOGICAL SURVEY
}

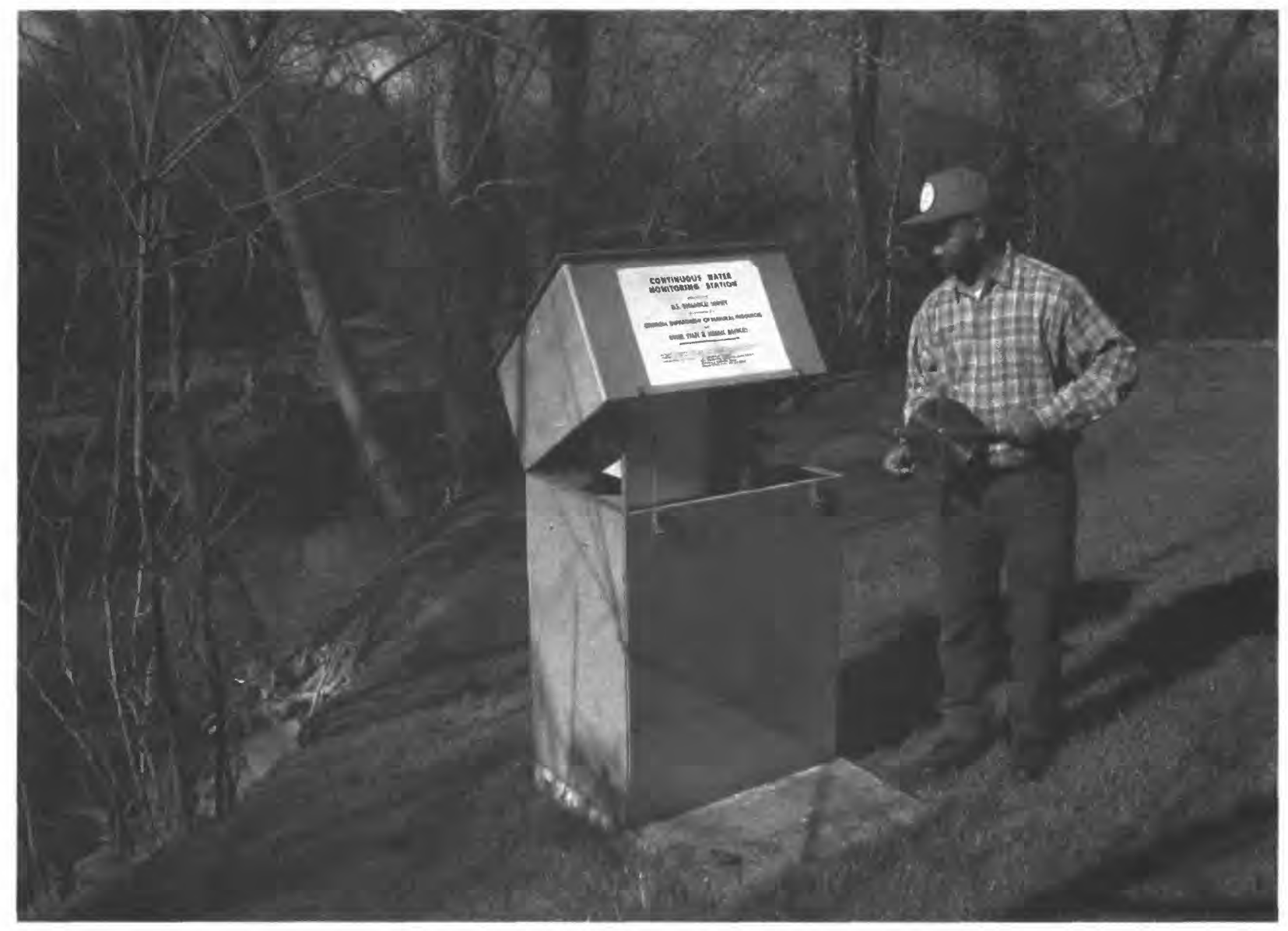

Prepared in cooperation with the

GEORGIA DEPARTMENT OF NATURAL RESOURCES

ENVIRONMENTAL PROTECTION DIVISION

GEORGIA GEOLOGIC SURVEY

ALBANY WATER, GAS, AND LIGHT COMMISSION

CITY OF BRUNSWICK

GLYNN COUNTY

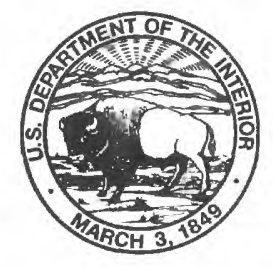

OPEN-FILE REPORT 96-200 


\section{PREFACE}

This report was prepared in cooperation with the following agencies, whose assistance in collecting and compiling water-level and water-quality data during 1995 is gratefully acknowledged:

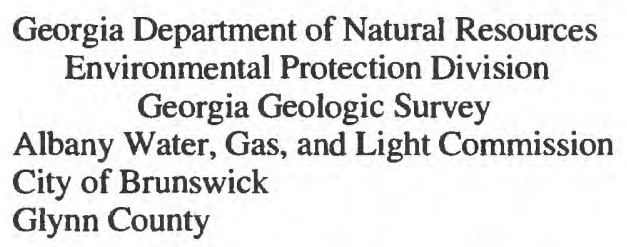

The report is the culmination of a concerted effort by personnel of the U.S. Geological Survey who collected, compiled, analyzed, verified, and organized the data, and who edited and assembled the report. In addition to the authors, who had primary responsibility for ensuring that the information contained herein is accurate and complete, the following individuals contributed substantially to the collection, processing, tabulation, and review of the data:

\author{
Robert J. Allen \\ George A. Bailey \\ Nancy L. Barber \\ Carolyn A. Casteel \\ Steven D. Craigg \\ John H. Doss \\ Gregory B. Donley \\ David A. Early \\ Donald J. Everett \\ Charles M. Hacke \\ Charles N. Joiner
}

\author{
L. Elliott Jones \\ Stephen H. Jones \\ Richard E. Krause \\ William C. Lewis \\ R. Terry Nichols \\ Mark S. Reynolds \\ Welby L. Stayton \\ Charles G. Somerindyke \\ Blaine T. White \\ Caryl J. Wipperfurth
}

Data used in this report may be obtained upon request from the U.S. Geological Survey, Peachtree Business Center, Suite 130, 3039 Amwiler Road, Atlanta, GA 30360-2824.

[Cover: William C. Lewis, hydrologic technician, measuring the water level in recorder well 11FF04,

DeKalb County, Georgia.

Photo by Alan M. Cressler] 


\section{GROUND-WATER CONDITIONS IN GEORGIA, 1995}

By Alan M. Cressler

U.S. GEOLOGICAL SURVEY

Open-File Report 96-200

Prepared in cooperation with the

GEORGIA DEPARTMENT OF NATURAL RESOURCES

ENVIRONMENTAL PROTECTION DIVISION

GEORGIA GEOLOGIC SURVEY

\section{ALBANY WATER, GAS, AND LIGHT COMMISSION \\ CITY OF BRUNSWICK}

GLYNN COUNTY

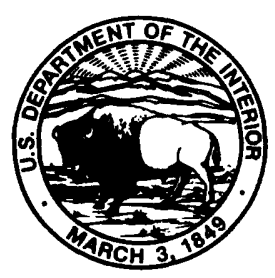

Atlanta, Georgia 


\title{
U.S. DEPARTMENT OF THE INTERIOR
}

\section{Bruce Babbitt, Secretary}

\author{
U.S. GEOLOGICAL SURVEY
}

Gordon P. Eaton, Director

For additional information, please write to:

District Chief

U.S. Geological Survey

Peachtree Business Center

Suite 130

3039 Amwiler Road

Atlanta, GA 30360-2824
Copies of this report may be purchased from:

U.S. Geological Survey

Earth Science Information Center

Open-File Reports Section

Denver Federal Center

Box 25286, Mail Stop 517

Denver, CO 80225 


\title{
CONTENTS
}

\author{
Abstract 1 \\ Introduction $\mathbf{2}$ \\ Purpose and scope 2 \\ Well-numbering system 2 \\ Ground-water resources 3 \\ Ground-water levels 6 \\ Surficial aquifers 9 \\ Northern area 9 \\ Southwestern area 9 \\ Coastal area 9 \\ Upper Brunswick aquifer 19 \\ Floridan aquifer system $\mathbf{2 3}$ \\ Upper Floridan aquifer $\mathbf{2 3}$ \\ Southwestern area 23 \\ South-central area 23 \\ East-central area 24 \\ Savannah area 24 \\ Jesup-Doctortown area $\mathbf{2 4}$ \\ Brunswick area $\mathbf{2 4}$ \\ St Marys-Okefenokee Swamp area 24 \\ Lower Floridan aquifer in the Brunswick area $\mathbf{5 7}$ \\ Claiborne aquifer $\mathbf{6 0}$ \\ Clayton aquifer 69 \\ Cretaceous aquifers and aquifer systems $\mathbf{7 7}$ \\ Providence aquifer $\mathbf{7 7}$ \\ Dublin aquifer system $\mathbf{7 7}$ \\ Midville aquifer system $\mathbf{7 7}$ \\ Dublin-Midville aquifer system $\mathbf{7 7}$ \\ Paleozoic-rock aquifers $\mathbf{8 6}$ \\ Crystalline-rock aquifers $\mathbf{8 8}$ \\ Chloride concentration in water from the Floridan aquifer system $\mathbf{9 4}$ \\ Savannah area 95 \\ Brunswick area 97 \\ Selected references $\mathbf{1 0 0}$
}




\section{ILLUSTRATIONS}

Figures 1-3. Maps showing:

1. Major aquifers and physiographic provinces of Georgia 5

2. Locations of observation wells for which hydrographs are included in this report 8

3. Locations of observation wells completed in the surficial aquifers $\mathbf{1 0}$

Figures 4-11. Hydrographs showing the water level in observation well:

4. 11AA01, Spalding County 11

5. 13M007, Worth County 12

6. 07H003, Miller County 13

7. $35 \mathrm{P} 094$, Chatham County 14

8. 37P116, Chatham County 15

9. 32R003, Bulloch County 16

10. $34 \mathrm{H} 438$, Glynn County 17

11. 32L017, Wayne County 18

Figure 12. Map showing locations of observation wells completed in the upper Brunswick aquifer 19

Figures 13-15. Hydrographs showing the water level in observation well:

13. 31U009, Bulloch County 20

14. 32L016, Wayne County 21

15. 34H437, Glynn County 22

Figure 16. Map showing subareas and locations of observation wells completed in the Upper Floridan aquifer 25

Figures 17-47. Hydrographs showing the water level in observation well:

17. 09F520, Decatur County 26

18. 08G001, Miller County 27

19. 06F001, Seminole County 28

20. 13L012, Dougherty County 29

21. 10G313, Mitchell County 30

22. 13L003, Dougherty County 31

23. 13J004, Mitchell County 32

24. 15L020, Worth County 33

25. 18K049, Tift County 34

26. $18 \mathrm{H} 016$, Cook County 35

27. 19E009, Lowndes County 36

28. 19F039, Lowndes County 37

29. 21T001, Laurens County 38

30. 25Q001, Montgomery County 39

31. 26R001, Toombs County 40

32. $36 \mathrm{Q} 008$, Chatham County 41

33. 36Q020, Chatham County 42

34. 38Q002, Chatham County 43

35. 39Q003, Chatham County 44

36. 32R002, Bulloch County 45

37. 34 N089, Liberty County 46

38. 35M013, McIntosh County 47

39. 30L003, Wayne County 48

40. 32L015, Wayne County 49

41. 33M004, Long County $\mathbf{5 0}$

42. 33H127, Glynn County 51

43. 34H403, Glynn County 52

44. 33H133, Glynn County $\mathbf{5 3}$

45. 34H371, Glynn County $\mathbf{5 4}$

46. 33E027, Camden County 55

47. 27E004, Charlton County 56 


\section{ILLUSTRATIONS-Continued}

Figure 48. Map showing locations of observation wells completed in the Lower Floridan aquifer 57

Figures 49-50. Hydrographs showing the water level in observation well:

49. 34H391, Glynn County $\mathbf{5 8}$

50. 33J044, Glynn County $\mathbf{5 9}$

Figure 51. Map showing locations of observation wells completed in the Claiborne aquifer $\mathbf{6 0}$

Figures 52-59. Hydrographs showing the water level in observation well:

52. 06K010, Early County 61

53. 09M009, Randolph County 62

54. $11 \mathrm{~K} 002$, Dougherty County 63

55. 11L001, Dougherty County 64

56. 12L019, Dougherty County 65

57. 13L011, Dougherty County 66

58. 13M005, Worth County 67

59. 14P015, Crisp County 68

Figure $\quad 60$. Map showing locations of observation wells completed in the Clayton aquifer 69

Figures 61-67. Hydrographs showing the water level in observation well:

61. 06K009, Early County 70

62. 07N001, Randolph County 71

63. 09N001, Terrell County $\mathbf{7 2}$

64. 11L002, Dougherty County 73

65. 13L002, Dougherty County $\mathbf{7 4}$

66. 11 K005, Dougherty County 75

67. 14P014, Crisp County 76

Figure 68. Map showing locations of observation wells completed in Cretaceous aquifers and aquifer systems 78

Figures 69-75. Hydrographs showing the water level in observation well:

69. 06S001, Chattahoochee County 79

70. 12L021, Dougherty County 80

71. 18U001, Twiggs County $\mathbf{8 1}$

72. 18T001, Pulaski County $\mathbf{8 2}$

73. 28X001, Burke County $\mathbf{8 3}$

74. 30AA04, Richmond County $\mathbf{8 4}$

75. 23X027, Washington County 85

Figure 76. Map showing location of observation well completed in a Paleozoic-rock aquifer 86

Hydrograph showing the water level in observation well:

77. 03PP01, Walker County 87

78. Map showing locations of observation wells completed in crystalline-rock aquifers $\mathbf{8 8}$

Figures 79-83. Hydrographs showing the water level in observation well:

79. 10DD02, Fulton County 89

80. $19 \mathrm{HH} 12$, Madison County 90

81. 11FF04, DeKalb County 91

82. 21BB04, Greene County 92

83. 16MM03, White County 93

Figure $\quad$ 84. Map showing locations of chloride monitoring wells completed in the Floridan aquifer in the Savannah area 95

Figure 85. Graphs showing chloride concentrations in water from the Upper and Lower Floridan aquifers in the Savannah area 96

86. Map showing locations of chloride-monitoring wells completed in the Floridan aquifer system in the Brunswick area 97

Figures $\quad 87-88 . \quad$ Graphs showing chloride concentration in water from the:

87. Floridan aquifer system in the southern Brunswick area 98

88. Upper Floridan aquifer in the northern Brunswick area 


\section{TABLES}

Table 1. Previous reports on ground-water conditions in Georgia 3

2. Aquifer and well characteristics in Georgia 4

3. Observation wells for which hydrographs are included in this report 6

4. Observation wells for which chloride-concentration graphs are included in this report 94 


\section{CONVERSION FACTORS AND VERTICAL DATUM}

\section{CONVERSION FACTORS}

$\begin{array}{lrl}\text { Multiply } & \underline{\text { by }} & \underline{\text { to obtain }} \\ & \underline{\text { Length }} & \\ & & \\ \text { foot (ft) } & 0.3048 & \text { meter } \\ \text { mile (mi) } & 1.609 & \text { kilometer }\end{array}$

$\underline{\text { Volume }}$

gallon per minute

$(\mathrm{gal} / \mathrm{min})$

million gallons per day

(Mgal/d)
0.06309

0.04381

43.81 liter per second

cubic meter per second liter per second

VERTICAL DATUM

Sea Level-In this report, "sea level" refers to the National Geodetic Vertical Datum of 1929-a geodetic datum derived from a general adjustment of the first-order level nets of both the United States and Canada, formerly called "Sea Level Datum of 1929." 


\title{
GROUND-WATER CONDITIONS IN GEORGIA, 1995
}

\author{
By
}

\author{
Alan M. Cressler
}

\begin{abstract}
Ground-water conditions in Georgia during 1995 and for the period of record were evaluated using data from ground-water-level and ground-water-quality monitoring networks. Data for 1995 included in this report are from continuous water-level records from 72 wells and chloride analyses from 13 well

Annual mean ground-water levels in Georgia in 1995 ranged from 7.8 feet (ft) lower to $3.2 \mathrm{ft}$ higher than in 1994. Of the 72 wells summarized in this report, 28 wells had annual mean water levels that were higher, 35 wells had annual mean water levels that were lower, and nine wells had annual mean water levels that were the same in 1995 as in 1994. Record-high daily mean water levels were recorded in one well tapping the Upper Floridan aquifer, two wells tapping the Lower Floridan aquifer, two wells tapping the Claiborne aquifer, and one well tapping the Paleozoic-rock aquifer. These record highs were from $0.1 \mathrm{ft}$ to $0.9 \mathrm{ft}$ higher than previous record highs. Record-low daily mean water levels were recorded in one well tapping the Upper Floridan aquifer, two wells tapping the Claiborne aquifer, one well tapping the Clayton aquifer, one well tapping the Cretaceous aquifer, one well tapping the Dublin-Midville aquifer system, and one well tapping a crystalline-rock aquifer. These record lows were from 0.1 to $6.7 \mathrm{ft}$ lower than previous record lows.

Chloride concentration in water from the Upper Floridan aquifer in most of coastal Georgia was below drinking-water standards established by the Georgia Department of Natural Resources and the U.S. Environmental Protection Agency. In the Savannah area, chloride concentration has not changed appreciably with time. However, chloride concentration in water from some wells that tap the Floridan aquifer system in the Brunswick area exceeds the drinking-water standards. In the northern Brunswick area, chloride concentration has been increasing since sampling began in 1966.
\end{abstract}




\section{INTRODUCTION}

Ground-water-level and ground-water-quality data are essential for water assessment and management. Ground-water-level fluctuations and trends can be used to estimate changes in aquifer storage resulting from the effects of ground-water withdrawal and recharge from precipitation. These data can be used to address watermanagement needs and to evaluate the effects of management and conservation programs.

As part of the ground-water investigations conducted by the U.S. Geological Survey (USGS), in cooperation with the State of Georgia and city and county governments, a Statewide water-level-measurement program was started in 1938. Initially, this program consisted of an observation-well network in the coastal area of Georgia to monitor variations in ground-water storage and quality. Additional wells were included later in areas where the data could be used to predict potential water-resources problems.

During 1995, periodic water-level measurements were made in 233 wells, and continuous water- level measurements were obtained from an additional 164 wells. Continuous water-level records were obtained using analog (pen and chart) recorders, digital recorders that record water levels at 30-minute or 60 -minute intervals, and electronic data recorders that record water levels at 60 -minute intervals. For wells having incomplete water-level record, water levels during periods of missing record may have been higher or lower than recorded water levels. Water samples collected from 20 wells during November 1995 were analyzed to determine chloride concentration in the Savannah and Brunswick areas.

\section{Purpose and Scope}

This report presents selected ground-water-level and ground-water-quality data for Georgia for calendar year 1995. Graphs showing ground-water levels in 72 wells are presented. Graphs show chloride concentrations of water from 13 wells tapping the Floridan aquifer system in the Savannah and Brunswick areas. The text includes a brief discussion of the aquifers and the aquifer systems, ground-water levels, and chloride concentration in water. An extensive list of references of water-resources investigations are presented in "Selected References"; previously published reports on Georgia ground-water conditions are listed in table 1.

\section{Well-Numbering System}

Wells described in this report are numbered according to a system based on the USGS index of topographic maps of Georgia. Each 7 1/2-minute topographic quadrangle in the State has been assigned a six-digit number and letter designation beginning at the southwestern corner of the State. Numbers increase sequentially eastward and letters advance alphabetically northward. Quadrangles in the northern part of the State are designated by double letters; AA follows Z, and so forth. The letters "I", "O", "II", and "OO" are not used. Wells inventoried in each quadrangle are numbered consecutively, beginning with 01 . Thus, the fourth well scheduled in the 11AA quadrangle is designated 11AA04. 
Table 1. Previous reports on ground-water conditions in Georgia [USGS, U.S. Geological Survey]

\begin{tabular}{|c|c|c|c|}
\hline $\begin{array}{c}\text { Year of } \\
\text { data } \\
\text { collection }\end{array}$ & $\begin{array}{c}\text { USGS } \\
\text { Open-File } \\
\text { Report } \\
\text { number }\end{array}$ & Author(s) & $\begin{array}{c}\text { Year of } \\
\text { publication }\end{array}$ \\
\hline 1977 & $79-213$ & None listed & 1978 \\
\hline 1978 & $79-1290$ & Clarke, J.S., Hester, W.G., and O'Byrne, M.P. & 1979 \\
\hline 1979 & $80-501$ & Mathews, S.E., Hester, W.G., and O'Byrne, M.P. & 1980 \\
\hline 1980 & $81-1068$ & Mathews, S.E., Hester, W.G., and O'Byrne, M.P. & 1981 \\
\hline 1981 & $82-904$ & Mathews, S.E., Hester, W.G., and McFadden, K.W. & 1982 \\
\hline 1982 & $83-678$ & Stiles, H.R., and Mathews, S.E. & 1983 \\
\hline 1983 & $84-605$ & Clarke, J.S., Peck, M.F., Longsworth, S.A., and McFadden, K.W. & 1984 \\
\hline 1984 & $85-331$ & Clarke, J.S., Longsworth, S.A., McFadden, K.W., and Peck, M.F. & 1985 \\
\hline 1985 & $86-304$ & $\begin{array}{l}\text { Clarke, J.S., Joiner, C.N., Longsworth, S.A., McFadden, K.W., and } \\
\text { Peck, M.F. }\end{array}$ & 1986 \\
\hline 1986 & $87-376$ & $\begin{array}{l}\text { Clarke, J.S., Longsworth, S.A., Joiner, C.N., Peck, M.F., McFadden, } \\
\text { K.W., and Milby, B.J. }\end{array}$ & 1987 \\
\hline 1987 & $88-323$ & Joiner, C.N., Reynolds, M.S., Stayton, W.L., and Boucher, F.G. & 1988 \\
\hline 1988 & $89-408$ & Joiner, C.N., Peck, M.F., Reynolds, M.S., and Stayton, W.L. & 1989 \\
\hline 1989 & $90-706$ & Peck, M.F., Joiner, C.N., Clarke, J.S., and Cressler, A.M. & 1990 \\
\hline 1990 & $91-486$ & Milby, B.J., Joiner, C.N., Cressler, A.M., and West, C.T. & 1991 \\
\hline 1991 & $92-470$ & Peck, M.F., Joiner, C.N., and Cressler, A.M. & 1992 \\
\hline 1992 & $93-358$ & Peck, M.F., and Cressler, A.M. & 1993 \\
\hline 1993 & $94-118$ & Joiner, C.N., and Cressler, A.M. & 1994 \\
\hline 1994 & $95-302$ & Cressler, A.M., Jones, L.E., and Joiner, C.N. & 1995 \\
\hline
\end{tabular}

\section{GROUND-WATER RESOURCES}

Contrasting geologic features and landforms of the physiographic provinces of Georgia (table 2, fig. 1) result in substantial differences in ground-water conditions from one part of the State to another. These features that make up the framework of the aquifers affect the quantity and quality of the ground water throughout the State.

Surficial aquifers are present in each of the physiographic provinces. In the Piedmont, Blue Ridge, and Valley and Ridgè Provinces (fig. 1), the surficial aquifers consist of soil, saprolite, stream alluvium, colluvium, and other surficial deposits. In the Coastal Plain Province, the surficial aquifers consist of intermixed layers of sand, clay, and limestone. The surficial aquifers usually are under water-table (unconfined) conditions and are used for domestic and livestock supplies. These aquifers can be semiconfined locally in the coastal area.

In the Piedmont and Blue Ridge Provinces, rocks are complex and consist of structurally deformed metamorphic and igneous rocks. Ground water is transmitted through secondary openings along fractures, foliation, joints, contacts, or other features in the crystalline bedrock. In the Valley and Ridge Province, ground water is transmitted through both primary and secondary openings in folded and faulted sedimentary and metasedimentary rocks of Paleozoic age.

The most productive aquifers in Georgia are in the Coastal Plain Province in the southern part of the State. The Coastal Plain is underlain by alternating layers of sand, clay, and limestone that dip and thicken to the southeast. In the Coastal Plain, aquifers generally are confined, except near their northern limits, where they crop out or are near land surface. Aquifers in the Coastal Plain include the upper Brunswick aquifer, the lower Brunswick aquifer, the Floridan aquifer system, the Claiborne aquifer, the Clayton aquifer, and the Cretaceous aquifers and aquifer systems. 
Table 2. Aquifer and well characteristics in Georgia

[modified from Clarke and PIerce (1984) and Peck and others (1992); ft, feet; gal/min, gallons per minute]

\begin{tabular}{|c|c|c|c|c|}
\hline \multirow{3}{*}{ Aquifer name and description } & \multicolumn{3}{|c|}{ Well characteristics } & \multirow{3}{*}{ Remarks } \\
\hline & \multirow{2}{*}{$\frac{\text { Depth }(\mathrm{ft})}{\begin{array}{c}\text { Common } \\
\text { range }\end{array}}$} & \multicolumn{2}{|c|}{ Yield (gal/min) } & \\
\hline & & $\begin{array}{l}\text { Common } \\
\text { range }\end{array}$ & $\begin{array}{c}\text { May } \\
\text { exceed }\end{array}$ & \\
\hline $\begin{array}{l}\text { Surficial aquifer: } \\
\text { Unconsolidated sediments, } \\
\text { generally unconfined }\end{array}$ & $11-72$ & $2-25$ & 25 & $\begin{array}{l}\text { Primary source of water for domestic and livestock supply } \\
\text { in rural areas. Supplemental source of water in coastal } \\
\text { Georgia }\end{array}$ \\
\hline $\begin{array}{l}\text { Uppper and Lower Brunswick } \\
\text { aquifers: } \\
\text { Phosphatic and dolomitic } \\
\text { quartz sand, generally } \\
\text { confined }\end{array}$ & $85-390$ & $10-30$ & 180 & $\begin{array}{l}\text { Not a major source of water in coastal Georgia, but } \\
\text { considered a supplemental water supply to the Upper } \\
\text { Floridan aquifer. Most wells are multi-aquifer, tapping } \\
\text { the upper and lower Brunswick aquifers and the Upper } \\
\text { Floridan aquifer. The lower Brunswick aquifer } \\
\text { currently is not monitored (Clarke and others, 1990, } \\
\text { p. 26-28). }\end{array}$ \\
\hline $\begin{array}{l}\text { Floridan aquifer system: } \\
\text { Limestone, dolomite, and } \\
\text { calcareous sand, generally } \\
\text { confined }\end{array}$ & $40-900$ & $1,000-5,000$ & 11,000 & $\begin{array}{l}\text { Supplies } 50 \text { percent of ground water in Georgia. The } \\
\text { aquifer system is divided into the Upper and Lower } \\
\text { Floridan aquifers. In the Brunswick area, the Upper } \\
\text { Floridan aquifer includes two freshwater-bearing } \\
\text { zones, the upper water-bearing zone and the lower } \\
\text { water-bearing zone. The Lower Floridan aquifer is not } \\
\text { considered a major aquifer. In the Brunswick area and } \\
\text { southeastern Georgia, the Lower Floridan aquifer } \\
\text { includes the brackish-water zone, the deep freshwater, } \\
\text { and the Fernandina permeable zone (Krause and } \\
\text { Randolph, 1989), which extends to more than } 2,700 \mathrm{ft} \\
\text { and yields high-chloride water below 2,300 ft (Jones } \\
\text { and Maslia, 1994). Formerly called the principal } \\
\text { artesian aquifer. }\end{array}$ \\
\hline $\begin{array}{l}\text { Claiborne aquifer: } \\
\text { Sand and sandy limestone, } \\
\text { generally confined }\end{array}$ & $20-450$ & $150-600$ & 1,500 & $\begin{array}{l}\text { Major source of water for irrigation, industrial, and } \\
\text { public-supply use in southwestern Georgia. }\end{array}$ \\
\hline $\begin{array}{l}\text { Clayton aquifer: } \\
\text { Limestone and sand, } \\
\text { generally confined }\end{array}$ & $40-800$ & $250-600$ & 2,150 & $\begin{array}{l}\text { Major source of water for irrigation, industrial, and } \\
\text { public-supply use in southwestern Georgia. }\end{array}$ \\
\hline $\begin{array}{l}\text { Cretaceous aquifers and aquifer } \\
\text { systems: } \\
\text { Sand and gravel, generally } \\
\text { confined }\end{array}$ & $30-750$ & $50-1,200$ & 3,300 & $\begin{array}{l}\text { Major source of water in east-central Georgia. Supplies } \\
\text { water for kaolin mining and processing. Includes the } \\
\text { Providence aquifer in southwestern Georgia, and the } \\
\text { Dublin, Midville, and Dublin-Midville aquifer systems } \\
\text { in east-central Georgia. }\end{array}$ \\
\hline $\begin{array}{l}\text { Paleozoic-rock aquifers: } \\
\text { Sandstone, limestone, and } \\
\text { dolostone }\end{array}$ & $15-2,100$ & $1-50$ & 3,500 & $\begin{array}{l}\text { Not laterally extensive. Limestone and dolostone aquifers } \\
\text { are most productive. Storage is in regolith, primary } \\
\text { openings, and secondary fractures and solution } \\
\text { openings in rock. Springs in limestone and dolostone } \\
\text { aquifers discharge at rates of as much as } 5,000 \mathrm{gal} / \mathrm{min} \text {. } \\
\text { Sinkholes may form in areas of intensive pumping. }\end{array}$ \\
\hline $\begin{array}{l}\text { Crystalline-rock aquifers: } \\
\text { Granite, gneiss, schist, and } \\
\text { quartzite }\end{array}$ & $40-600$ & $1-25$ & 500 & $\begin{array}{l}\text { Not laterally extensive. Storage is in regolith and } \\
\text { fractures in rock. Hydrogeology of crystalline-rock } \\
\text { aquifers is not well understood. }\end{array}$ \\
\hline
\end{tabular}




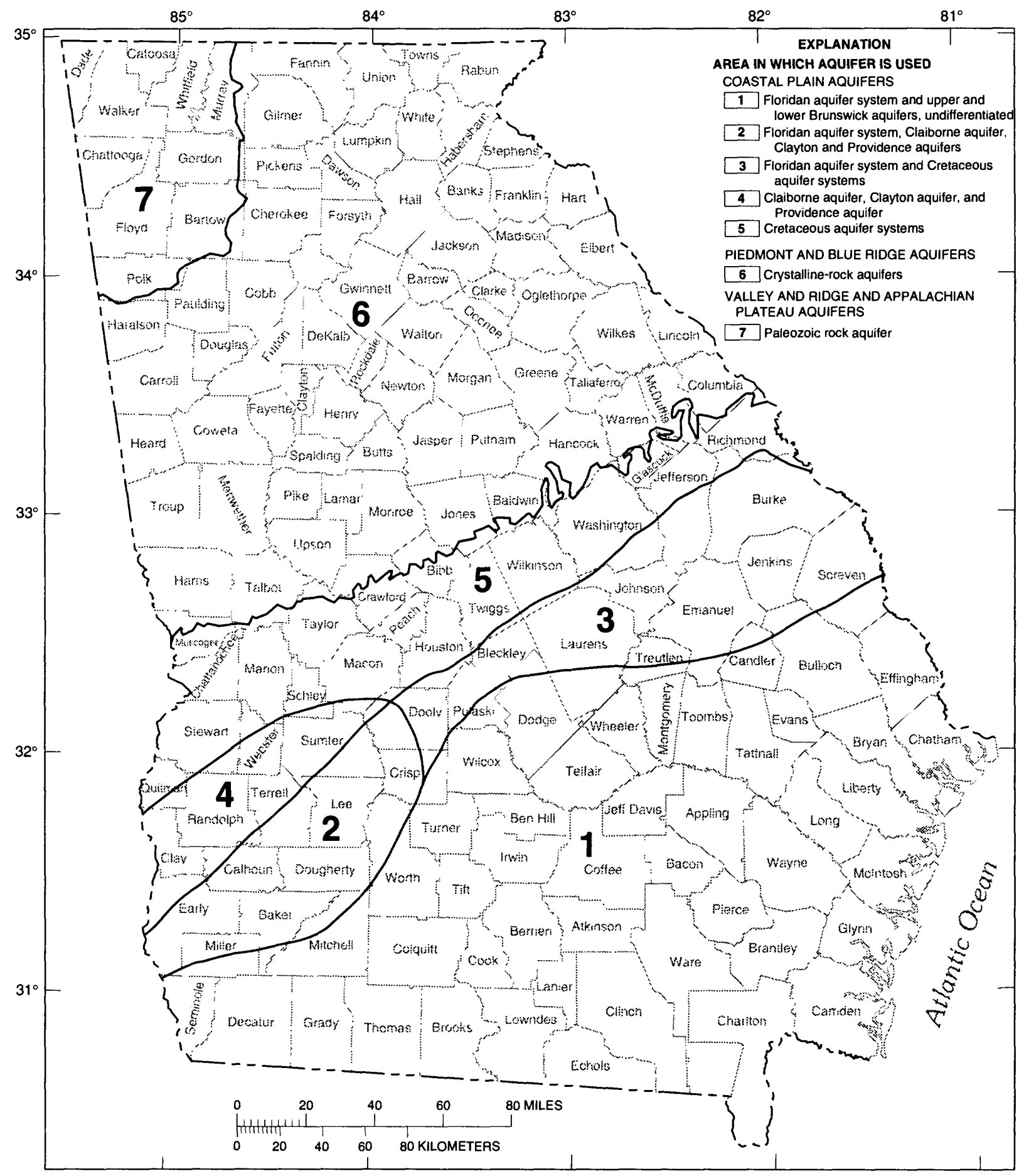

Base modified from U.S.Geologica: Survey State base map

Figure 1.-Areas of major aquifers in Georgia. [Modified from Peck and others, 1992.] 


\section{GROUND-WATER LEVELS}

Short-term fluctuation and long-term trends in ground-water levels are results of variations in recharge and discharge. Recharge varies in response to precipitation and surface-water infiltration into an aquifer. Discharge occurs as natural flow from an aquifer to streams and springs, as evapotranspiration, and as withdrawal from wells.

Discussions of the ground-water levels in Georgia are grouped by aquifer and subdivided into areas and subareas in which wells had similar water-level fluctuations and trends. For each section, 1995 annual mean water levels are compared to 1994 annual mean water levels (Cressler and others, 1995). Also given are all occurrences of record-low or record-high water levels in 1995. In these discussions, water-level differences are reported to the nearest $0.1 \mathrm{ft}$ and the term "the same" is used for differences less than or equal to $0.1 \mathrm{ft}$.

Water-level fluctuations in 1995 are shown for 72 continuously monitored wells (table 3, fig. 2), which are considered to be representative of ground-water levels throughout the State. For each well, well-site information is listed, monthly mean water levels are shown in hydrographs for the period of record, daily mean water levels are shown in hydrographs for 1995, and monthly and annual water-level statistics (minimum, mean, and maximum daily mean water levels) are tabulated for 1995. Monthly statistics are not computed for months having less than 25 days of record. Extreme water levels for the period of record listed in the well-site information and tabulated water-level statistics are reported to the nearest $0.01 \mathrm{ft}$, reflecting the accuracy of the recorders used. Land-surface data generally are determined from the best available topographic map, and are accurate to one-half the contour interval. Some landsurface data were determined by surveying methods and are more accurate. In this report, an extreme water level refers to the lowest or highest daily mean water level for the period of record of a particular well. Thus, any instantaneous water-level measurement on a given day may be lower or higher than the extreme water level reported in the text, the daily mean water level shown on the hydrograph, or the minimum or maximum values tabulated.

Continuous records from the 72 wells indicate that annual mean ground-water levels were from $7.8 \mathrm{ft}$ lower to $3.2 \mathrm{ft}$ higher in 1995 than in 1994. The annual mean water level was higher in 28 wells, lower in 35 wells, and the same in nine wells. Record-high daily mean water levels that were from 0.1 to $0.9 \mathrm{ft}$ higher than the previous highs were recorded in six wells; one tapping the Upper Floridan aquifer, two tapping the Lower Floridan aquifer, two tapping the Claiborne aquifer, and one tapping the Paleozoic-rock aquifer. Record-low daily mean water levels that were from 0.1 to $6.7 \mathrm{ft}$ lower than the previous record lows were measured in seven wells; one well tapping the Upper Floridan aquifer, two wells tapping the Claiborne aquifer, one well tapping the Clayton aquifer, one well tapping the Cretaceous aquifer, one well tapping the Dublin-Midville aquifer system, and one well tapping the crystalline-rock aquifer.

Table 3. Observation wells for which hydrographs are included in this report [GGS, Georgia Geologic Survey; USGS, U.S. Geological Survey; UGA, University of Georgia.]

\begin{tabular}{|c|c|c|c|c|}
\hline County & Aquifer & Well number & Site name & Page \\
\hline Bulloch & Upper Floridan & 32R002 & GGS, Bulloch South, test well 1 & 45 \\
\hline Bulloch & surficial & 32R003 & GGS, Bulloch South, test well 2 & 16 \\
\hline Bulloch & upper Brunswick & $31 \mathrm{U} 009$ & GGS, Hopeulikit, test well 2 & 20 \\
\hline Burke & Midville aquifer system & $28 \times 001$ & USGS, Midville, test well 1 & 83 \\
\hline Camden & Upper Floridan & $33 \mathrm{E} 027$ & U.S. Navy, Kings Bay, test well 1 & 55 \\
\hline Charlton & Upper Floridan & 27E004 & USGS, test well OK-9 & 56 \\
\hline Chatham & surficial & 35P094 & UGA, Bamboo Farm & 14 \\
\hline Chatham & Upper Floridan & 36Q008 & Layne-Atlantic Co. & 41 \\
\hline Chatham & Upper Floridan & $36 Q 020$ & H.J. Morrison & 42 \\
\hline Chatham & surficial & $37 \mathrm{P} 116$ & GGS, Skidaway Institute, test well 4 & 15 \\
\hline Chatham & Upper Floridan & $38 Q 002$ & National Park Service, test well 6 & 43 \\
\hline Chatham & Upper Floridan & 39Q003 & USGS, test well 7 & 44 \\
\hline Chattahoochee & Cretaceous formations & $06 S 001$ & U.S. Army, Fort Benning & 79 \\
\hline Cook & Upper Floridan & $18 \mathrm{H} 016$ & USGS, Adel test well & 35 \\
\hline Crisp & Clayton & 14P014 & GGS, Veterans Memorial State Park, test well I & 76 \\
\hline Crisp & Claiborne & 14P015 & GGS, Veterans Memorial State Park, test well 2 & 68 \\
\hline Decatur & Upper Floridan & 09F520 & Graham Bolton & 26 \\
\hline DeKalb & crystalline rock & $11 \mathrm{FF} 04$ & USGS, test well 5 & 91 \\
\hline Dougherty & Claiborne & $11 \mathrm{~K} 002$ & USGS, test well I1 & 63 \\
\hline Dougherty & Clayton & $11 \mathrm{~K} 005$ & USGS, test well 12 & 75 \\
\hline Dougherty & Claiborne & $11 \mathrm{LO01}$ & USGS, test well 4 & 64 \\
\hline
\end{tabular}


Table 3. Observation wells for which hydrographs are included in this report-Continued [GGS, Georgia Geologic Survey; USGS, U.S. Geological Survey; UGA, University of Georgia.]

\begin{tabular}{|c|c|c|c|c|}
\hline County & Aquifer & Well number & Site name & Page \\
\hline Dougherty & Clayton & $11 \mathrm{~L} 002$ & GGS, Albany Nursery & 73 \\
\hline Dougherty & Claiborne & $12 \mathrm{~L} 019$ & USGS, test well 5 & 65 \\
\hline Dougherty & Providence & 12L021 & USGS, test well 10 & 80 \\
\hline Dougherty & Clayton & 13L002 & Albany Water, Gas, and Light, Turner City 2 & 74 \\
\hline Dougherty & Upper Floridan & $13 \mathrm{~L} 003$ & City of Albany and Dougherty County & 31 \\
\hline Dougherty & Claiborne & 13L011 & USGS, test well 2 & 66 \\
\hline Dougherty & Upper Floridan & 13L012 & USGS, test well 3 & 29 \\
\hline Early & Clayton & 06К009 & GGS, Kolomoki Mounds State Park, test well 1 & 70 \\
\hline Early & Claiborne & 06K010 & GGS, Kolomoki Mounds State Park, test well 2 & 61 \\
\hline Fulton & crystalline rock & 10DD02 & U.S. Army, Fort McPherson & 89 \\
\hline Glynn & Upper Floridan & $33 \mathrm{H} 127$ & USGS, test well 3 & 51 \\
\hline Glynn & Upper Floridan & $33 \mathrm{H} 133$ & USGS, test well 6 & 53 \\
\hline Glynn & Lower Floridan & 33J044 & Georgia Pacific Company, USGS, test well 27 & 59 \\
\hline Glynn & Upper Floridan & $34 \mathrm{H} 371$ & USGS, test well 11 & 54 \\
\hline Glynn & Lower Floridan & $34 \mathrm{H} 391$ & USGS, test well 16 & 58 \\
\hline Glynn & Upper Floridan & $34 \mathrm{H} 403$ & USGS, test well 24 & 52 \\
\hline Glynn & upper Brunswick & $34 \mathrm{H} 437$ & GGS, Coffin Park, test well 2 & 22 \\
\hline Glynn & surficial & $34 \mathrm{H} 438$ & GGS, Coffin Park, test well 3 & 17 \\
\hline Greene & crystalline rock & 21BB04 & Charles Veazey & 92 \\
\hline Laurens & Upper Floridan & $21 \mathrm{~T} 001$ & Danny Hogan & 38 \\
\hline Liberty & Upper Floridan & 34 N089 & USGS, test well 1 & 46 \\
\hline Long & Upper Floridan & 33M004 & USGS, test well 3 & 50 \\
\hline Lowndes & Upper Floridan & 19E009 & City of Valdosta & 36 \\
\hline Lowndes & Upper Floridan & 19F039 & City of Valdosta, well 8 & 37 \\
\hline Madison & crystalline rock & $19 \mathrm{HH} 12$ & Meadowlake Estates & 90 \\
\hline McIntosh & Upper Floridan & $35 \mathrm{M} 013$ & U.S. Fish and Wildlife Service & 47 \\
\hline Miller & surficial & $07 \mathrm{H} 003$ & USGS, test well DP-3 & 13 \\
\hline Miller & Upper Floridan & 08G001 & Viercocken & 27 \\
\hline Mitchell & Upper Floridan & $10 \mathrm{G} 313$ & Harvey Meinders & 30 \\
\hline Mitchell & Upper Floridan & $13 \mathrm{~J} 004$ & Aurora Dairy & 32 \\
\hline Montgomery & Upper Floridan & $25 \mathrm{Q} 001$ & Montgomery County Board of Education & 39 \\
\hline Pulaski & Midville aquifer system & $18 \mathrm{~T} 001$ & USGS, Arrowhead, test well 1 & 82 \\
\hline Randolph & Clayton & 07N001 & City of Cuthbert & 71 \\
\hline Randolph & Claiborne & 09M009 & C.T. Martin, test well 1 & 62 \\
\hline Richmond & Dublin-Midville aquifer system & 30AA04 & Richmond County water system, USGS, McBean 2 & 84 \\
\hline Seminole & Upper Floridan & $06 \mathrm{~F} 001$ & Roddenbery Company Farms, test well 1 & 28 \\
\hline Spalding & surficial & 11AA01 & UGA, Experiment Station & 11 \\
\hline Terrell & Clayton & 09N001 & Bill Newman & 72 \\
\hline Tift & Upper Floridan & $18 \mathrm{~K} 049$ & USGS, test well 1 & 34 \\
\hline Toombs & Upper Floridan & 26R001 & City of Vidalia, well 2 & 40 \\
\hline Twiggs & Dublin aquifer system & $18 \mathrm{U} 001$ & Georgia Kraft, USGS, test well 3 & 81 \\
\hline Walker & Paleozoic rock & 03PP01 & National Park Service, Chickamauga Battlefield Park & 87 \\
\hline Washington & Dublin-Midville aquifer system & $23 \times 027$ & City of Sandersville, well 8 & 85 \\
\hline Wayne & Upper Floridan & 30L003 & City of Jesup Housing Authority & 48 \\
\hline Wayne & Upper Floridan & $32 \mathrm{~L} 015$ & GGS, Gardi, test well 1 & 49 \\
\hline Wayne & upper Brunswick & 32L016 & GGS, Gardi, test well 2 & 21 \\
\hline Wayne & surficial & $32 \mathrm{~L} 017$ & GGS, Gardi, test well 3 & 18 \\
\hline White & crystalline rock & 16MM03 & Unicoi State Park, well 4 & 93 \\
\hline Worth & Claiborne & $13 \mathrm{M} 005$ & USGS, test well DP-7 & 67 \\
\hline Worth & surficial & 13M007 & USGS, test well DP-9 & 12 \\
\hline Worth & Upper Floridan & $15 \mathrm{~L} 020$ & City of Sylvester & 33 \\
\hline
\end{tabular}




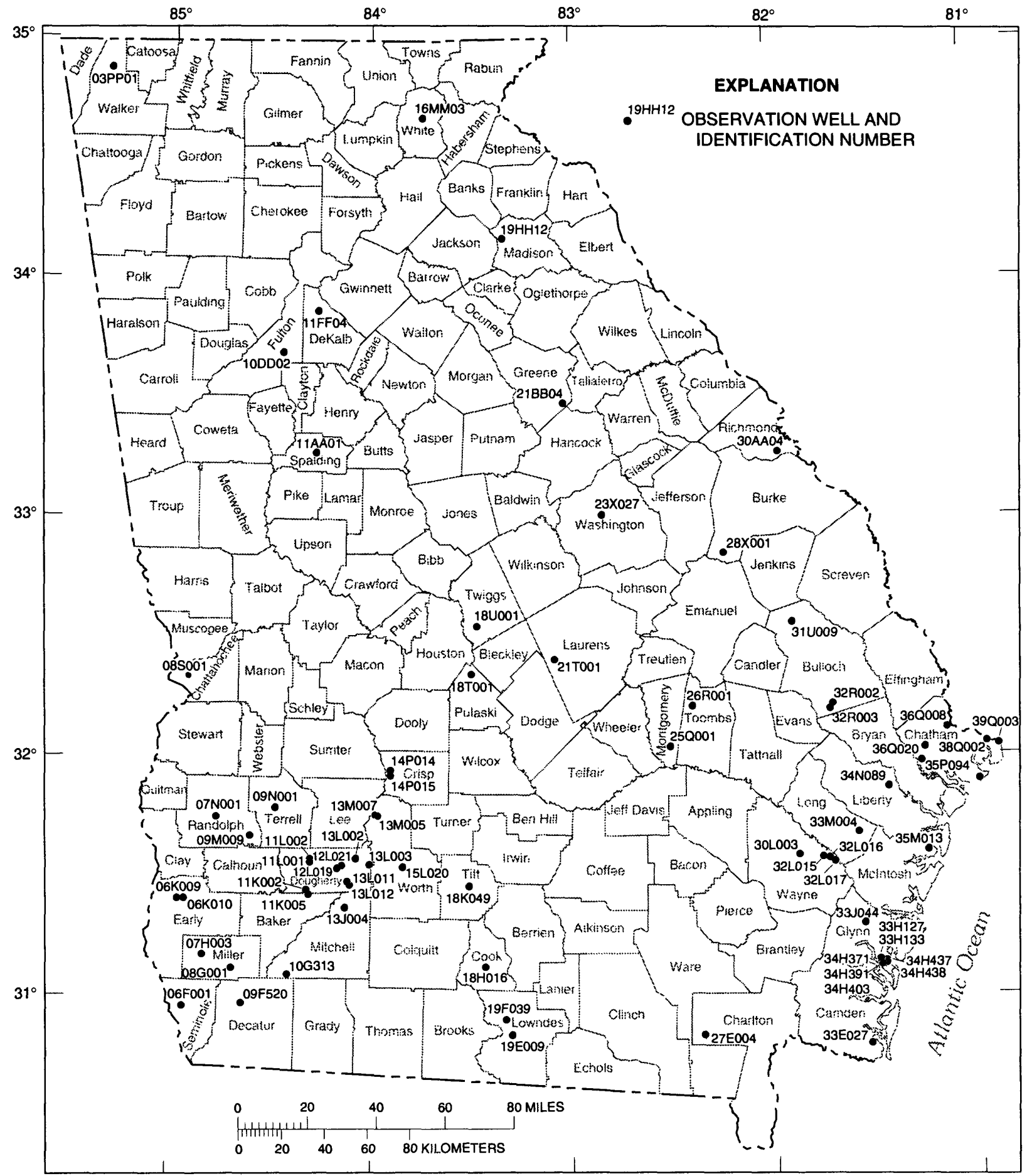

Base modified from U.S.Geological Survey State base map

Figure 2.-Locations of observation wells for which hydrographs are included in this report. 


\section{Surficial Aquifers}

Water-level fluctuations in surficial aquifers were monitored in 15 wells in 1995 and data from eight of these wells (fig. 3 ) are summarized in this report. Water-level fluctuations in surficial aquifers mainly were caused by variations in precipitation, evapotranspiration, and natural drainage. Water levels in surficial aquifers generally rise rapidly during wet periods and decline slowly during dry periods. Prolonged droughts may cause water levels to decline below pump intakes in shallow wells, particularly those located on hilltops and steep slopes, resulting in temporary well failures. Usually, well yields are restored with an increase in precipitation.

\section{Northern area}

Water levels in the surficial aquifers in the northern part of Georgia were monitored in two wells in 1995. Data for one of these wells, 11AA01, at Griffin, Spalding County, is shown in figure 4. The annual mean water level in well 11AA01 was $1.4 \mathrm{ft}$ lower in 1995 than in 1994.

\section{Southwestern area}

Water levels were monitored in seven wells that tap the surficial aquifer in the southwestern area in 1995. Data for two of the wells are shown in figures 5 and 6. The 1995 mean water levels in well 13M007 (fig. 5) in Worth County and well $07 \mathrm{H003}$ (fig. 6) in Miller County were 2.1 and $4.6 \mathrm{ft}$ lower than in 1994, respectively.

\section{Coastal area}

Water levels in surficial aquifers in the coastal area were monitored in six wells in 1995 and data for five of the wells are shown in figures 7-11. Water levels in surficial aquifers in the northern part of the coastal area are affected by variations in precipitation, evapotranspiration, and natural drainage (Clarke and others, 1990, p. 22). The annual mean water level in well 35P094 (fig. 7) was $1.7 \mathrm{ft}$ higher in 1995 than in 1994. In 1995, the annual mean water levels in wells 37P116 (fig. 8) and 32R003 (fig. 9) were $0.2 \mathrm{ft} \mathrm{higher}$ and the same as in 1994, respectively.

The water-level in the surficial aquifer in the Brunswick area is influenced by nearby pumping, precipitation, and tidal fluctuations (Clarke and others, 1990, p. 24). The annual mean water level in well $34 \mathrm{H} 438$ (fig. 10) in Glynn County was the same in 1995 as in 1994. In 1995, the annual mean water level in well 32L017 (fig. 11) in the Jesup, Wayne County area, was $0.6 \mathrm{ft}$ higher in 1995 than in 1994. 


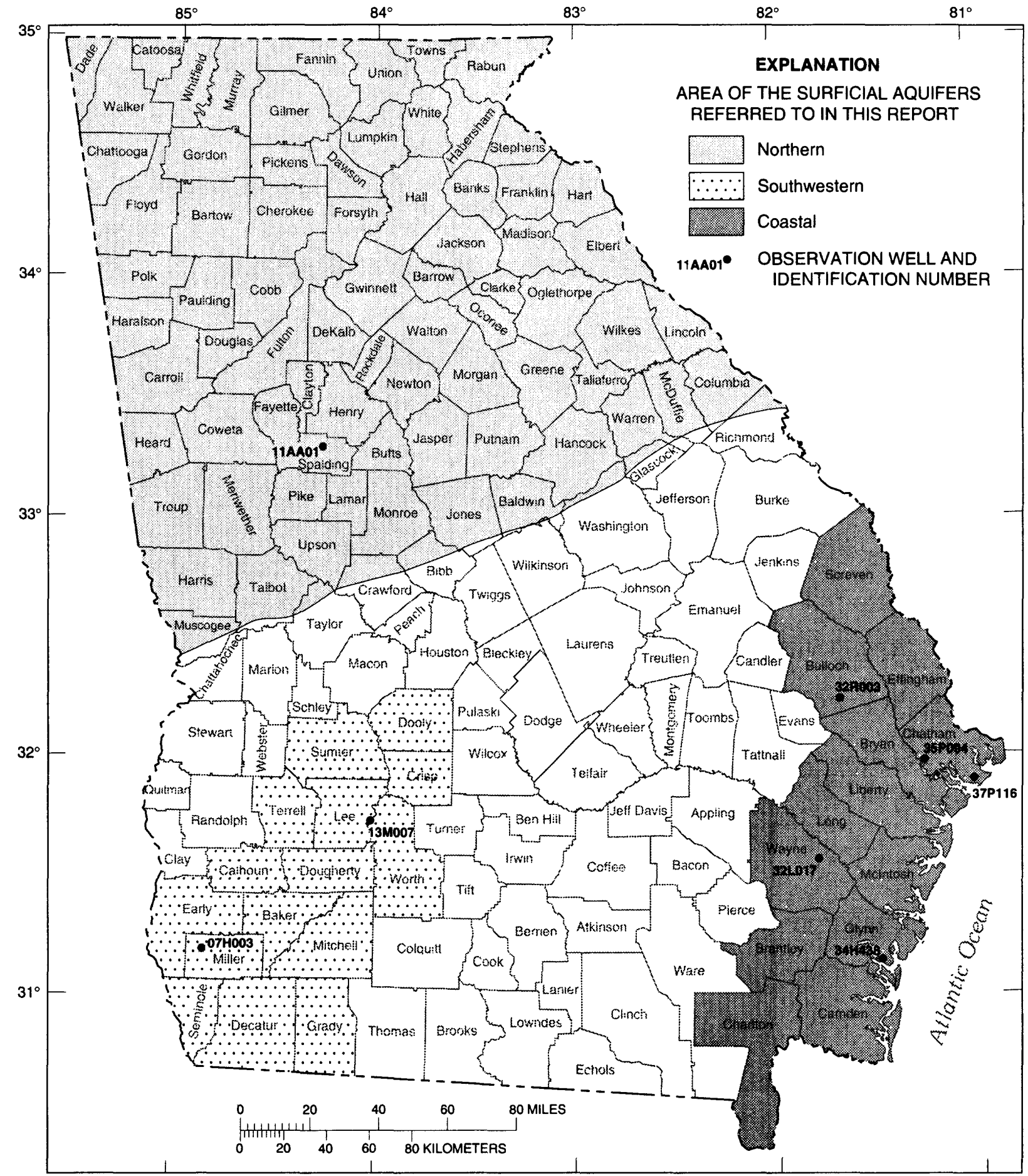

Base modified from U.S.Geological Survey State base map

Figure 3.-Locations of observation wells completed in the surficial aquifers. 
331507084171801 Local number, 11 AA01.

LOCATION. - Lat $33^{\circ} 15^{\prime} 54^{\prime \prime}$, long $84^{\circ} 16^{\prime} 56^{\prime \prime}$, Hydrologic Unit 03070103.

SITE NAME.-University of Georgia, Experiment Station.

INSTRUMENTATION.-Digital recorder.

AQUIFER.-Surficial (residuum).

WELL CHARACTERISTICS. - Dug unused supply well, size $4 \times 4 \mathrm{ft}$, depth $30 \mathrm{ft}$, cased to $30 \mathrm{ft}$, open end.

DATUM.-Altitude of land-surface datum is $950 \mathrm{ft}$.

REMARKS.-None.

PERIOD OF RECORD.-October 1943 to current year. Continuous record since October 1943.

EXTREMES FOR PERIOD OF RECORD. - Highest water level, $8.26 \mathrm{ft}$ below land-surface datum, March 19, 1948; lowest, $21.82 \mathrm{ft}$ below land-surface datum, November 18-19, 1986.

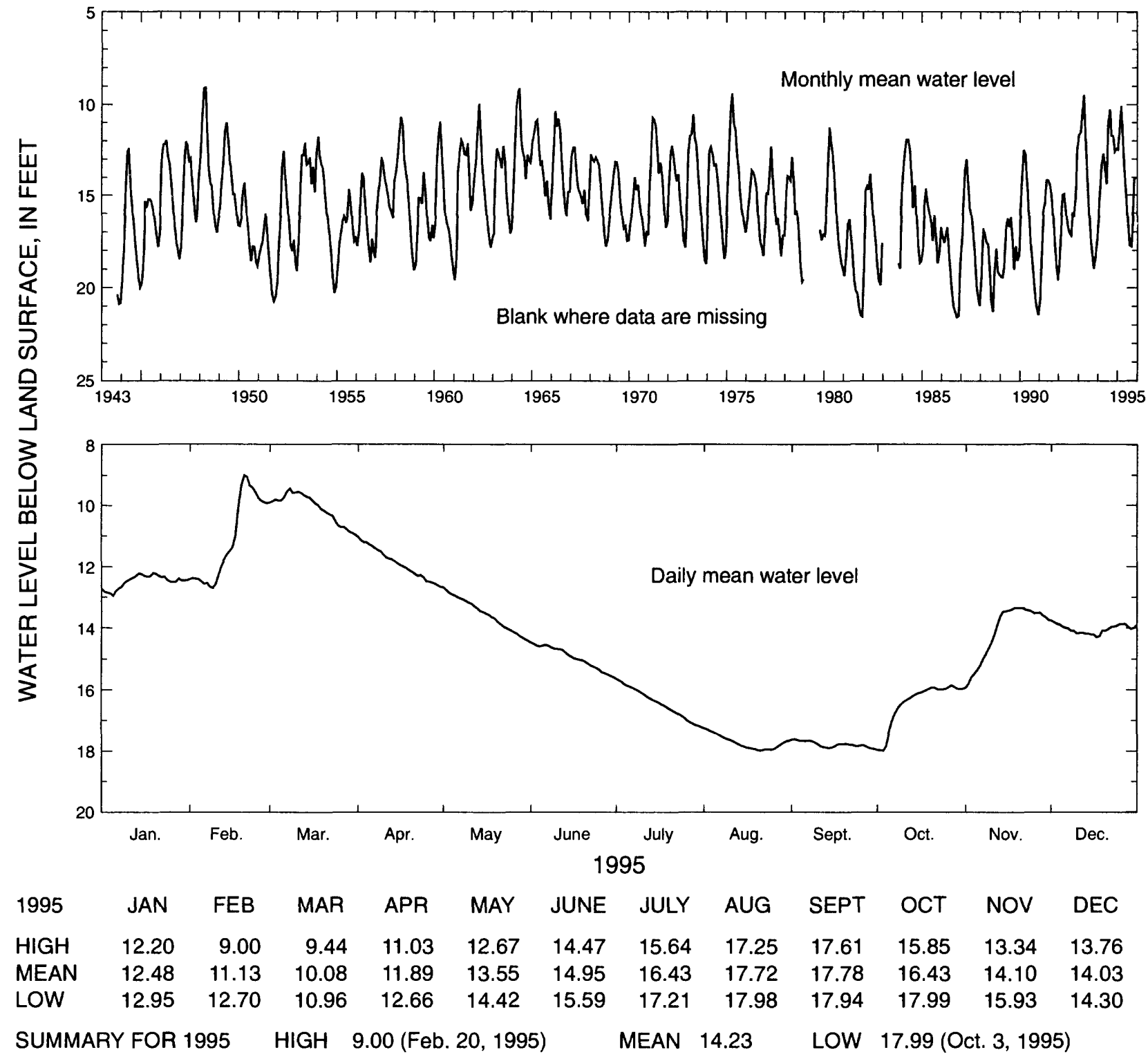

Figure 4.-Water level in observation well 11AA01, Spalding County. 
314330084005403 Local number, $13 \mathrm{M} 007$.

LOCATION.-Lat $31^{\circ} 43^{\prime} 30^{\prime \prime}$, long $84^{\circ} 00^{\prime} 54^{\prime \prime}$, Hydrologic Unit 03130006.

SITE NAME.-U.S. Geological Survey, test well DP-9.

INSTRUMENTATION.-Digital recorder.

AQUIFER.-Surficial (residuum).

WELL CHARACTERISTICS.-Drilled observation well, diameter 4 in., depth $25 \mathrm{ft}$, cased to $10 \mathrm{ft}$, open hole.

DATUM.-Altitude of land-surface datum is $230 \mathrm{ft}$.

REMARKS.-None.

PERIOD OF RECORD.-April 1980 to current year. Continuous record since April 1980.

EXTREMES FOR PERIOD OF RECORD.-Highest water level, $3.48 \mathrm{ft}$ below land-surface datum, March 7, 1984; lowest, $13.03 \mathrm{ft}$ below land-surface datum, October 22, 1981.
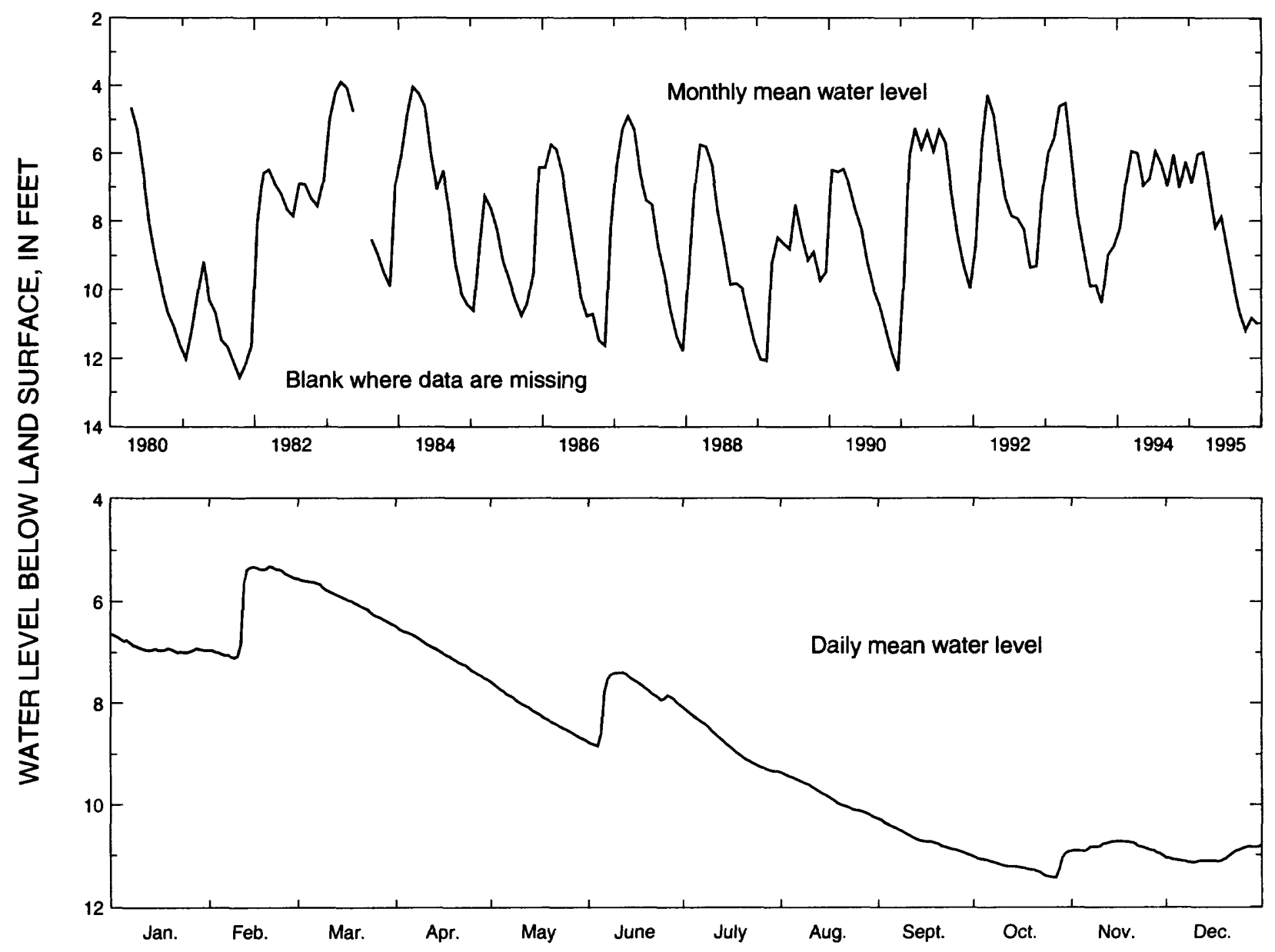

$\begin{array}{lcccccccccccr}1995 & \text { JAN } & \text { FEB } & \text { MAR } & \text { APR } & \text { MAY } & \text { JUNE } & \text { JULY } & \text { AUG } & \text { SEPT } & \text { OCT } & \text { NOV } & \text { DEC } \\ \text { HIGH } & 6.64 & 5.32 & 5.56 & 6.49 & 7.58 & 7.40 & 8.09 & 9.35 & 10.28 & 10.93 & 10.73 & 10.81 \\ \text { MEAN } & 6.90 & 6.04 & 5.97 & 7.00 & 8.19 & 7.87 & 8.81 & 9.82 & 10.68 & 11.21 & 10.84 & 11.02 \\ \text { LOW } & 7.00 & 7.10 & 6.46 & 7.54 & 8.73 & 8.84 & 9.33 & 10.26 & 11.00 & 11.44 & 11.01 & 11.14 \\ \text { SUMMARY FOR 1995 } & \text { HIGH } & 5.32 \text { (Feb. 20, 1995) } & \text { MEAN } & 8.71 & \text { LOW } & 11.44 \text { (Oct. 27, 1995) }\end{array}$

Figure 5.-Water level in observation well 13M007, Worth County. 
311009084495503 Local number, $07 \mathrm{H} 003$.

LOCATION.-Lat $31^{\circ} 10^{\prime} 08^{\prime \prime}$, long $84^{\circ} 49^{\prime} 54^{\prime \prime}$, Hydrologic Unit 03130010.

SITE NAME. -U.S. Geological Survey, test well DP-3.

INSTRUMENTATION.-Digital recorder.

AQUIFER.-Surficial (residuum).

WELL CHARACTERISTICS.-Drilled observation well, diameter 4 in., depth $40 \mathrm{ft}$, perforated casing 30 to $40 \mathrm{ft}$.

DATUM.-Altitude of land-surface datum is $180 \mathrm{ft}$.

REMARKS. - Water levels for period, January 9-10, are missing.

PERIOD OF RECORD.-February 1980 to current year. Continuous record since February 1980.

EXTREMES FOR PERIOD OF RECORD. - Highest water level, $0.25 \mathrm{ft}$ below land-surface datum, January 30, 1991; lowest, $24.19 \mathrm{ft}$ below land-surface datum, November 10, 1981.

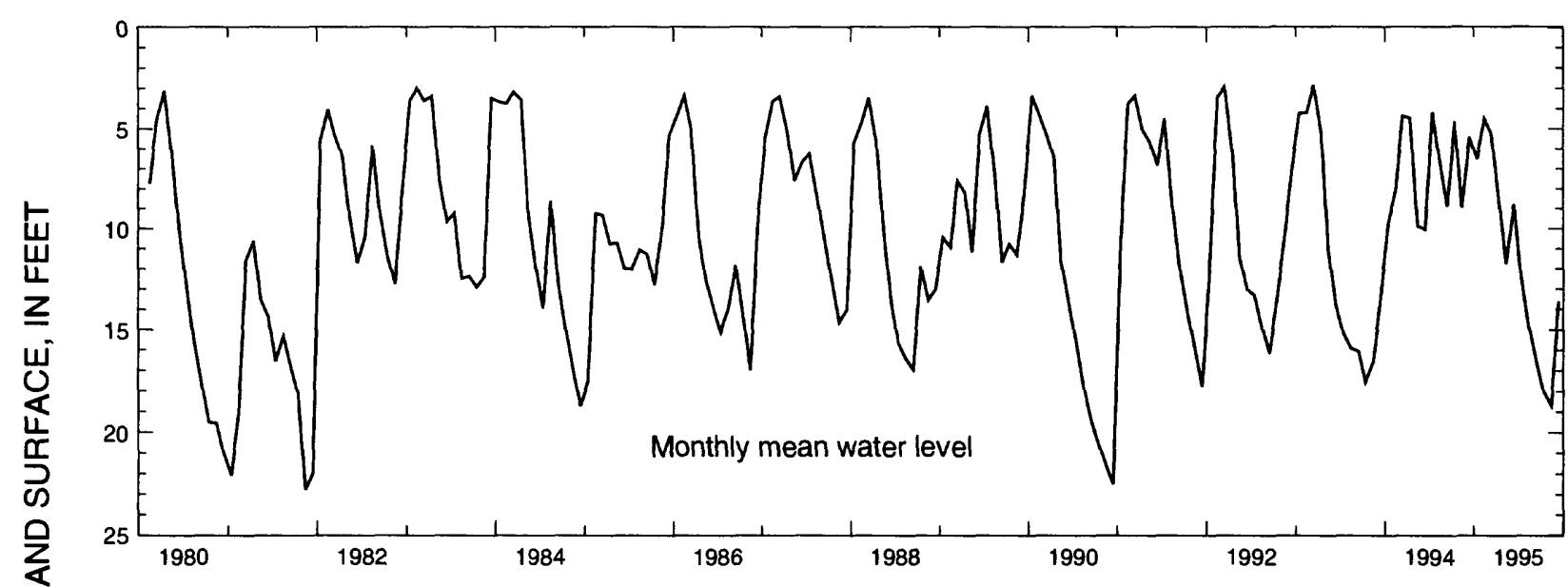

$\begin{array}{lrrrrrrrrrrrr}1995 & \text { JAN } & \text { FEB } & \text { MAR } & \text { APR } & \text { MAY } & \text { JUNE } & \text { JULY } & \text { AUG } & \text { SEPT } & \text { OCT } & \text { NOV } & \text { DEC } \\ \text { HIGH } & 4.41 & 1.61 & 3.23 & 6.92 & 10.69 & 3.96 & 11.02 & 13.83 & 15.68 & 17.38 & 18.27 & 10.71 \\ \text { MEAN } & 6.49 & 4.48 & 5.23 & 8.55 & 11.74 & 8.78 & 12.39 & 14.77 & 16.50 & 18.00 & 18.68 & 13.59 \\ \text { LOW } & 7.91 & 6.99 & 7.21 & 10.56 & 12.66 & 12.96 & 13.76 & 15.61 & 17.31 & 18.71 & 18.98 & 19.11 \\ \text { SUMMARY FOR 1995 } & \text { HIGH } & 1.61 \text { (Feb. 12, 1995) } & \text { MEAN } & 11.67 & \text { LOW } & 19.11 \text { (Dec. 6, 1995) }\end{array}$

Figure 6. -Water level in observation well 07H003, Miller County. 
315950081161201 Local number, 35P094.

LOCATION.-Lat $31^{\circ} 59^{\prime} 50^{\prime \prime}$, long 81 ${ }^{\circ} 16^{\prime} 12^{\prime \prime}$, Hydrologic Unit 03060204.

SITE NAME. -University of Georgia, Bamboo Farm.

INSTRUMENTATION.-Digital recorder.

AQUIFER.-Surficial (sand of Holocene and Pleistocene age).

WELL CHARACTERISTICS. - Bored observation well, diameter 30 in., depth $15 \mathrm{ft}$, cased to $15 \mathrm{ft}$, open end.

DATUM.-Altitude of land-surface datum is $18.67 \mathrm{ft}$.

REMARKS.-Responds quickly to precipitation. Water levels for periods, February 7-23 and July 2-24, are missing. PERIOD OF RECORD.-August 1942 to current year. Continuous record since August 1942.

EXTREMES FOR PERIOD OF RECORD.- Highest water level, $0.05 \mathrm{ft}$ below land-surface datum, September 26 , 1953; lowest, $12.28 \mathrm{ft}$ below land-surface datum, November 30, 1972.

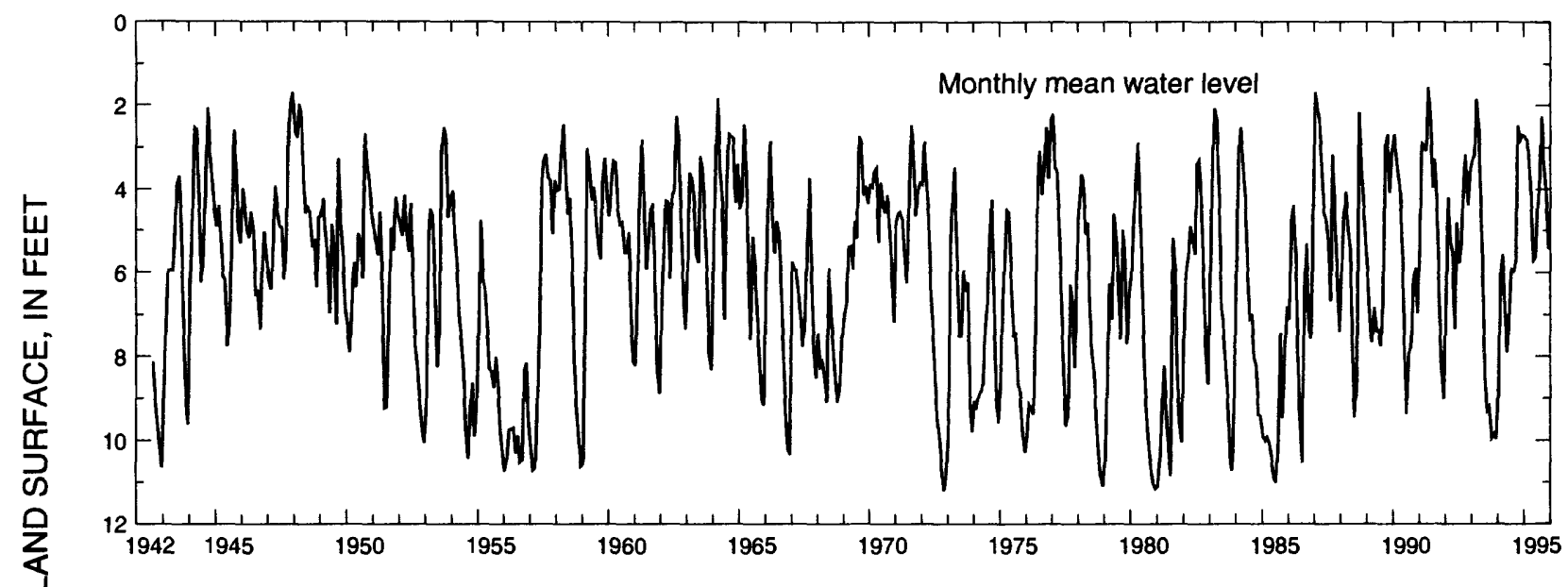

\begin{tabular}{|c|c|c|c|c|c|c|c|c|c|c|c|c|}
\hline 1995 & JAN & FEB & MAR & APR & MAY & JUNE & JULY & AUG & SEPT & OCT & NOV & DEC \\
\hline HIG & 1.50 & --.-. & 2.34 & 3.65 & 4.65 & 4.63 & ----.- & 0.17 & 0.99 & 2.94 & 3.53 & 4.91 \\
\hline MEAN & 2.73 & --.-- & 3.06 & 4.14 & 5.71 & 5.63 & & 3.76 & 2. & 3.35 & 4.19 & .44 \\
\hline LOW & 3.18 & --.-- & 3.69 & 4.83 & 6.55 & 6.64 & 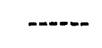 & 4.95 & 3.01 & 3.84 & 4.87 & 5.91 \\
\hline \multicolumn{3}{|c|}{ SUMMARY FOR 1995} & \multicolumn{4}{|c|}{ HIGH 0.17 (Aug. 26, 1995) } & \multicolumn{2}{|c|}{ MEAN 4.00} & \multicolumn{4}{|c|}{ LOW 6.64 (June 3, 1995) } \\
\hline
\end{tabular}

Figure 7.-Water level in observation well 35P094, Chatham County. 
315906081011204 Local number, 37P116.

LOCATION.-Lat $31^{\circ} 59^{\prime} 06^{\prime \prime}$, long 81 ${ }^{\circ} 01^{\prime} 12^{\prime \prime}$, Hydrologic Unit 03060204.

SITE NAME.-Georgia Geologic Survey, Skidaway Institute, test well 4.

INSTRUMENTATION.-Digital recorder.

AQUIFER.-Surficial (sand of Miocene and post-Miocene age).

WELL CHARACTERISTICS.-Drilled observation well, diameter 6 in., depth $85 \mathrm{ft}$, cased to $70 \mathrm{ft}$, screen to $85 \mathrm{ft}$. DATUM.-Altitude of land-surface datum is $10 \mathrm{ft}$.

REMARKS.-None.

PERIOD OF RECORD. January 1984 to current year. Continuous record since January 1984.

EXTREMES FOR PERIOD OF RECORD.-Highest water level, $6.93 \mathrm{ft}$ below land-surface datum, October 13-14, 1994; lowest, $9.27 \mathrm{ft}$ below land-surface datum, March 17, 1993.

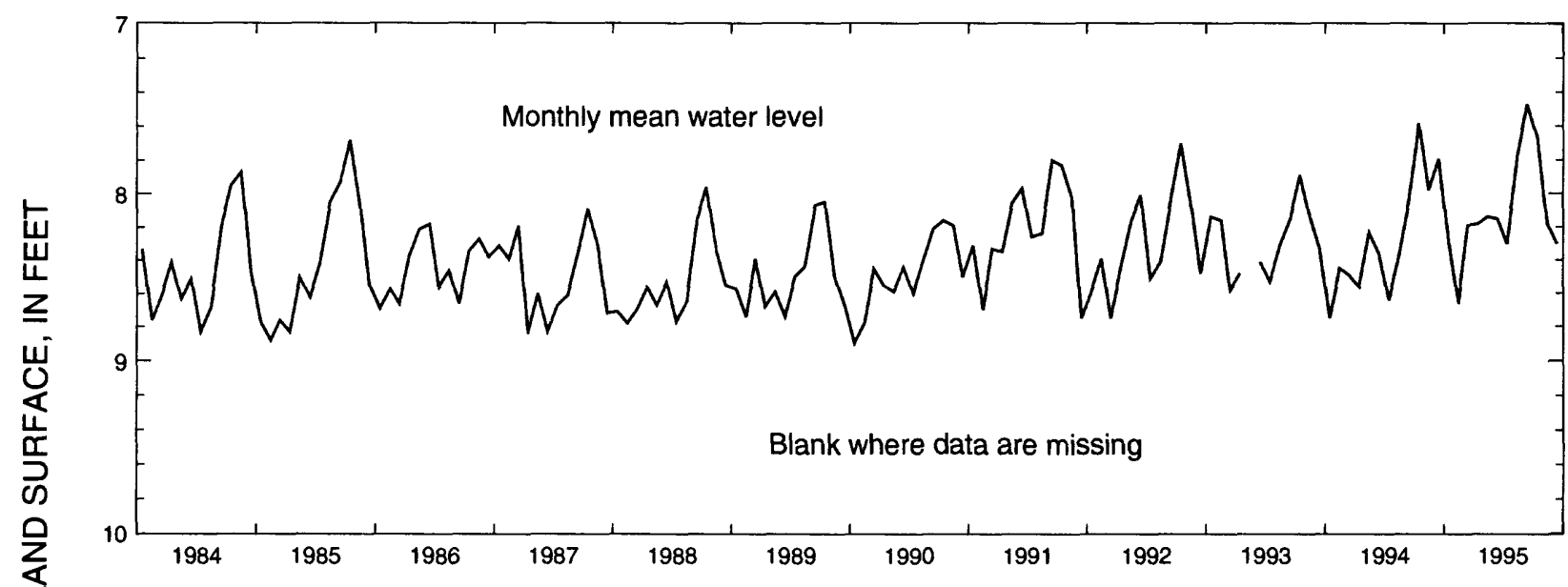

岁

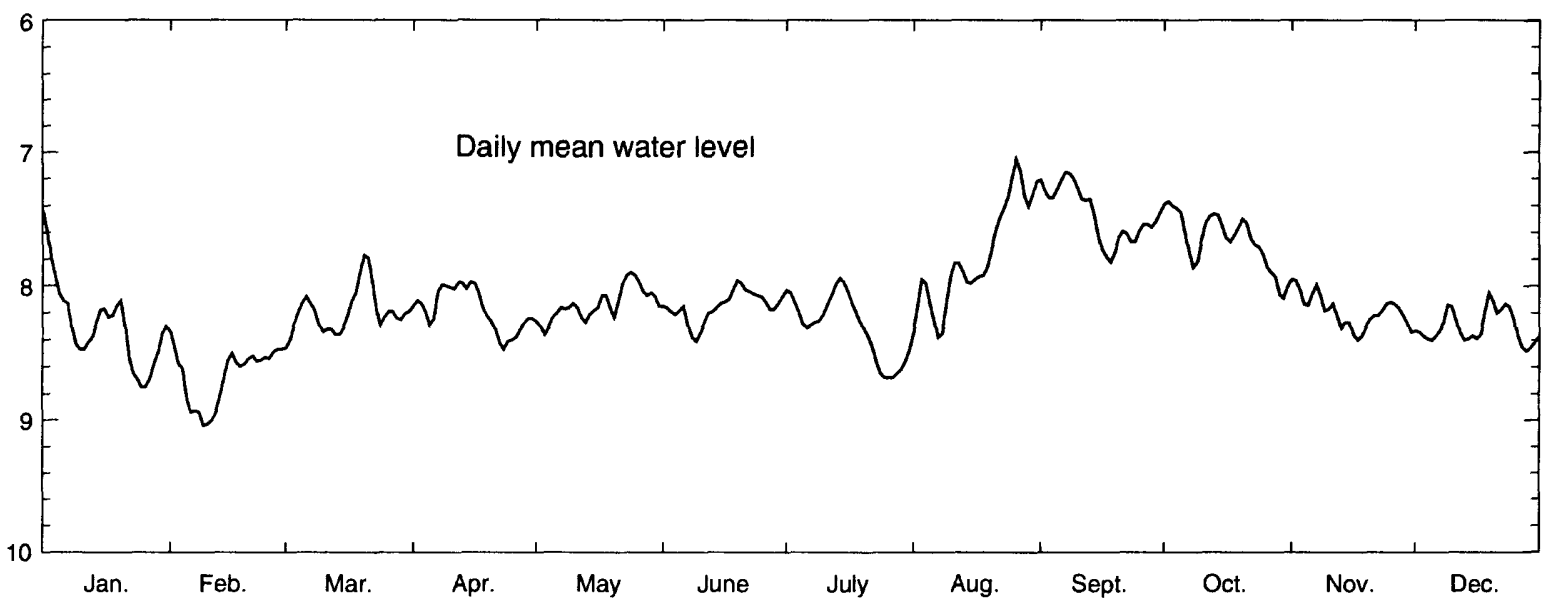

1995

$\begin{array}{lllllllllllll}1995 & \text { JAN } & \text { FEB } & \text { MAR } & \text { APR } & \text { MAY } & \text { JUNE } & \text { JULY } & \text { AUG } & \text { SEPT } & \text { OCT } & \text { NOV } & \text { DEC } \\ \text { HIGH } & 7.43 & 8.34 & 7.77 & 7.97 & 7.90 & 7.96 & 7.94 & 7.05 & 7.15 & 7.37 & 7.95 & 8.05 \\ \text { MEAN } & 8.29 & 8.66 & 8.19 & 8.18 & 8.14 & 8.15 & 8.30 & 7.77 & 7.47 & 7.66 & 8.18 & 8.30 \\ \text { LOW } & 8.75 & 9.04 & 8.46 & 8.47 & 8.36 & 8.41 & 8.68 & 8.38 & 7.82 & 8.09 & 8.40 & 8.48\end{array}$

SUMMARY FOR 1995 HIGH 7.05 (Aug. 26, 1995) MEAN 8.10 LOW 9.04 (Feb. 9, 1995)

Figure 8.-Water level in observation well 37P116, Chatham County. 
321240081411502 Local number, 32R003.

LOCATION.-Lat $32^{\circ} 12^{\prime} 40^{\prime \prime}$, long 81 ${ }^{\circ} 41^{\prime} 15^{\prime \prime}$, Hydrologic Unit 03060202.

SITE NAME.-Georgia Geologic Survey, Bulloch South, test well 2.

INSTRUMENTATION.-Digital recorder.

AQUIFER.-Surficial (sand of Miocene and post Miocene age).

WELL CHARACTERISTICS. - Drilled observation well, diameter 6 in., depth $155 \mathrm{ft}$, cased to $134 \mathrm{ft}$, screen to $155 \mathrm{ft}$.

DATUM.-Altitude of land-surface datum is $120 \mathrm{ft}$.

REMARKS.-None.

PERIOD OF RECORD.-February 1983 to current year. Continuous record since February 1983.

EXTREMES FOR PERIOD OF RECORD. - Highest water level, $8.28 \mathrm{ft}$ below land-surface datum, March 6, 1993;

lowest, $15.27 \mathrm{ft}$ below land-surface datum, November 14, 1983.
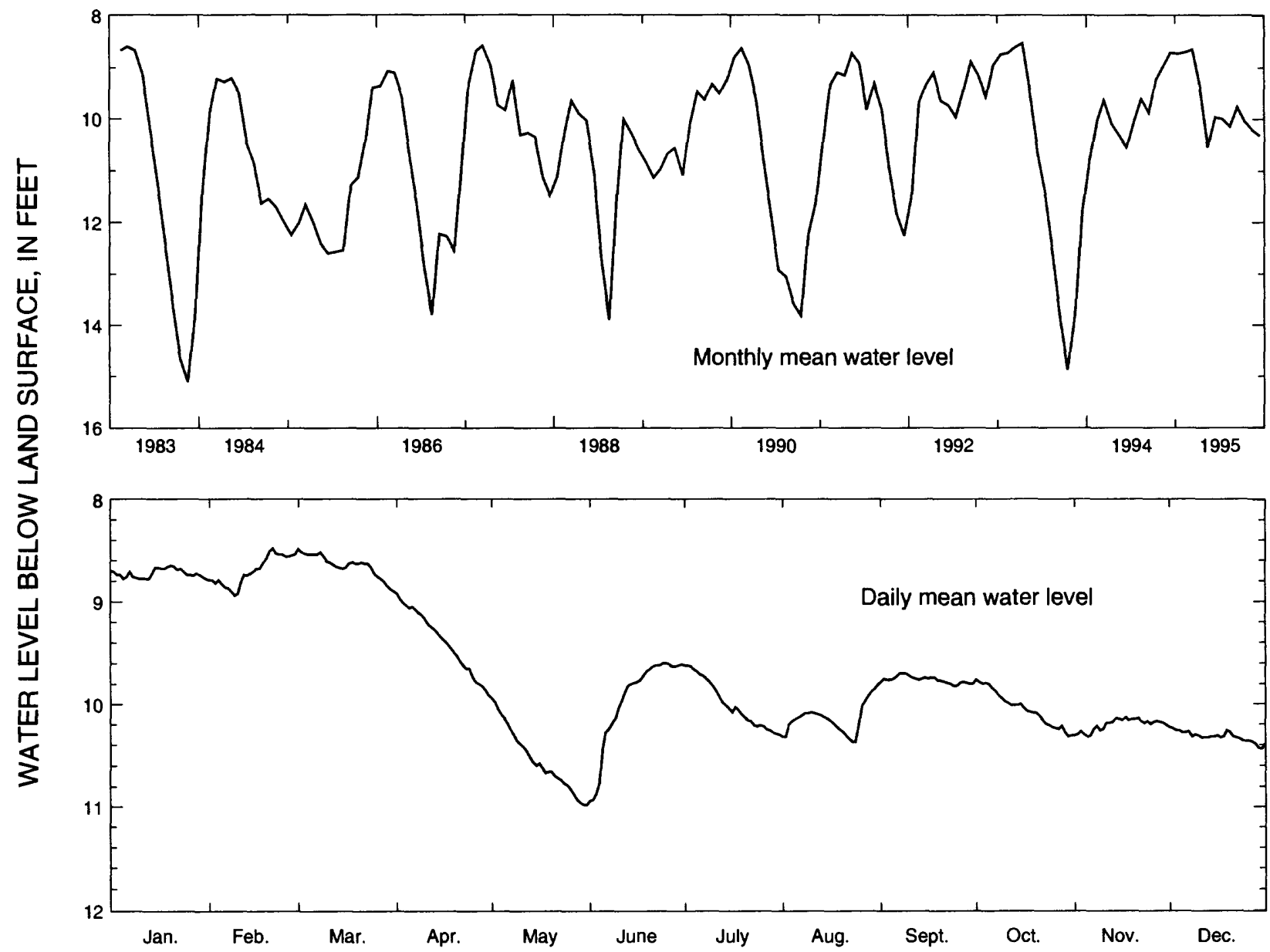

$\begin{array}{lllllrrrrrrrr}1995 & \text { JAN } & \text { FEB } & \text { MAR } & \text { APR } & \text { MAY } & \text { JUNE } & \text { JULY } & \text { AUG } & \text { SEPT } & \text { OCT } & \text { NOV } & \text { DEC } \\ \text { HIGH } & 8.65 & 8.48 & 8.49 & 8.92 & 9.94 & 9.60 & 9.62 & 9.81 & 9.70 & 9.76 & 10.13 & 10.23 \\ \text { MEAN } & 8.73 & 8.70 & 8.65 & 9.39 & 10.54 & 9.96 & 9.99 & 10.14 & 9.76 & 10.04 & 10.21 & 10.32 \\ \text { LOW } & 8.78 & 8.94 & 8.90 & 9.91 & 10.98 & 10.94 & 10.30 & 10.37 & 9.82 & 10.32 & 10.32 & 10.44\end{array}$

SUMMARY FOR 1995 HIGH 8.48 (Feb. 21, 1995) MEAN 9.71 LOW 10.98 (May 30-31, 1995)

Figure 9.-Water level in observation well 32R003, Bulloch County. 
310901081284403 Local number, $34 \mathrm{H} 438$.

LOCATION.-Lat $31^{\circ} 09^{\prime} 01^{\prime \prime}$, long $81^{\circ} 28^{\prime} 44^{\prime \prime}$, Hydrologic Unit 03070203.

SITE NAME.-Georgia Geologic Survey, Coffin Park, test well 3.

INSTRUMENTATION.-Electronic data recorder.

AQUIFER.-Surficial (sand of Miocene and post-Miocene age).

WELL CHARACTERISTICS. - Drilled observation well, diameter $6 \mathrm{in}$., depth $202 \mathrm{ft}$, cased to $192 \mathrm{ft}$, screen to $202 \mathrm{ft}$.

DATUM.-Altitude of land-surface datum is $7 \mathrm{ft}$.

REMARKS.-None.

PERIOD OF RECORD.-November 1983 to current year. Continuous record November 1983 to September 1984, and since January 1985.

EXTREMES FOR PERIOD OF RECORD. - Highest water level, $1.54 \mathrm{ft}$ below land-surface datum, October 16, 1994; lowest, $8.13 \mathrm{ft}$ below land-surface datum, July 12, 1990.
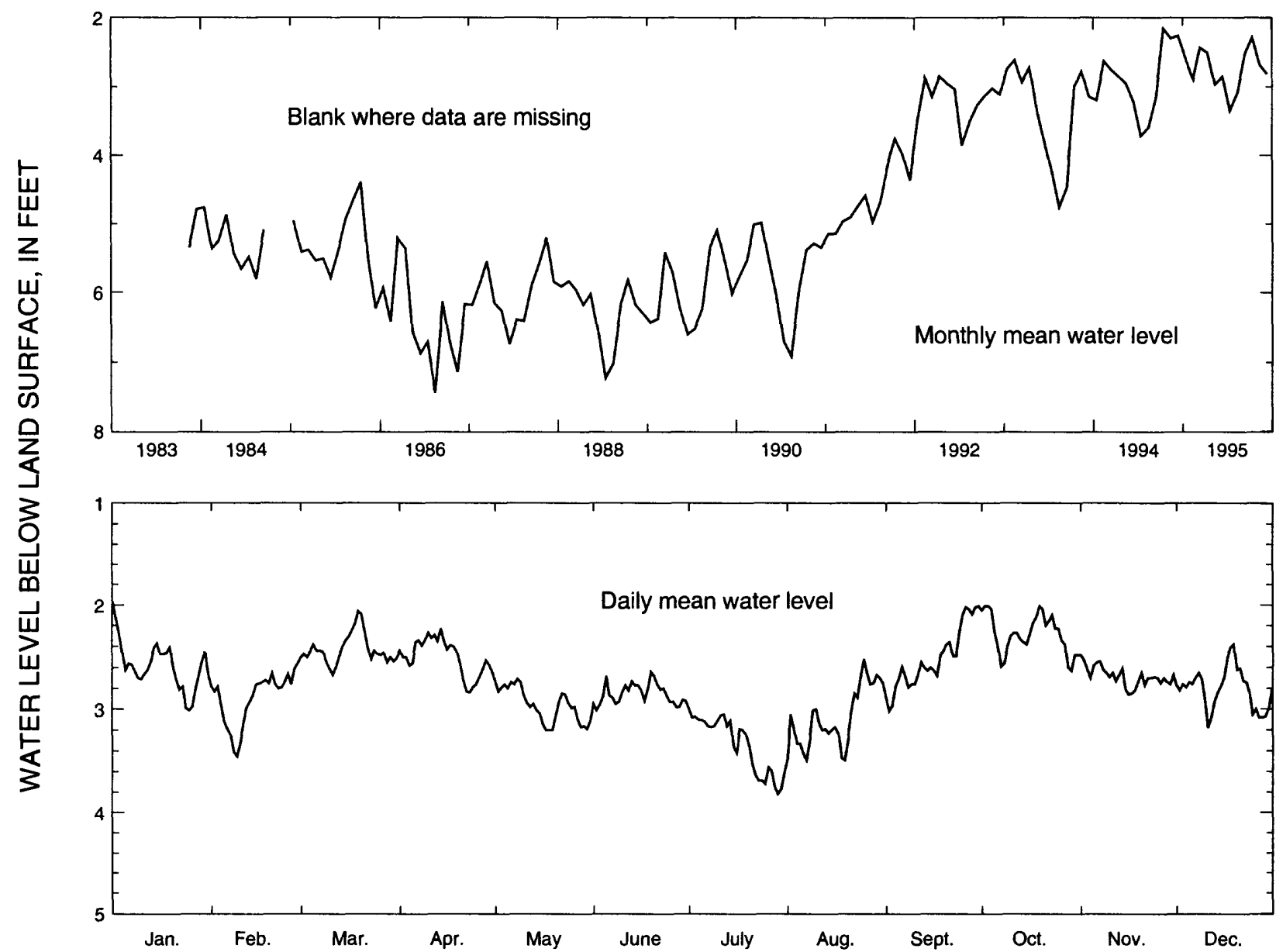

1995

$\begin{array}{lllllllllllll}1995 & \text { JAN } & \text { FEB } & \text { MAR } & \text { APR } & \text { MAY } & \text { JUNE } & \text { JULY } & \text { AUG } & \text { SEPT } & \text { OCT } & \text { NOV } & \text { DEC } \\ \text { HIGH } & 1.97 & 2.56 & 2.06 & 2.23 & 2.71 & 2.64 & 3.00 & 2.52 & 2.01 & 2.01 & 2.48 & 2.38 \\ \text { MEAN } & 2.58 & 2.89 & 2.43 & 2.50 & 2.96 & 2.85 & 3.34 & 3.08 & 2.52 & 2.28 & 2.68 & 2.81 \\ \text { LOW } & 3.01 & 3.45 & 2.67 & 2.84 & 3.20 & 3.01 & 3.82 & 3.49 & 3.02 & 2.63 & 2.86 & 3.18\end{array}$

SUMMARY FOR 1995 HIGH 1.97 (Jan. 1, 1995) MEAN 2.74 LOW $3.82($ July 29, 1995)

Figure 10.-Water level in observation well 34H438, Glynn County. 
313253081433504 Local number, 32L017.

LOCATION.-Lat $31^{\circ} 32^{\prime} 52^{\prime \prime}$, long $81^{\circ} 43^{\prime} 36^{\prime \prime}$, Hydrologic Unit 03070106.

SITE NAME.-Georgia Geologic Survey, Gardi, test well 3.

INSTRUMENTATION.-Digital recorder.

AQUIFER.-Surficial (sand of Miocene and post-Miocene age).

WELL CHARACTERISTICS.-Drilled observation well, diameter 4 in., depth $215 \mathrm{ft}$, cased to $200 \mathrm{ft}$, screen to $215 \mathrm{ft}$.

DATUM.-Altitude of land-surface datum is $74 \mathrm{ft}$.

REMARKS.-None.

PERIOD OF RECORD.-June 1983 to current year. Continuous record since June 1983.

EXTREMES FOR PERIOD OF RECORD.-Highest water level, $37.85 \mathrm{ft}$ below land-surface datum, April 16, 1984; lowest, $43.91 \mathrm{ft}$ below land-surface datum, October $8,1990$.
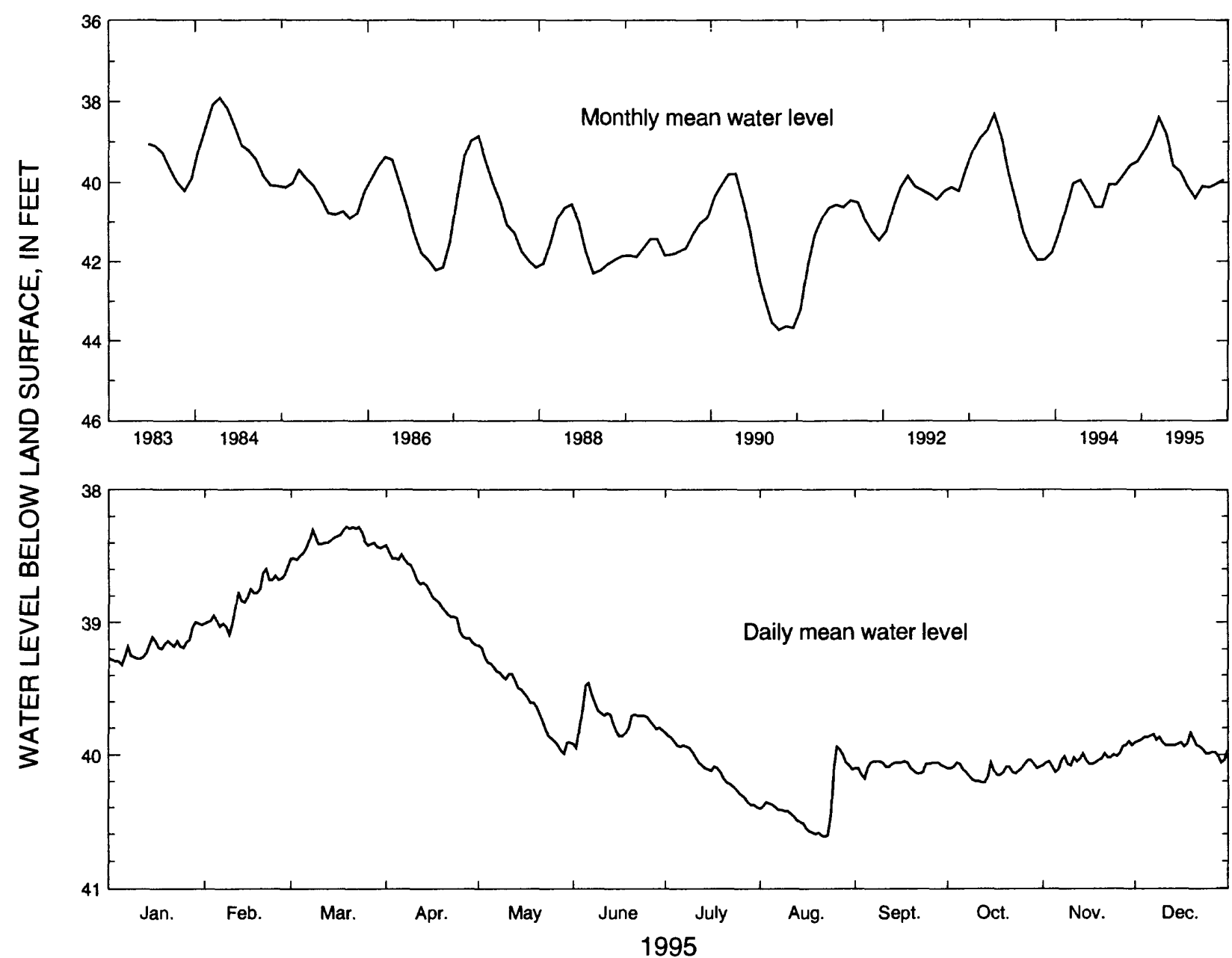

$\begin{array}{lllllllllllll}1995 & \text { JAN } & \text { FEB } & \text { MAR } & \text { APR } & \text { MAY } & \text { JUNE } & \text { JULY } & \text { AUG } & \text { SEPT } & \text { OCT } & \text { NOV } & \text { DEC } \\ \text { HIGH } & 39.00 & 38.58 & 38.28 & 38.42 & 39.17 & 39.46 & 39.84 & 39.94 & 40.05 & 40.04 & 39.90 & 39.84 \\ \text { MEAN } & 39.19 & 38.83 & 38.39 & 38.79 & 39.58 & 39.74 & 40.11 & 40.39 & 40.09 & 40.12 & 40.03 & 39.93 \\ \text { LOW } & 39.32 & 39.09 & 38.53 & 39.17 & 39.99 & 39.95 & 40.40 & 40.62 & 40.18 & 40.21 & 40.13 & 40.06\end{array}$

SUMMARY FOR 1995 HIGH 38.28 (Mar. 19, 21, 23, 1995) MEAN 39.60 LOW 40.62 (Aug. 22, 1995)

Figure 11. - Water level in observation well 32L017, Wayne County. 


\section{Upper Brunswick Aquifer}

The water level in the upper Brunswick aquifer was monitored in five wells in 1995 and data for three of these wells (fig. 12) are summarized in this report. The upper Brunswick aquifer responds to pumping from the Upper Floridan aquifer as a result of the hydraulic connection between the aquifers (Clarke and others, 1990, p. 28). Elsewhere, the water level mainly responds to seasonal variations in recharge and discharge.

The upper Brunswick aquifer in Bulloch County is under unconfined to semiconfined conditions and is influenced by both variations in recharge from precipitation and by pumping from the Upper Floridan aquifer (Clarke and others, 1990, p. 28). The annual mean water level in well 31 U009 (fig. 13) was the same in 1995 as in 1994.

In the Wayne and Glynn County areas, the upper Brunswick aquifer is confined and responds to nearby pumping (Clarke and others, 1990, p. 28). In 1995, the annual mean water level in well 32L016 (fig. 14) near Jesup was the same in 1995 as in 1994 . The annual mean water level in well $34 \mathrm{H} 437$ (fig. 15) near Brunswick was $1.3 \mathrm{ft}$ higher in 1995 than in 1994.

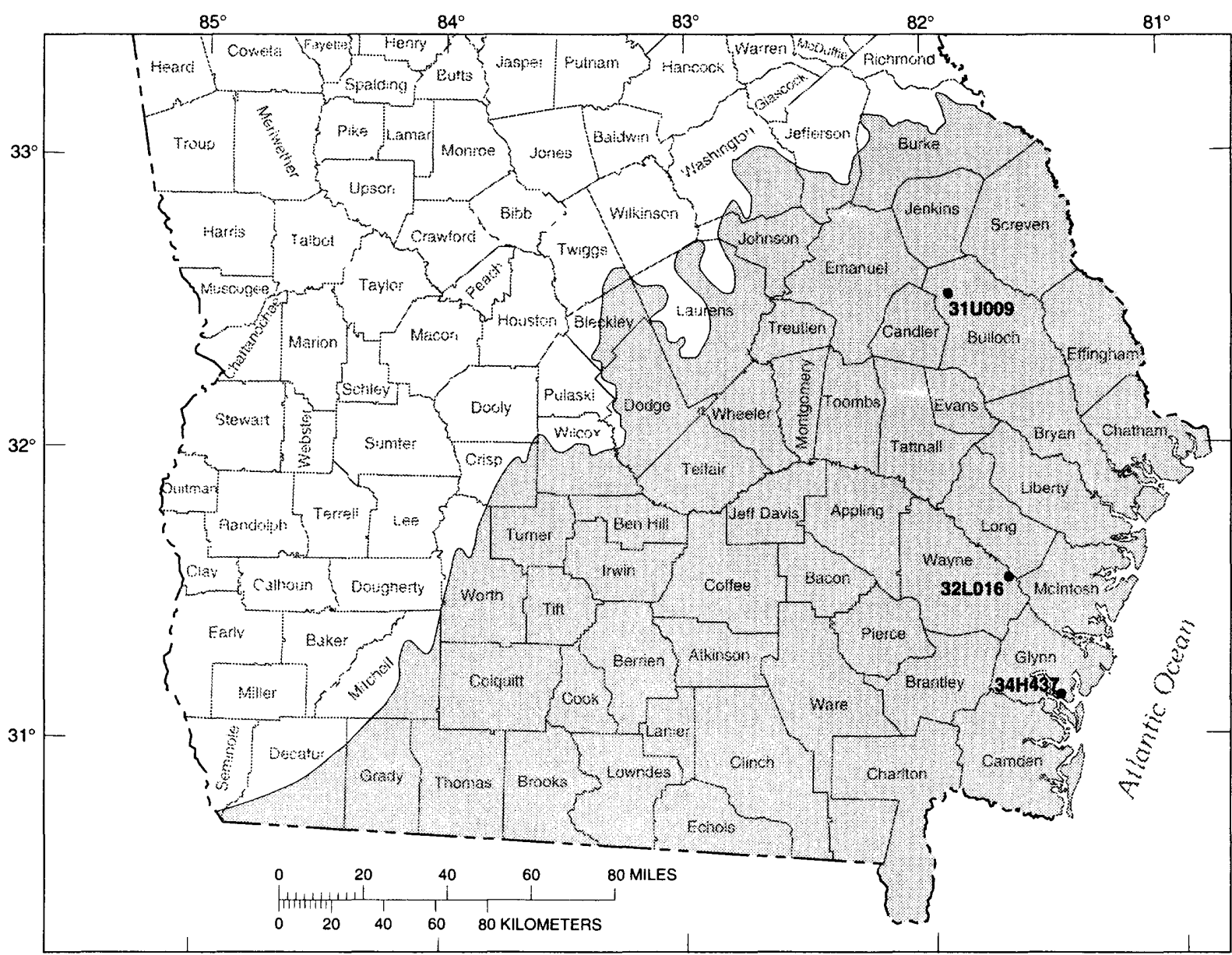

Base modified from U.S.Geological Survey State base map

EXPLANATION

AREA OF MIOCENE DEPOSITS-

(After Mack and Karp, 1984)

Includes the upper Brunswick aquifer $320^{\bullet}$ OBSERVATION WELL AND IDENTIFICATION NUMBER

Figure 12.-Locations of observation wells completed in the upper Brunswick aquifer. (The extent of the upper Brunswick aquifer has not been mapped, but is within the area of Miocene deposits shown.) 
323123081511602 Local number, 31 U009.

LOCATION.-Lat $32^{\circ} 31^{\prime} 23^{\prime \prime}$, long $81^{\circ} 51^{\prime} 16^{\prime \prime}$, Hydrologic Unit 03060202.

SITE NAME.-Georgia Geologic Survey, Hopeulikit, test well 2.

INSTRUMENTATION.-Digital recorder.

AQUIFER.-Upper Brunswick.

WELL CHARACTERISTICS. - Drilled observation well, diameter 6 in., depth $210 \mathrm{ft}$, cased to $160 \mathrm{ft}$, screen to $210 \mathrm{ft}$. DATUM.-Altitude of land-surface datum is $205 \mathrm{ft}$.

REMARKS.-None.

PERIOD OF RECORD.-October 1982 to current year. Continuous record since October 1982.

EXTREMES FOR PERIOD OF RECORD. - Highest water level, $70.77 \mathrm{ft}$ below land-surface datum, April 24, 1983;

lowest, $78.87 \mathrm{ft}$ below land-surface datum, August 4, 1986.
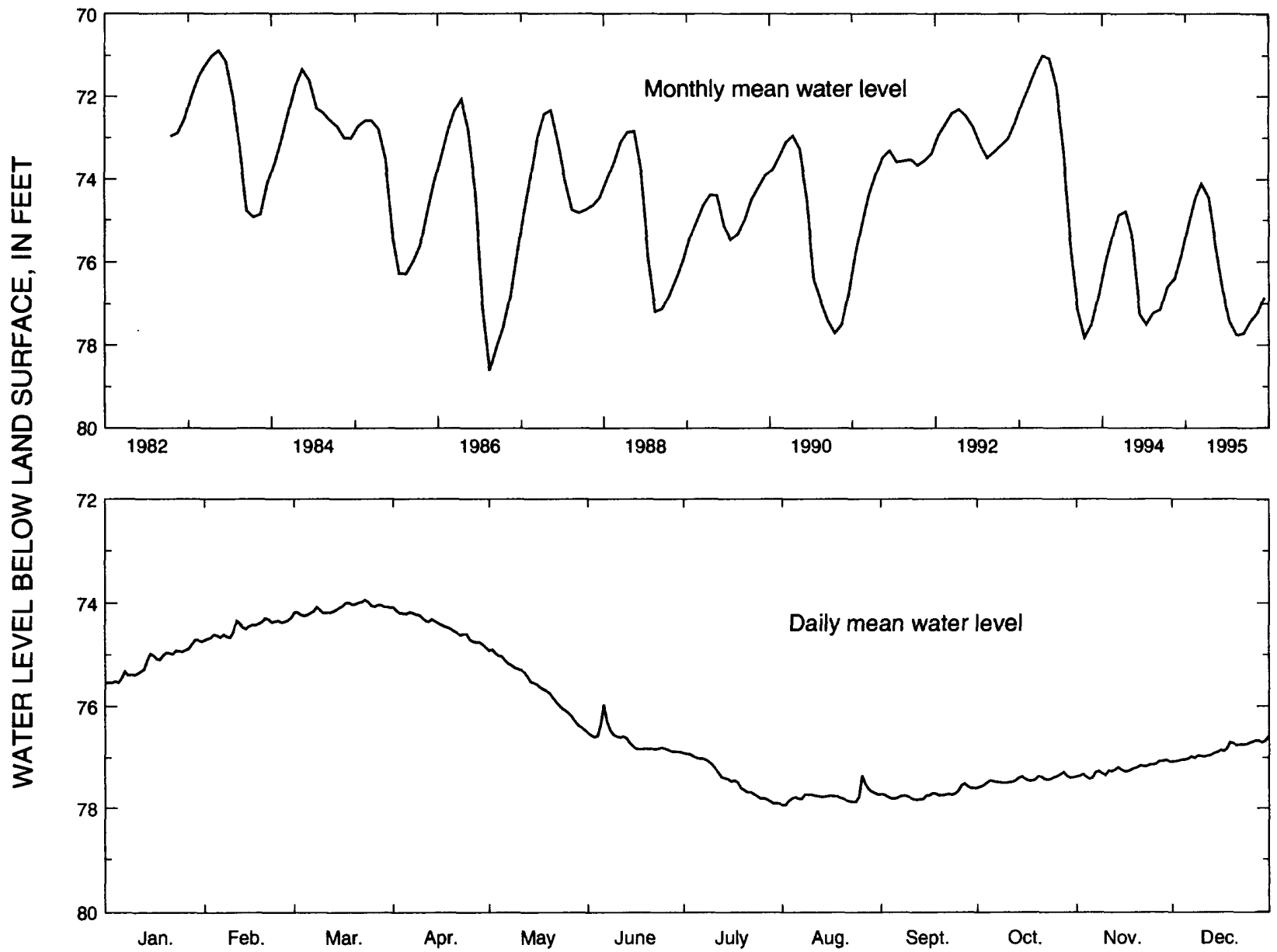

$\begin{array}{lllllllllllll}1995 & \text { JAN } & \text { FEB } & \text { MAR } & \text { APR } & \text { MAY } & \text { JUNE } & \text { JULY } & \text { AUG } & \text { SEPT } & \text { OCT } & \text { NOV } & \text { DEC } \\ \text { HIGH } & 74.72 & 74.28 & 73.94 & 74.09 & 74.90 & 75.96 & 76.91 & 77.35 & 77.51 & 77.29 & 77.05 & 76.58 \\ \text { MEAN } & 75.14 & 74.47 & 74.10 & 74.44 & 75.61 & 76.68 & 77.43 & 77.76 & 77.72 & 77.44 & 77.23 & 76.86 \\ \text { LOW } & 75.54 & 74.72 & 74.24 & 74.86 & 76.46 & 76.89 & 77.91 & 77.93 & 77.83 & 77.59 & 77.42 & 77.08\end{array}$

SUMMARY FOR 1995 HIGH 73.94 (Mar. 23, 1995) MEAN $76.25 \quad$ LOW 77.93 (Aug. 1-2, 1995)

Figure 13.-Water level in observation well 31U009, Bullock County. 
313253081433503 , Local number, 32L016.

LOCATION. - Lat $31^{\circ} 32^{\prime} 52^{\prime \prime}$, long 81 $81^{\circ} 33^{\prime} 36^{\prime \prime}$, Hydrologic Unit 03070106.

SITE NAME.-Georgia Geologic Survey, Gardi, test well 2.

INSTRUMENTATION.-Digital recorder.

AQUIFER.-Upper Brunswick.

WELL CHARACTERISTICS. - Drilled observation well, diameter 4 in., depth $340 \mathrm{ft}$, cased to $320 \mathrm{ft}$, screen to $340 \mathrm{ft}$.

DATUM.-Altitude of land-surface datum is $74 \mathrm{ft}$.

REMARKS.-None.

PERIOD OF RECORD. June 1983 to current year. Continuous record since June 1983.

EXTREMES FOR PERIOD OF RECORD. - Highest water level, $49.26 \mathrm{ft}$ below land-surface datum, March 20, 1984;

lowest, $56.93 \mathrm{ft}$ below land-surface datum, January 9, 1991.

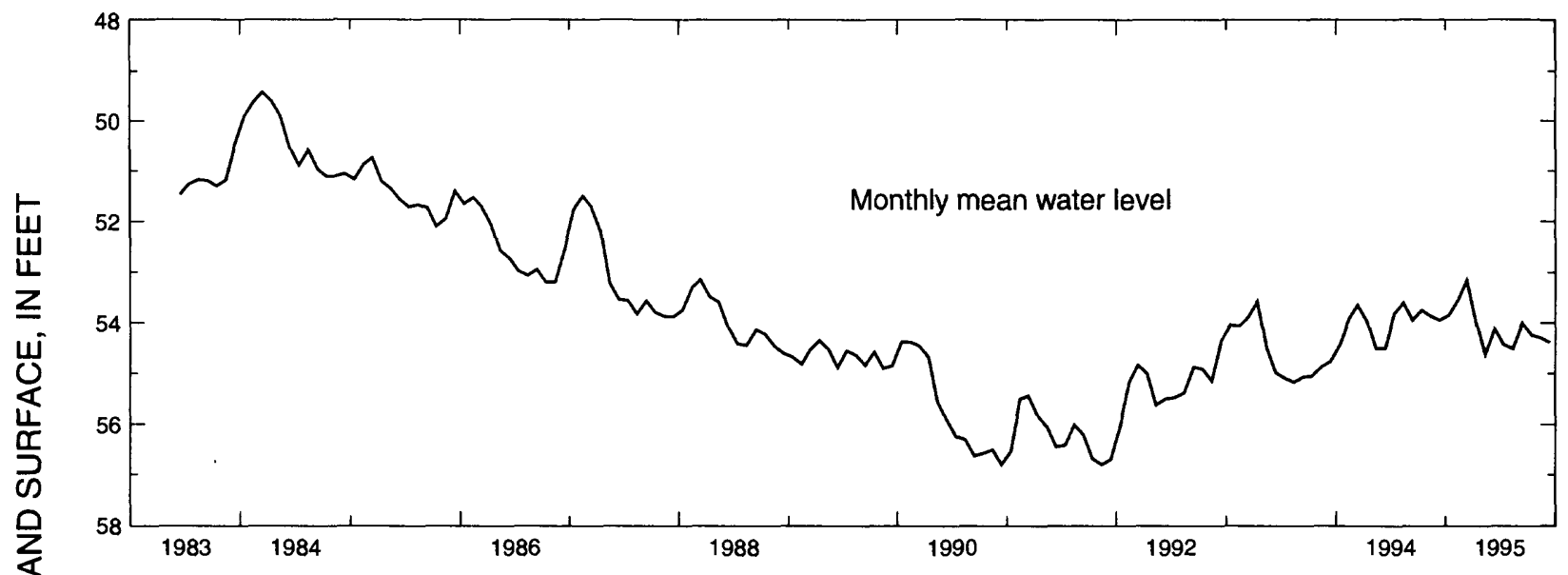

尔

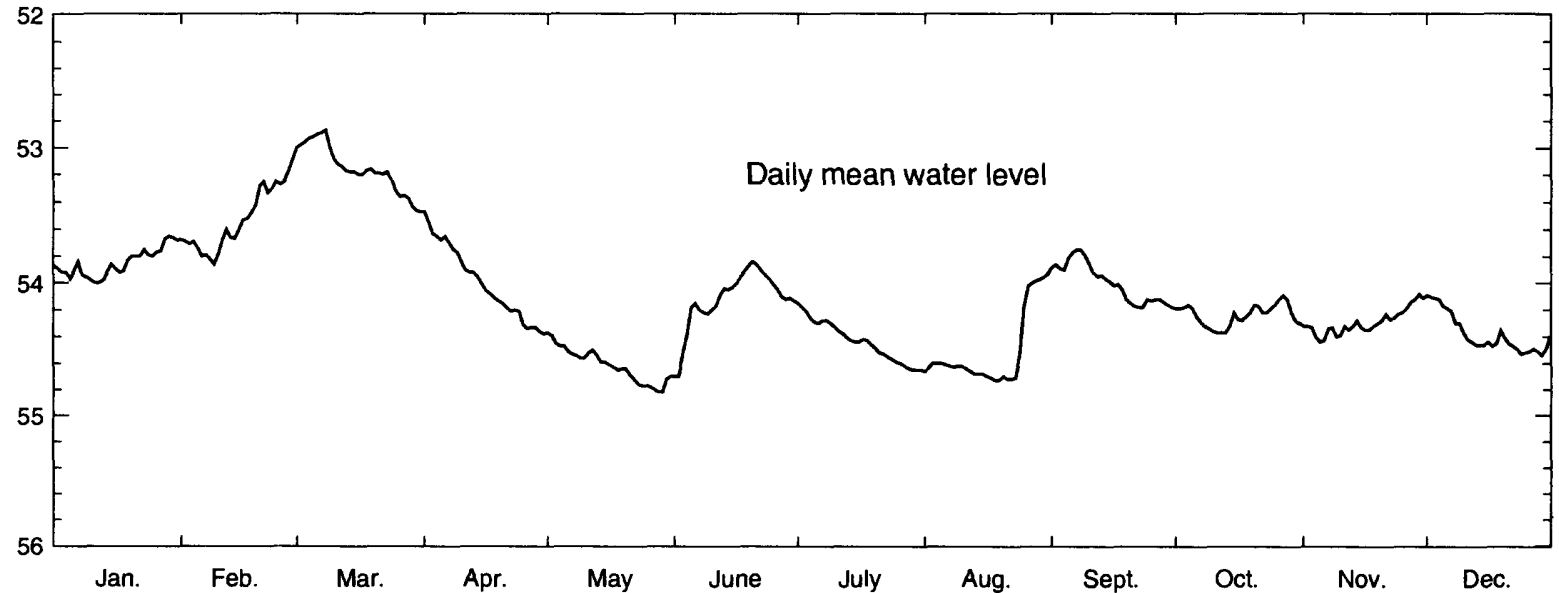

1995

$\begin{array}{lllllllllllll}1995 & \text { JAN } & \text { FEB } & \text { MAR } & \text { APR } & \text { MAY } & \text { JUNE } & \text { JULY } & \text { AUG } & \text { SEPT } & \text { OCT } & \text { NOV } & \text { DEC } \\ \text { HIGH } & 53.65 & 53.09 & 52.87 & 53.47 & 54.37 & 53.84 & 54.15 & 53.93 & 53.75 & 54.09 & 54.08 & 54.09 \\ \text { MEAN } & 53.85 & 53.53 & 53.15 & 53.99 & 54.62 & 54.12 & 54.43 & 54.51 & 54.00 & 54.24 & 54.29 & 54.38 \\ \text { LOW } & 54.00 & 53.86 & 53.47 & 54.38 & 54.82 & 54.70 & 54.65 & 54.73 & 54.18 & 54.37 & 54.44 & 54.54\end{array}$

SUMMARY FOR $1995 \quad$ HIGH 52.87 (Mar. 8, 1995) MEAN $54.10 \quad$ LOW 54.82 (May 28-29, 1995)

Figure 14.-Water level in observation well 32L016, Wayne County. 
310901081284402 Local number, $34 \mathrm{H} 437$.

LOCATION.-Lat $31^{\circ} 09^{\prime} 01^{\prime \prime}$, long $81^{\circ} 28^{\prime} 44^{\prime \prime}$, Hydrologic Unit 03070203.

SITE NAME.-Georgia Geologic Survey, Coffin Park, test well 2.

INSTRUMENTATION.-Electronic data recorder.

AQUIFER.-Upper Brunswick.

WELL CHARACTERISTICS. -Drilled observation well, diameter 4 in., depth $328 \mathrm{ft}$, cased to $315 \mathrm{ft}$, screen to $328 \mathrm{ft}$.

DATUM.-Altitude of land-surface datum is $7 \mathrm{ft}$.

REMARKS. - None.

PERIOD OF RECORD. - November 1983 to current year. Continuous record since November 1983.

EXTREMES FOR PERIOD OF RECORD.-Highest water level, $2.26 \mathrm{ft}$ above land-surface datum, January 7, 1985;

lowest, $7.80 \mathrm{ft}$ below land-surface datum, August 30, 1987.
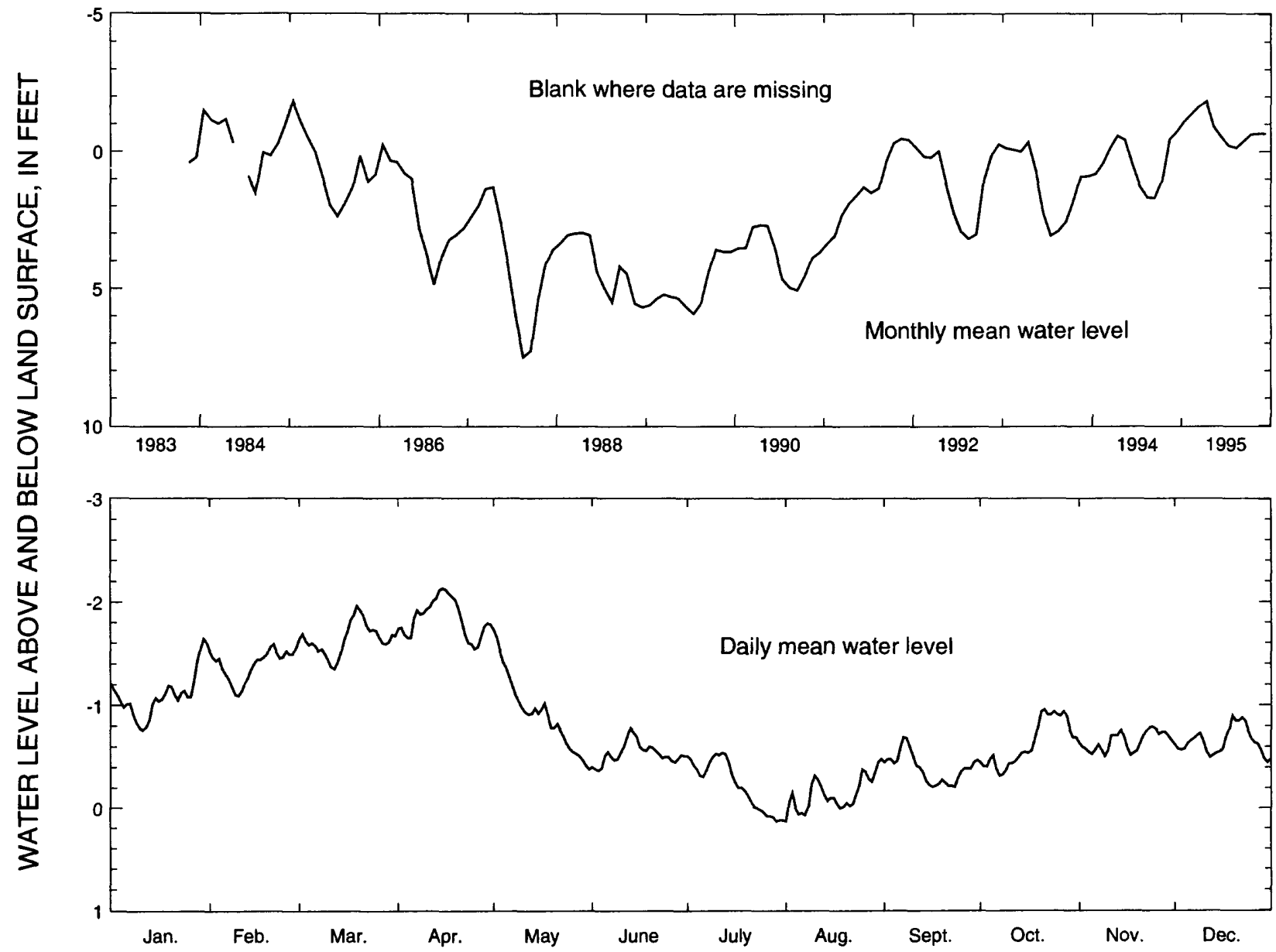

1995

$\begin{array}{lllllllllllll}1995 & \text { JAN } & \text { FEB } & \text { MAR } & \text { APR } & \text { MAY } & \text { JUNE } & \text { JULY } & \text { AUG } & \text { SEPT } & \text { OCT } & \text { NOV } & \text { DEC } \\ \text { HIGH } & -1.64 & -1.59 & -1.96 & -2.13 & -1.73 & -0.78 & -0.54 & -0.48 & -0.69 & -0.96 & -0.79 & -0.90 \\ \text { MEAN } & -1.10 & -1.39 & -1.64 & -1.84 & -0.92 & -0.53 & -0.22 & -0.14 & -0.39 & -0.63 & -0.65 & -0.65 \\ \text { LOW } & -0.76 & -1.09 & -1.35 & -1.54 & -0.38 & -0.37 & 0.13 & 0.13 & -0.21 & -0.32 & -0.51 & -0.45\end{array}$

SUMMARY FOR 1995 HIGH -2.13 (Apr. 15, 1995) MEAN -0.84 LOW 0.13 (July 29,Aug. 1, 1995)

[Negative value indicates water level above land surface]

Figure 15.-Water level in observation well 34H437, Glynn County. 


\section{Floridan Aquifer System}

Water levels in the Floridan aquifer system are monitored in 75 wells; data for 33 of these wells are summarized in this report (figs. 16 and 48). The Floridan aquifer system includes the Upper and Lower Floridan aquifers (table 2). In and near outcrop areas, the Upper Floridan aquifer is semiconfined and water levels in wells tapping the aquifer fluctuate seasonally in response to variations in recharge rate and pumping (Clarke and others, 1990). Near the coast, where the Upper Floridan aquifer is confined, water levels respond primarily to pumping and fluctuations related to recharge are less pronounced (Clarke and others, 1990, p. 31). Most of the water withdrawn from the Floridan aquifer system is from the Upper Floridan aquifer; a few wells in the Savannah area withdraw water from the Lower Floridan aquifer.

\section{Upper Floridan aquifer}

The water level in the Upper Floridan aquifer is monitored in 70 wells and data for 31 of these wells are summarized in this report (fig. 16). For this report, the Upper Floridan aquifer is divided into seven areas: (1) the southwestern area; (2) the south-central area; (3) the east-central area; (4) the Savannah area; (5) the JesupDoctortown area; (6) the Brunswick area; and (7) the St Marys-Okefenokee Swamp area. These areas were divided on the basis of similar hydrologic settings.

\section{Southwestern area}

The water level in the Upper Floridan aquifer in southwestern Georgia was monitored in 24 wells in 1995; data for eight of these wells (fig. 16) are summarized in figures 17-24. In the southwestern area, water levels in wells tapping the Upper Floridan aquifer respond to variations in precipitation, evapotranspiration, pumping, and streamflow (Hayes and others, 1983).

The annual mean water levels in wells 09F520 (fig. 17), 08G001 (fig. 18), 06F001 (fig. 19), and 13L012 (fig. 20) tapping the Upper Floridan aquifer ranged from 2.2 to $7.8 \mathrm{ft}$ lower in 1995 than in 1994 . These four wells are near the Flint River or its tributaries where the aquifer is hydraulically connected to the streams.

In areas away from the Flint River and its tributaries, the Upper Floridan aquifer is confined by thicker overburden, is not well connected to streams, and the water level is not directly influenced by precipitation (Torak and others, 1991). Water-level fluctuations and trends in these areas are indicated by the hydrographs for wells $10 \mathrm{G} 313$ (fig. 21), $13 \mathrm{~L} 003$ (fig. 22), $13 \mathrm{J004}$ (fig. 23), and 15L020 (fig. 24). The annual mean water levels in these wells ranged from 0.3 to $0.8 \mathrm{ft}$ lower in 1995 than in 1994. A record-high daily mean water level was recorded in well $13 \mathrm{J004}$ (fig. 23) that was $0.1 \mathrm{ft}$ higher than the previous record high.

\section{$\underline{\text { South-central area }}$}

The water level in the Upper Floridan aquifer in south-central Georgia was monitored in six wells in 1995 and data from four of these wells (fig. 16) are summarized in figures 25-28. Water levels in wells tapping the aquifer in this area are affected by variations in precipitation, evapotranspiration, and to a lesser degree, pumping (Krause, 1979). In the Valdosta area, water levels also are affected by streamflow (Krause, 1979). The water level generally is highest following the rainy seasons in winter and spring, and lowest in the fall. The annual mean water levels in well $18 \mathrm{~K} 049$ (fig. 25) in Tift County and in well $18 \mathrm{H016}$ (fig. 26) in Cook County were $0.8 \mathrm{ft}$ lower and $0.5 \mathrm{ft}$ higher in 1995 than in 1994, respectively.

The Upper Floridan aquifer receives recharge from the Withlacoochee River north of Valdosta where water from the river flows directly into sinkholes and large solution openings in the aquifer. In this area, increased precipitation and streamflow in winter and early spring result in higher ground-water levels. During most years, decreased precipitation and increased evapotranspiration in the summer results in lower streamflow and, correspondingly, lower ground-water levels. The annual mean water levels in well 19E009 (fig. 27) was $4.5 \mathrm{ft}$ lower in 1995 than in 1994. Continuous water-level monitoring in well 19F039 (fig. 28) was discontinued June 5, 1995. 


\section{East-central area}

The water level in the Upper Floridan aquifer in east-central Georgia was monitored in 18 wells in 1995 and data for three of these wells (fig. 16) are summarized in figures 29-31. Well 21T001 (fig. 29) in Laurens County is located near the recharge area for the Upper Floridan aquifer, and the water level in this well (fig. 29) responds primarily to seasonal fluctuations in precipitation (Krause and Randolph, 1989). The annual mean water level in this well was $0.3 \mathrm{ft}$ lower in 1995 than in 1994 . The 1995 annual mean water levels in well $25 \mathrm{Q} 001$ (fig. 30) in Montgomery County and well 26R001 (fig. 31) in Toombs County were $0.7 \mathrm{ft}$ higher and $0.5 \mathrm{ft}$ lower than in 1994, respectively. A record-low daily mean water level was recorded in well 26R001 (fig. 31) that was $3.2 \mathrm{ft}$ lower than the previous record low.

\section{Savannah area}

The water level in the Upper Floridan aquifer in the Savannah area was monitored in 11 wells in 1995 and data from 7 of these wells (fig. 16) are summarized in figures 32-38. In this area, the water level in the Upper Floridan aquifer mainly is affected by pumping for public supply and industrial uses, and as a result of this pumping, a cone of depression has developed in the potentiometric surface at Savannah (Peck, 1991).

Hydrographs for observation wells near the center of pumping in Savannah and in outlying areas illustrate the effects of pumping on the ground-water levels. The 1995 annual mean water levels in wells in the Savannah area (figs. 32-35) were from $0.3 \mathrm{ft}$ lower to $2.4 \mathrm{ft}$ higher than in 1994. During 1995, the annual mean water levels in wells in the outlying areas (figs. 36-38) were from 0.3 to $1.0 \mathrm{ft}$ higher than in 1994.

\section{Jesup-Doctortown area}

The water level in the Upper Floridan aquifer in the Jesup-Doctortown area was monitored in three wells in 1995 (fig. 16) and data from these wells are summarized in figures 39-41. In this area, water levels in wells tapping the aquifer are affected mainly by industrial pumping at Doctortown, near Jesup. In 1995, partial industrial shutdowns, during which the major ground-water user temporarily ceased pumping, is indicated by sharp water-level rises on all three hydrographs. The 1995 mean water levels in the three wells (figs. 39-41) were from $1.7 \mathrm{ft}$ lower to $0.3 \mathrm{ft}$ higher than in 1994 .

\section{Brunswick area}

The water level in the Upper Floridan aquifer in the Brunswick area was monitored in six wells in 1995 and data from four of these wells (fig. 16) are summarized in this report. In this area, water levels in wells tapping this aquifer primarily are affected by industrial pumping. This pumping has resulted in the development of a cone of depression centered at Brunswick (Peck, 1991). The water-level response to pumping is illustrated in the hydrographs for wells $33 \mathrm{H} 127$ (fig. 42) and 34H403 (fig. 43) tapping the lower water-bearing zone of the Upper Floridan aquifer, and wells $33 \mathrm{H} 133$ (fig. 44) and 34H371 (fig. 45) tapping the upper water-bearing zone of the Upper Floridan aquifer. The annual mean water levels in wells $33 \mathrm{H} 127$ (fig. 42) and 34H403 (fig. 43) were the same and $0.9 \mathrm{ft}$ higher in 1995 than in 1994, respectively, and the annual mean water levels in wells $33 \mathrm{H} 133$ (fig. 44) and 34H371 (fig. 45) were 1.7 and $0.8 \mathrm{ft}$ higher in 1995 than in 1994, respectively.

\section{St Marys-Okefenokee Swamp area}

The water level in the Upper Floridan aquifer in the St Marys-Okefenokee Swamp area (fig. 16) was monitored in two wells and summarized in figures 46-47. Water levels in wells tapping the aquifer in this area are affected by industrial pumping. The 1995 mean water levels in well 33E027 (fig. 46) at Kings Bay and well 27E004 (fig. 47) in western Charlton County were 0.7 and $0.2 \mathrm{ft}$ higher than in 1994, respectively. 


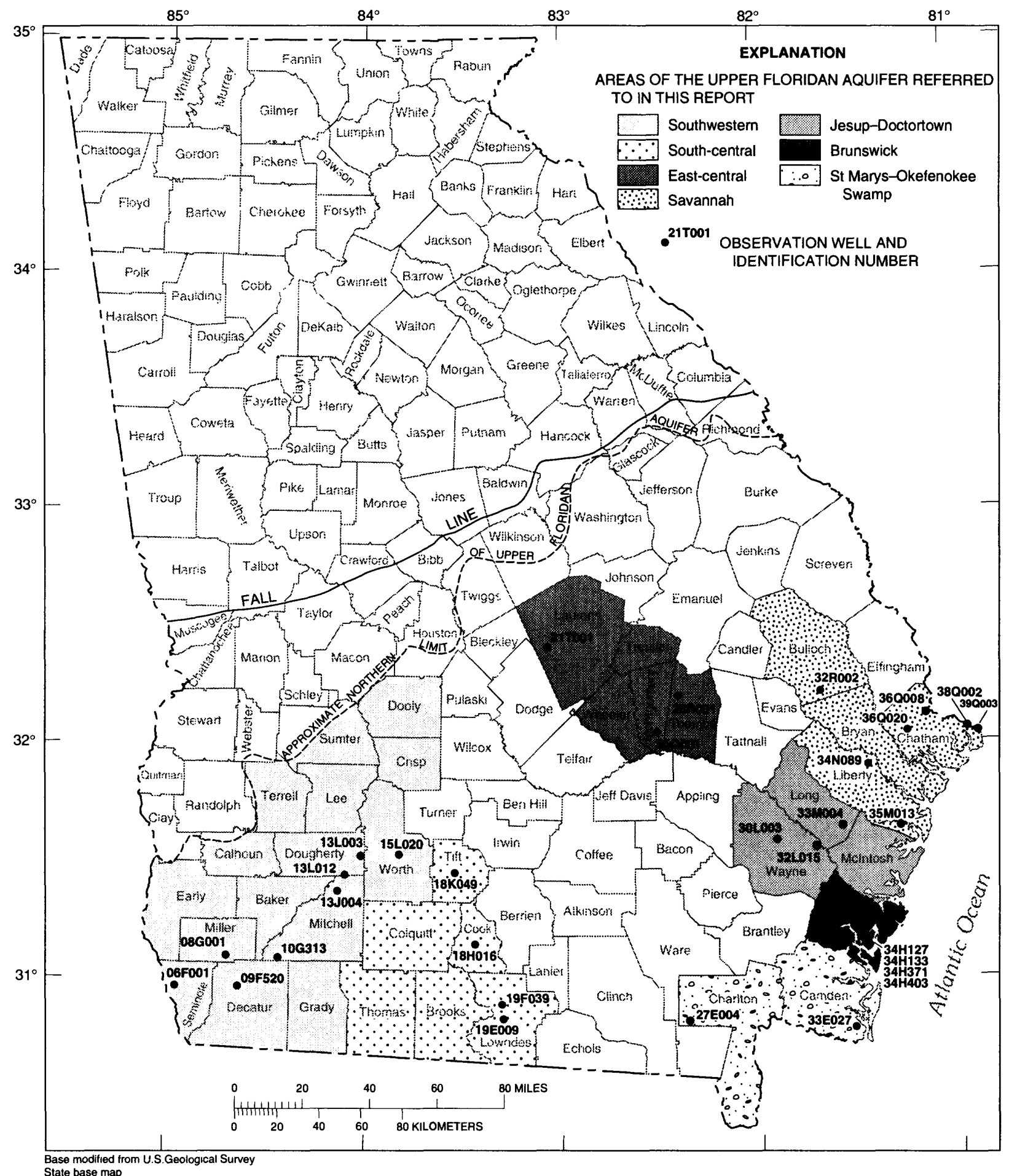

Figure 16.-Subareas and locations of observation wells completed in the Upper Floridan aquifer. 
305736084355801 Local number, 09F520.

LOCATION.-Lat 30 $57^{\prime} 42^{\prime \prime}$, long $84^{\circ} 35^{\prime} 46^{\prime \prime}$, Hydrologic Unit 03130008.

SITE NAME.-Graham Bolton.

INSTRUMENTATION.-Digital recorder.

AQUIFER.-Upper Floridan.

WELL CHARACTERISTICS.-Unused irrigation well, diameter 12 in., depth $251 \mathrm{ft}$, cased to $130 \mathrm{ft}$, open hole.

DATUM.-Altitude of land-surface datum is $128 \mathrm{ft}$.

REMARKS. - This well is about $15 \mathrm{ft}$ from an irrigation well. Water levels for period, July 20-31, are missing.

PERIOD OF RECORD.-May 1969 to current year. Continuous record since May 1969.

EXTREMES FOR PERIOD OF RECORD. - Highest water level, $34.86 \mathrm{ft}$ below land-surface datum, April 15, 1984;

lowest, $54.89 \mathrm{ft}$ below land-surface datum, September 22, 1990.
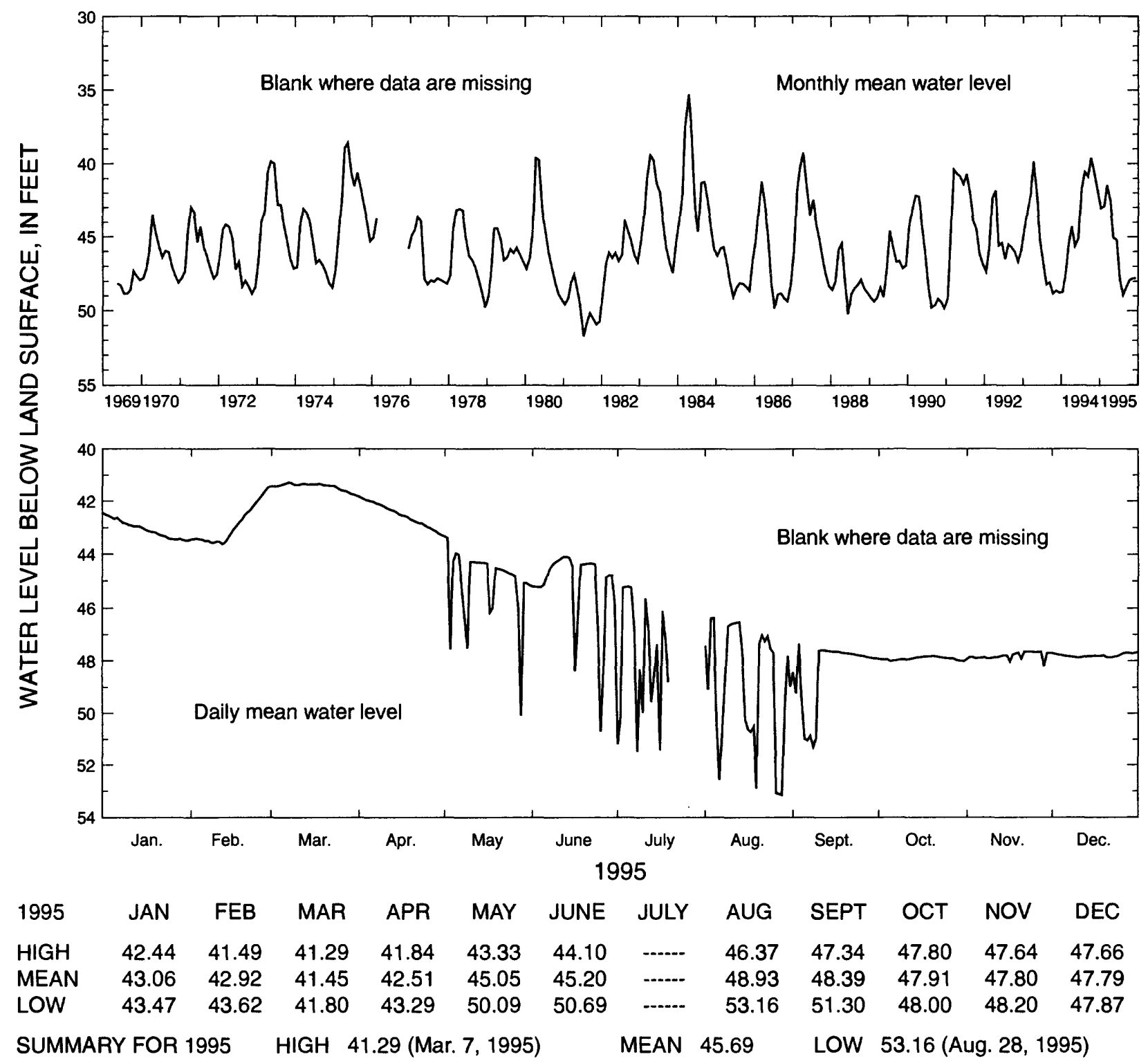

Figure 17.-Water level in observation well 09F520, Decatur County. 
310651084404501 Local number, 08 G001.

LOCATION.-Lat $31^{\circ} 06^{\prime} 51^{\prime \prime}$, long $84^{\circ} 40^{\prime} 45^{\prime \prime}$, Hydrologic Unit 03130010.

SITE NAME.-Viercocken.

INSTRUMENTATION.-Digital recorder.

AQUIFER.-Upper Floridan.

WELL CHARACTERISTICS.-Drilled unused irrigation well, diameter 12 in., depth $255 \mathrm{ft}$, cased to $130 \mathrm{ft}$, open hole.

DATUM.-Altitude of land-surface datum is $150 \mathrm{ft}$.

REMARKS.-None.

PERIOD OF RECORD. - February 1977 to current year. Continuous record since February 1977.

EXTREMES FOR PERIOD OF RECORD. - Highest water level, $11.18 \mathrm{ft}$ below land-surface datum, April 11, 1984;

lowest, $43.88 \mathrm{ft}$ below land-surface datum, July 17, 1981.

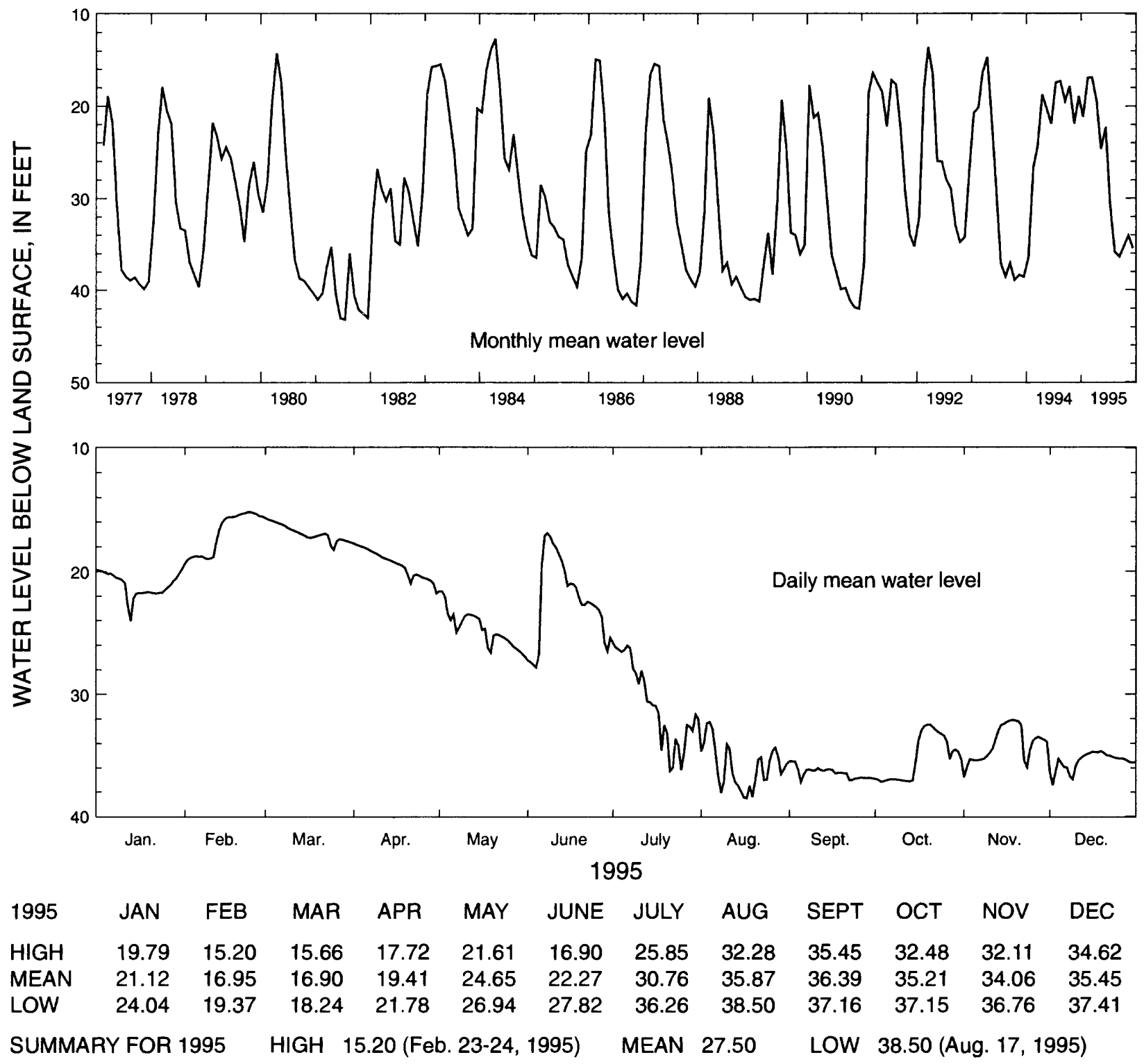

Figure 18.-Water level in observation well 08G001, Miller County. 
305356084534601 Local number, 06 F001.

LOCATION.-Lat $30^{\circ} 54^{\prime} 01^{\prime \prime}$, long $84^{\circ} 53^{\prime} 40^{\prime \prime}$, Hydrologic Unit 03130004.

SITE NAME.-Roddenbery Company Farms, test well 1.

INSTRUMENTATION.-Digital recorder.

AQUIFER.-Upper Floridan.

WELL CHARACTERISTICS. -Drilled observation well, diameter 4 in., depth $150 \mathrm{ft}$, cased to $98.5 \mathrm{ft}$, open hole.

DATUM.-Altitude of land-surface datum is $110 \mathrm{ft}$.

REMARKS.-Water levels for period, January 7-10, are missing.

PERIOD OF RECORD.-March 1979 to July 1982, August 1983 to current year. Continuous record March 1979 to July 1982, and since August 1983.

EXTREMES FOR PERIOD OF RECORD. - Highest water level, $4.13 \mathrm{ft}$ below land-surface datum, March 8, 1984; lowest, $35.65 \mathrm{ft}$ below land-surface datum, October $5,1986$.
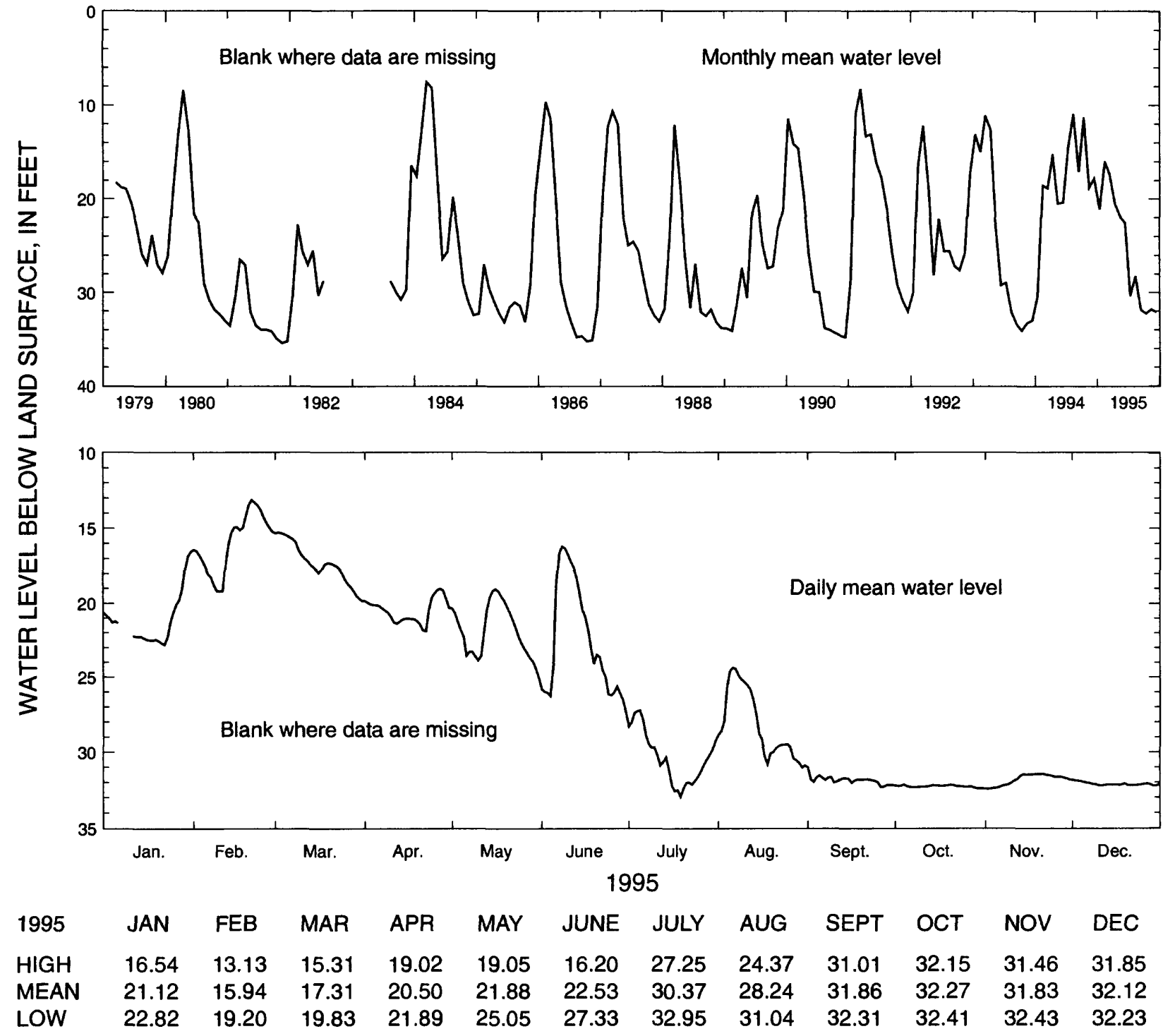

SUMMARY FOR 1995 HIGH 13.13 (Feb. 21, 1995) MEAN $25.61 \quad$ LOW 32.95 (July 19, 1995)

Figure 19.-Water level in observation well 06F001, Seminole County. 
313105084064302 Local number, $13 L 012$.

LOCATION.—Lat $31^{\circ} 31^{\prime} 05^{\prime \prime}$, long $84^{\circ} 06^{\prime} 43^{\prime \prime}$, Hydrologic Unit 03130008.

SITE NAME.-U.S. Geological Survey, test well 3.

INSTRUMENTATION.-Digital recorder.

AQUIFER.-Upper Floridan.

WELL CHARACTERISTICS. -Drilled observation well, diameter $4 \mathrm{in}$., depth $218 \mathrm{ft}$, cased to $54 \mathrm{ft}$, open hole.

DATUM.-Altitude of land-surface datum is $195 \mathrm{ft}$.

REMARKS. - Water levels for period, February 14 to March 5, are missing.

PERIOD OF RECORD.—June 1977 to current year. Continuous record since June 1977.

EXTREMES FOR PERIOD OF RECORD.-Highest water level, $21.92 \mathrm{ft}$ below land-surface datum, March 2, 1979; lowest, $48.18 \mathrm{ft}$ below land-surface datum, July 1, 1981.

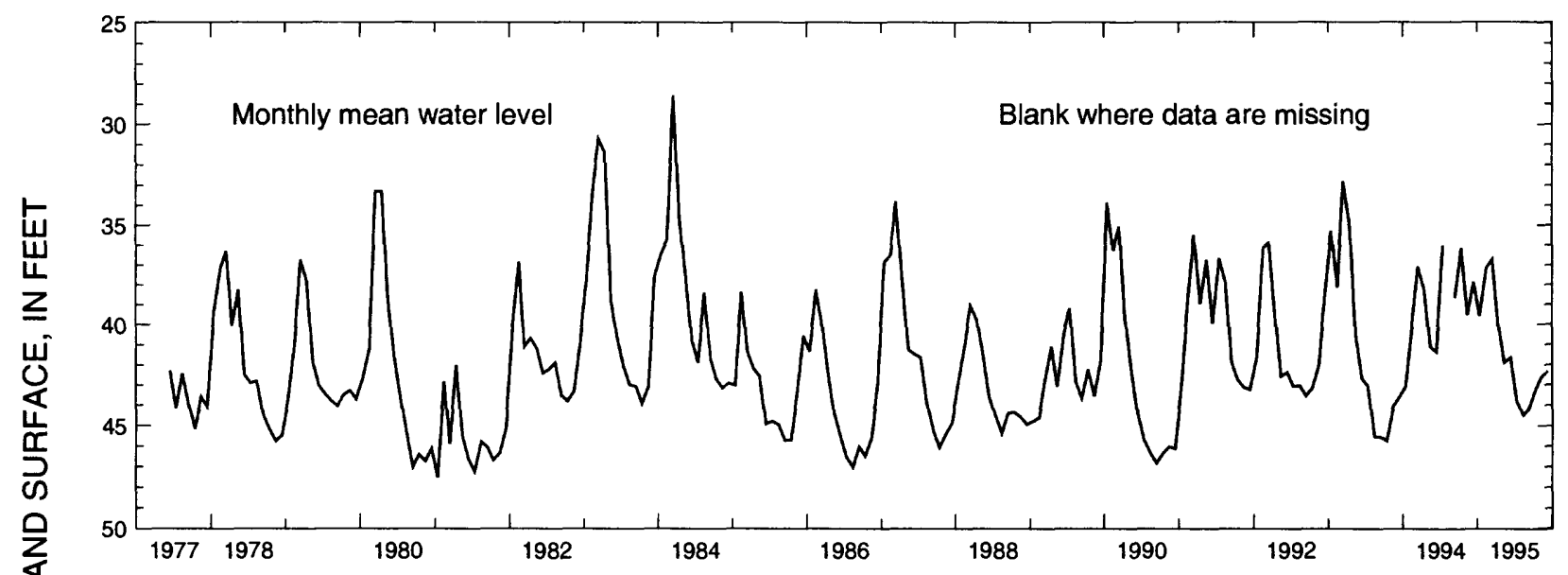

3

\begin{tabular}{|c|c|c|c|c|c|c|c|c|c|c|c|c|}
\hline 1995 & JAN & FEB & MAR & APR & MAY & JUNE & JULY & $A \cup G$ & SEPT & OCT & NOV & DEC \\
\hline GI & 38.87 & .....- & 34.06 & 38.88 & 41.16 & 39.60 & 42.97 & 43.73 & 43.14 & 41.55 & 41.09 & 40.56 \\
\hline$=A N$ & 39.59 & ...... & 36.73 & 40.02 & 41.90 & 41.65 & 43.78 & 44.48 & 44.14 & 43.24 & 42.56 & 42 \\
\hline Low & 40.01 & -...-. & 38.83 & 41.02 & 42.74 & 43.51 & 44.65 & 45.24 & 45.09 & 45.16 & 43.40 & 43.22 \\
\hline $1 M$ & & & $\mathrm{GH}$ & $7 F_{8}$ & 13,1 & & EAN & 1.75 & LOW & 15.2 & 0 & 5) \\
\hline
\end{tabular}

Figure 20.-Water level in observation well 13L012, Dougherty County. 
310507084262201 Local number, 10G313.

LOCATION.-Lat $31^{\circ} 05^{\prime} 07^{\prime \prime}$, long $84^{\circ} 26^{\prime} 22^{\prime \prime}$, Hydrologic Unit 03130008.

SITE NAME.-Harvey Meinders.

INSTRUMENTATION.-Digital recorder.

AQUIFER.-Upper Floridan.

WELL CHARACTERISTICS. - Cable-tool, observation well, diameter 12 in., depth $250 \mathrm{ft}$, cased to $87 \mathrm{ft}$, open hole. DATUM.-Altitude of land-surface datum is $145 \mathrm{ft}$.

REMARKS. - Water levels for period, April 12 to May 1, are missing.

PERIOD OF RECORD.-November 1961 to September 1968, April 1976 to current year. Continuous record November 1961 to September 1968, and since April 1976.

EXTREMES FOR PERIOD OF RECORD. - Highest water level, $32.98 \mathrm{ft}$ below land-surface datum, April 9, 1984; lowest, $60.26 \mathrm{ft}$ below land-surface datum, January 1, 1982.
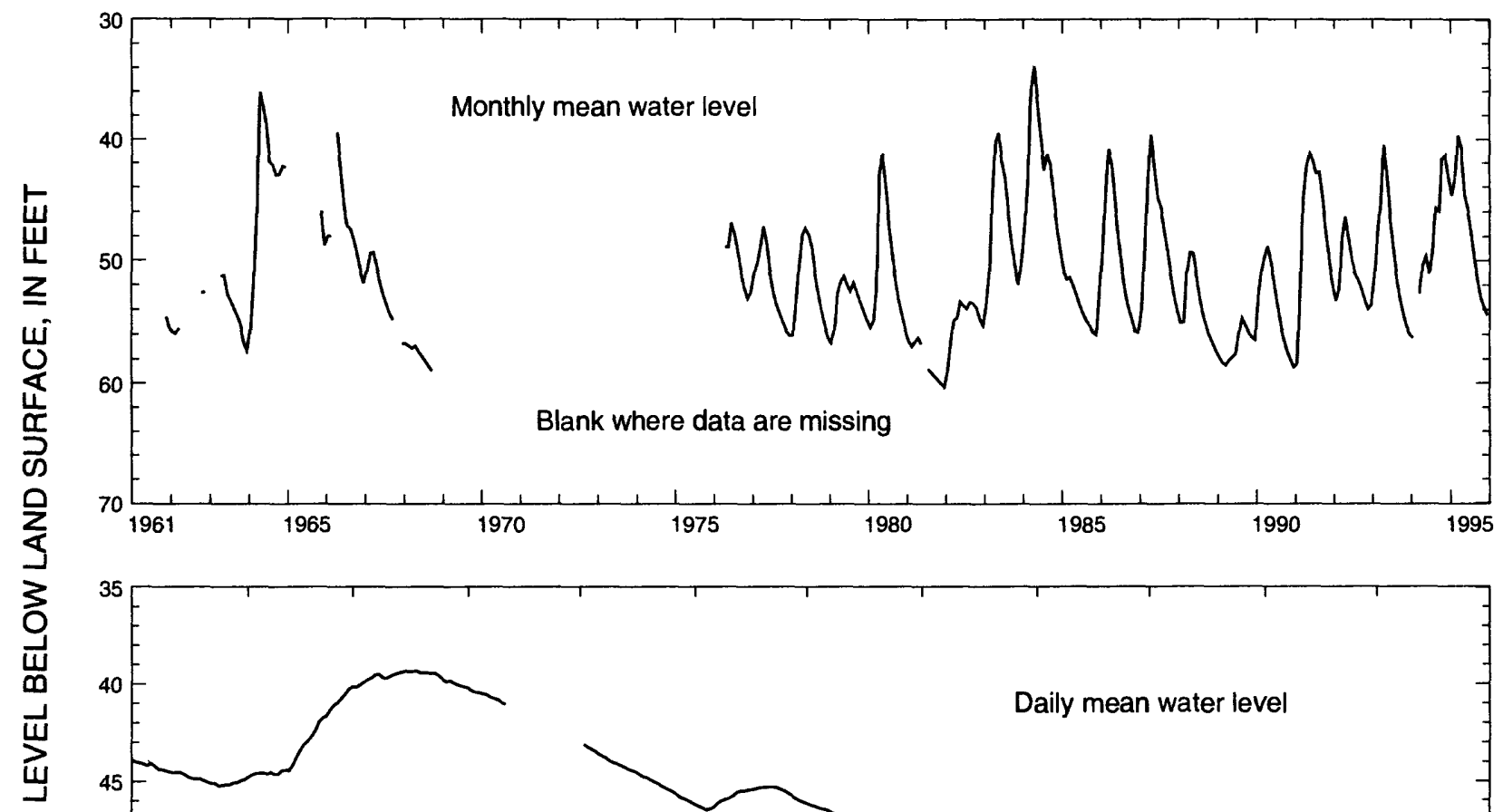

$\begin{array}{lllllllllllll}1995 & \text { JAN } & \text { FEB } & \text { MAR } & \text { APR } & \text { MAY } & \text { JUNE } & \text { JULY } & \text { AUG } & \text { SEPT } & \text { OCT } & \text { NOV } & \text { DEC } \\ \text { HIGH } & 43.89 & 40.28 & 39.34 & \ldots-.- & 43.11 & 45.30 & 46.15 & 48.63 & 50.18 & 52.52 & 53.46 & 54.10 \\ \text { MEAN } & 44.66 & 43.12 & 39.68 & -.-- & 44.62 & 45.77 & 47.48 & 49.83 & 51.47 & 53.01 & 53.82 & 54.47 \\ \text { LOW } & 45.21 & 44.75 & 40.17 & \ldots--.- & 46.10 & 46.49 & 48.58 & 50.88 & 52.47 & 53.43 & 54.09 & 54.73\end{array}$

SUMMARY FOR 1995 HIGH 39.34 (Mar. 15,18, 1995) MEAN 47.79 LOW 54.73 (Dec. 27-28, 1995)

Figure 21.-Water level in observation well 10G313, Mitchell County. 
313748084002901 Local number, 13 L003.

LOCATION.-Lat $31^{\circ} 33^{\prime} 13^{\prime \prime}$, long $84^{\circ} 00^{\prime} 21^{\prime \prime}$, Hydrologic Unit 03130008.

SITE NAME.-City of Albany and Dougherty County.

INSTRUMENTATION.-Digital recorder.

AQUIFER.-Upper Floridan.

WELL CHARACTERISTICS. -Drilled unused supply well, diameter 6 in., depth $259 \mathrm{ft}$, cased to $206 \mathrm{ft}$, open hole.

DATUM.-Altitude of land-surface datum is $225 \mathrm{ft}$.

REMARKS. - None.

PERIOD OF RECORD. - January 1963 to current year. Continuous record since January 1963.

EXTREMES FOR PERIOD OF RECORD.-Highest water level, $17.41 \mathrm{ft}$ below land-surface datum, April 2, 1965;

lowest, $44.89 \mathrm{ft}$ below land-surface datum, December 13, 1981.

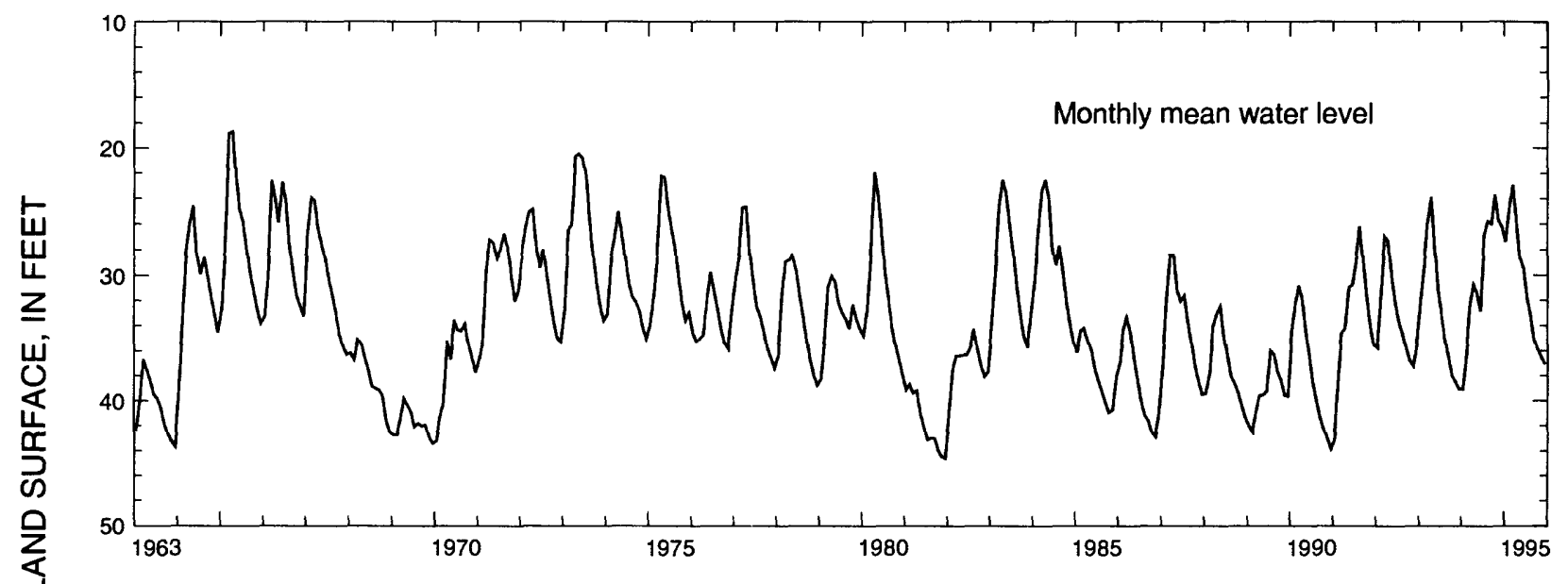

لئ

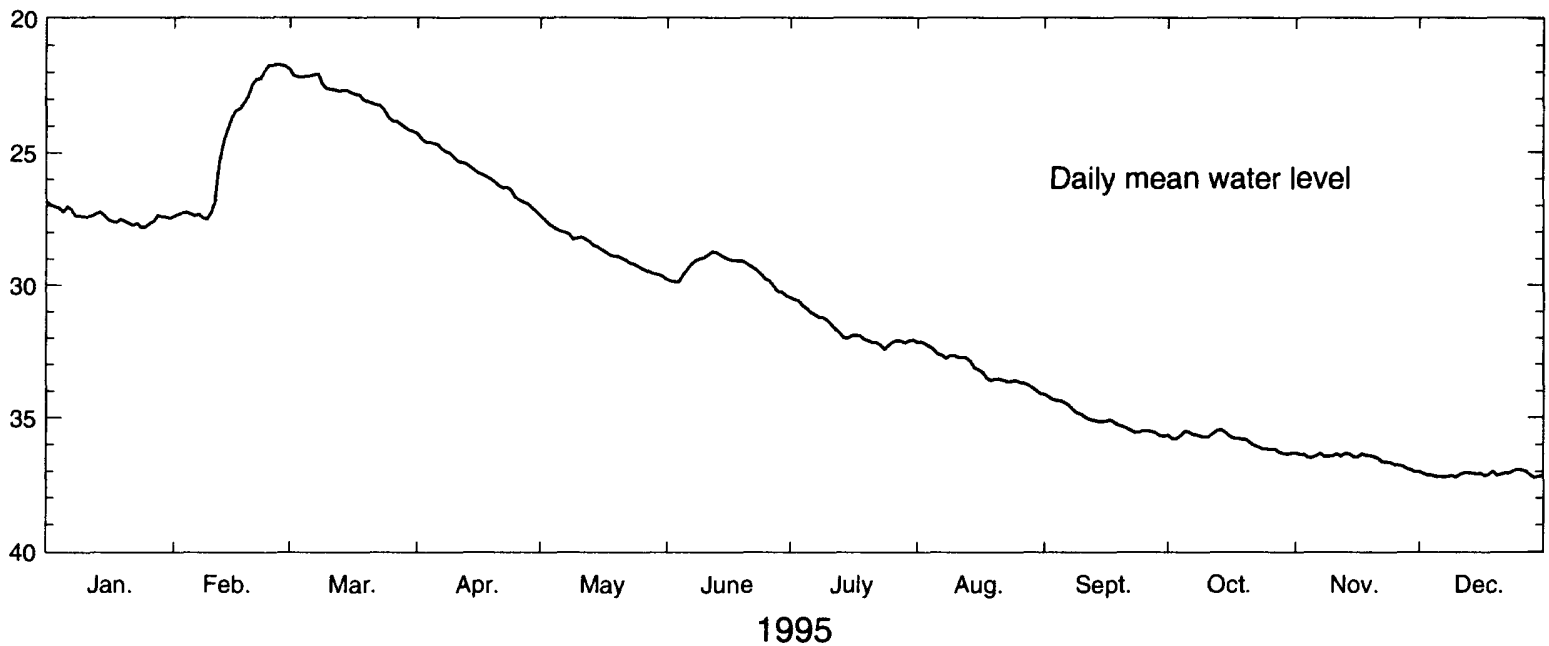

\begin{tabular}{lcccccccccccc}
1995 & JAN & FEB & MAR & APR & MAY & JUNE & JULY & AUG & SEPT & OCT & NOV & DEC \\
HIGH & 26.84 & 21.72 & 21.88 & 24.27 & 27.37 & 28.73 & 30.47 & 32.15 & 34.14 & 35.46 & 36.33 & 36.92 \\
MEAN & 27.40 & 24.59 & 22.91 & 25.69 & 28.62 & 29.40 & 31.68 & 33.15 & 35.06 & 35.86 & 36.53 & 37.10 \\
LOW & 27.81 & 27.50 & 24.20 & 27.20 & 29.67 & 30.40 & 32.43 & 34.12 & 35.70 & 36.37 & 37.02 & 37.22 \\
\multicolumn{3}{l}{ SUMMARY FOR 1995 } & HIGH & 21.72 (Feb. 26, 1995) & MEAN & 30.71 & LOW & 37.22 (Dec. 29, 1995)
\end{tabular}

Figure 22.-Water level in observation well 13L003, Dougherty County. 
312127084065801 Local number, $13 J 004$.

LOCATION.-Lat $31^{\circ} 21^{\prime} 29^{\prime \prime}$, long $84^{\circ} 06^{\prime} 57^{\prime \prime}$, Hydrologic Unit 03130008.

SITE NAME.-Aurora Dairy.

INSTRUMENTATION.-Digital recorder.

AQUIFER.-Upper Floridan.

WELL CHARACTERISTICS.-Drilled observation well, diameter $12 \mathrm{in}$., depth $208 \mathrm{ft}$, cased to $77 \mathrm{ft}$, open hole.

DATUM.-Altitude of land-surface datum is $200 \mathrm{ft}$.

REMARKS.-None.

PERIOD OF RECORD. June 1978 to current year. Continuous record since June 1978.

EXTREMES FOR PERIOD OF RECORD. - Highest water level, $35.68 \mathrm{ft}$ below land-surface datum, March 1,1995;

lowest, $54.05 \mathrm{ft}$ below land-surface datum, December 25, 1990.
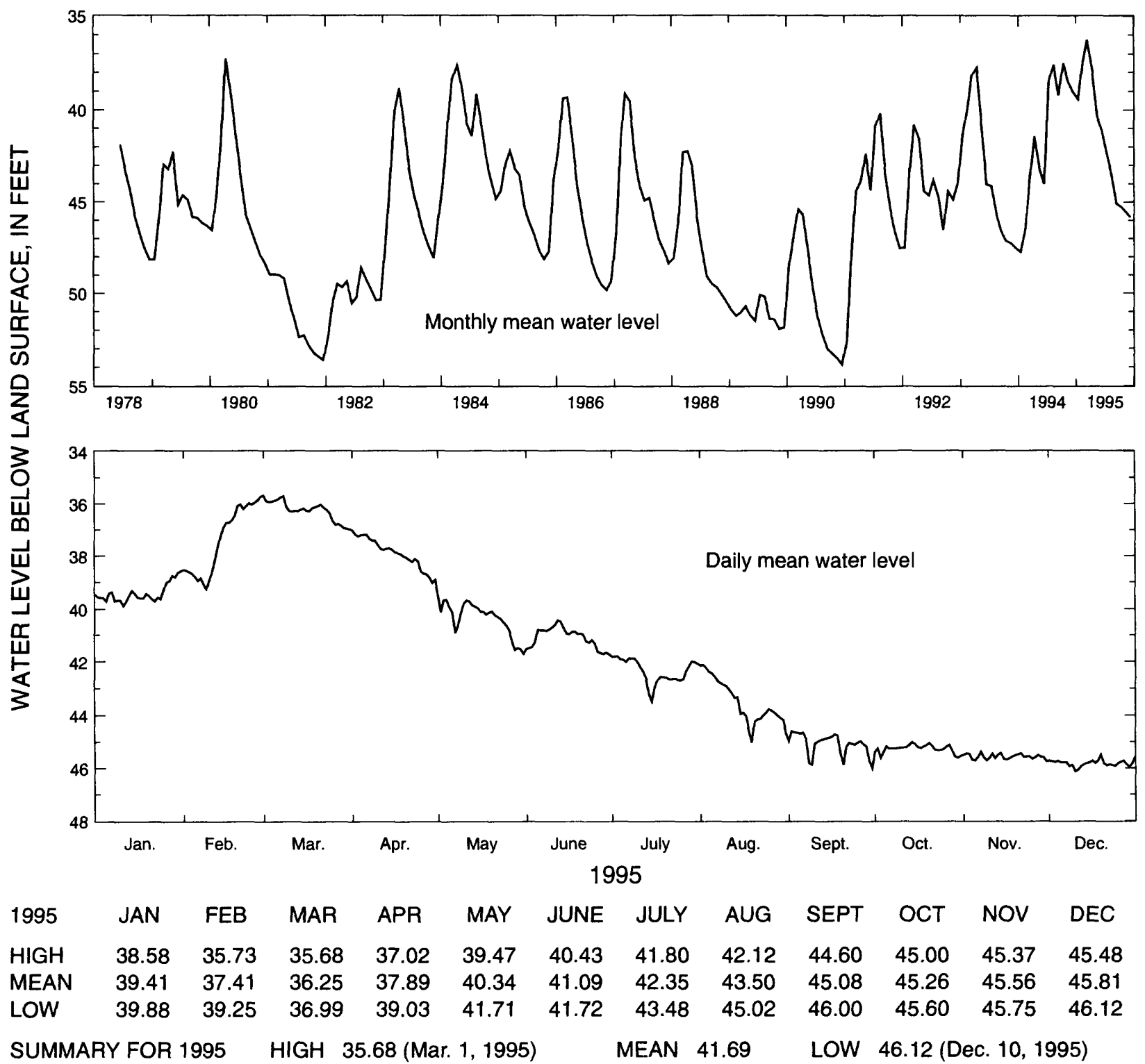

Figure 23.-Water level in observation well 13J004, Mitchell County. 
313146083491601 Local number, 15L020.

LOCATION.-Lat $31^{\circ} 31^{\prime} 46^{\prime \prime}$, long $83^{\circ} 49^{\prime} 16^{\prime \prime}$, Hydrologic Unit 03110204.

SITE NAME.-City of Sylvester.

INSTRUMENTATION.-Digital recorder.

AQUIFER.-Upper Floridan.

WELL CHARACTERISTICS.-Drilled unused municipal well, diameter $18 \mathrm{in}$., depth $450 \mathrm{ft}$, cased to $212 \mathrm{ft}$, open hole.

DATUM.-Altitude of land-surface datum is $420 \mathrm{ft}$.

REMARKS.-None.

PERIOD OF RECORD.-April 1972 to current year. Continuous record since April 1972.

EXTREMES FOR PERIOD OF RECORD.-Highest water level, $191.5 \mathrm{ft}$ below land-surface datum, May 17, 1973;

lowest, $207.07 \mathrm{ft}$ below land-surface datum, August 27, 1993.

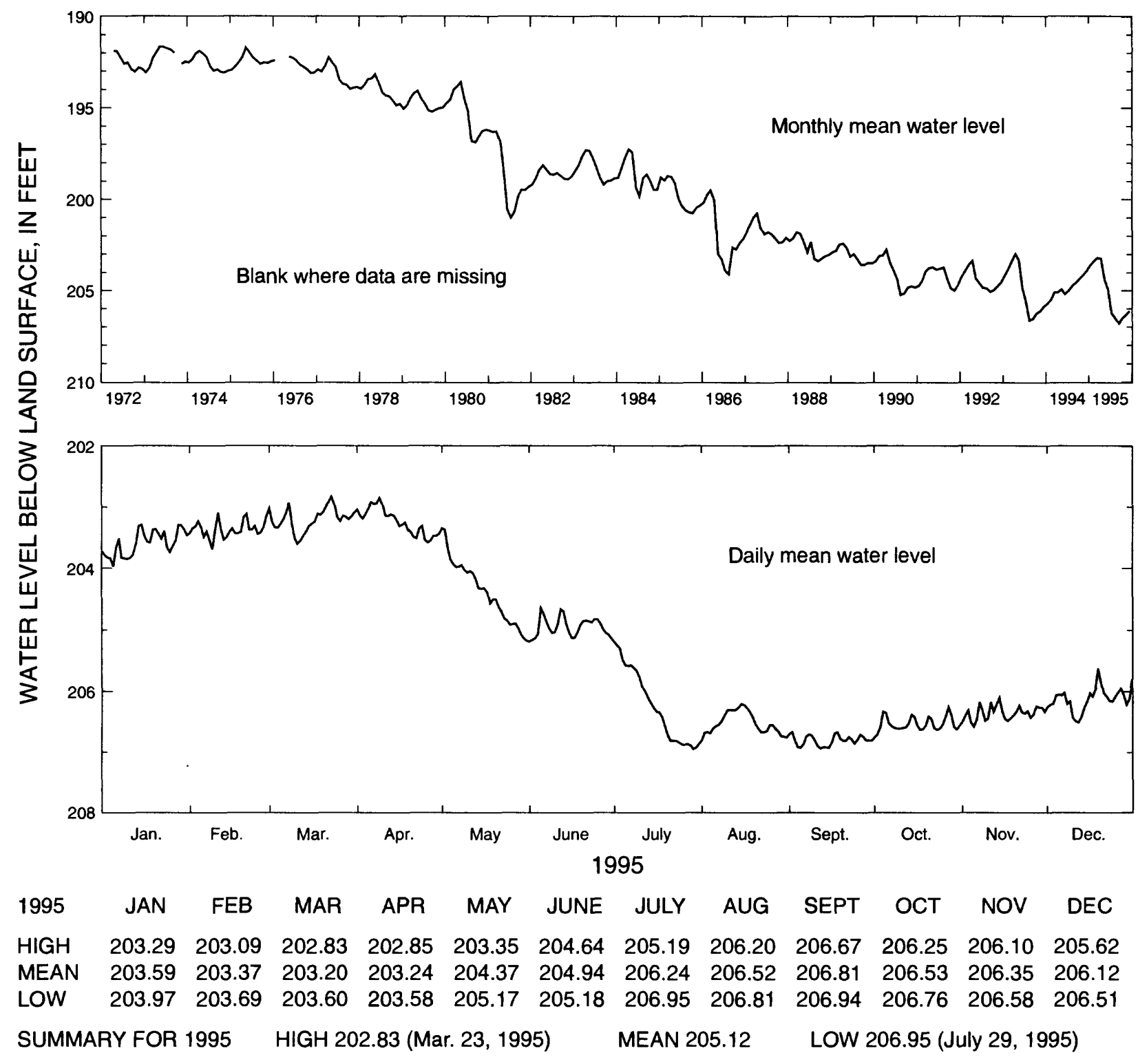

Figure 24.-Water level in observation well 15L020, Worth County. 
312712082593301 Local number, 18 K049.

LOCATION.-Lat $31^{\circ} 27^{\prime} 12^{\prime \prime}$, long $82^{\circ} 59^{\prime} 33^{\prime \prime}$, Hydrologic Unit 03110203.

SITE NAME.-U.S. Geological Survey, test well 1.

INSTRUMENTATION.-Digital recorder.

AQUIFER.-Upper Floridan.

WELL CHARACTERISTICS.-Drilled observation well, diameter 6 in., depth $620 \mathrm{ft}$, cased to $270 \mathrm{ft}$, open hole.

DATUM.-Altitude of land-surface datum is $330 \mathrm{ft}$.

REMARKS.-None.

PERIOD OF RECORD.-March 1978 to current year. Continuous record since March 1978.

EXTREMES FOR PERIOD OF RECORD.-Highest water level, $102.70 \mathrm{ft}$ below land-surface datum, May 14, 1978;

lowest, $126.71 \mathrm{ft}$ below land-surface datum, August 27, 1993.
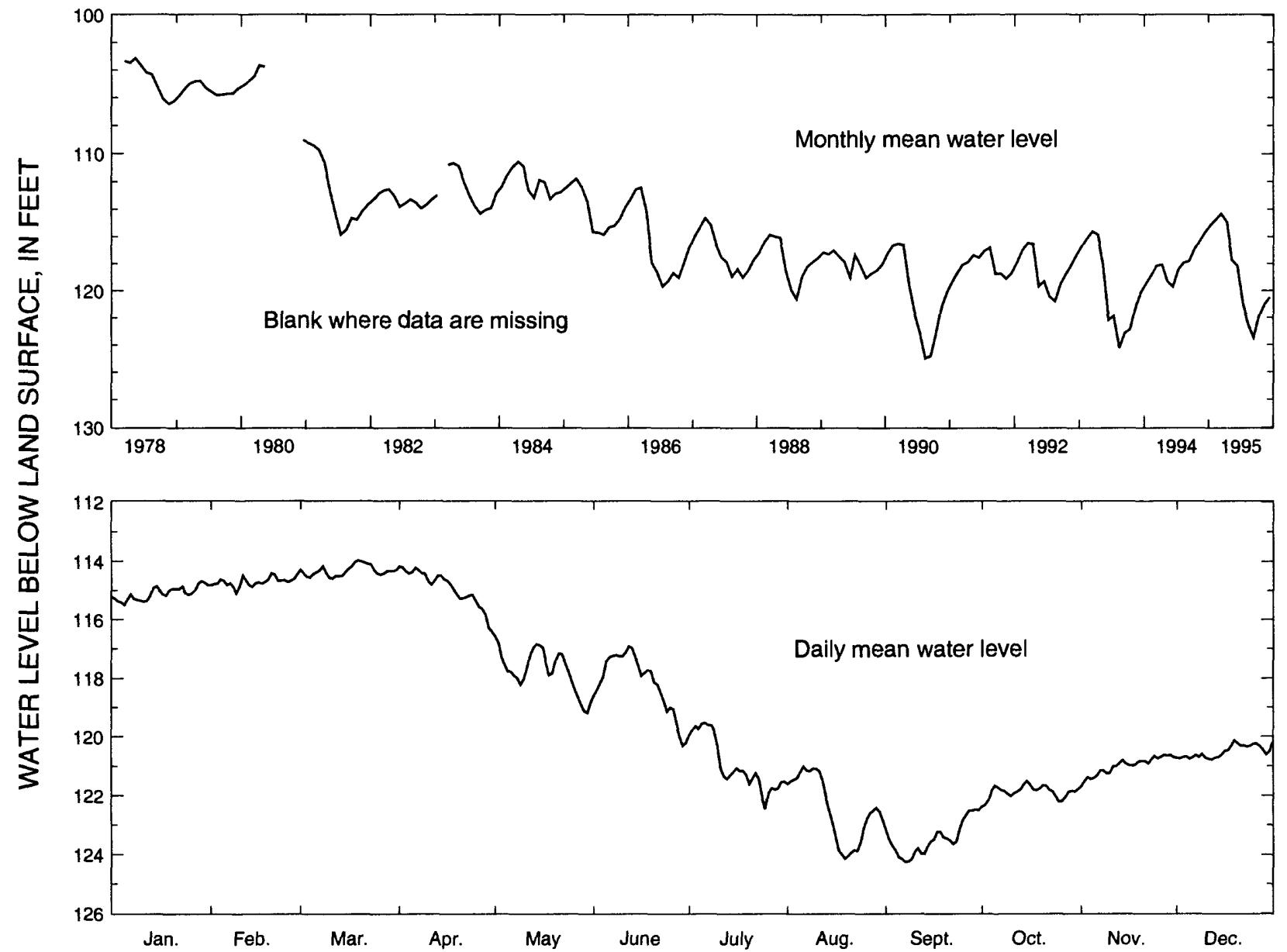

$\begin{array}{lcccccccccccc}1995 & \text { JAN } & \text { FEB } & \text { MAR } & \text { APR } & \text { MAY } & \text { JUNE } & \text { JULY } & \text { AUG } & \text { SEPT } & \text { OCT } & \text { NOV } & \text { DEC } \\ \text { HIGH } & 114.68 & 114.42 & 113.97 & 114.18 & 116.58 & 116.92 & 119.53 & 121.02 & 122.49 & 121.51 & 120.63 & 120.13 \\ \text { MEAN } & 115.10 & 114.70 & 114.32 & 114.91 & 117.73 & 118.16 & 120.95 & 122.47 & 123.48 & 121.88 & 121.01 & 120.52 \\ \text { LOW } & 115.50 & 115.09 & 114.59 & 116.42 & 119.19 & 120.32 & 122.47 & 124.15 & 124.26 & 122.39 & 121.69 & 120.79 \\ \text { SUMMARY FOR 1995 } & \text { HIGH 113.97 (Mar. 19, 1995) } & \text { MEAN 118.79 } & \text { LOW } 124.26 \text { (Sept. 7, 1995) }\end{array}$

Figure 25. -Water level in observation well 18K049, Tift County. 
310813083260301 Local number, $18 \mathrm{H} 016$.

LOCATION.—Lat $31^{\circ} 08^{\prime} 13^{\prime \prime}$, long $83^{\circ} 26^{\prime} 03^{\prime \prime}$, Hydrologic Unit 03110203.

SITE NAME.-U.S. Geological Survey, Adel test well.

INSTRUMENTATION.-Digital recorder.

AQUIFER.-Upper Floridan.

WELL CHARACTERISTICS. -Drilled observation well, diameter 8 in., depth $865 \mathrm{ft}$, cased to $207 \mathrm{ft}$, open hole.

DATUM.-Altitude of land-surface datum is $241 \mathrm{ft}$.

REMARKS.-None.

PERIOD OF RECORD.-December 1964 to current year. Continuous record since June 1965.

EXTREMES FOR PERIOD OF RECORD.- Highest water level, $163.34 \mathrm{ft}$ below land-surface datum, July 5, 1966;

lowest, $177.39 \mathrm{ft}$ below land-surface datum, October 8, 1990.
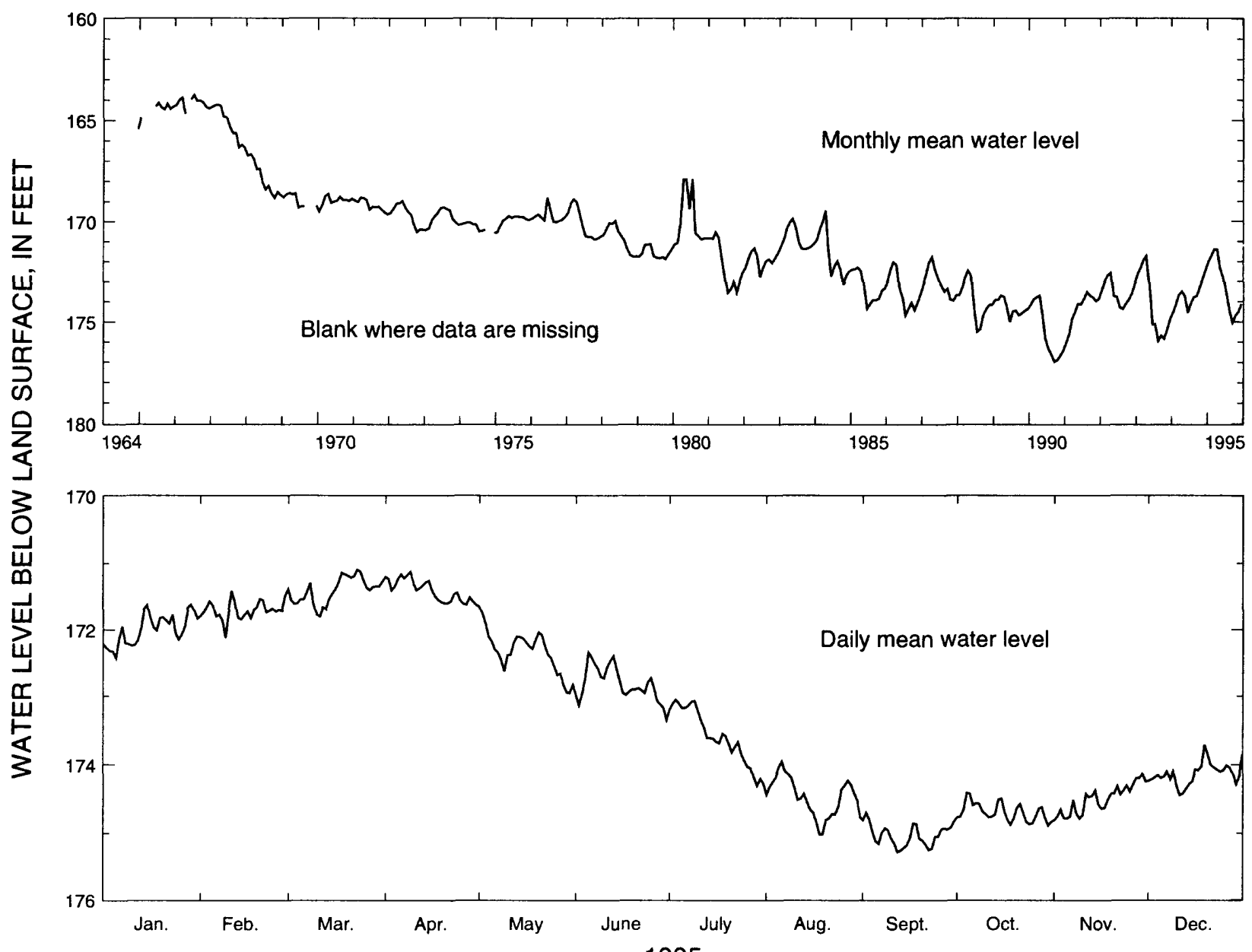

$\begin{array}{lcccccccccccc}1995 & \text { JAN } & \text { FEB } & \text { MAR } & \text { APR } & \text { MAY } & \text { JUNE } & \text { JULY } & \text { AUG } & \text { SEPT } & \text { OCT } & \text { NOV } & \text { DEC } \\ \text { HIGH } & 171.62 & 171.41 & 171.09 & 171.12 & 171.65 & 172.34 & 173.05 & 173.95 & 174.70 & 174.41 & 174.13 & 173.71 \\ \text { MEAN } & 172.00 & 171.71 & 171.40 & 171.41 & 172.33 & 172.81 & 173.59 & 174.47 & 175.03 & 174.70 & 174.50 & 174.13 \\ \text { LOW } & 172.43 & 172.12 & 171.80 & 171.62 & 172.95 & 173.35 & 174.30 & 175.02 & 175.28 & 174.89 & 174.81 & 174.44 \\ \text { SUMMARY FOR 1995 } & \text { HIGH 171.09 (Mar. 23, 1995) } & \text { MEAN 173.18 } & \text { LOW } 175.28 \text { (Sept. 12, 1995) }\end{array}$

Figure 26. -Water level in observation well 18H016, Cook County. 
304949083165301 Local number, 19 E009.

LOCATION.—Lat $30^{\circ} 49^{\prime} 51^{\prime \prime}$, long $83^{\circ} 16^{\prime} 58^{\prime \prime}$, Hydrologic Unit 03110202.

SITE NAME.-City of Valdosta.

INSTRUMENTATION.-Electronic data recorder.

AQUIFER.-Upper Floridan.

WELL CHARACTERISTICS.-Drilled unused municipal supply well, diameter $20 \mathrm{in}$., depth $342 \mathrm{ft}$, cased to $200 \mathrm{ft}$, open hole.

DATUM.-Altitude of land-surface datum is $217 \mathrm{ft}$.

REMARKS.-None.

PERIOD OF RECORD.-February 1957 to current year. Continuous record since February 1957.

EXTREMES FOR PERIOD OF RECORD.-Highest water level, $112.69 \mathrm{ft}$ below land-surface datum, March 9, 1964; lowest, $151.79 \mathrm{ft}$ below land-surface datum, September 19, 1990.

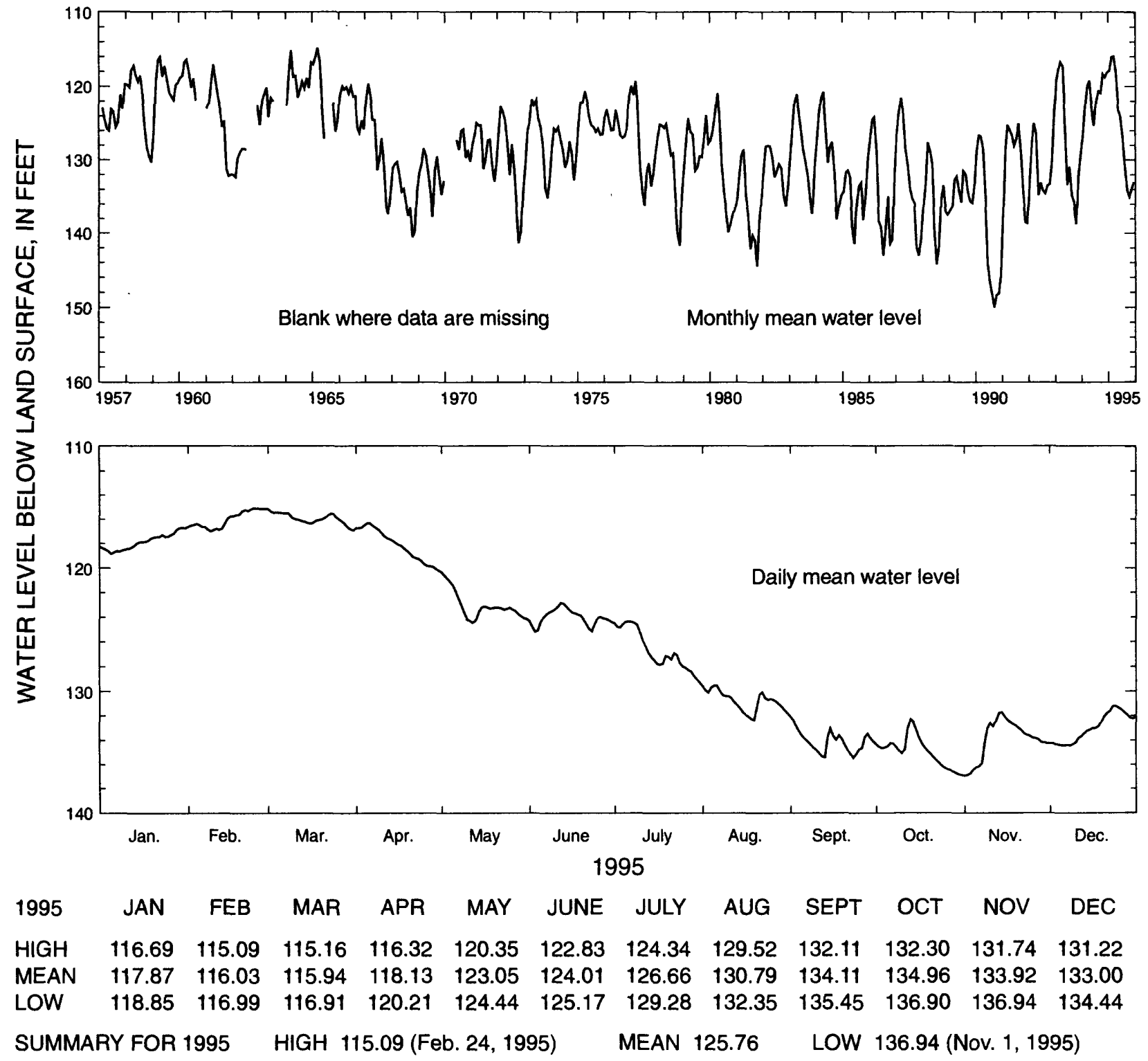

Figure 27.-Water level in observation well 19E009, Lowndes County. 
305241083154401 Local number, 19 F039.

LOCATION.-Lat $30^{\circ} 52^{\prime} 41^{\prime \prime}$, long $83^{\circ} 15^{\prime} 46^{\prime \prime}$, Hydrologic Unit 03110203.

SITE NAME.-City of Valdosta, well 8.

INSTRUMENTATION.-Digital recorder.

AQUIFER.-Upper Floridan.

WELL CHARACTERISTICS.-Drilled unused municipal supply well, diameter $16 \mathrm{in}$., depth $450 \mathrm{ft}$, cased to $350 \mathrm{ft}$, open hole.

DATUM.-Altitude of land-surface datum is $222 \mathrm{ft}$.

REMARKS.-Record collection discontinued June 5, 1995.

PERIOD OF RECORD.-February 1979 to June 5, 1995. Continuous record since February 1979.

EXTREMES FOR PERIOD OF RECORD. - Highest water level, $114.28 \mathrm{ft}$ below land-surface datum, April 9, 1984; lowest, $151.28 \mathrm{ft}$ below land-surface datum, October 9, 1990.
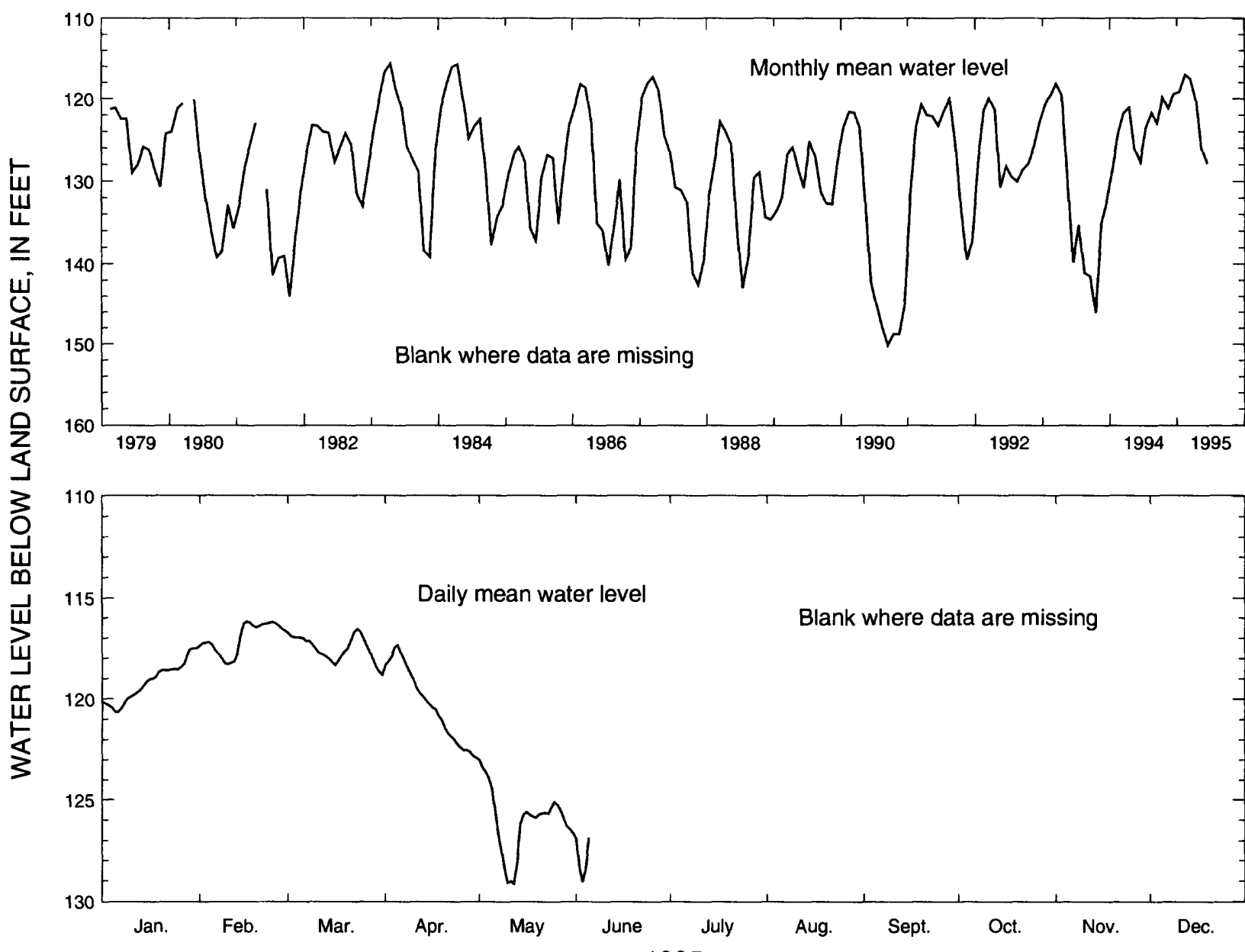

\begin{tabular}{|c|c|c|c|c|c|c|c|c|c|c|c|c|}
\hline 1995 & JAN & FEB & MAR & APR & MAY & JUNE & JULY & $A \cup G$ & SEPT & OCT & NOV & DEC \\
\hline $\mathrm{HIGH}$ & 117.49 & 116.16 & 116.55 & 117.34 & 123.03 & -..--. & --.--- & -..-.. & -..-.- & -..... & -.-... & 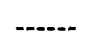 \\
\hline EAN & 119.18 & 117.00 & 117.51 & 120.27 & 126.01 & $\ldots$ & -...-.- & -.---- & -..--. & -..--- & -..--- & $\cdots$ \\
\hline LOW & 120.64 & 118.28 & 118.81 & 122.90 & 129.14 & & $\ldots . .$. & -...- & -...-- & -....- & -..... & $\cdots$ \\
\hline IMN & $\mathrm{FOE}$ & 95 & \multicolumn{4}{|c|}{ HIGH 116.16 (Feb. 16, 1995} & IFA & 30 & \multicolumn{4}{|c|}{ LOW 129.14 (May 12, 1995) } \\
\hline
\end{tabular}

Figure 28.-Water level in observation well 19F039, Lowndes County. 
322652083033001 Local number, 21 T001.

LOCATION. - Lat $32^{\circ} 27^{\prime} 06^{\prime \prime}$, long $83^{\circ} 03^{\prime} 28^{\prime \prime}$, Hydrologic Unit 03070102.

SITE NAME.-Danny Hogan.

INSTRUMENTATION.-Digital recorder.

AQUIFER.-Upper Floridan.

WELL CHARACTERISTICS.-Drilled unused supply well, diameter 4 in., depth $123 \mathrm{ft}$, cased to $89 \mathrm{ft}$, open hole.

DATUM.-Altitude of land-surface datum is $259 \mathrm{ft}$.

REMARKS.-Water levels for period, September 22 to October 3, are missing.

PERIOD OF RECORD.-March 1964 to current year. Continuous record since March 1964.

EXTREMES FOR PERIOD OF RECORD.-Highest water level, $23.62 \mathrm{ft}$ below land-surface datum, January 26, 1987;

lowest, $39.58 \mathrm{ft}$ below land-surface datum, November 12, 1968.
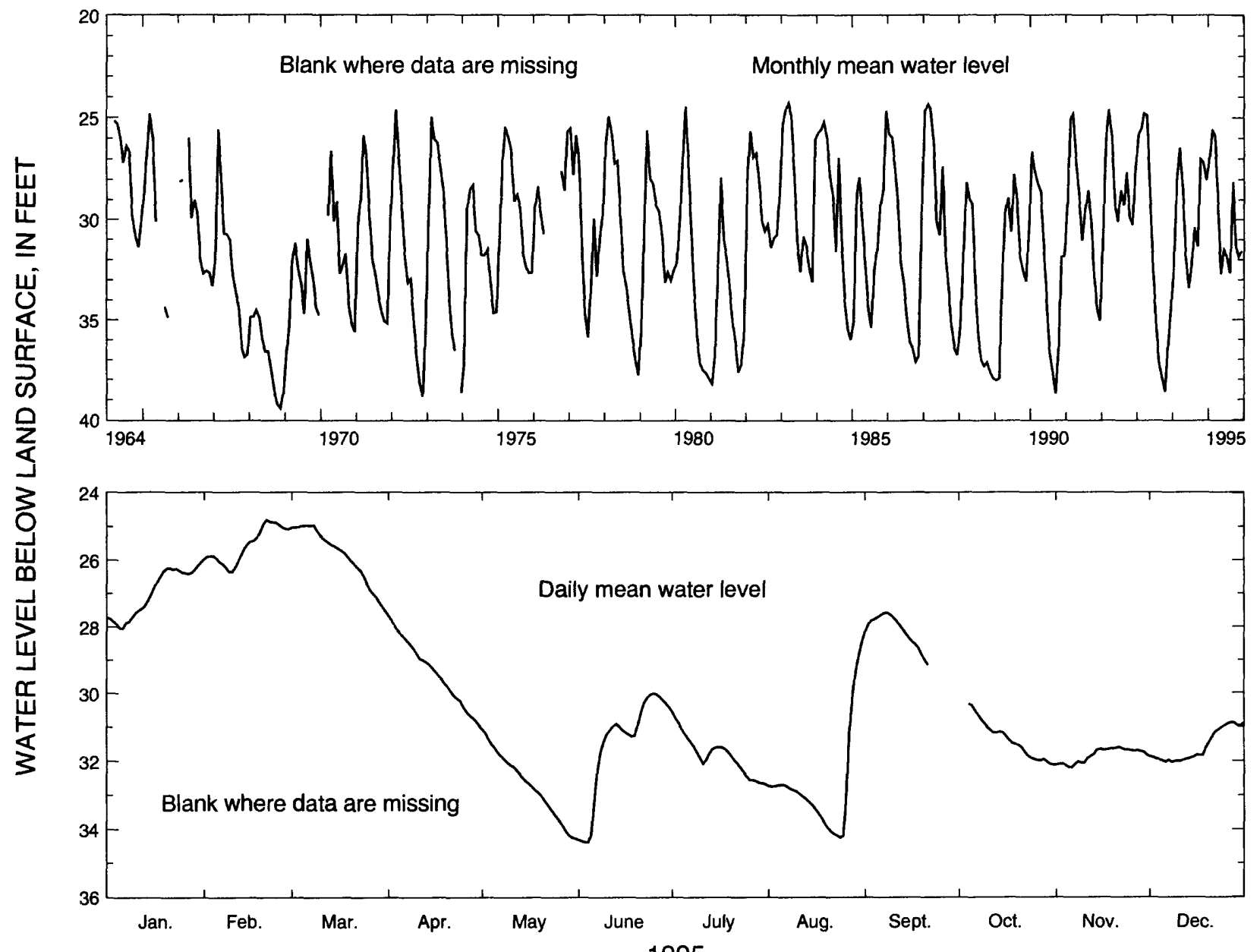

$\begin{array}{lcccccccccccc}1995 & \text { JAN } & \text { FEB } & \text { MAR } & \text { APR } & \text { MAY } & \text { JUNE } & \text { JULY } & \text { AUG } & \text { SEPT } & \text { OCT } & \text { NOV } & \text { DEC } \\ \text { HIGH } & 26.06 & 24.80 & 24.96 & 27.67 & 31.07 & 30.01 & 30.57 & 28.45 & \ldots-. . & 30.33 & 31.60 & 30.88 \\ \text { MEAN } & 26.99 & 25.56 & 25.87 & 29.35 & 32.71 & 31.49 & 31.83 & 32.67 & \ldots-. . & 31.38 & 31.84 & 31.58 \\ \text { LOW } & 28.05 & 26.35 & 27.54 & 30.96 & 34.28 & 34.39 & 32.68 & 34.24 & \ldots-. . & 32.11 & 32.19 & 32.04 \\ \text { SUMMARY FOR 1995 } & \text { HIGH } & 24.80 \text { (Feb. 21, 1995) } & \text { MEAN } & 30.02 & \text { LOW } & 34.39 \text { (June 4, 1995) }\end{array}$

Figure 29.-Water level in observation well 21T001, Laurens County. 
320226082301101 Local number, $25 \mathrm{Q} 001$.

LOCATION.-Lat $32^{\circ} 02^{\prime} 25^{\prime \prime}$, long 82 $30^{\prime} 05^{\prime \prime}$, Hydrologic Unit 03070106.

SITE NAME.-Montgomery County Board of Education.

INSTRUMENTATION.-Digital recorder.

AQUIFER. - Upper Floridan.

WELL CHARACTERISTICS.-Drilled unused supply well, diameter 6 in., depth $536 \mathrm{ft}$, cased to $421 \mathrm{ft}$, open hole.

DATUM.-Altitude of land-surface datum is $190 \mathrm{ft}$.

REMARKS.-None.

PERIOD OF RECORD. -June 1966 to current year. Continuous record since June 1966.

EXTREMES FOR PERIOD OF RECORD. - Highest water level, $64.13 \mathrm{ft}$ below land-surface datum, June 10, 1966; lowest, $82.94 \mathrm{ft}$ below land-surface datum, October 7, 1990.

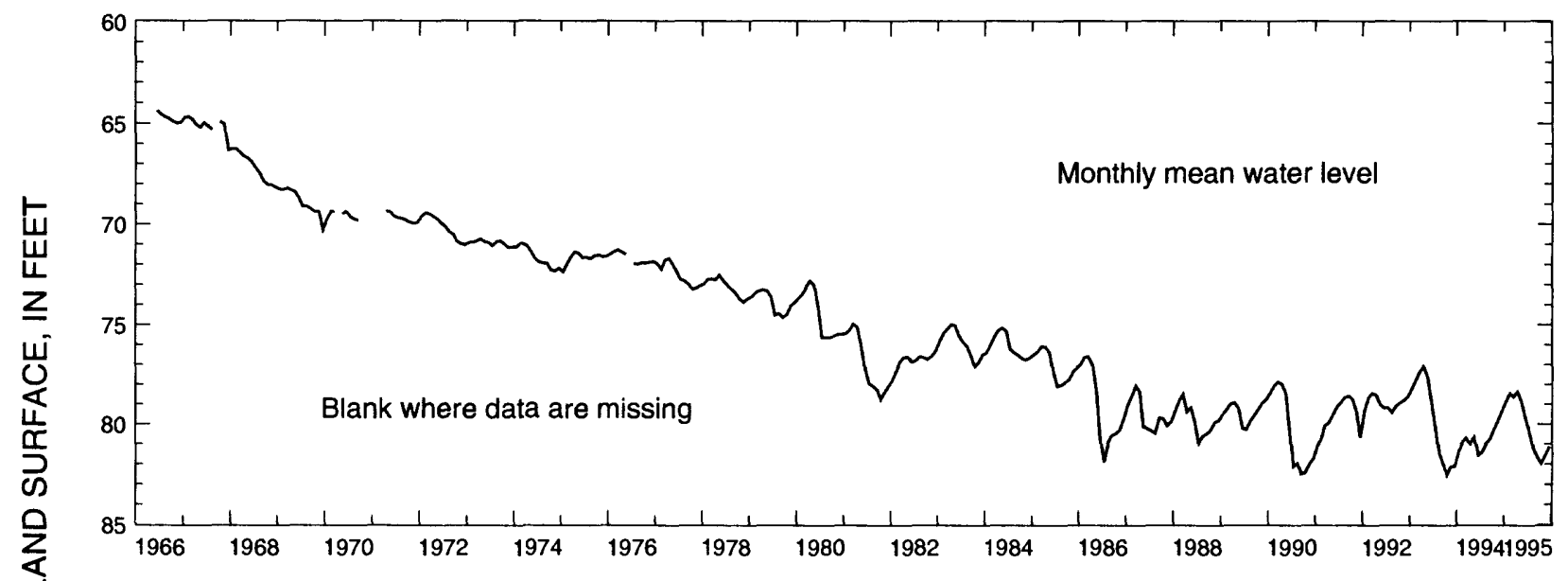

$\begin{array}{lllllllllllll}1995 & \text { JAN } & \text { FEB } & \text { MAR } & \text { APR } & \text { MAY } & \text { JUNE } & \text { JULY } & \text { AUG }^{*} & \text { SEPT } & \text { OCT } & \text { NOV } & \text { DEC } \\ \text { HIGH } & 78.54 & 78.20 & 77.97 & 78.22 & 78.28 & 79.44 & 79.75 & 80.90 & 81.41 & 81.54 & 81.23 & 80.87 \\ \text { MEAN } & 78.86 & 78.45 & 78.62 & 78.37 & 78.88 & 79.66 & 80.33 & 81.24 & 81.66 & 81.97 & 81.56 & 81.13 \\ \text { LOW } & 79.19 & 78.70 & 79.02 & 78.61 & 79.98 & 80.08 & 80.96 & 81.67 & 81.87 & 82.29 & 82.01 & 81.30\end{array}$

SUMMARY FOR 1995 HIGH 77.97 (Mar. 8, 1995) MEAN $80.07 \quad$ LOW 82.29 (Oct. 23, 1995)

Figure 30.-Water level in observation well 25Q001, Montgomery County. 
321302082243601 Local number, $26 \mathrm{R} 001$.

LOCATION. - Lat $32^{\circ} 13^{\prime} 02^{\prime \prime}$, long 82 $24^{\prime} 36^{\prime \prime}$, Hydrologic Unit 03070107.

SITE NAME.-City of Vidalia, well 2.

INSTRUMENTATION.-Digital recorder.

AQUIFER.-Upper Floridan.

WELL CHARACTERISTICS. - Drilled municipal supply well, diameter 12 in., depth 1,000 ft, cased to $720 \mathrm{ft}$, open hole. DATUM.-Altitude of land-surface datum is $285 \mathrm{ft}$.

REMARKS.-Water levels for periods, May 8-16, June 18 to July 5, and August 20 to September 19, are missing. PERIOD OF RECORD.-April 1974 to current. Continuous record since April 1974.

EXTREMES FOR PERIOD OF RECORD.-Highest water level, $151.64 \mathrm{ft}$ below land-surface datum, April 15, 1974; lowest, $175.12 \mathrm{ft}$ below land-surface datum, August 16, 1995.

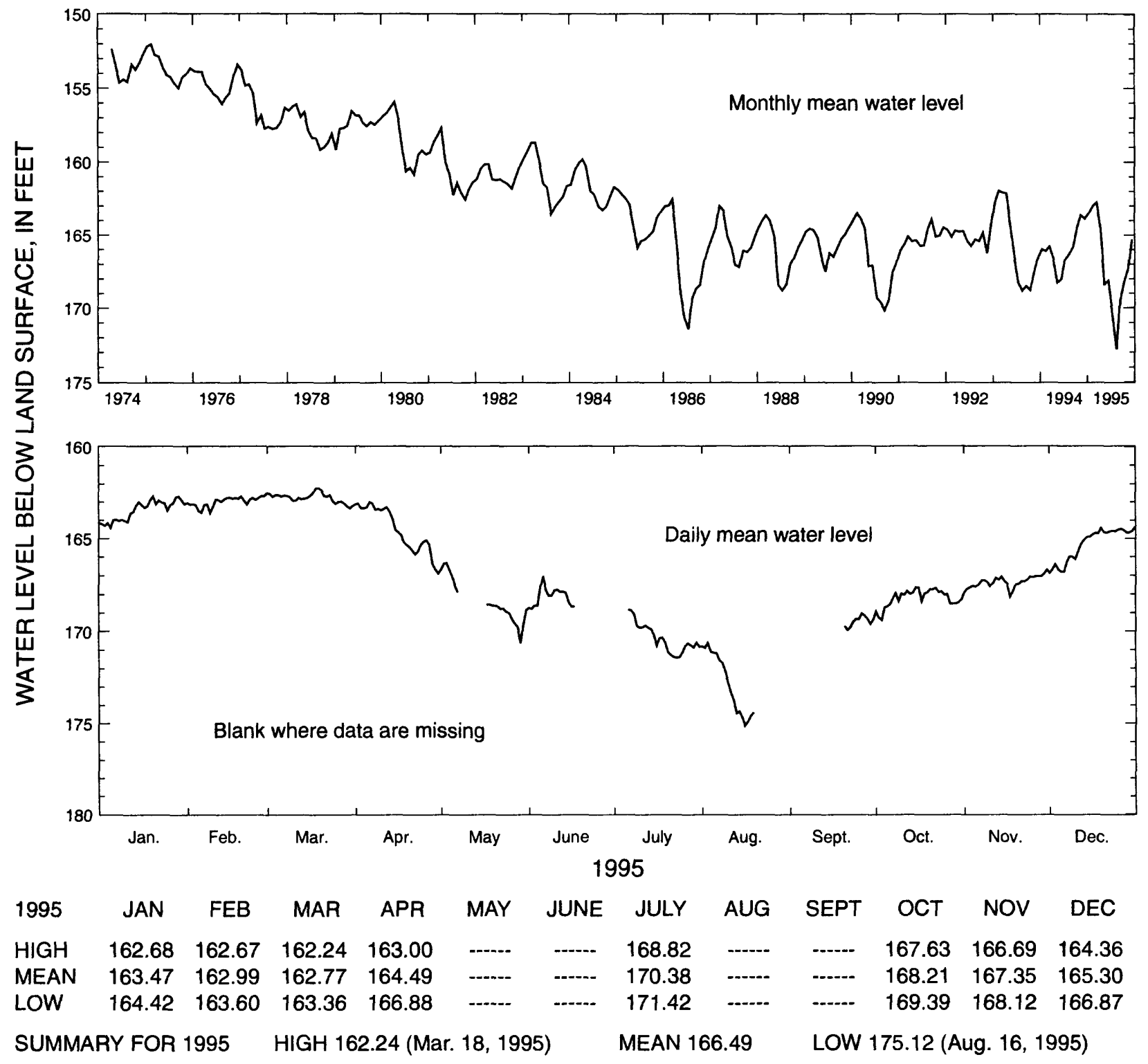

Figure 31.-Water level in observation well 26R001, Toombs County. 
320530081085001 Local number, 36Q008.

LOCATION. - Lat $32^{\circ} 05^{\prime} 30^{\prime \prime}$, long $81^{\circ} 08^{\prime} 50^{\prime \prime}$, Hydrologic Unit 03060204.

SITE NAME.-Layne-Atlantic Co.

INSTRUMENTATION.-Digital recorder.

AQUIFER.-Upper Floridan.

WELL CHARACTERISTICS. -Drilled unused supply well, diameter $4 \mathrm{in}$., depth $406 \mathrm{ft}$, cased to $250 \mathrm{ft}$, open hole.

DATUM.-Altitude of land-surface datum is $9.91 \mathrm{ft}$.

REMARKS.-None.

PERIOD OF RECORD.-February 1954 to current year. Continuous record since February 1954.

EXTREMES FOR PERIOD OF RECORD. - Highest water level, $49.17 \mathrm{ft}$ below land-surface datum, July 11, 1954; lowest, $124.40 \mathrm{ft}$ below land-surface datum, August 30, 1980.

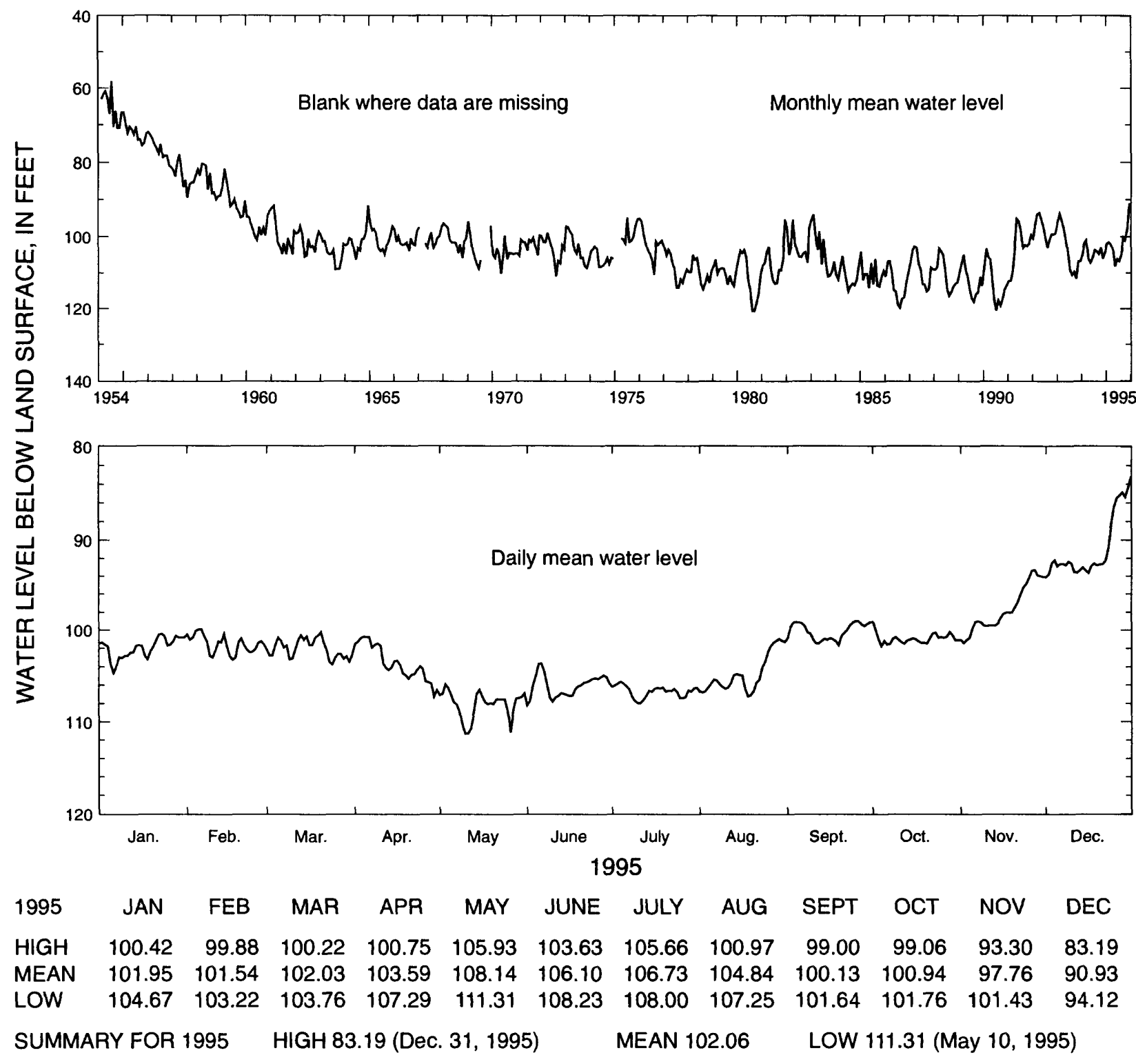

Figure 32.-Water level in observation well $36 \mathrm{Q} 008$, Chatham County. 
320021081124801 Local number, 36Q020.

LOCATION.-Lat $32^{\circ} 00^{\prime} 18^{\prime \prime}$, long $81^{\circ} 12^{\prime} 48^{\prime \prime}$, Hydrologic Unit 03060204.

SITE NAME.-H.J. Morrison.

INSTRUMENTATION.-Digital recorder.

AQUIFER.-Upper Floridan.

WELL CHARACTERISTICS.-Drilled unused supply well, diameter $3 \mathrm{in}$., depth $365 \mathrm{ft}$, cased to $330 \mathrm{ft}$, open hole.

DATUM.-Altitude of land-surface datum is $13 \mathrm{ft}$.

REMARKS. - Water levels for periods, January 1-5 and August 31 to October 24, are missing.

PERIOD OF RECORD.-March 1958 to current year. Continuous record since August 1958.

EXTREMES FOR PERIOD OF RECORD. - Highest water level, $17.66 \mathrm{ft}$ below land-surface datum, June 28, 1958;

lowest, recorded, $58.56 \mathrm{ft}$ below land-surface datum, July 12, 1990, but may have been lower during period of missing record, July 13-22, 1990.
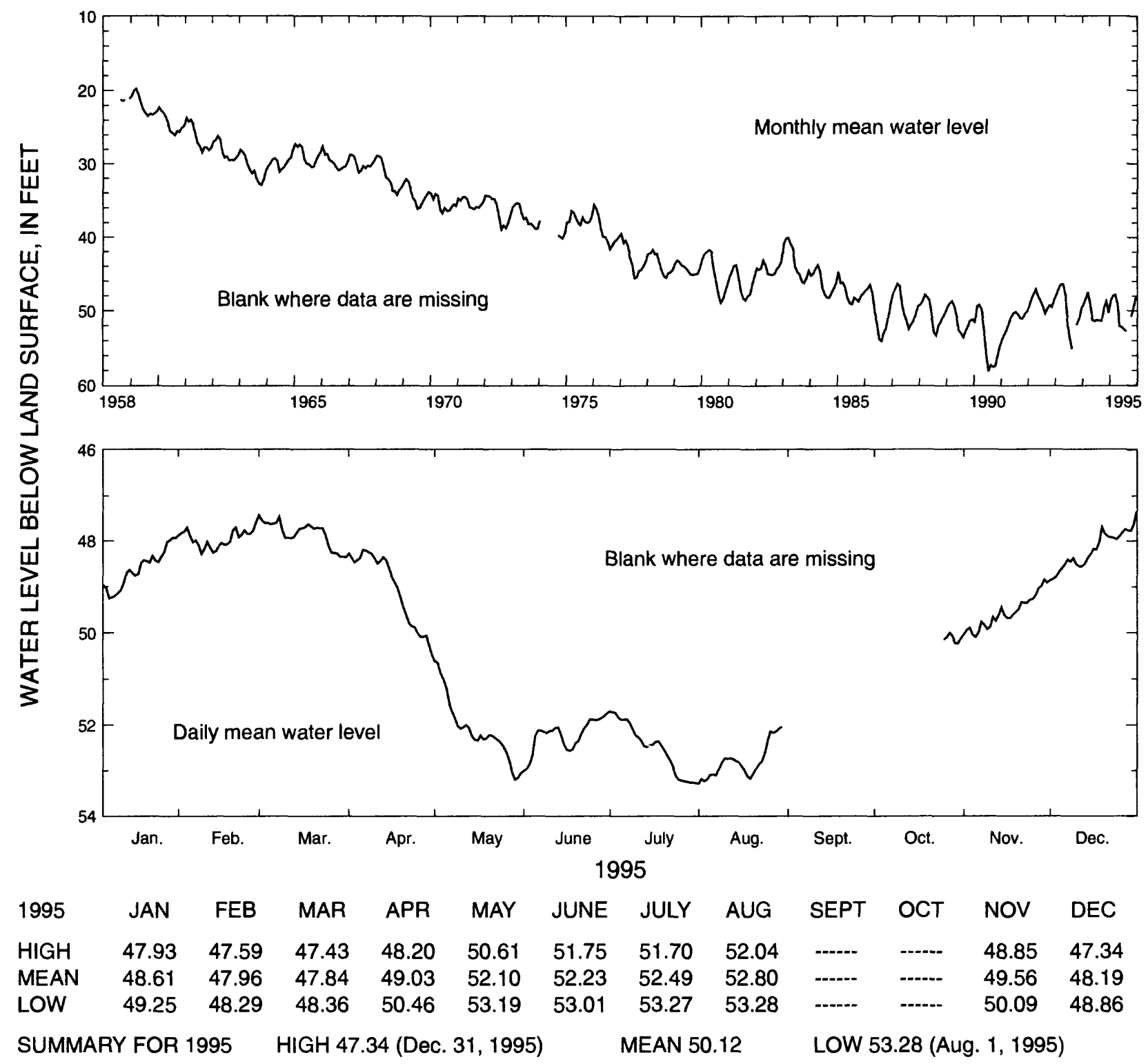

Figure 33.-Water level in observation well 36Q020, Chatham County. 
320202080541201 Local number, 38Q002.

LOCATION.-Lat $32^{\circ} 02^{\prime} 01^{\prime \prime}$, long $80^{\circ} 54^{\prime} 11^{\prime \prime}$, Hydrologic Unit 03060204.

SITE NAME.-National Park Service, test well 6.

INSTRUMENTATION.-Digital recorder.

AQUIFER.-Upper Floridan.

WELL CHARACTERISTICS. - Drilled observation well, diameter 8 in., depth $348 \mathrm{ft}$, cased to $110 \mathrm{ft}$, open hole.

DATUM.-Altitude of land-surface datum is $8.0 \mathrm{ft}$.

REMARKS.-Water levels for period, June 4-28, are missing.

PERIOD OF RECORD.-February 1956 to current year. Continuous record since February 1956.

EXTREMES FOR PERIOD OF RECORD.- Highest water level, $16.00 \mathrm{ft}$ below land-surface datum, March 5, 1956;

lowest, $40.69 \mathrm{ft}$ below land-surface datum, July 16, 1990.
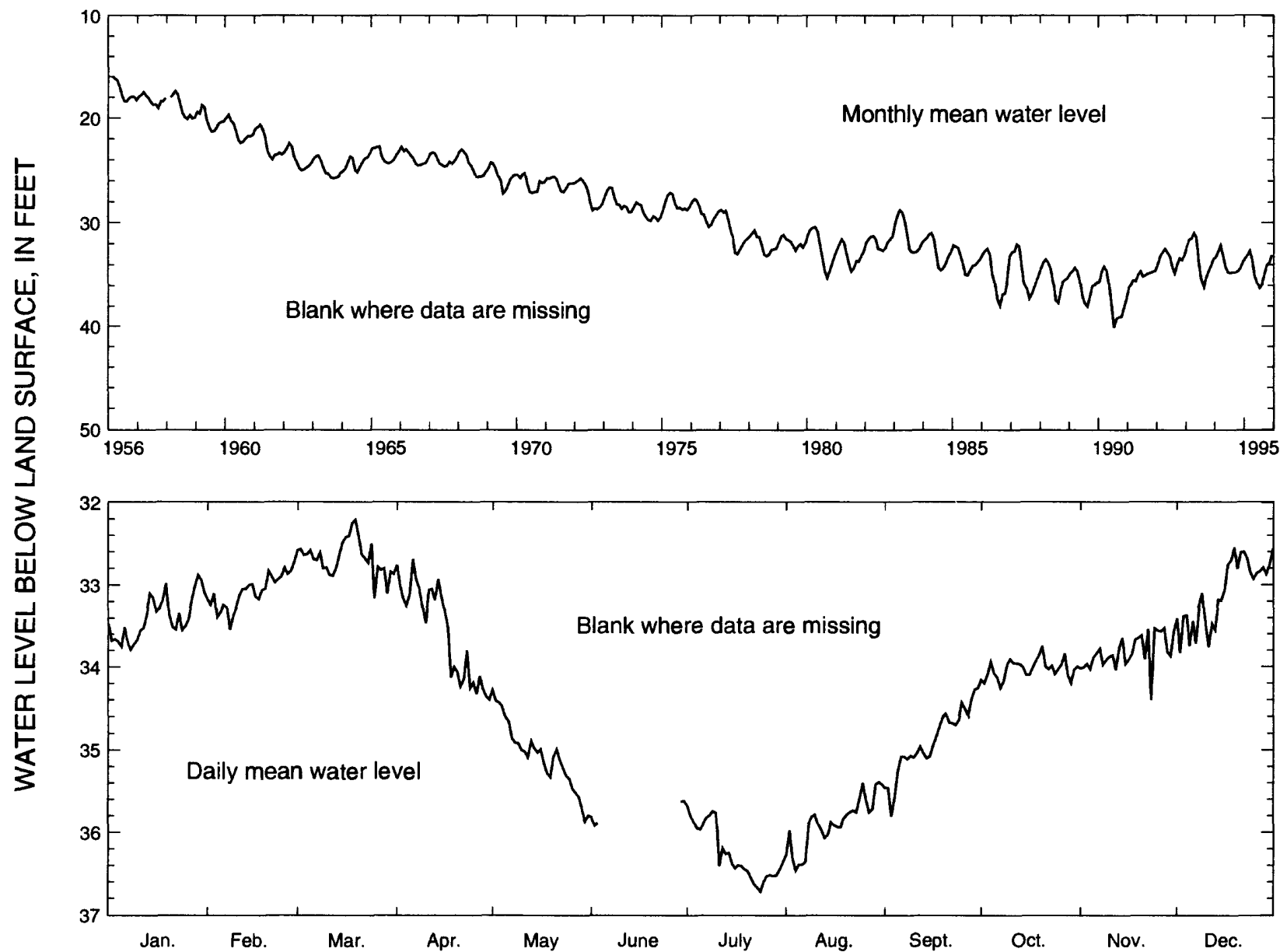

1995

$\begin{array}{lllllllllllll}1995 & \text { JAN } & \text { FEB } & \text { MAR } & \text { APR } & \text { MAY } & \text { JUNE } & \text { JULY } & \text { AUG } & \text { SEPT } & \text { OCT } & \text { NOV } & \text { DEC } \\ \text { HIGH } & 32.88 & 32.72 & 32.21 & 32.69 & 34.28 & -\ldots-.- & 35.68 & 35.39 & 34.26 & 33.75 & 33.53 & 32.55 \\ \text { MEAN } & 33.40 & 33.08 & 32.67 & 33.57 & 35.08 & -\ldots-- & 36.26 & 35.89 & 34.90 & 34.03 & 33.82 & 33.10 \\ \text { LOW } & 33.79 & 33.54 & 33.16 & 34.40 & 35.87 & -\cdots-- & 36.72 & 36.46 & 35.81 & 34.26 & 34.40 & 33.83\end{array}$

SUMMARY FOR 1995 HIGH 32.21 (Mar. 19, 1995) MEAN $34.20 \quad$ LOW 36.72 (July 24, 1995)

Figure 34.-Water level in observation well 38Q002, Chatham County. 
320122080510204 Local number, 390003.

LOCATION.-Lat $32^{\circ} 01^{\prime} 22^{\prime \prime}$, long $80^{\circ} 51^{\prime} 01^{\prime \prime}$, Hydrologic Unit 03060204.

SITE NAME.-U.S. Geological Survey, test well 7.

INSTRUMENTATION.-Digital recorder.

AQUIFER.-Upper Floridan.

WELL CHARACTERISTICS. -Drilled observation well, diameter $10 \mathrm{in}$., depth $600 \mathrm{ft}$, cased to $129 \mathrm{ft}$, open hole.

DATUM.-Altitude of land-surface datum is $7.0 \mathrm{ft}$.

REMARKS.-None.

PERIOD OF RECORD.-May 1962 to current year. Continuous record since December 1964.

EXTREMES FOR PERIOD OF RECORD. - Highest water level, $17.80 \mathrm{ft}$ below land-surface datum, April 11, 1963;

lowest, $36.07 \mathrm{ft}$ below land-surface datum, July 11-12, 1990.

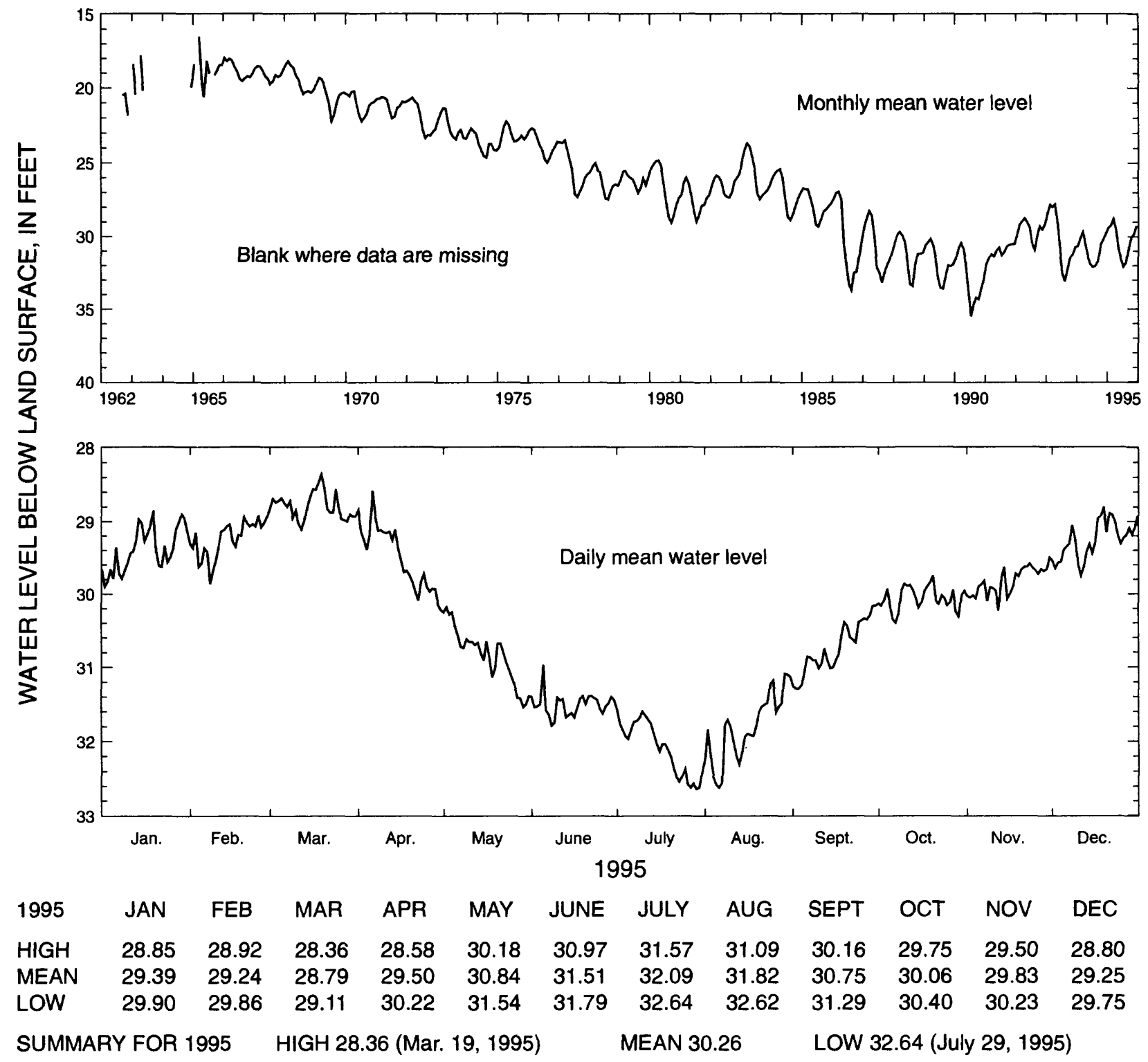

Figure 35.-Water level in observation well 39Q003, Chatham County. 
321240081411501 Local number, 32R002.

LOCATION. - Lat $32^{\circ} 12^{\prime} 40^{\prime \prime}$, long $81^{\circ} 41^{\prime} 15^{\prime \prime}$, Hydrologic Unit 03060202.

SITE NAME.-Georgia Geologic Survey, Bulloch South, test well 1.

INSTRUMENTATION.-Digital recorder.

AQUIFER.-Upper Floridan.

WELL CHARACTERISTICS. -Drilled observation well, diameter 6 in., depth $804 \mathrm{ft}$, cased to $420 \mathrm{ft}$, open hole.

DATUM.-Altitude of land-surface datum is $120 \mathrm{ft}$.

REMARKS.-None.

PERIOD OF RECORD.-February 1983 to current year. Continuous record since February 1983.

EXTREMES FOR PERIOD OF RECORD.-Highest water level, $85.08 \mathrm{ft}$ below land-surface datum, April 24, 1983;

lowest, $95.94 \mathrm{ft}$ below land-surface datum, October 8, 1990.
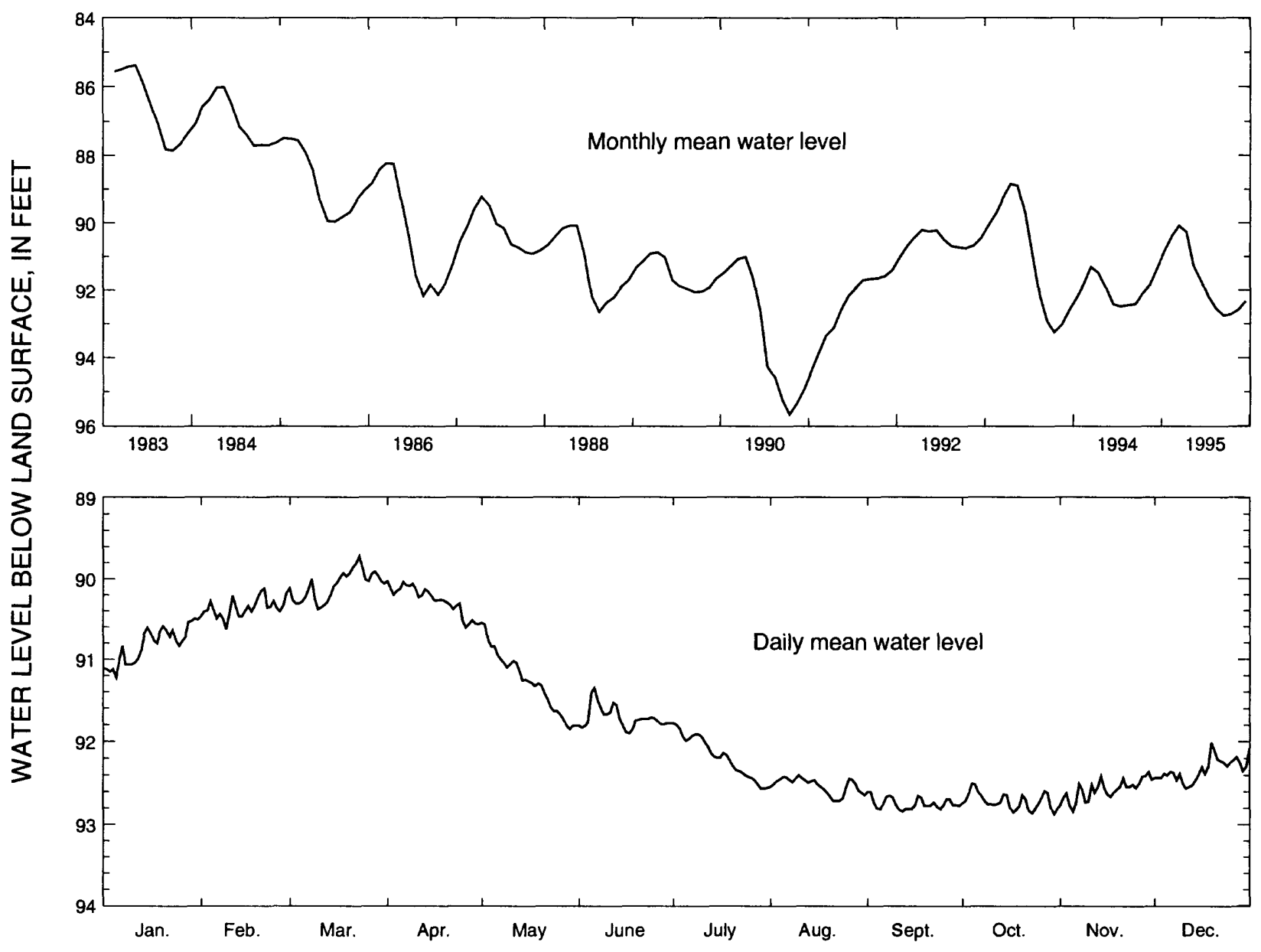

$\begin{array}{lcccccccccccc}1995 & \text { JAN } & \text { FEB } & \text { MAR } & \text { APR } & \text { MAY } & \text { JUNE } & \text { JULY } & \text { AUG } & \text { SEPT } & \text { OCT } & \text { NOV } & \text { DEC } \\ \text { HIGH } & 90.50 & 90.12 & 89.72 & 90.03 & 90.55 & 91.35 & 91.78 & 92.40 & 92.60 & 92.50 & 92.36 & 92.01 \\ \text { MEAN } & 90.83 & 90.37 & 90.08 & 90.27 & 91.27 & 91.71 & 92.18 & 92.53 & 92.74 & 92.72 & 92.58 & 92.33 \\ \text { LOW } & 91.22 & 90.63 & 90.38 & 90.61 & 91.85 & 91.90 & 92.56 & 92.71 & 92.84 & 92.87 & 92.84 & 92.56 \\ \text { SUMMARY FOR 1995 } & \text { HIGH } & 89.72(M a r .23,1995) & \text { MEAN } & 91.64 & \text { LOW } & 92.87 \text { (Oct. 30, 1995) }\end{array}$

Figure 36.-Water level in observation well 32R002, Bulloch County. 
315214081235301 Local number, 34N089.

LOCATION.-Lat $31^{\circ} 52^{\prime} 14^{\prime \prime}$, long $81^{\circ} 23^{\prime} 53^{\prime \prime}$, Hydrologic Unit 03060204.

SITE NAME.-U.S. Geological Survey, test well 1.

INSTRUMENTATION.-Digital recorder.

AQUIFER.-Upper Floridan.

WELL CHARACTERISTICS.-Drilled observation well, diameter 4 in., depth $789 \mathrm{ft}$, cased to $410 \mathrm{ft}$, open hole.

DATUM.-Altitude of land-surface datum is $17 \mathrm{ft}$.

REMARKS.-Water levels for periods, October 1-9 and November 26 to December 6, are missing.

PERIOD OF RECORD.-February 1967 to current year. Continuous record since February 1967.

EXTREMES FOR PERIOD OF RECORD. - Highest water level, $2.34 \mathrm{ft}$ below land-surface datum, March 6, 1967; lowest, $29.43 \mathrm{ft}$ below land-surface datum, October 3, 1990.

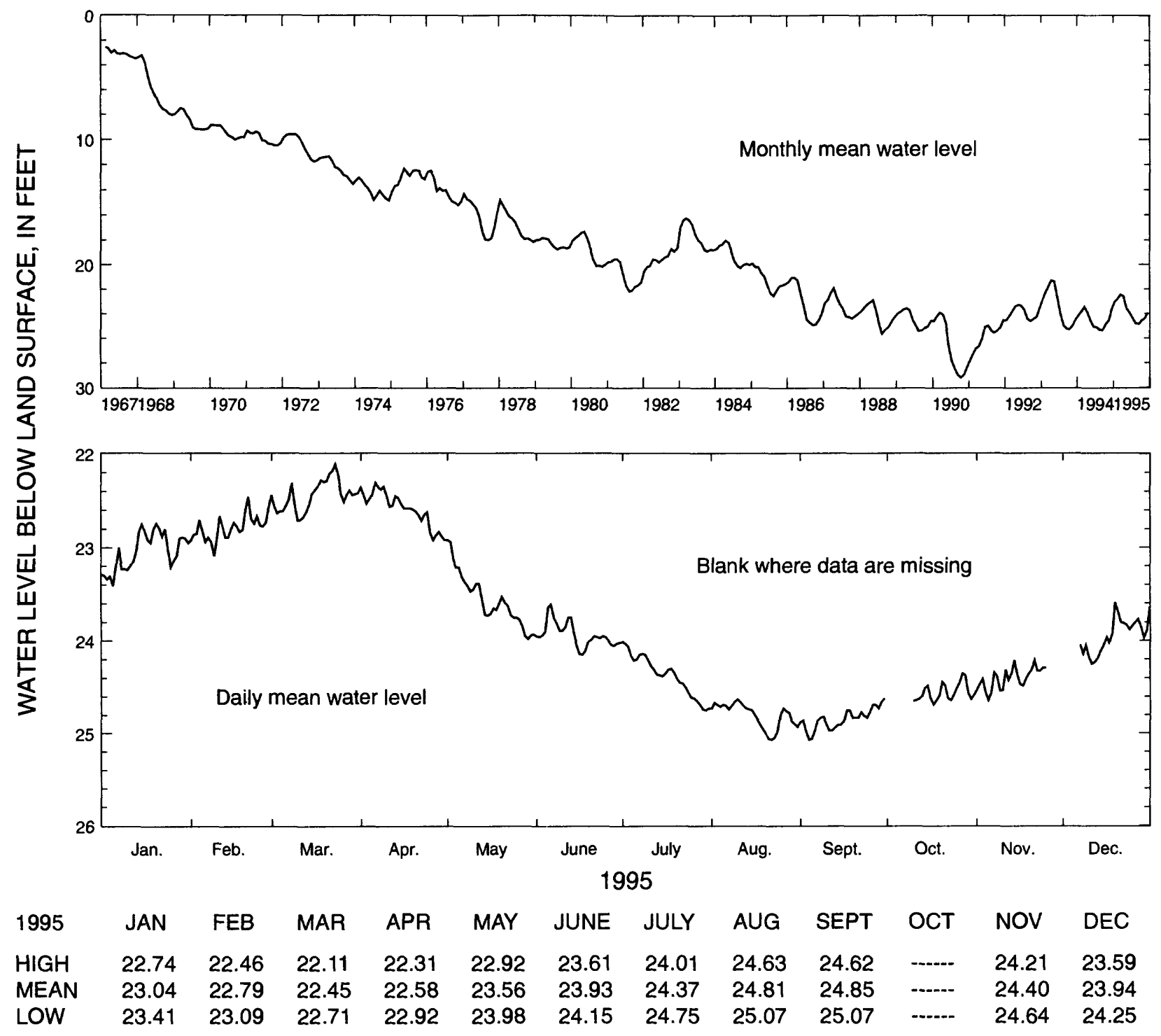

SUMMARY FOR 1995 HIGH 22.11 (Mar. 23, 1995) MEAN 23.75 LOW 25.07 (Aug. 22 and Sept. 4, 1995)

Figure 37.-Water level in observation well 34N089, Liberty County. 
313823081154201 Local number, 35M013.

LOCATION.-Lat $31^{\circ} 38^{\prime 2} 23^{\prime \prime}$, long 81 ${ }^{\circ} 15^{\prime} 42^{\prime \prime}$, Hydrologic Unit 03060204.

SITE NAME.-U.S. Fish and Wildlife Service.

INSTRUMENTATION.-Digital recorder.

AQUIFER.-Upper Floridan.

WELL CHARACTERISTICS.-Drilled unused supply well, diameter $10 \mathrm{in}$., depth $553 \mathrm{ft}$, cased to $376 \mathrm{ft}$, open hole.

DATUM.-Altitude of land-surface datum is $16.3 \mathrm{ft}$.

REMARKS. - Water levels for periods, September 21 to October 5 and December 7-31, are missing.

PERIOD OF RECORD. - September 1966 to current year. Continuous record since September 1966.

EXTREMES FOR PERIOD OF RECORD.-Highest water level, $4.35 \mathrm{ft}$ below land-surface datum, October 4, 1966; lowest, $26.88 \mathrm{ft}$ below land-surface datum, November 14, 1990.

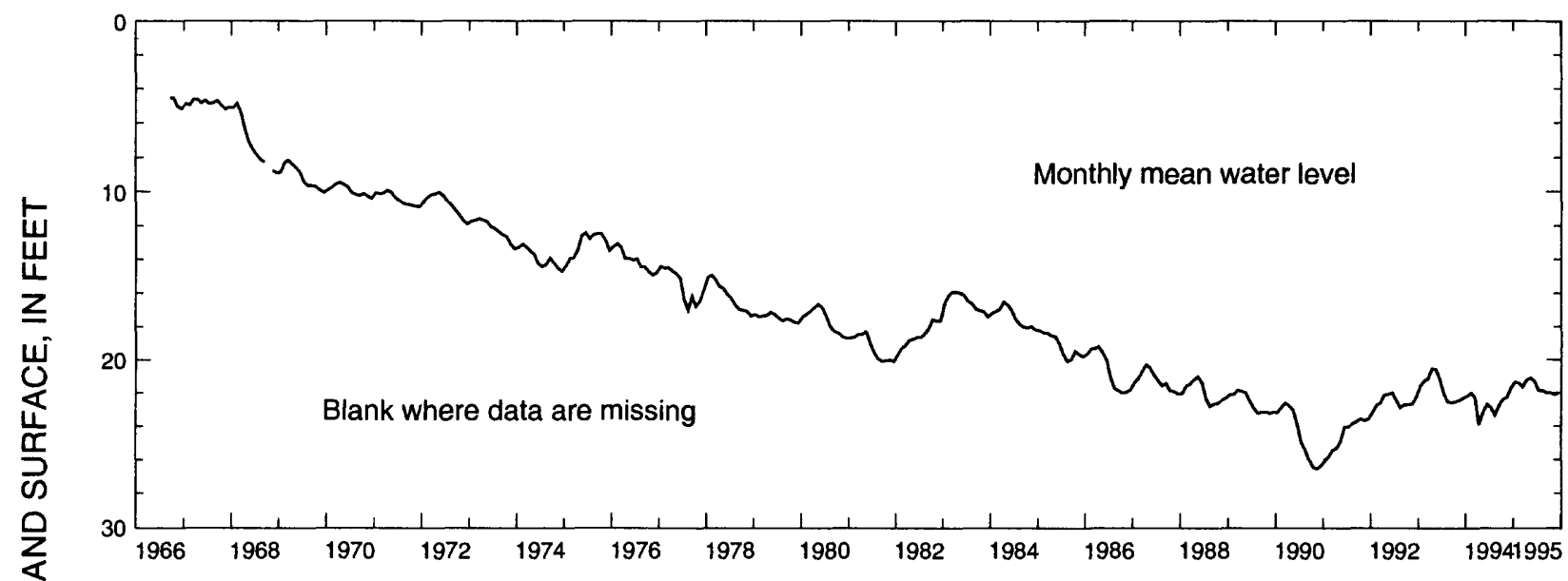

لب

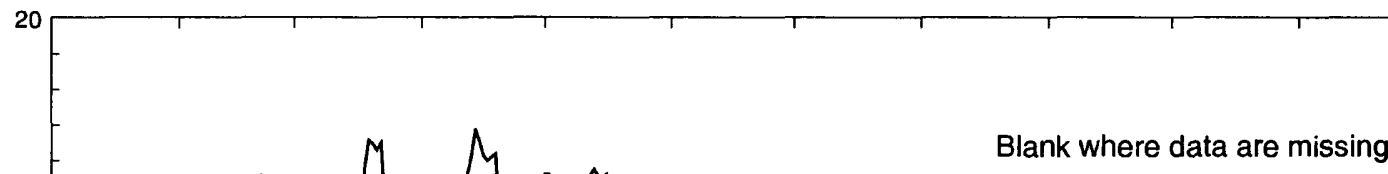

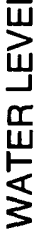

W

$M W^{M}$

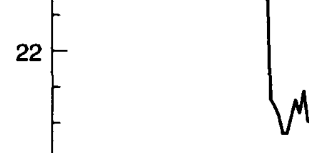

23

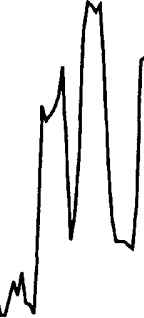

Daily mean water level

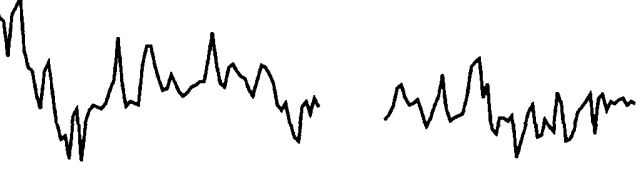

Jan.
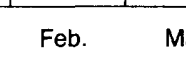

1995

JAN FE

FEB

MAR

APR

MAY

JUNE

HIGH

21.00

20.88

20.68

20.62

$20.85 \quad 20.91$

21.37

21.43

LOW

21.71

22.46

21.65

22.45

21.25

21.12

21.31

22.07

22.18

21.73

HIGH 20.62 (Apr. 14, 1995)

MEAN 21.63

AUG SEPT OCT NOV DEC

SUMMARY FOR 1995

21.33

21.87

21.62

21.88

22.04

$-\cdots---\quad 21.77 \quad 21.96$

$\begin{array}{lll}-----\quad 22.00 & 22.11\end{array}$

$-\cdots--\quad 22.15 \quad 22.32$

LOW 22.46 (Feb. 26-27, 1995)

Figure 38.-Water level in observation well 35M013, McIntosh County. 
313701081543501 Local number, 30 L003.

LOCATION.-Lat $31^{\circ} 37^{\prime} 01^{\prime \prime}$, long $81^{\circ} 54^{\prime} 34^{\prime \prime}$, Hydrologic Unit 03070106.

SITE NAME.-City of Jesup Housing Authority.

INSTRUMENTATION.-Analog recorder.

AQUIFER.-Upper Floridan.

WELL CHARACTERISTICS. - Drilled unused supply well, diameter 4 in., depth $584 \mathrm{ft}$, cased to $472 \mathrm{ft}$, open hole.

DATUM.-Altitude of land-surface datum is $107 \mathrm{ft}$.

REMARKS. - Water levels for period, August 11 to September 7 , are missing.

PERIOD OF RECORD.-January 1964 to current year. Continuous record January 1964 to March 1967, and since January 1976.

EXTREMES FOR PERIOD OF RECORD. - Highest water level, $59.98 \mathrm{ft}$ below land-surface datum, April 19, 1964; lowest, $88.91 \mathrm{ft}$ below land-surface datum, October 7, 1990.
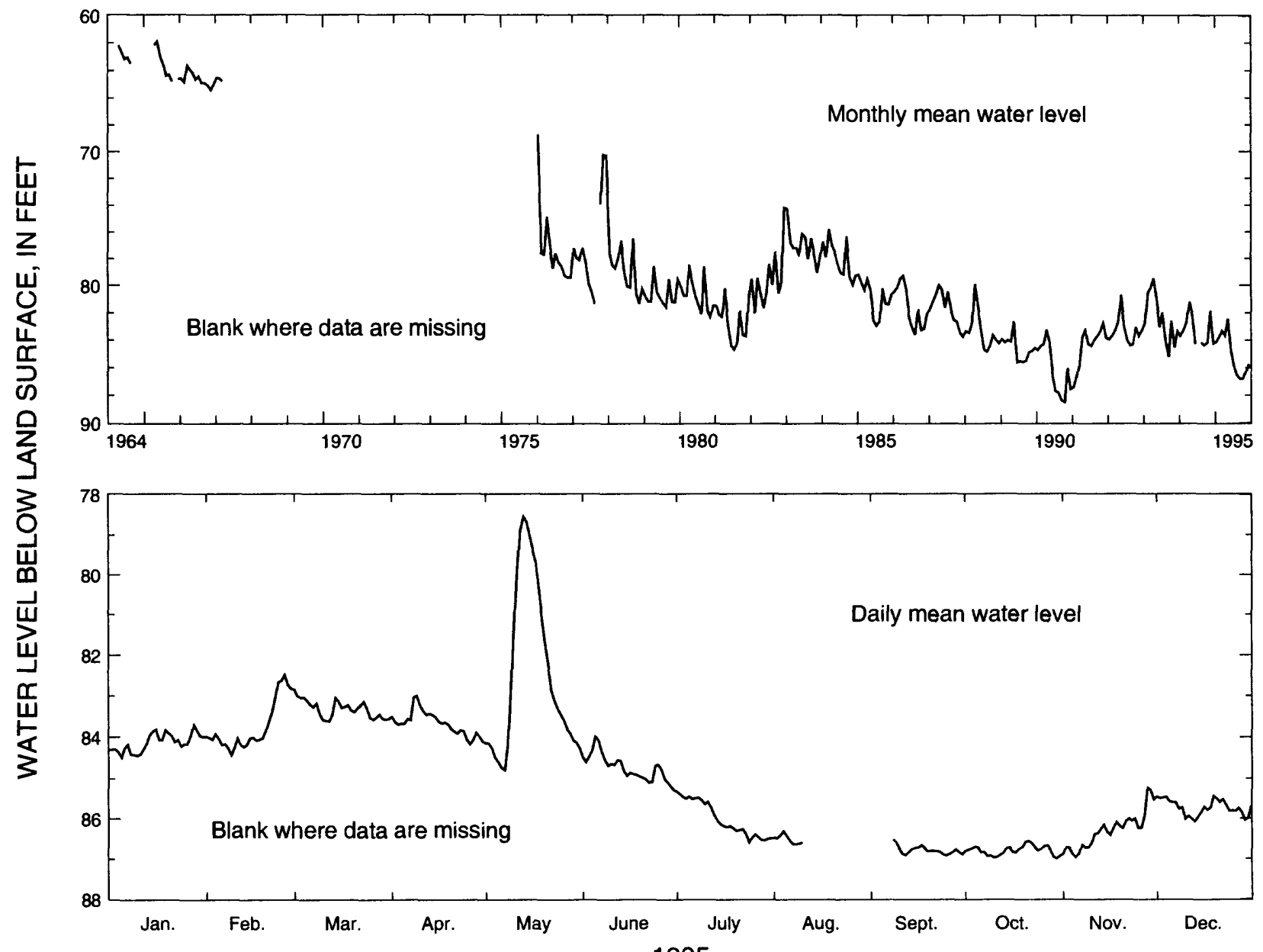

\begin{tabular}{|c|c|c|c|c|c|c|c|c|c|c|c|c|}
\hline 1995 & JAN & FEB & MAR & APR & MAY & JUNE & JULY & AUG & SEPT & OCT & NOV & DEC \\
\hline$G$ & 83.70 & 82.48 & 82.84 & 83.00 & 78.55 & 83.99 & 85.32 & -..-- & -.-- & 86.56 & 85.24 & 85.44 \\
\hline & 84.13 & 83.7 & 83.32 & 83.66 & 82.44 & 84 & 86 & -...-.. & -..--..- & 86.79 & 86.30 & 85.73 \\
\hline DW & 84.49 & 84.43 & 83.61 & 84.17 & 84.79 & 85.28 & 86.59 & --.-- & ----- & 87.00 & 86.96 & 86.07 \\
\hline IMA & ? & & & 5 & 13 & & $=\pi$ & .89 & LOW & 7.0 & 30 & \\
\hline
\end{tabular}

Figure 39.-Water level in observation well 30L003, Wayne County. 
313253081433502 Local number, 32L015.

LOCATION.-Lat $31^{\circ} 32^{\prime} 52^{\prime \prime}$, long 81 $81^{\circ} 43^{\prime \prime}$, Hydrologic Unit 03070106.

SITE NAME.-Georgia Geologic Survey, Gardi, test well 1.

INSTRUMENTATION.-Digital recorder.

AQUIFER.-Upper Floridan.

WELL CHARACTERISTICS. - Drilled observation well, diameter 4 in., depth $750 \mathrm{ft}$, cased to $545 \mathrm{ft}$, open hole.

DATUM.-Altitude of land-surface datum is $74 \mathrm{ft}$.

REMARKS.-None.

PERIOD OF RECORD. June 1983 to current year. Continuous record since June 1983.

EXTREMES FOR PERIOD OF RECORD. - Highest water level, $49.12 \mathrm{ft}$ below land-surface datum, March 19, 1984; lowest, $64.05 \mathrm{ft}$ below land-surface datum, October 7-8, 1990.

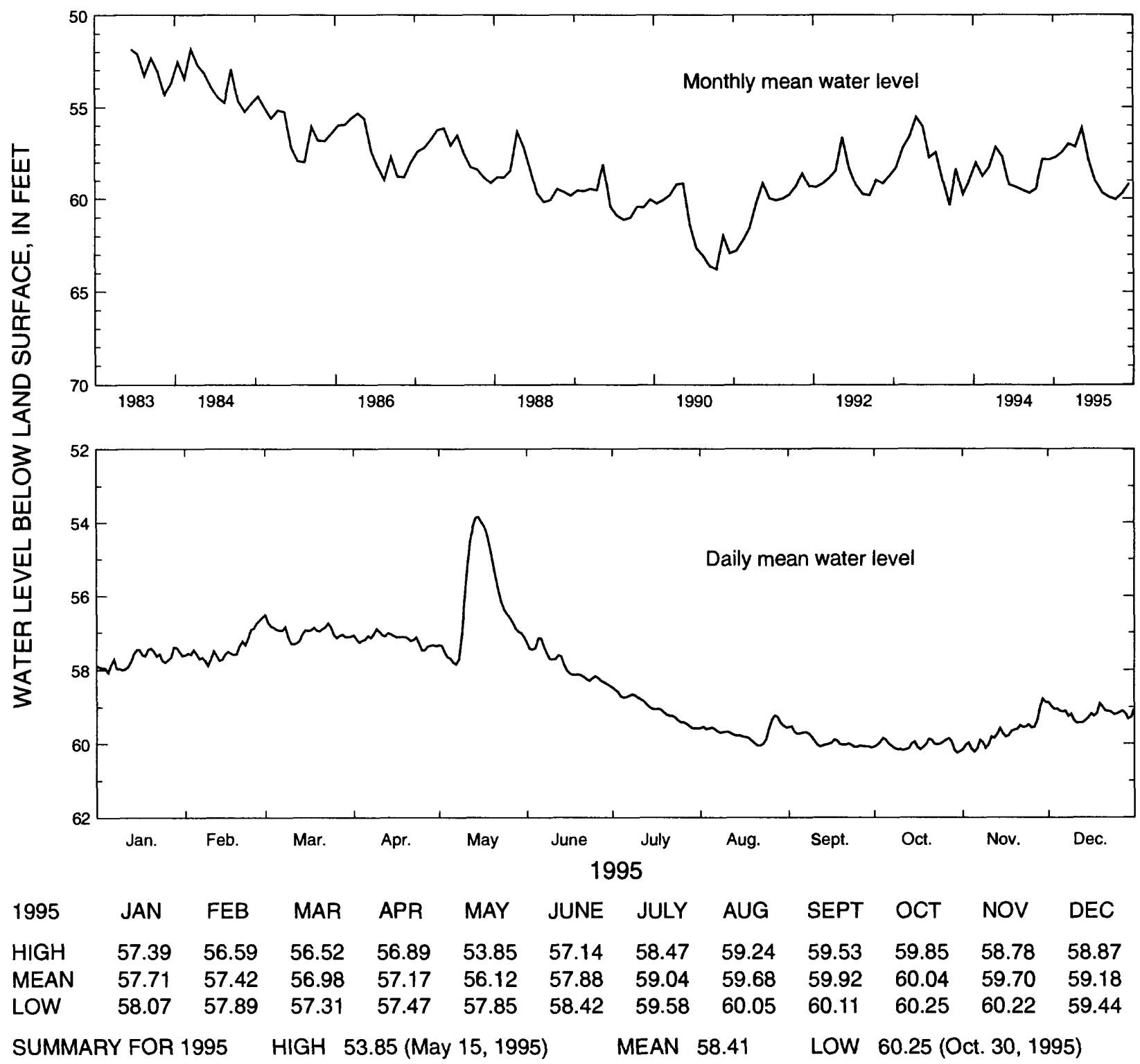

Figure 40.-Water level in observation well 32L015, Wayne County. 
313845081361701 Local number, 33M004.

LOCATION.-Lat $31^{\circ} 38^{\prime} 54^{\prime \prime}$, long $81^{\circ} 36^{\prime} 04^{\prime \prime}$, Hydrologic Unit 03070106.

SITE NAME.-U.S. Geological Survey, test well 3.

INSTRUMENTATION.-Digital recorder.

AQUIFER.-Upper Floridan.

WELL CHARACTERISTICS.-Drilled observation well, diameter 4-3 in., depth $872 \mathrm{ft}$, cased to $538 \mathrm{ft}$, open hole.

DATUM.-Altitude of land-surface datum is $61.2 \mathrm{ft}$.

REMARKS.-None.

PERIOD OF RECORD.—January 1968 to current year. Continuous record since January 1968.

EXTREMES FOR PERIOD OF RECORD. - Highest water level, $34.04 \mathrm{ft}$ below land-surface datum, January 14, 1968;

lowest, $59.00 \mathrm{ft}$ below land-surface datum, October 8, 1990.

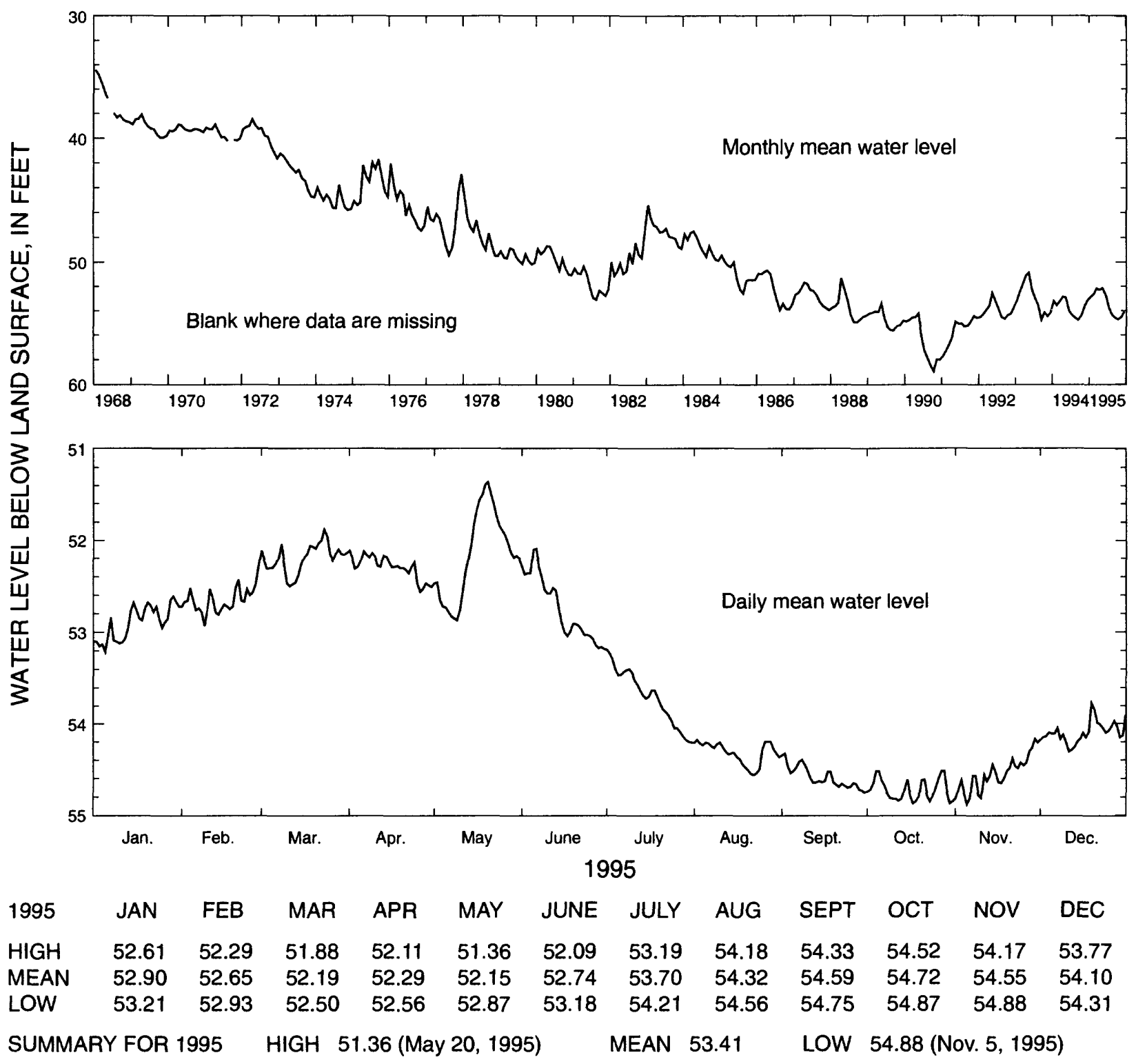

Figure 41.-Water level in observation well 33M004, Long County. 
311007081301701 Local number, 33H127.

LOCATION. - Lat $31^{\circ} 10^{\prime} 06^{\prime \prime}$, long $81^{\circ} 30^{\prime} 16^{\prime \prime}$, Hydrologic Unit 03070203.

SITE NAME.-U.S. Geological Survey, test well 3.

INSTRUMENTATION.-Digital recorder.

AQUIFER.-Upper Floridan; lower water-bearing zone.

WELL CHARACTERISTICS.-Drilled observation well, diameter 4 in., depth 1,002 ft, cased to $823 \mathrm{ft}$, open hole.

DATUM.-Altitude of land-surface datum is $6.2 \mathrm{ft}$.

REMARKS. -Well pumped and sampled for analysis of chloride concentration semi-annually. Water levels for period, June 29 to July 25, are missing.

PERIOD OF RECORD.-August 1962 to current year. Continuous record since August 1962.

EXTREMES FOR PERIOD OF RECORD.-Highest water level, $14.00 \mathrm{ft}$ above land-surface datum, October 9, 1962; lowest, $13.22 \mathrm{ft}$ below land-surface datum, July 9, 1990.

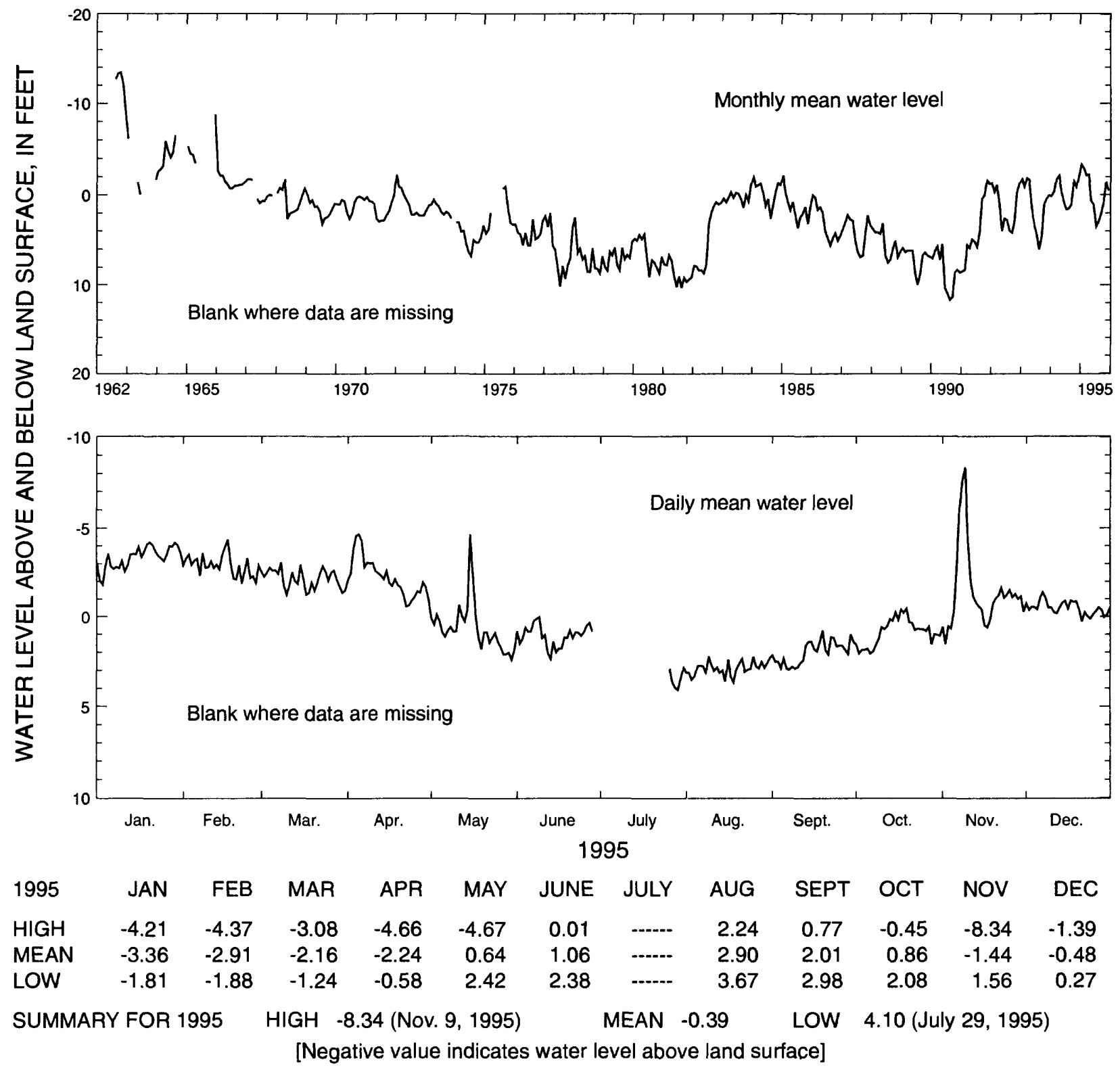

Figure 42.-Water level in observation well 33H127, Glynn County. 
310822081294201 Local number, $34 \mathrm{H} 403$.

LOCATION.-Lat $31^{\circ} 08^{\prime} 22^{\prime \prime}$, long $81^{\circ} 29^{\prime} 42^{\prime \prime}$, Hydrologic Unit 03070203.

SITE NAME. -U.S. Geological Survey, test well 24.

INSTRUMENTATION.-Digital recorder.

AQUIFER. -Upper Floridan; lower water-bearing zone.

WELL CHARACTERISTICS. - Drilled observation well, diameter 4 in., depth $982 \mathrm{ft}$, cased to $788 \mathrm{ft}$, open hole.

DATUM.-Altitude of land-surface datum is $9.6 \mathrm{ft}$.

REMARKS. - Well pumped and sampled for analysis of chloride concentration semi-annually.

PERIOD OF RECORD.-August 1974 to current year. Continuous record since August 1974.

EXTREMES FOR PERIOD OF RECORD. - Highest water level, $12.79 \mathrm{ft}$ above land-surface datum, December 29,

1985; lowest, $4.76 \mathrm{ft}$ below land-surface datum, September 14, 1990.
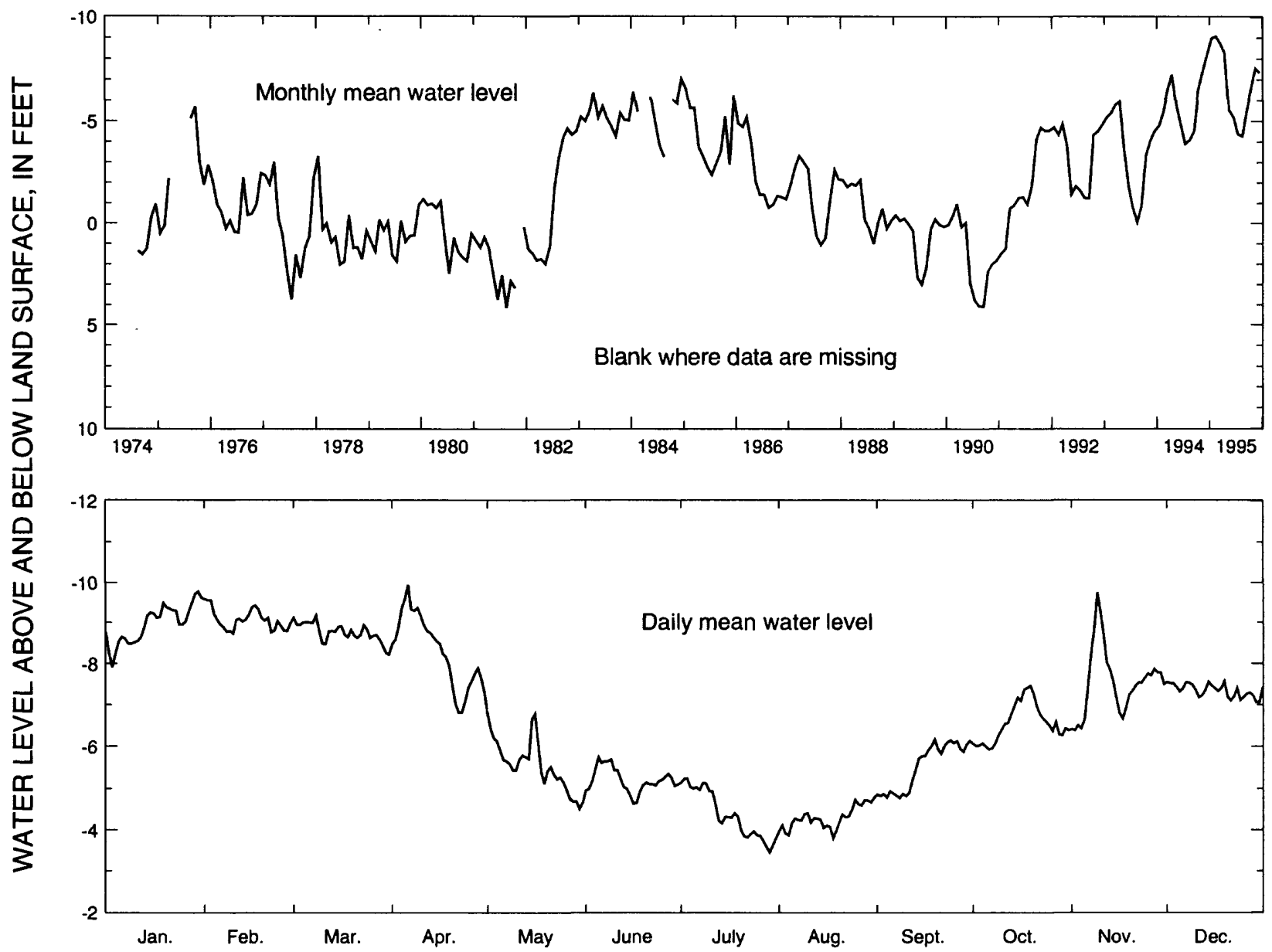

\begin{tabular}{lcccccccccccc}
1995 & JAN & FEB & MAR & APR & MAY & JUNE & JULY & AUG & SEPT & OCT & NOV & DEC \\
HIGH & -9.78 & -9.59 & -9.18 & -9.95 & -6.80 & -5.74 & -5.24 & -4.78 & -6.17 & -7.46 & -9.76 & -7.57 \\
MEAN & -8.97 & -9.08 & -8.76 & -8.31 & -5.56 & -5.19 & -4.38 & -4.29 & -5.51 & -6.55 & -7.55 & -7.35 \\
LOW & -7.91 & -8.73 & -8.22 & -6.81 & -4.50 & -4.63 & -3.45 & -3.80 & -4.77 & -5.93 & -6.38 & -7.06 \\
SUMMARY FOR 1995 & \multicolumn{3}{c}{ HIGH -9.95 (Apr. 6, 1995) } \\
[Negative value indicates water level above land surface] &
\end{tabular}

Figure 43.-Water level in observation well $34 \mathrm{H} 403$, Glynn County. 
311007081301702 Local number, $33 \mathrm{H} 133$.

LOCATION.-Lat $31^{\circ} 10^{\prime} 08^{\prime \prime}$, long 81 $31^{\prime} 16^{\prime \prime}$, Hydrologic Unit 03070203.

SITE NAME.-U.S. Geological Survey, test well 6.

INSTRUMENTATION.-Digital recorder.

AQUIFER.-Upper Floridan; upper water-bearing zone.

WELL CHARACTERISTICS.-Drilled observation well, diameter 4 in., depth $790 \mathrm{ft}$, cased to $520 \mathrm{ft}$, open hole.

DATUM.-Altitude of land-surface datum is $6.7 \mathrm{ft}$.

REMARKS.-Well pumped and sampled for analysis of chloride concentration semi-annually. Water levels for period, June 29 to July 25, are missing.

PERIOD OF RECORD. - January 1963 to current year. Continuous record since January 1963.

EXTREMES FOR PERIOD OF RECORD.-Highest water level, $9.07 \mathrm{ft}$ above land-surface datum, December 26 , 1965; lowest, $21.87 \mathrm{ft}$ below land-surface datum, July 22, 1977.
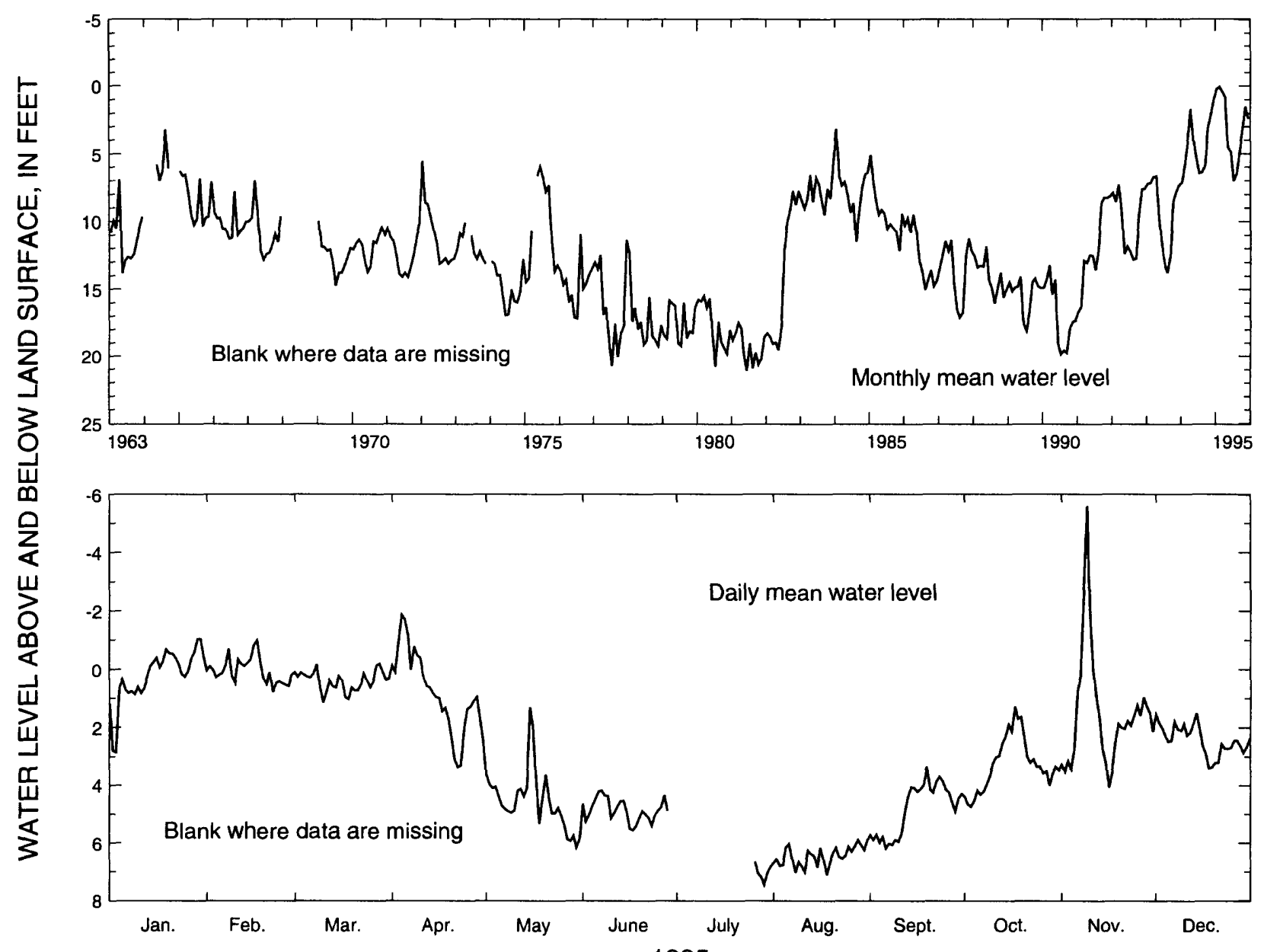

\begin{tabular}{|c|c|c|c|c|c|c|c|c|c|c|c|c|}
\hline 1995 & JAN & FEB & MAR & APR & MAY & JUNE & JULY & $A \cup G$ & SEPT & OCT & NOV & DEC \\
\hline HIGH & $\begin{array}{r}-1.04 \\
\end{array}$ & $\begin{array}{r}-0.99 \\
\end{array}$ & -0.19 & $\begin{array}{r}-1.87 \\
\end{array}$ & 1.30 & 4.18 & ------ & 5.90 & 3.35 & 1.27 & $\begin{array}{r}-5.61 \\
\end{array}$ & 1.50 \\
\hline $\begin{array}{l}\text { MEAN } \\
\text { LOW }\end{array}$ & $\begin{array}{l}0.23 \\
2.85\end{array}$ & $\begin{array}{l}0.05 \\
0.78\end{array}$ & $\begin{array}{l}0.40 \\
1.15\end{array}$ & $\begin{array}{l}0.80 \\
3.36\end{array}$ & $\begin{array}{l}4.54 \\
6.16\end{array}$ & $\begin{array}{l}4.86 \\
5.56\end{array}$ & --.-. & $\begin{array}{l}6.46 \\
7.11\end{array}$ & $\begin{array}{l}4.81 \\
6.19\end{array}$ & $\begin{array}{l}3.26 \\
4.74\end{array}$ & $\begin{array}{l}1.51 \\
4.07\end{array}$ & $\begin{array}{l}2.42 \\
3.40\end{array}$ \\
\hline III & Ur & & & 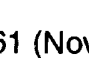 & 35) & & MEAN & 2.75 & LOW & 7.46 (J & 29,19 & \\
\hline
\end{tabular}

Figure 44.-Water level in observation well $33 \mathrm{H} 133$, Glynn County. 
310818081293701 Local number, $34 \mathrm{H} 371$.

LOCATION.-Lat $31^{\circ} 08^{\prime} 18^{\prime \prime}$, long $81^{\circ} 30^{\prime} 16^{\prime \prime}$, Hydrologic Unit 03070203.

SITE NAME.-U.S. Geological Survey, test well 11.

INSTRUMENTATION.-Digital recorder.

AQUIFER.-Upper Floridan; upper water-bearing zone.

WELL CHARACTERISTICS.-Drilled observation well, diameter $3-2$ in., depth $719 \mathrm{ft}$, cased to $512 \mathrm{ft}$, open hole.

DATUM.-Altitude of land-surface datum is $9.8 \mathrm{ft}$.

REMARKS.-Well pumped and sampled for analysis of chloride concentration semi-annually. Water levels for periods, January 3 to February 13 and August 20 to November 19, are missing.

PERIOD OF RECORD. - January 1967 to current year. Continuous record since January 1967.

EXTREMES FOR PERIOD OF RECORD.-Highest water level, $9.95 \mathrm{ft}$ above land-surface datum, March 18-19, 1967; lowest, $5.64 \mathrm{ft}$ below land-surface datum, September 14, 1990.
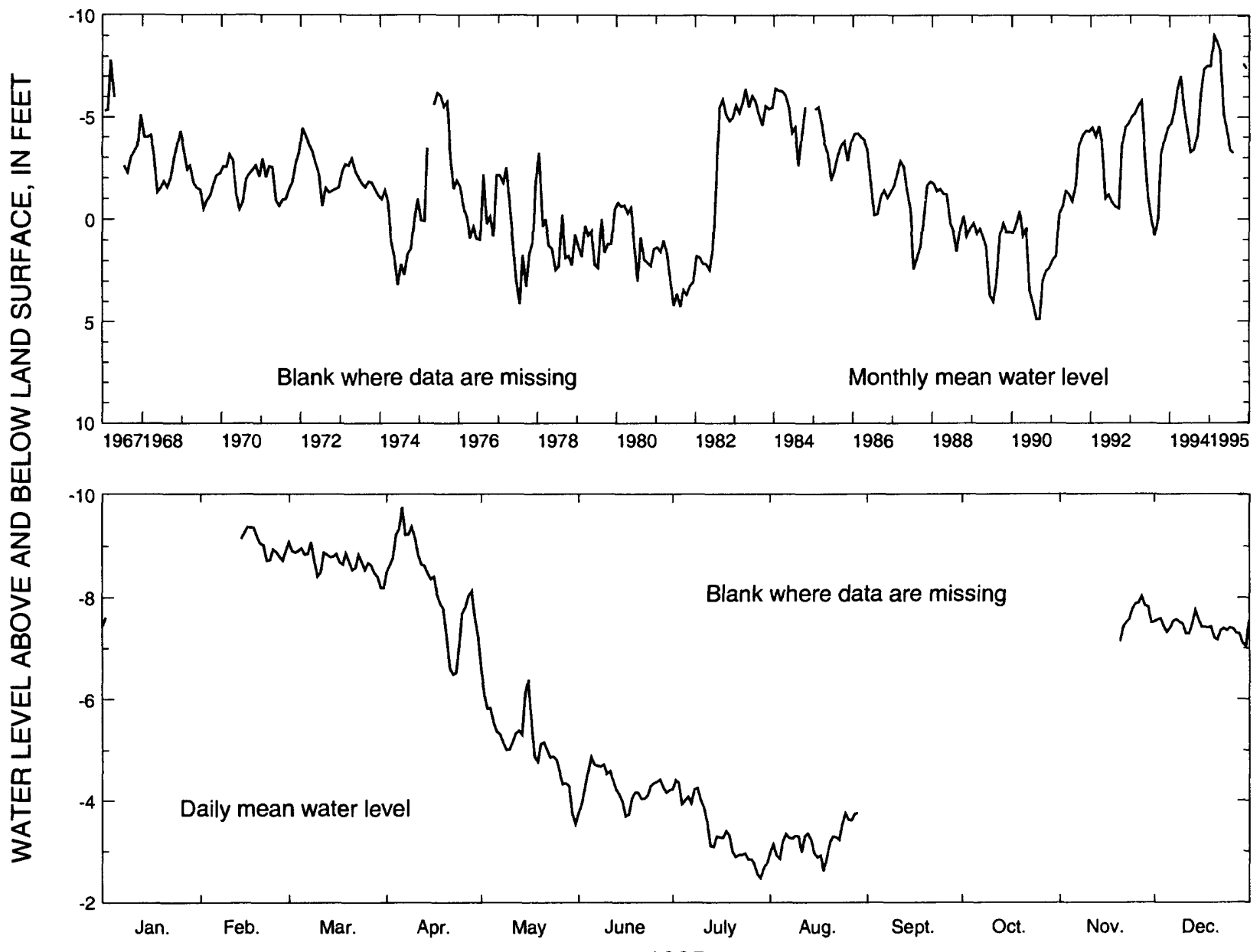

1995 JAN FEB MAR APR MAY JUNE JULY AUG SEPT OCT NOV DEC

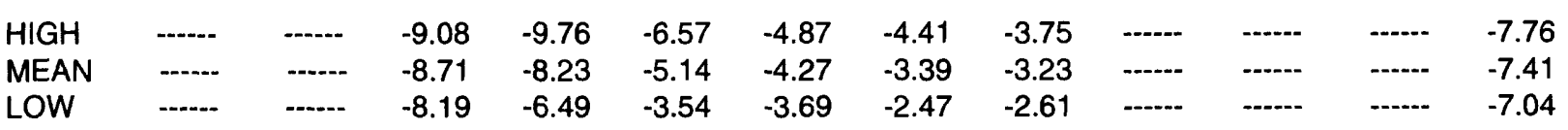

SUMMARY FOR 1995 HIGH -9.76 (Apr. 6, 1995) MEAN $-6.09 \quad$ LOW -2.47 (July 29, 1995)

[Negative value indicates water level above land surface]

Figure 45.-Water level in observation well 34H371, Glynn County. 
304756081311101 Local number, 33E027.

LOCATION.-Lat $30^{\circ} 47^{\prime} 56^{\prime \prime}$, long $81^{\circ} 31^{\prime} 11^{\prime \prime}$, Hydrologic Unit 03070203.

SITE NAME.-U.S. Navy, Kings Bay, test well 1.

INSTRUMENTATION.-Electronic data recorder.

AQUIFER.-Upper Floridan.

WELL CHARACTERISTICS.-Drilled test well, diameter 8 in., depth $1,306 \mathrm{ft}$, cased to $555 \mathrm{ft}$, backfilled to $990 \mathrm{ft}$, open hole.

DATUM.-Altitude of land-surface datum is $10.0 \mathrm{ft}$.

REMARKS.-None.

PERIOD OF RECORD.-August 1979 to current year. Continuous record since August 1979.

EXTREMES FOR PERIOD OF RECORD.- Highest water level, $24.71 \mathrm{ft}$ above land-surface datum, March 28, 1984, and March 17, 1983; lowest, $13.90 \mathrm{ft}$ above land-surface datum, June 10-11, 1985.
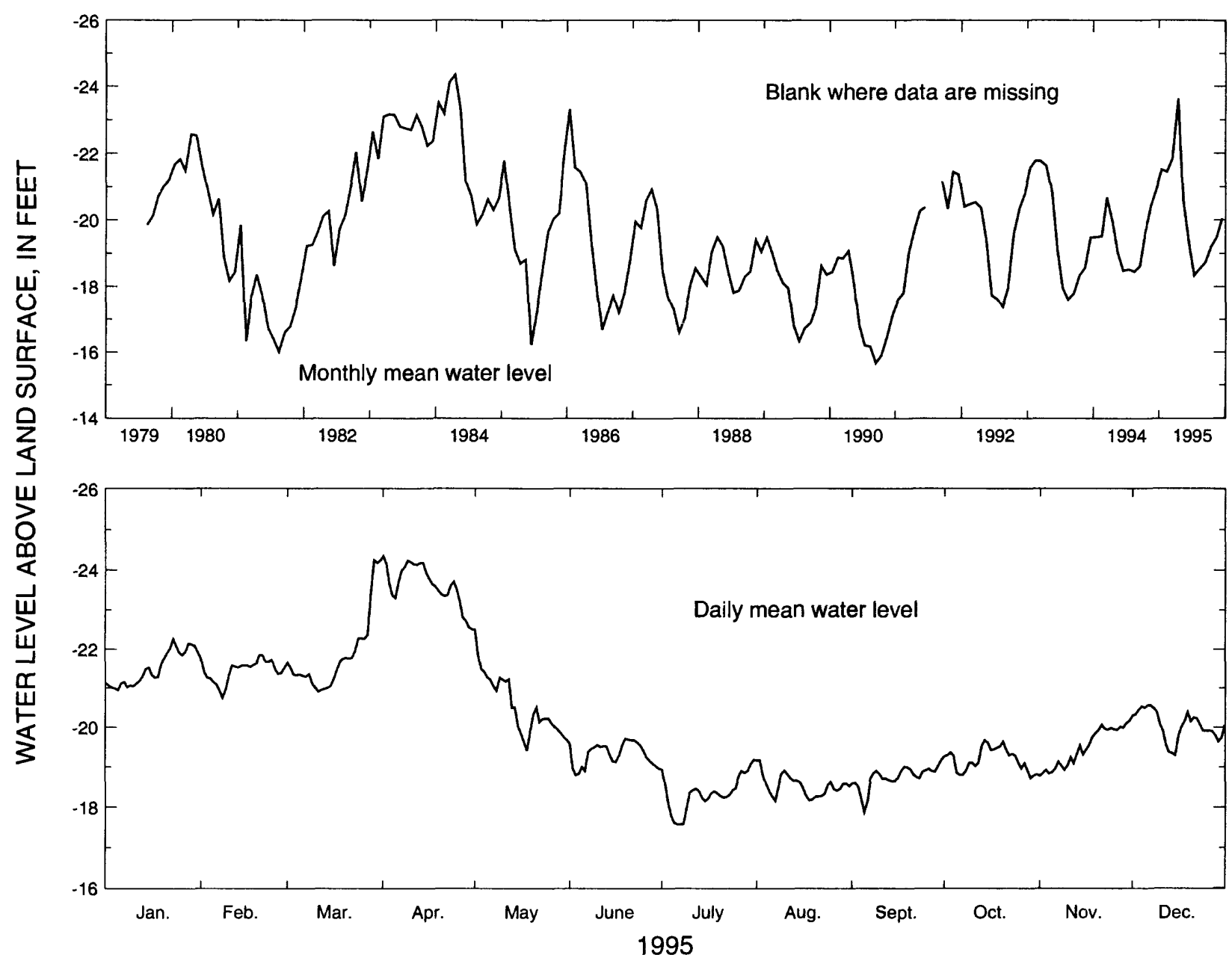

\begin{tabular}{|c|c|c|c|c|c|c|c|c|c|c|c|c|}
\hline 1995 & JAN & FEB & MAR & APR & MAY & JUNE & JULY & AUG & SEPT & OCT & NOV & DEC \\
\hline $\mathrm{HIGH}$ & -22.27 & -21.85 & -24.25 & -24.35 & -22.51 & -19.71 & -19.17 & -19.16 & -19.17 & -19.67 & -20.16 & -20.56 \\
\hline MEAN & -21.51 & -21.45 & -21.84 & -23.63 & -20.56 & -19.32 & -18.34 & -18.54 & -18.74 & -19.19 & -19.48 & -20.05 \\
\hline LOW & -20.95 & -20.75 & -20.91 & -22.52 & -19.41 & -18.79 & -17.57 & -18.16 & -17.88 & -18.72 & -18.77 & -19.29 \\
\hline \multicolumn{3}{|c|}{ SUMMARY FOR 1995} & IC & & 5) & & MEAD & & LOW & & 61 & \\
\hline
\end{tabular}

Figure 46. -Water level in observation well 33E027, Camden County. 
304942082213801 Local number, 27 E004.

LOCATION.-Lat $30^{\circ} 49^{\prime} 43^{\prime \prime}$, long 82'21'38', Hydrologic Unit 03110201.

SITE NAME.-U.S. Geological Survey, test well OK-9.

INSTRUMENTATION.-Digital recorder.

AQUIFER.-Upper Floridan.

WELL CHARACTERISTICS.-Drilled observation well, diameter 4 in., depth $700 \mathrm{ft}$, cased to $498 \mathrm{ft}$, open hole.

DATUM.-Altitude of land-surface datum is $116 \mathrm{ft}$.

REMARKS.-Well drilled in May 1978 to replace USGS test well OK-8 (27E002).

PERIOD OF RECORD.-May 1978 to current year. Continuous record since June 1980.

EXTREMES FOR PERIOD OF RECORD. - Highest water level, $62.30 \mathrm{ft}$ below land-surface datum, May 9, 1984;

lowest, $73.91 \mathrm{ft}$ below land-surface datum, October 7-8, 1990.

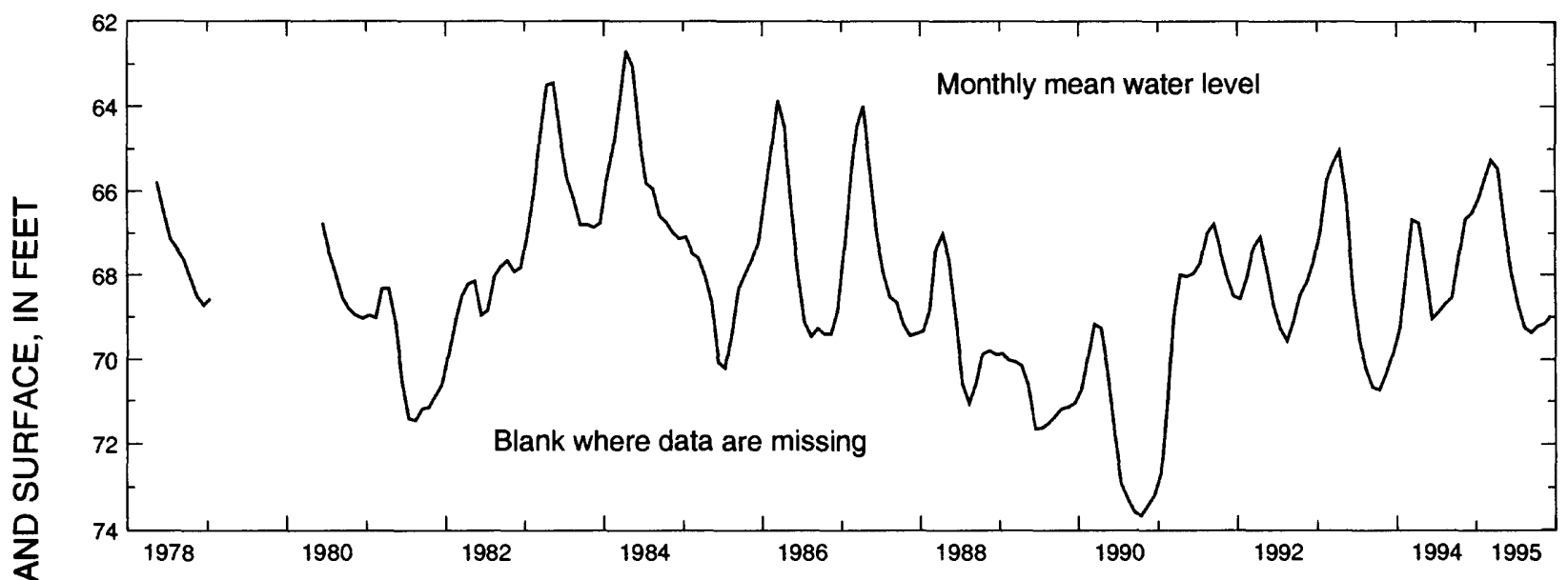

崖

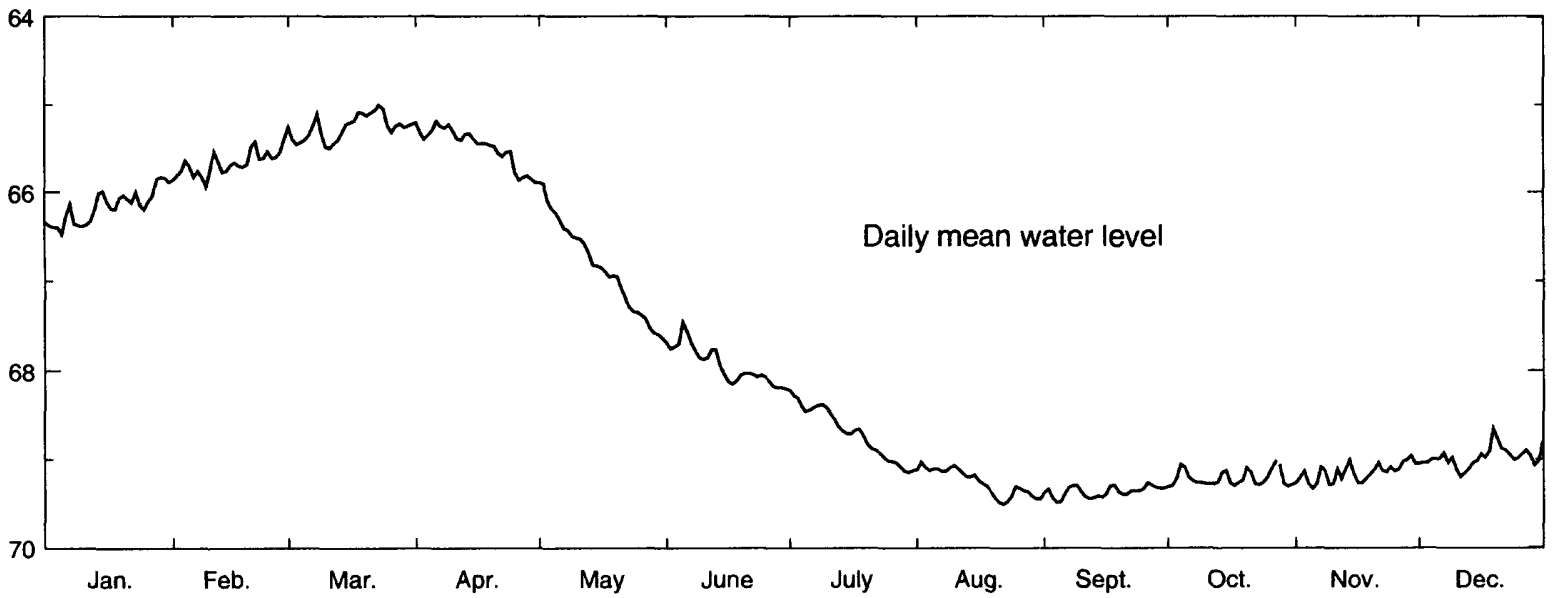

1995

1995 JAN FEB MAR APR MAY JUNE JULY AUG SEPT OCT NOV DEC

$\begin{array}{lllllllllllll}\text { HIGH } & 65.83 & 65.39 & 65.00 & 65.18 & 65.89 & 67.45 & 68.22 & 69.03 & 69.27 & 69.03 & 68.96 & 68.65 \\ \text { MEAN } & 66.17 & 65.67 & 65.25 & 65.47 & 66.83 & 67.93 & 68.70 & 69.26 & 69.37 & 69.22 & 69.16 & 68.98 \\ \text { LOW } & 66.48 & 65.94 & 65.49 & 65.89 & 67.63 & 68.20 & 69.15 & 69.51 & 69.49 & 69.31 & 69.34 & 69.20\end{array}$

SUMMARY FOR 1995 HIGH 65.00 (Mar. 23, 1995) MEAN $67.68 \quad$ LOW 69.51 (Aug. 22, 1995)

Figure 47.-Water level in observation well 27E004, Charlton County. 


\section{Lower Floridan aquifer in the Brunswick area}

The water level in the Lower Floridan aquifer was monitored in five wells in the Brunswick area in 1995; data from two of these wells (fig. 48) are summarized in figures 49 and 50. Water levels in wells tapping the Lower Floridan aquifer in this area are mainly influenced by withdrawal from the Upper Floridan aquifer (Krause and Randolph, 1989). The hydrographs of these wells are similar to those of the Upper Floridan aquifer in Glynn County (figs. 42-45). The 1995 mean water levels in wells 34H391 (fig. 49) and 33J044 (fig. 50) were 0.7 and $0.9 \mathrm{ft}$ higher than in 1994, respectively. Record-high daily mean water levels were recorded in wells $34 \mathrm{H} 391$ (fig. 49) and $33 \mathrm{~J} 044$ (fig. 50) that were 0.7 and $0.9 \mathrm{ft}$ higher than the previous record highs, respectively.

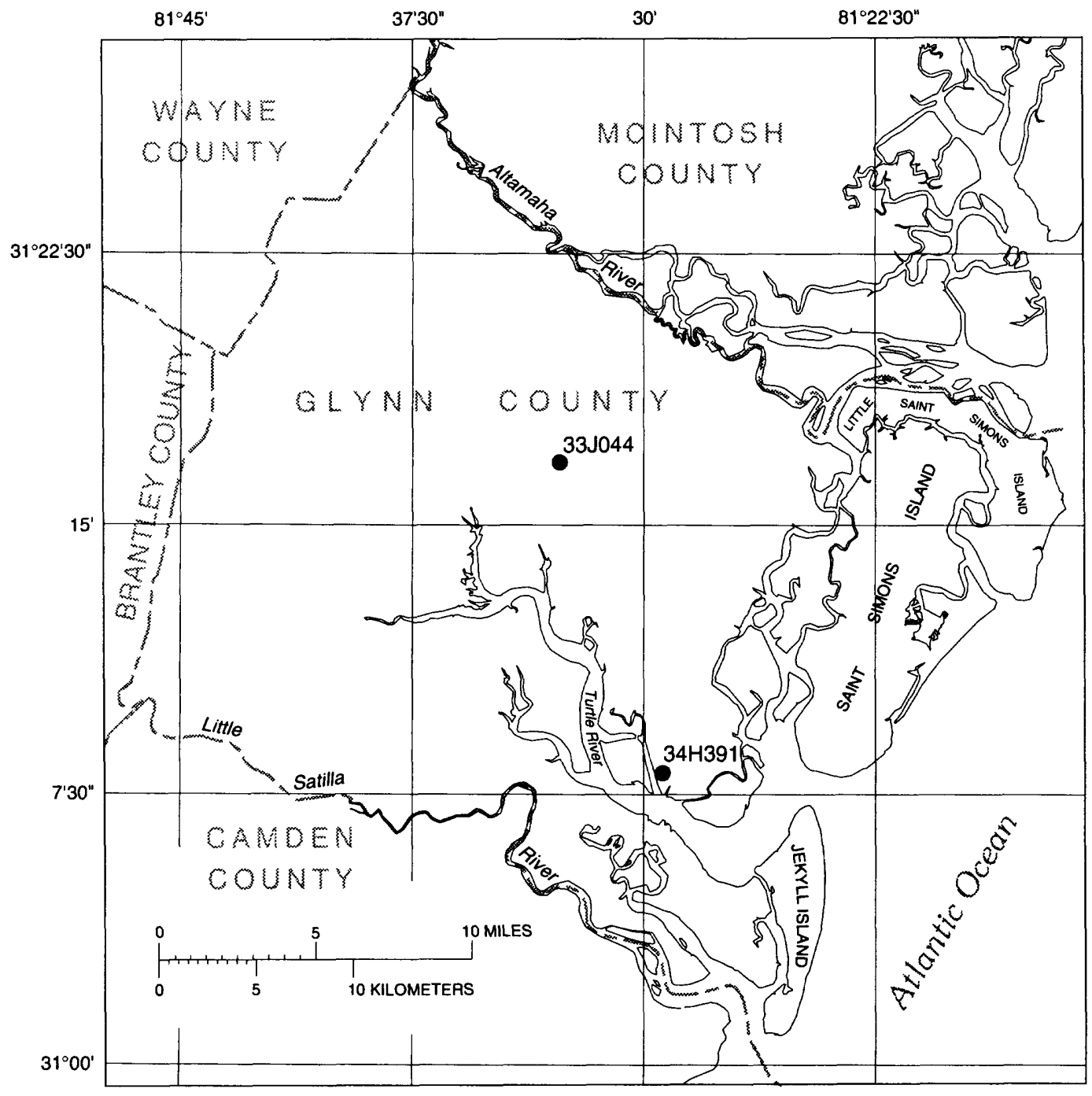

Base from U.S. Geological Survey digital data, 1:100,000, 1981 Universal Transverse Mercator projection, Zone 17

EXPLANATION

$\bullet^{34 H 391}$ OBSERVATION WELL AND IDENTIFICATION NUMBER

Figure 48.-Locations of observation wells completed in the Lower Floridan aquifer. 
310818081294201 Local number, 34H391.

LOCATION.-Lat $31^{\circ} 08^{\prime} 18^{\prime \prime}$, long $81^{\circ} 29^{\prime} 42^{\prime \prime}$, Hydrologic Unit 03070203.

SITE NAME.-U.S. Geological Survey, test well 16.

INSTRUMENTATION.-Digital recorder.

AQUIFER.-Lower Floridan.

WELL CHARACTERISTICS.-Drilled observation well, diameter 6 in., depth 1,150 ft, cased to $1,070 \mathrm{ft}$, open hole.

DATUM.-Altitude of land-surface datum is $7.13 \mathrm{ft}$.

REMARKS.-Well pumped and sampled for analysis of chloride concentration semi-annually. Water levels for period,

August 31 to November 19, are missing.

PERIOD OF RECORD.-August 1975 to current year. Continuous record since August 1975.

EXTREMES FOR PERIOD OF RECORD. - Highest water level, $12.34 \mathrm{ft}$ above land-surface datum, April 6, 1995;

lowest, $2.96 \mathrm{ft}$ below land-surface datum, July 27, 1977.
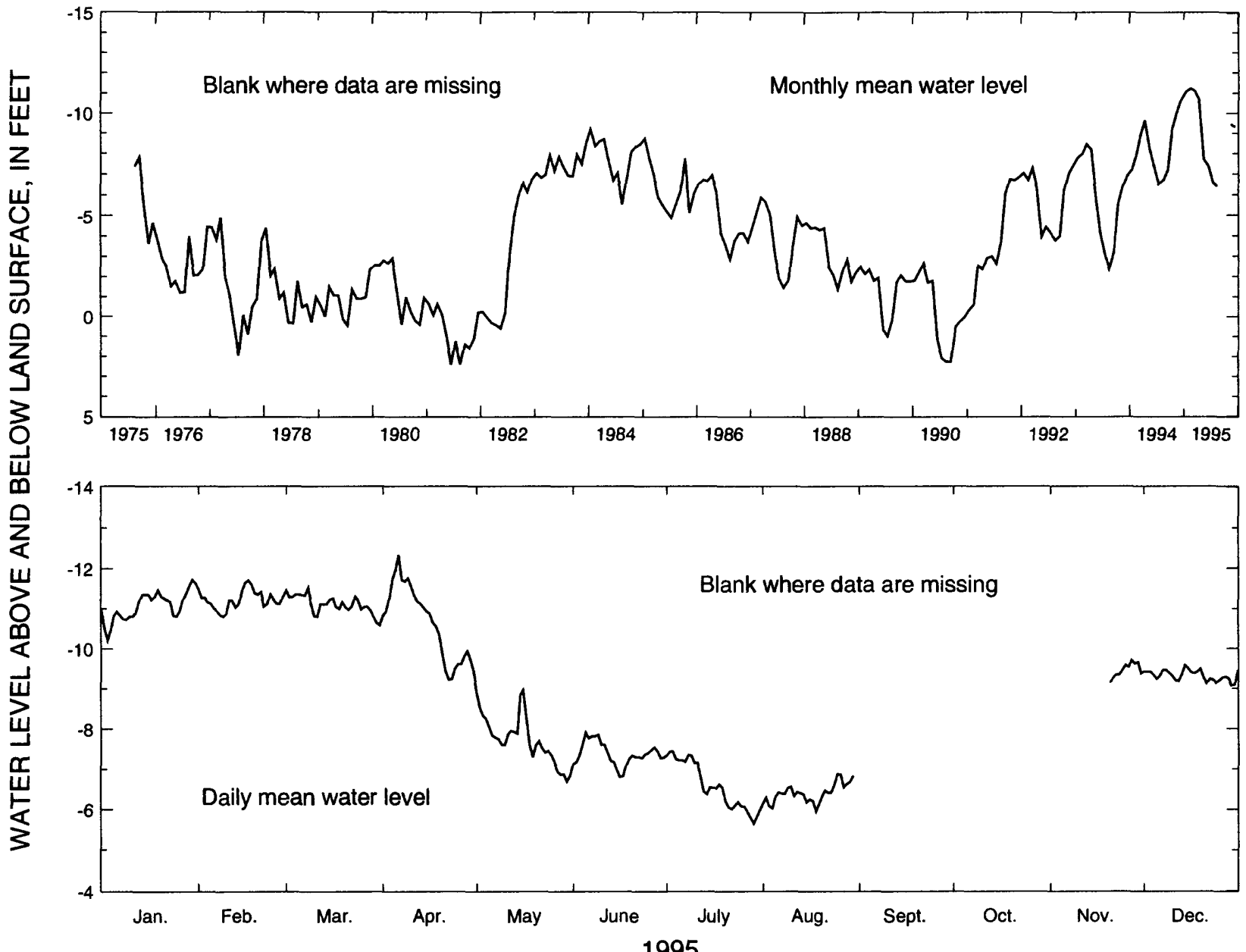

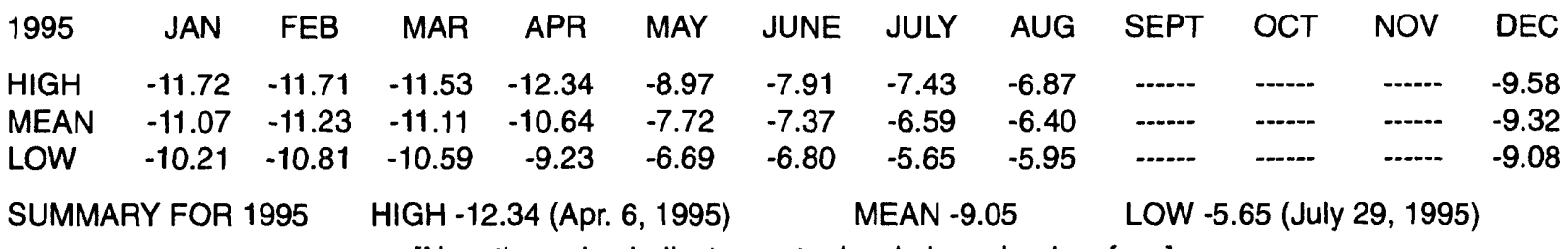

[Negative value indicates water level above land surface]

Figure 49.-Water level in observation well 34H391, Glynn County. 
311633081324001 Local number, 33J044.

LOCATION.-Lat $31^{\circ} 16^{\prime} 33^{\prime \prime}$, long $81^{\circ} 32^{\prime} 40^{\prime \prime}$, Hydrologic Unit 03070203.

SITE NAME.-Georgia Pacific Company, U.S. Geological Survey, test well 27.

INSTRUMENTATION.-Digital recorder.

AQUIFER. - Lower Floridan.

WELL CHARACTERISTICS. - Drilled unused oil-test well converted to observation well, diameter 9 in., depth 2,260

$\mathrm{ft}$, cased to $1,079 \mathrm{ft}$, open hole.

DATUM.-Altitude of land-surface datum is $20 \mathrm{ft}$.

REMARKS.-This is the Sterling oil-test well.

PERIOD OF RECORD.-May 1979 to current year. Continuous record since May 1979.

EXTREMES FOR PERIOD OF RECORD. - Highest water level, $4.56 \mathrm{ft}$ above land-surface datum, April 6, 1995;

lowest, $8.44 \mathrm{ft}$ below land-surface datum, September 19, 1990.

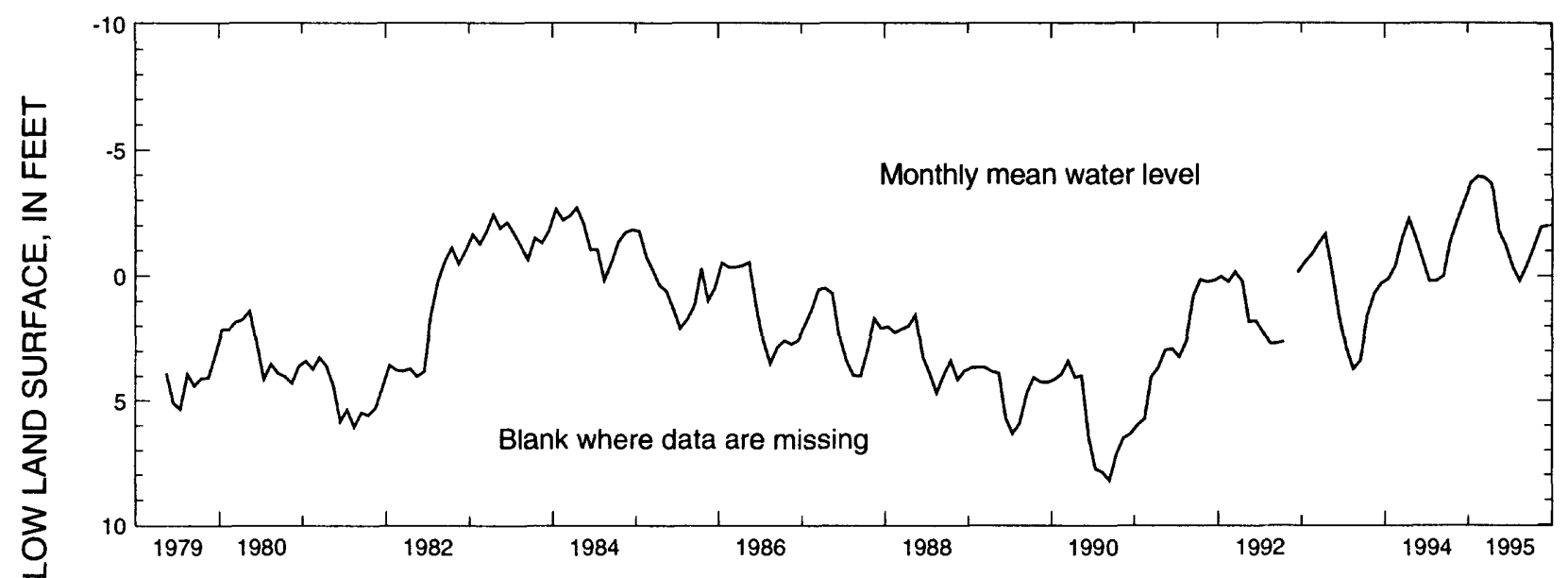

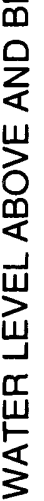

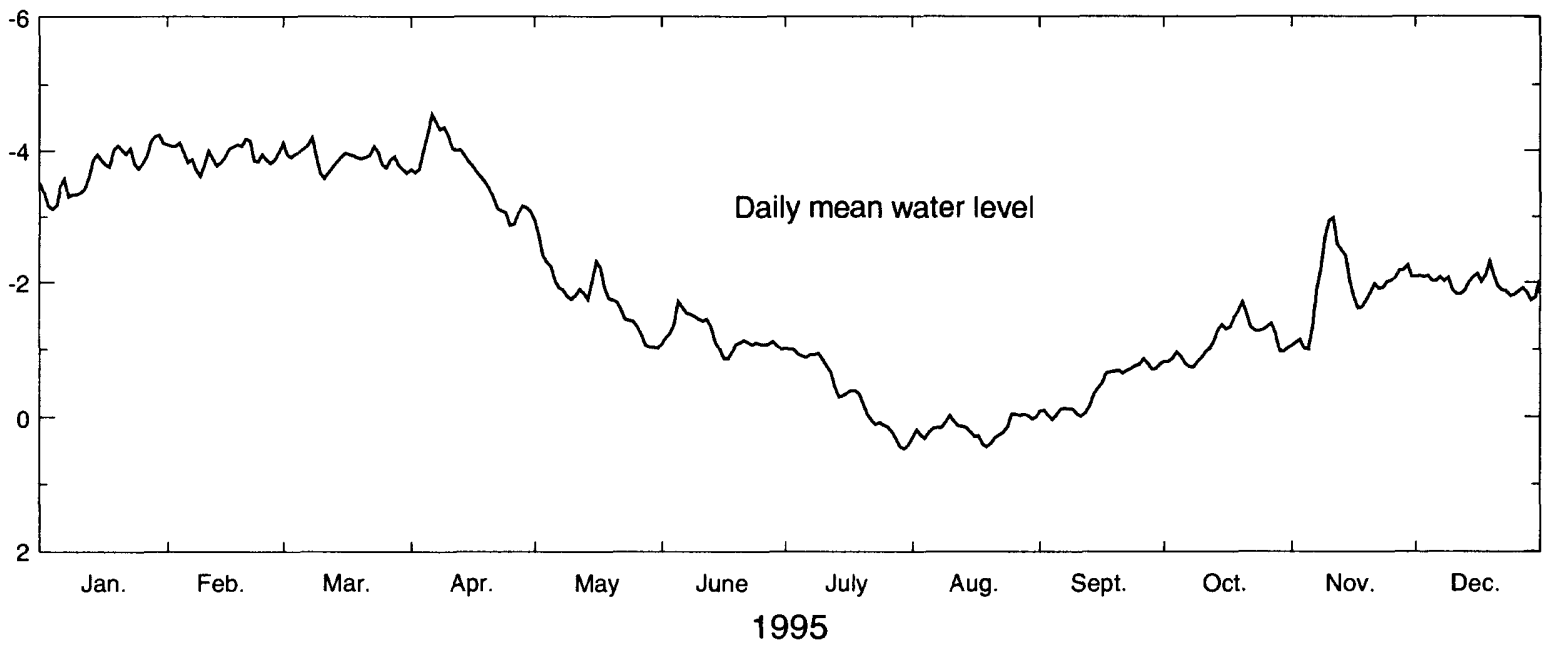

$\begin{array}{lllllllllllll}1995 & \text { JAN } & \text { FEB } & \text { MAR } & \text { APR } & \text { MAY } & \text { JUNE } & \text { JULY } & \text { AUG } & \text { SEPT } & \text { OCT } & \text { NOV } & \text { DEC } \\ \text { HIGH } & -4.24 & -4.18 & -4.20 & -4.56 & -2.95 & -1.72 & -1.01 & -0.04 & -0.86 & -1.71 & -2.98 & -2.32 \\ \text { MEAN } & -3.71 & -3.94 & -3.89 & -3.66 & -1.79 & -1.20 & -0.36 & 0.17 & -0.41 & -1.13 & -1.94 & -1.98 \\ \text { LOW } & -3.12 & -3.61 & -3.58 & -2.87 & -1.02 & -0.86 & 0.47 & 0.44 & 0.04 & -0.74 & -1.00 & -1.74\end{array}$

SUMMARY FOR 1995 HIGH -4.56 (Apr. 6, 1995) MEAN -1.97 LOW 0.47 (July 30, 1995)

[Negative value indicates water level above land surface]

Figure 50.-Water level in observation well 33J044, Glynn County. 


\section{Claiborne Aquifer}

The water level in the Claiborne aquifer was monitored in 21 wells in 1995 and data from eight of these wells (fig. 51) are summarized in figures 52-59. The water level in the aquifer is affected mainly by precipitation and by local and regional pumping (Hicks and others, 1981). The water level generally is highest following the winter and spring rainy seasons, and lowest in the fall following the summer irrigation season. Water levels in the eight wells ranged from $7.5 \mathrm{ft}$ lower to $2.1 \mathrm{ft}$ higher in 1995 than in 1994 . Record-high daily mean water levels were recorded in wells $06 \mathrm{~K} 010$ (fig. 52) and $11 \mathrm{~K} 002$ (fig. 54) that were 0.6 and $0.5 \mathrm{ft}$ higher than the previous record highs, respectively. Record-low daily mean water levels were recorded in wells 13M005 (fig. 58) and 14P015 (fig. 59 ) that were 0.5 and $6.7 \mathrm{ft}$ lower than the previous record lows, respectively.

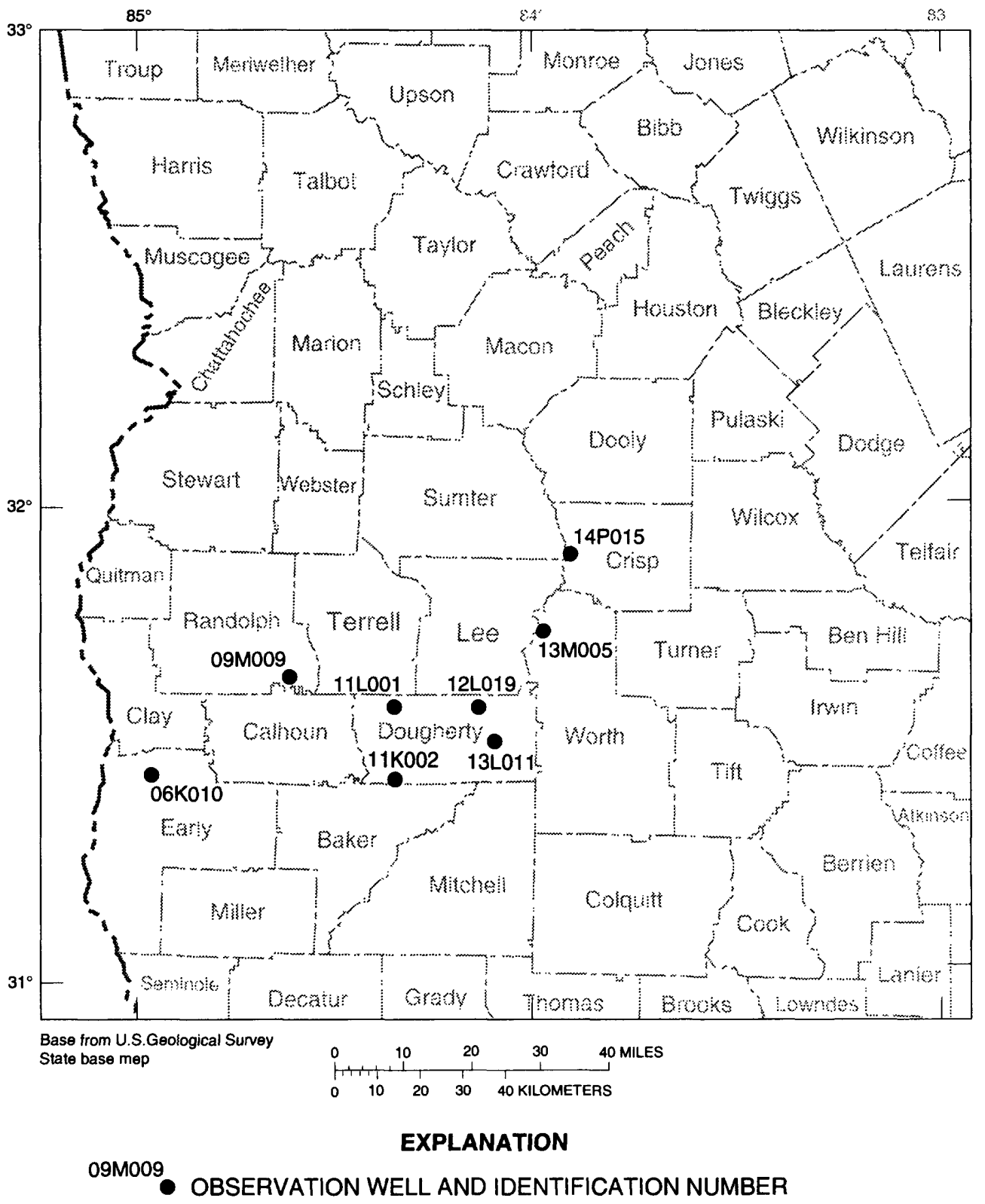

Figure 51.-Locations of observation wells completed in the Claiborne aquifer. 
312827084551503 Local number, 06 K010.

LOCATION. - Lat $31^{\circ} 28^{\prime} 24^{\prime \prime}$, long $84^{\circ} 55^{\prime} 09^{\prime \prime}$, Hydrologic Unit 03130004.

SITE NAME.-Georgia Geologic Survey, Kolomoki Mounds State Park, test well 3.

INSTRUMENTATION.-Digital recorder.

AQUIFER.-Claiborne.

WELL CHARACTERISTICS.-Drilled observation well, diameter $4 \mathrm{in}$., depth $140 \mathrm{ft}$, cased to $120 \mathrm{ft}$, screen to $140 \mathrm{ft}$. DATUM.-Altitude of land-surface datum is $310 \mathrm{ft}$.

REMARKS.-None.

PERIOD OF RECORD.-August 1984 to current year. Continuous record since January 1985.

EXTREMES FOR PERIOD OF RECORD. - Highest water level, $72.22 \mathrm{ft}$ below land-surface datum, March 18, 1995; lowest, $77.35 \mathrm{ft}$ below land-surface datum, November 14, 1986.
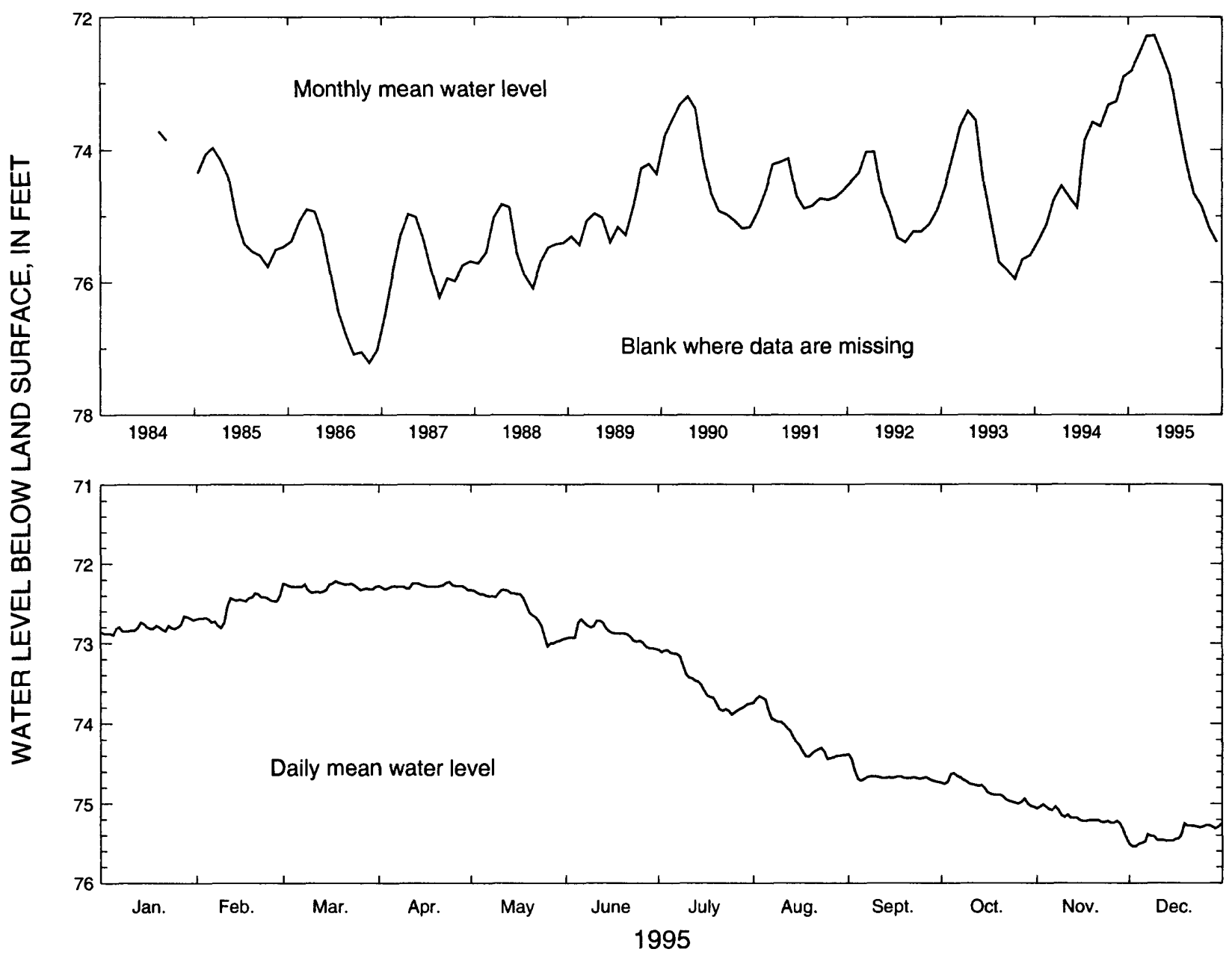

\begin{tabular}{lcccccccccccc} 
1995 & JAN & FEB & MAR & APR & MAY & JUNE & JULY & AUG & SEPT & OCT & NOV & DEC \\
HIGH & 72.66 & 72.37 & 72.22 & 72.23 & 72.33 & 72.70 & 73.08 & 73.66 & 74.38 & 74.62 & 75.01 & 75.25 \\
MEAN & 72.81 & 72.54 & 72.29 & 72.28 & 72.57 & 72.88 & 73.53 & 74.15 & 74.66 & 74.84 & 75.18 & 75.39 \\
LOW & 72.90 & 72.81 & 72.36 & 72.33 & 73.04 & 73.07 & 73.89 & 74.44 & 74.73 & 75.04 & 75.44 & 75.54 \\
\multicolumn{3}{l}{ SUMMARY FOR 1995 } & \multicolumn{3}{l}{ HIGH 72.22 (Mar. 18, 1995) } & \multicolumn{3}{l}{ MEAN 73.60 } & LOW 75.54 (Dec. 2-3, 1995)
\end{tabular}

Figure 52.-Water level in observation well 06K010, Early County. 
313953084361201 Local number, 09 M009.

LOCATION.-Lat $31^{\circ} 39^{\prime} 52^{\prime \prime}$, long $84^{\circ} 36^{\prime} 10^{\prime \prime}$, Hydrologic Unit 03130009.

SITE NAME.-C.T. Martin, test well 1.

INSTRUMENTATION.-Digital recorder.

AQUIFER.-Claiborne.

WELL CHARACTERISTICS.-Drilled observation well, diameter $4 \mathrm{in}$., depth $94 \mathrm{ft}$, cased to $77 \mathrm{ft}$, screen to $94 \mathrm{ft}$.

DATUM.-Altitude of land-surface datum is $322 \mathrm{ft}$.

REMARKS. - None.

PERIOD OF RECORD. - September 1984 to current year. Continuous record since September 1984.

EXTREMES FOR PERIOD OF RECORD.-Highest water level, $24.30 \mathrm{ft}$ below land-surface datum, April 1, 1993;

lowest, $30.50 \mathrm{ft}$ below land-surface datum, November 3, 1986.
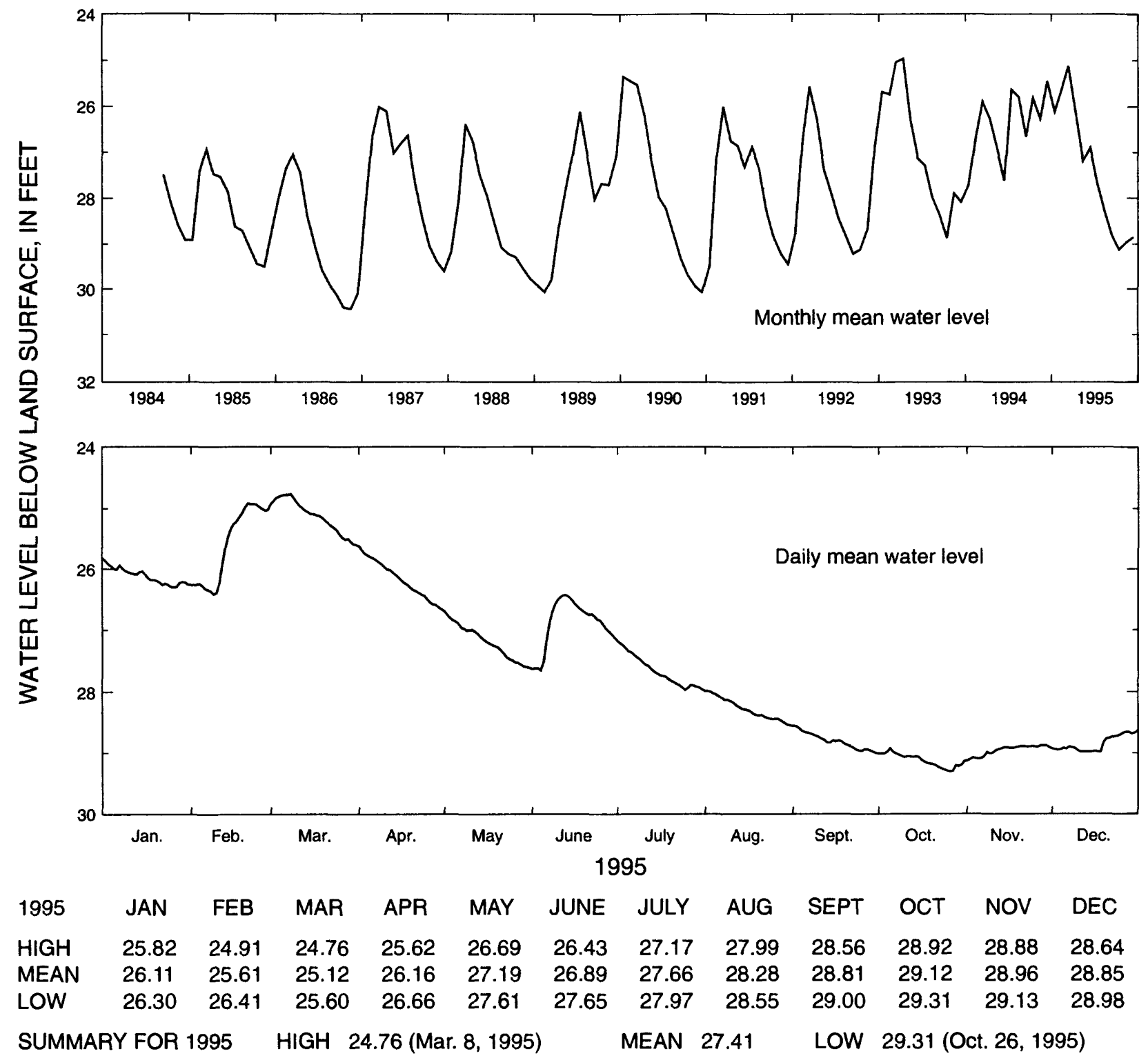

Figure 53.-Water level in observation well 09M009, Randolph County. 
312654084210102 Local number, $11 \mathrm{~K} 002$.

LOCATION.-Lat $31^{\circ} 26^{\prime} 54^{\prime \prime}$, long 84 ${ }^{\circ} 21^{\prime} 01^{\prime \prime}$, Hydrologic Unit 03130008.

SITE NAME.-U.S. Geological Survey, test well 11.

INSTRUMENTATION.-Digital recorder.

AQUIFER.-Claiborne.

WELL CHARACTERISTICS. -Drilled observation well, diameter 4 in., depth $320 \mathrm{ft}$, cased to $300 \mathrm{ft}$, screen to $320 \mathrm{ft}$. DATUM.-Altitude of land-surface datum is $183.5 \mathrm{ft}$.

REMARKS.-None.

PERIOD OF RECORD.-May 1979 to current year. Continuous record since May 1979.

EXTREMES FOR PERIOD OF RECORD. - Highest water level, $21.57 \mathrm{ft}$ below land-surface datum, June 6, 1995; lowest, $28.04 \mathrm{ft}$ below land-surface datum, December 24, 1981.

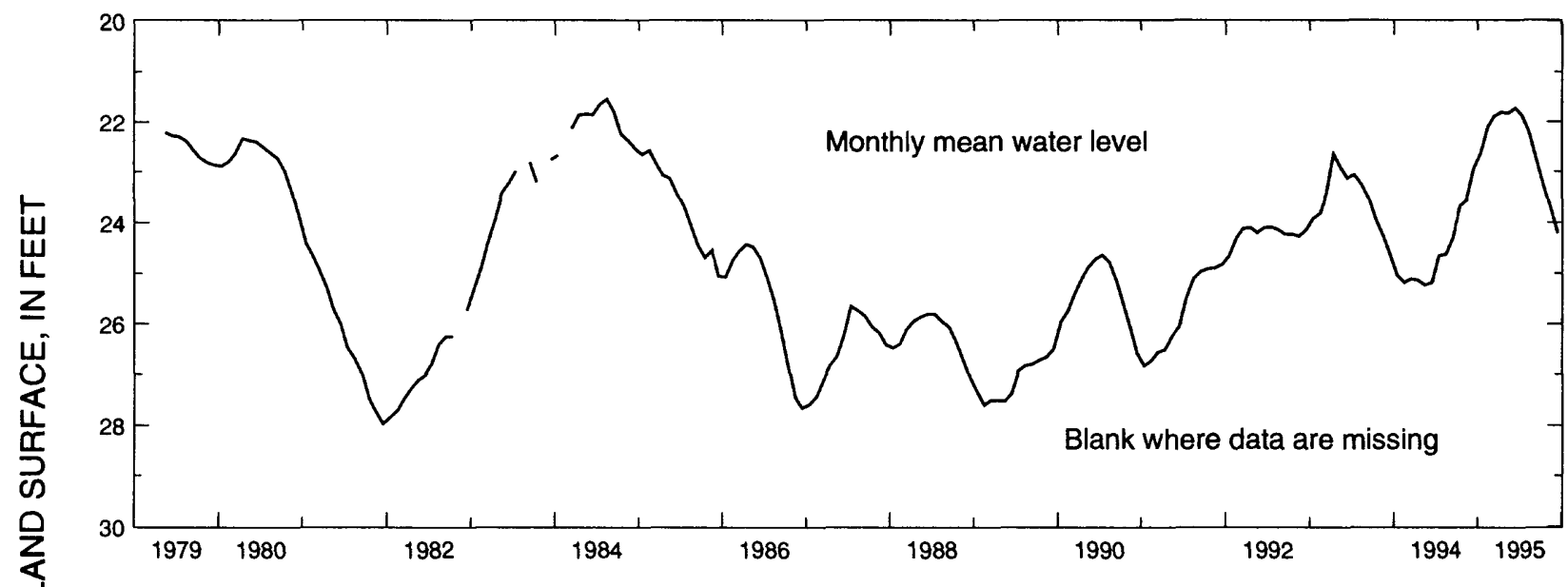

蛋

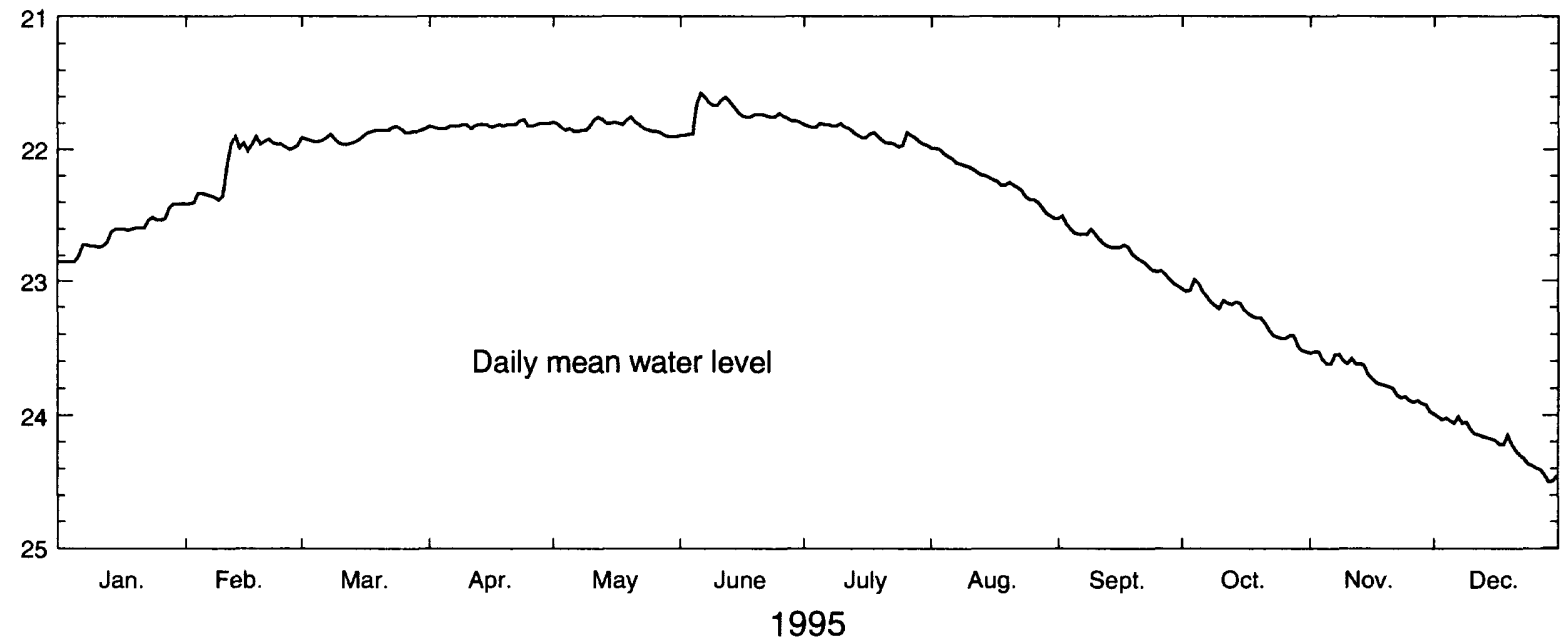

\begin{tabular}{lcccccccccccc}
1995 & JAN & FEB & MAR & APR & MAY & JUNE & JULY & AUG & SEPT & OCT & NOV & DEC \\
HIGH & 22.41 & 21.90 & 21.82 & 21.77 & 21.75 & 21.57 & 21.80 & 21.99 & 22.50 & 22.99 & 23.53 & 23.99 \\
MEAN & 22.64 & 22.11 & 21.89 & 21.81 & 21.83 & 21.73 & 21.88 & 22.23 & 22.76 & 23.25 & 23.72 & 24.21 \\
LOW & 22.85 & 22.41 & 21.96 & 21.84 & 21.90 & 21.89 & 21.98 & 22.52 & 23.04 & 23.53 & 23.97 & 24.50 \\
\multicolumn{3}{l}{ SUMMARY FOR 1995 } & HIGH & 21.57 (June 6, 1995) & MEAN & 22.51 & LOW & 24.50 (Dec. 29, 1995)
\end{tabular}

Figure 54.-Water level in observation well 11K002, Dougherty County. 
313530084203202 Local number, 11 L001.

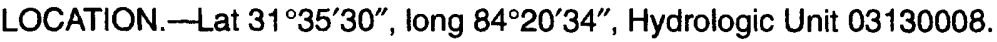

SITE NAME.-U.S. Geological Survey, test well 4.

INSTRUMENTATION.-Digital recorder.

AQUIFER.-Claiborne.

WELL CHARACTERISTICS. -Drilled observation well, diameter 4 in., depth $251 \mathrm{ft}$, cased to $233 \mathrm{ft}$, screen to $251 \mathrm{ft}$. DATUM.-Altitude of land-surface datum is $220 \mathrm{ft}$.

REMARKS.-None.

PERIOD OF RECORD. - March 1978 to current year. Continuous record since March 1978.

EXTREMES FOR PERIOD OF RECORD.-Highest water level, $12.11 \mathrm{ft}$ below land-surface datum, June 5-6, 1978;

lowest, $34.75 \mathrm{ft}$ below land-surface datum, October 19-20, 1986.

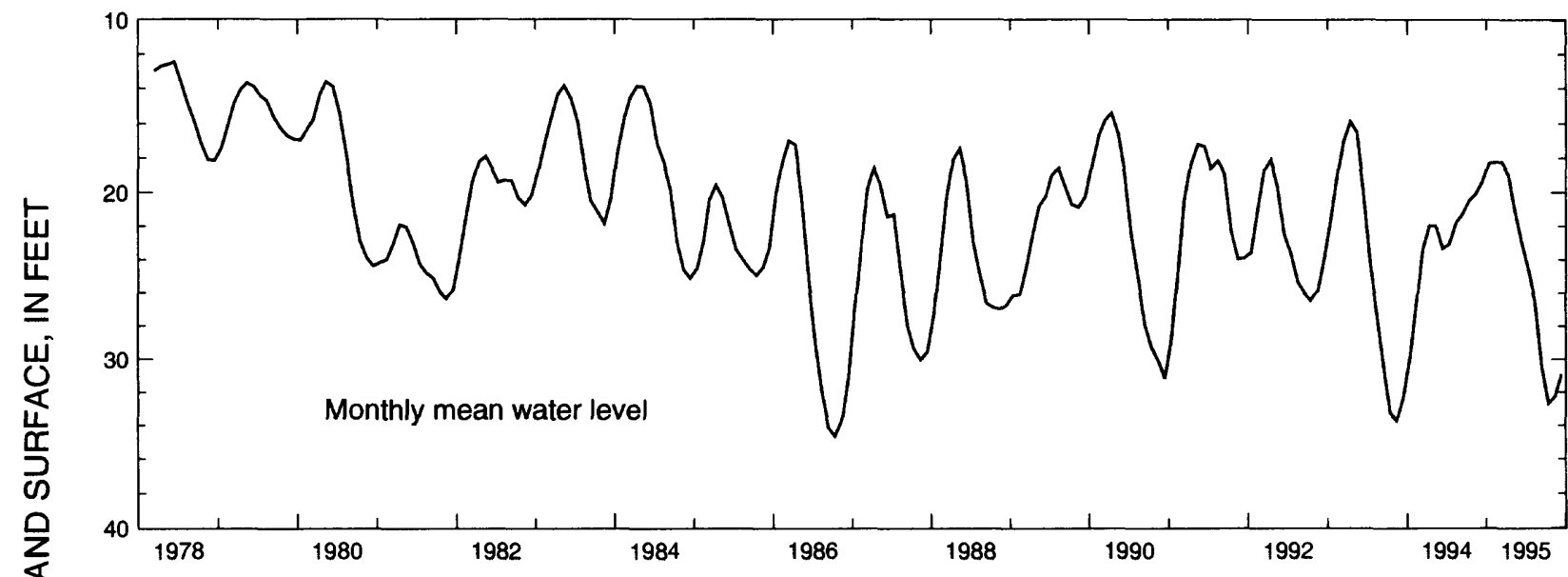

\begin{tabular}{lcccccccccccc}
1995 & JAN & FEB & MAR & APR & MAY & JUNE & JULY & AUG & SEPT & OCT & NOV & DEC \\
HIGH & 17.95 & 18.10 & 18.00 & 18.47 & 19.70 & 22.57 & 23.83 & 25.86 & 28.02 & 31.95 & 31.36 & 30.19 \\
MEAN & 18.29 & 18.25 & 18.23 & 18.99 & 21.16 & 23.02 & 24.62 & 26.56 & 30.45 & 32.68 & 32.24 & 30.92 \\
LOW & 18.65 & 18.49 & 18.44 & 19.67 & 22.54 & 23.77 & 25.80 & 27.89 & 31.90 & 32.98 & 32.75 & 31.36 \\
\multicolumn{3}{l}{ SUMMARY FOR 1995 } & HIGH & 17.95 (Jan. 14, 1995) & MEAN & 24.65 & LOW & 32.98 (Oct. 24-25, 1995)
\end{tabular}

Figure 55.-Water level in observation well 11L001, Dougherty County. 
313534084103001 Local number, 12 L019.

LOCATION. - Lat $31^{\circ} 35^{\prime} 36^{\prime \prime}$, long $84^{\circ} 10^{\prime} 30^{\prime \prime}$, Hydrologic Unit 03130008.

SITE NAME.-U.S. Geological Survey, test well 5.

INSTRUMENTATION.-Electronic data recorder.

AQUIFER.-Claiborne.

WELL CHARACTERISTICS. - Drilled observation well, diameter $4 \mathrm{in}$., depth $257 \mathrm{ft}$, cased to $241 \mathrm{ft}$, screen to $257 \mathrm{ft}$.

DATUM.-Altitude of land-surface datum is $198 \mathrm{ft}$.

REMARKS.-None.

PERIOD OF RECORD.--March 1978 to current year. Continuous record since March 1978.

EXTREMES FOR PERIOD OF RECORD.-Highest water level, $57.31 \mathrm{ft}$ below land-surface datum, April 7, 1992;

lowest, $99.53 \mathrm{ft}$ below land-surface datum, August 1-2, 1978.
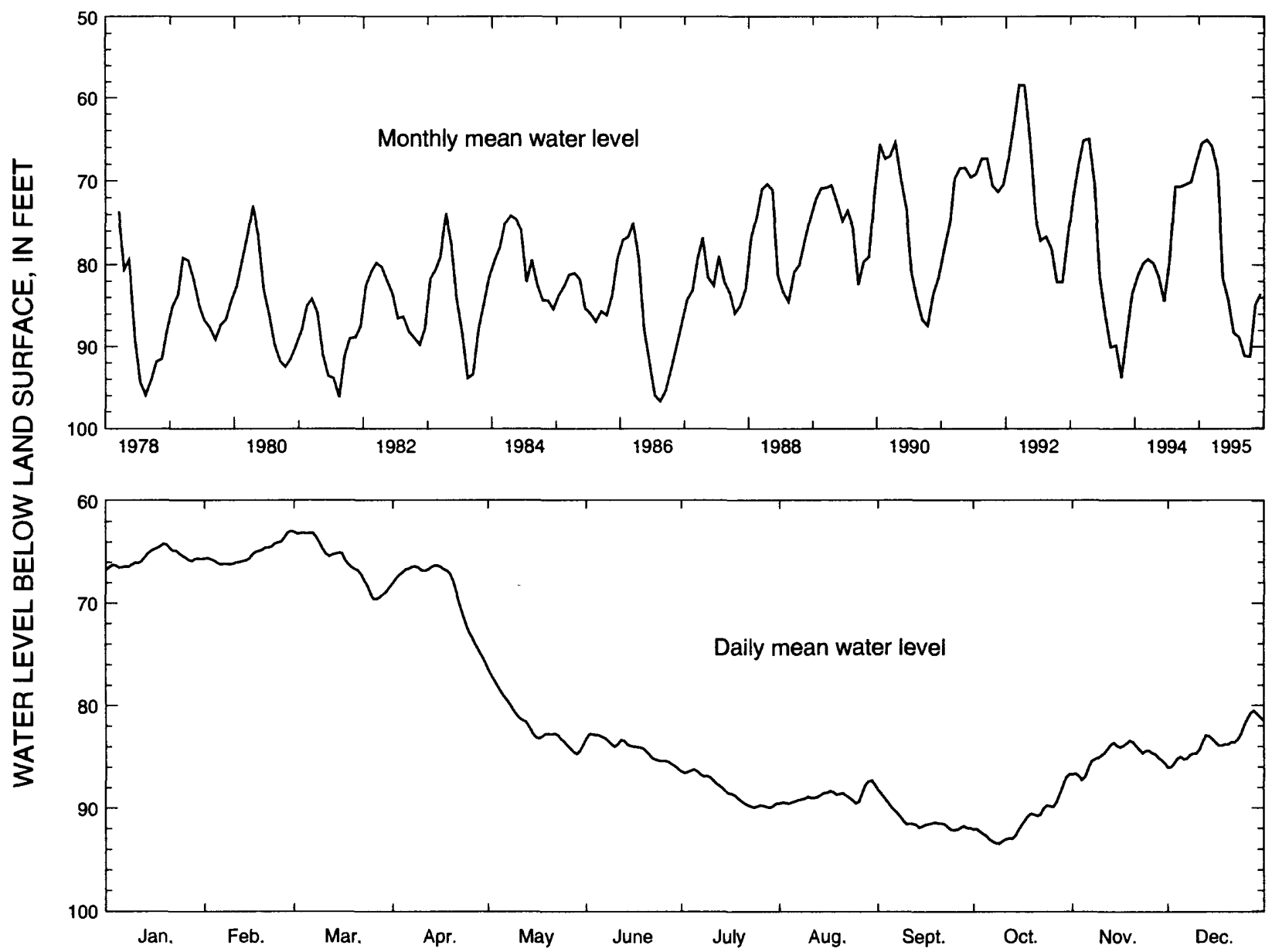

1995

$\begin{array}{lllllllllllll}1995 & \text { JAN } & \text { FEB } & \text { MAR } & \text { APR } & \text { MAY } & \text { JUNE } & \text { JULY } & \text { AUG } & \text { SEPT } & \text { OCT } & \text { NOV } & \text { DEC } \\ \text { HIGH } & 64.18 & 62.96 & 63.01 & 66.30 & 76.38 & 82.77 & 86.22 & 87.30 & 88.17 & 86.70 & 83.41 & 80.51 \\ \text { MEAN } & 65.56 & 65.14 & 65.94 & 68.78 & 81.66 & 84.18 & 88.28 & 88.81 & 91.14 & 91.22 & 84.90 & 83.52 \\ \text { LOW } & 66.68 & 66.20 & 69.59 & 75.70 & 84.67 & 86.19 & 89.95 & 89.55 & 92.16 & 93.46 & 87.25 & 86.04\end{array}$

SUMMARY FOR 1995 HIGH 62.96 (Feb. 28, 1995) MEAN 80.02 LOW 93.46 (Oct. 9, 1995)

Figure 56.-Water level in observation well 12L019, Dougherty County. 
313105084064301 Local number, 13L011.

LOCATION.-Lat $31^{\circ} 31^{\prime} 05^{\prime \prime}$, long $84^{\circ} 06^{\prime} 43^{\prime \prime}$, Hydrologic Unit 03130008.

SITE NAME.-U.S. Geological Survey, test well 2.

INSTRUMENTATION.-Electronic data recorder.

AQUIFER.-Claiborne.

WELL CHARACTERISTICS. -Drilled observation well, diameter $4 \mathrm{in}$., depth $418 \mathrm{ft}$, cased to $398 \mathrm{ft}$, screen to $418 \mathrm{ft}$.

DATUM.-Altitude of land-surface datum is $195 \mathrm{ft}$.

REMARKS.-None.

PERIOD OF RECORD. June 1977 to current year. Continuous record since June 1977.

EXTREMES FOR PERIOD OF RECORD.-Highest water level, $60.01 \mathrm{ft}$ below land-surface datum, April 5, 1978;

lowest, $95.00 \mathrm{ft}$ below land-surface datum, August 9-11, 1981.

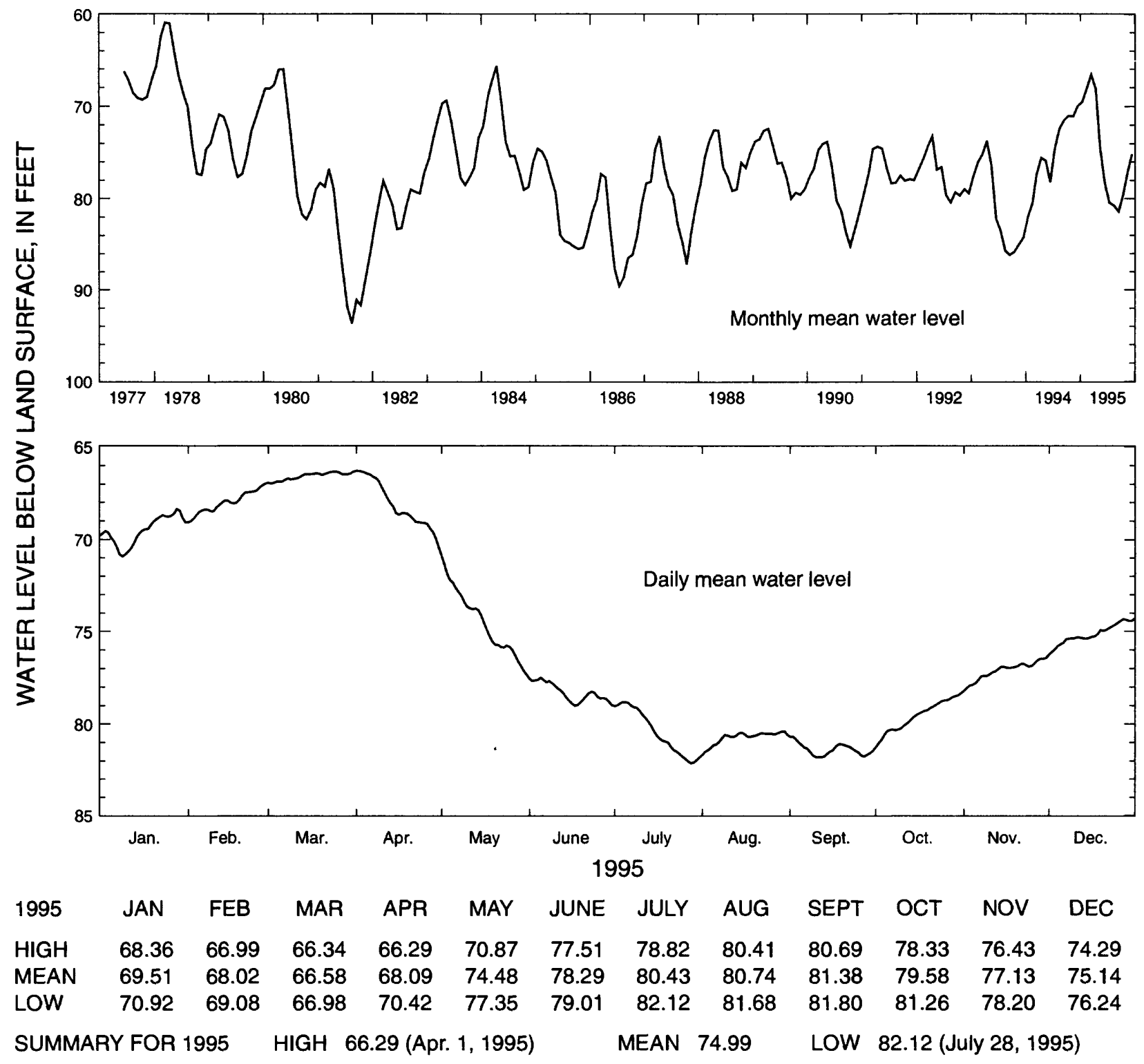

Figure 57.-Water level in observation well 13L011, Dougherty County. 
314330084005401 Local number, $13 \mathrm{M} 005$.

LOCATION.-Lat $31^{\circ} 43^{\prime} 30^{\prime \prime}$, long $84^{\circ} 00^{\prime} 54^{\prime \prime}$, Hydrologic Unit 03130006.

SITE NAME.-U.S. Geological Survey, test well DP-7.

INSTRUMENTATION.-Digital recorder.

AQUIFER.-Claiborne.

WELL CHARACTERISTICS.-Drilled observation well, diameter 6 in., depth $345 \mathrm{ft}$, cased to $330 \mathrm{ft}$, screen to $345 \mathrm{ft}$.

DATUM.-Altitude of land-surface datum is $230 \mathrm{ft}$.

REMARKS.-None.

PERIOD OF RECORD.-April 1980 to current year. Continuous record since April 1980.

EXTREMES FOR PERIOD OF RECORD. - Highest water level, $2.89 \mathrm{ft}$ below land-surface datum, May 29, 1980;

lowest, $23.90 \mathrm{ft}$ below land-surface datum, August 19, 1995.

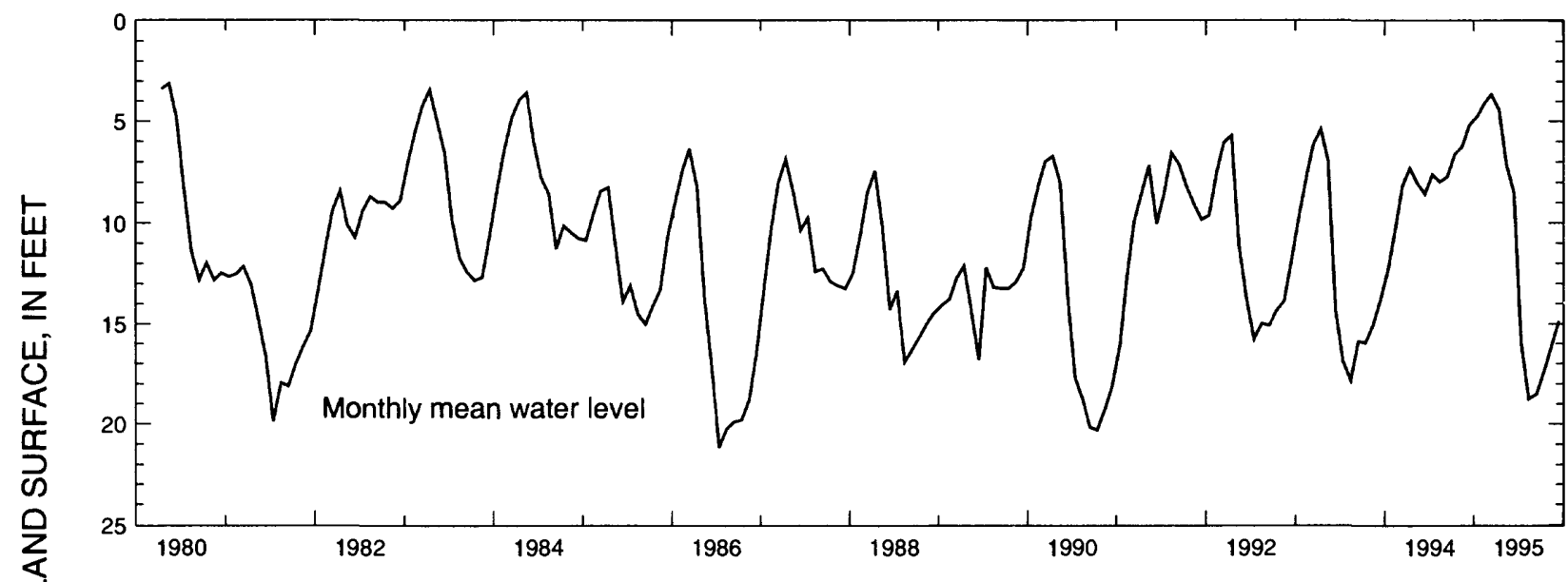

虫

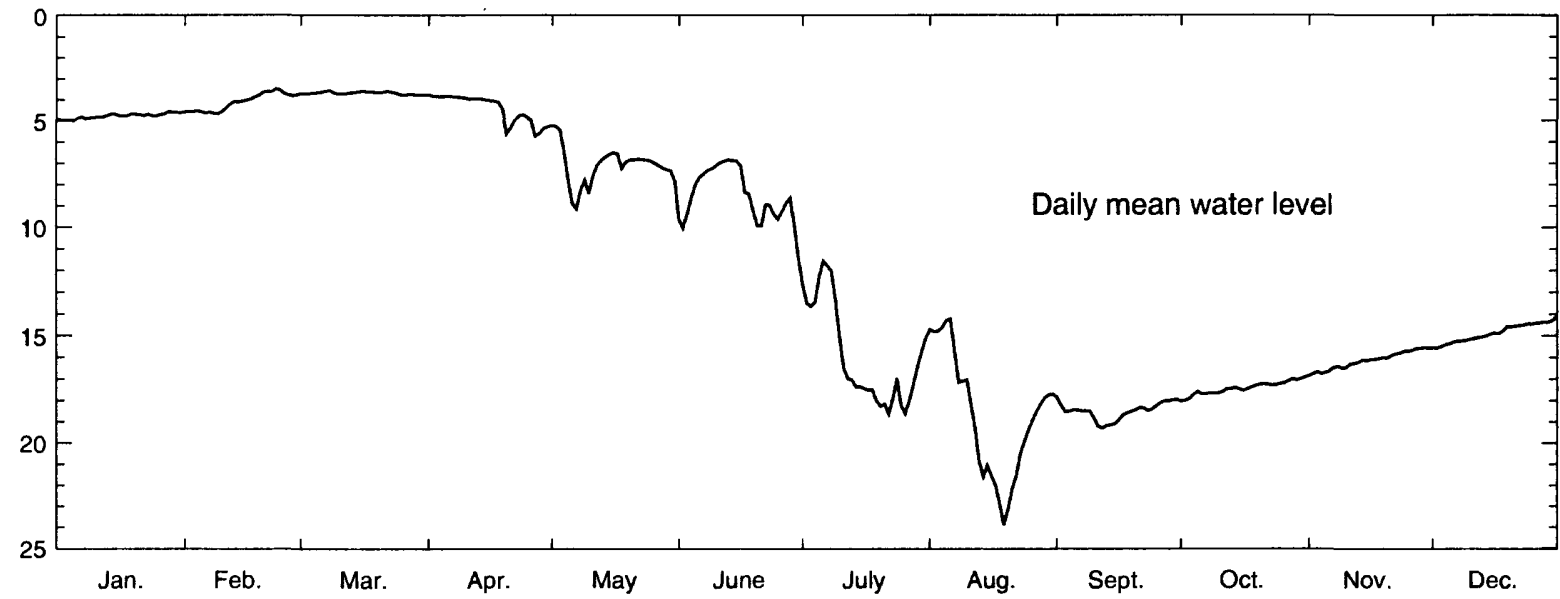

1995

$\begin{array}{lllllllllllll}1995 & \text { JAN } & \text { FEB } & \text { MAR } & \text { APR } & \text { MAY } & \text { JUNE } & \text { JULY } & \text { AUG } & \text { SEPT } & \text { OCT } & \text { NOV } & \text { DEC } \\ \text { HIGH } & 4.57 & 3.47 & 3.53 & 3.75 & 5.23 & 6.83 & 11.54 & 14.22 & 17.85 & 16.90 & 15.53 & 14.12 \\ \text { MEAN } & 4.78 & 4.11 & 3.66 & 4.40 & 7.08 & 8.50 & 15.94 & 18.74 & 18.50 & 17.42 & 16.14 & 14.86 \\ \text { LOW } & 5.00 & 4.67 & 3.77 & 5.73 & 9.13 & 11.43 & 18.62 & 23.90 & 19.29 & 18.01 & 16.83 & 15.55\end{array}$

SUMMARY FOR 1995 HIGH 3.47 (Feb. 23, 1995) MEAN $11.23 \quad$ LOW 23.90 (Aug. 19, 1995)

Figure 58.-Water level in observation well 13M005, Worth County. 
315731083542302 Local number, $14 \mathrm{P} 015$.

LOCATION. - Lat $31^{\circ} 57^{\prime} 31^{\prime \prime}$, long $83^{\circ} 54^{\prime} 23^{\prime \prime}$, Hydrologic Unit 03130006.

SITE NAME.-Georgia Geologic Survey, Veterans Memorial State Park, test well 2.

INSTRUMENTATION.-Digital recorder.

AQUIFER.-Claiborne.

WELL CHARACTERISTICS. - Drilled observation well, diameter 6 in., depth $340 \mathrm{ft}$, cased to $240 \mathrm{ft}$, screen to $340 \mathrm{ft}$. DATUM.-Altitude of land-surface datum is $252 \mathrm{ft}$.

REMARKS.-None.

PERIOD OF RECORD.-August 1984 to current year. Continuous record since August 1984.

EXTREMES FOR PERIOD OF RECORD. - Highest water level, $11.13 \mathrm{ft}$ below land-surface datum, July 10, 1994; lowest, $48.82 \mathrm{ft}$ below land-surface datum, September 18, 1995.
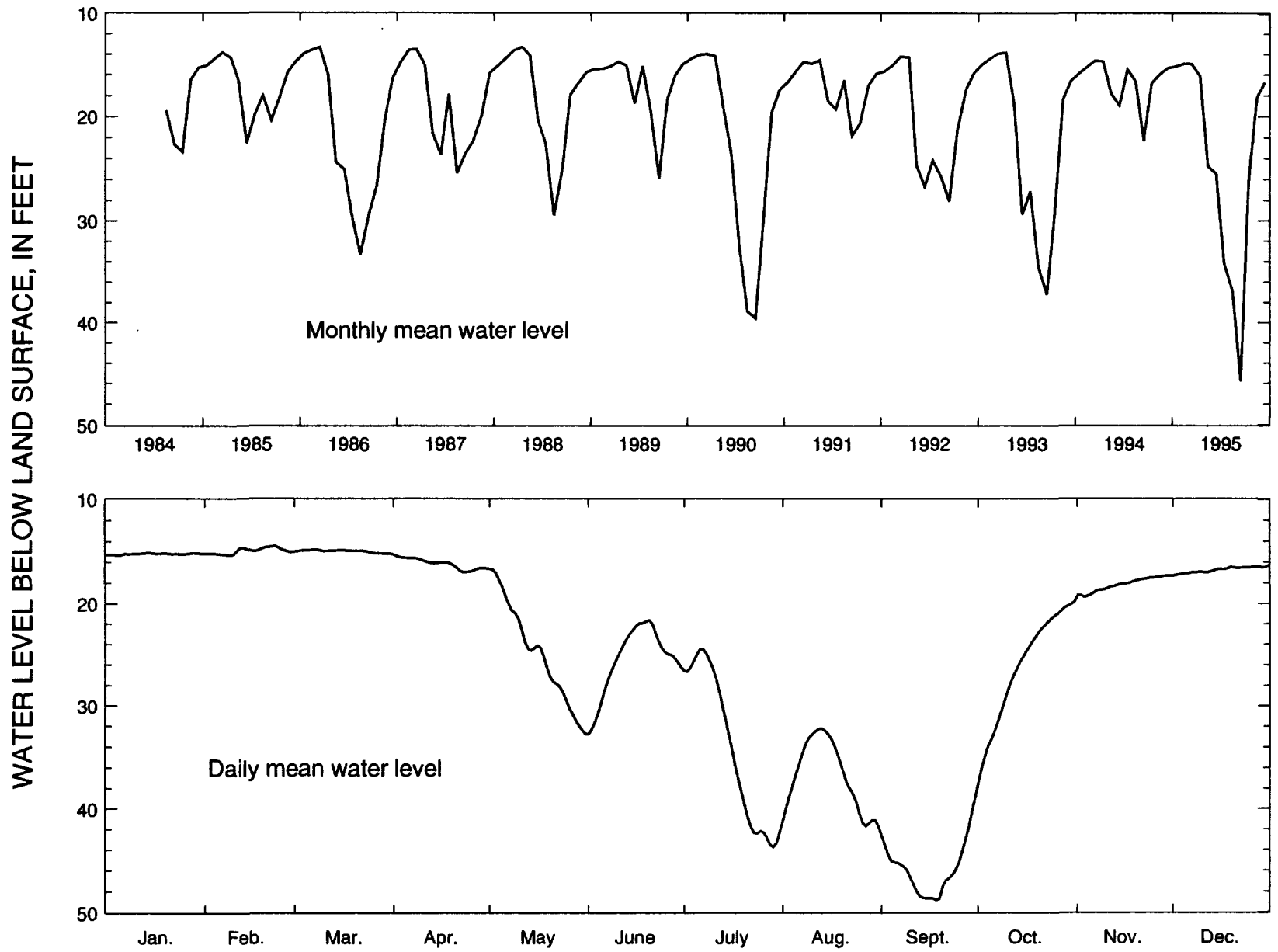

1995

$\begin{array}{lllllllllllll}1995 & \text { JAN } & \text { FEB } & \text { MAR } & \text { APR } & \text { MAY } & \text { JUNE } & \text { JULY } & \text { AUG } & \text { SEPT } & \text { OCT } & \text { NOV } & \text { DEC } \\ \text { HIGH } & 15.08 & 14.44 & 14.78 & 15.25 & 16.62 & 21.62 & 24.47 & 32.20 & 39.01 & 19.81 & 17.29 & 16.27 \\ \text { MEAN } & 15.18 & 14.91 & 14.94 & 16.11 & 24.74 & 25.43 & 34.14 & 36.85 & 45.79 & 26.16 & 18.15 & 16.73 \\ \text { LOW } & 15.34 & 15.33 & 15.18 & 16.96 & 32.72 & 32.76 & 43.75 & 41.78 & 48.82 & 37.57 & 19.35 & 17.29\end{array}$

SUMMARY FOR 1995 HIGH 14.44 (Feb. 23, 1995) MEAN 24.15 LOW 48.82 (Sept. 18, 1995)

Figure 59.-Water level in observation well 14P015, Crisp County. 


\section{Clayton Aquifer}

The water level in the Clayton aquifer was monitored in 12 wells in 1995 and data from seven of these wells (fig. 60) are summarized in figures 61-67. Water levels in wells tapping the aquifer are affected by seasonal variations in local and regional pumping (Hicks and others, 1981).

Annual mean water levels in the seven wells monitored for this report (figs. 61-67) ranged from $7.8 \mathrm{ft}$ lower to $3.2 \mathrm{ft}$ higher in 1995 than in 1994. A record-low daily mean water level was recorded in well $06 \mathrm{~K} 009$ (fig. 61) that was $0.6 \mathrm{ft}$ lower than the previous record low.

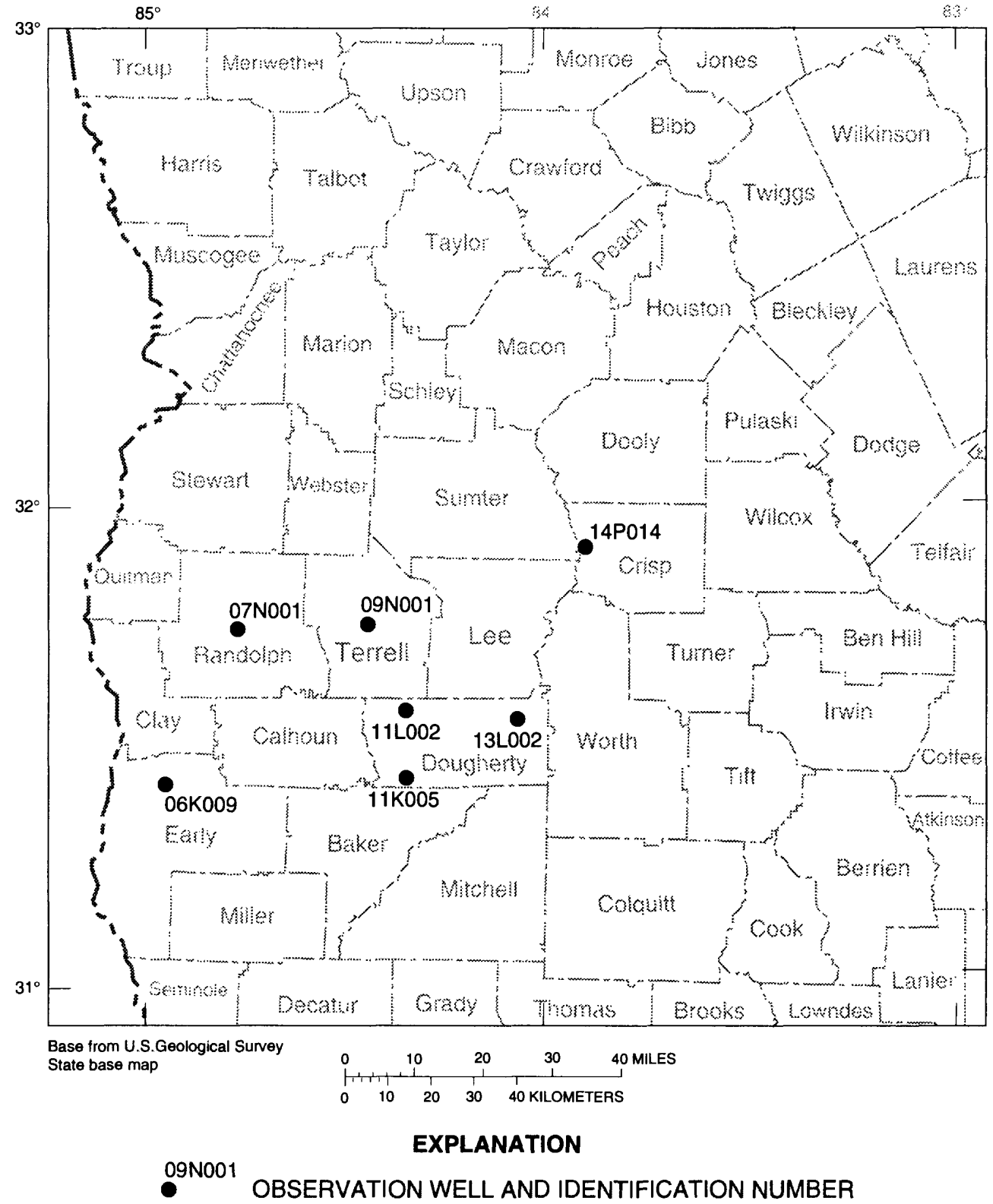

Figure 60.-Locations of observation wells completed in the Clayton aquifer. 
312827084551501 Local number, 06K009.

LOCATION.-Lat $31^{\circ} 28^{\prime} 24^{\prime \prime}$, long $84^{\circ} 55^{\prime} 12^{\prime \prime}$, Hydrologic Unit 03130004.

SITE NAME.-Georgia Geologic Survey, Kolomoki Mounds State Park, test well 1.

INSTRUMENTATION.-Digital recorder.

AQUIFER.-Clayton.

WELL CHARACTERISTICS.-Drilled observation well, diameter 6 in., depth $612 \mathrm{ft}$, cased to $491 \mathrm{ft}$, open hole.

DATUM.-Altitude of land-surface datum is $310 \mathrm{ft}$.

REMARK.-None.

PERIOD OF RECORD.--August 1984 to current year. Continuous record since August 1984.

EXTREMES FOR PERIOD OF RECORD. - Highest water level, $146.62 \mathrm{ft}$ below land-surface datum, April 3, 1986;

lowest, $175.33 \mathrm{ft}$ below land-surface datum, August 29, 1995.

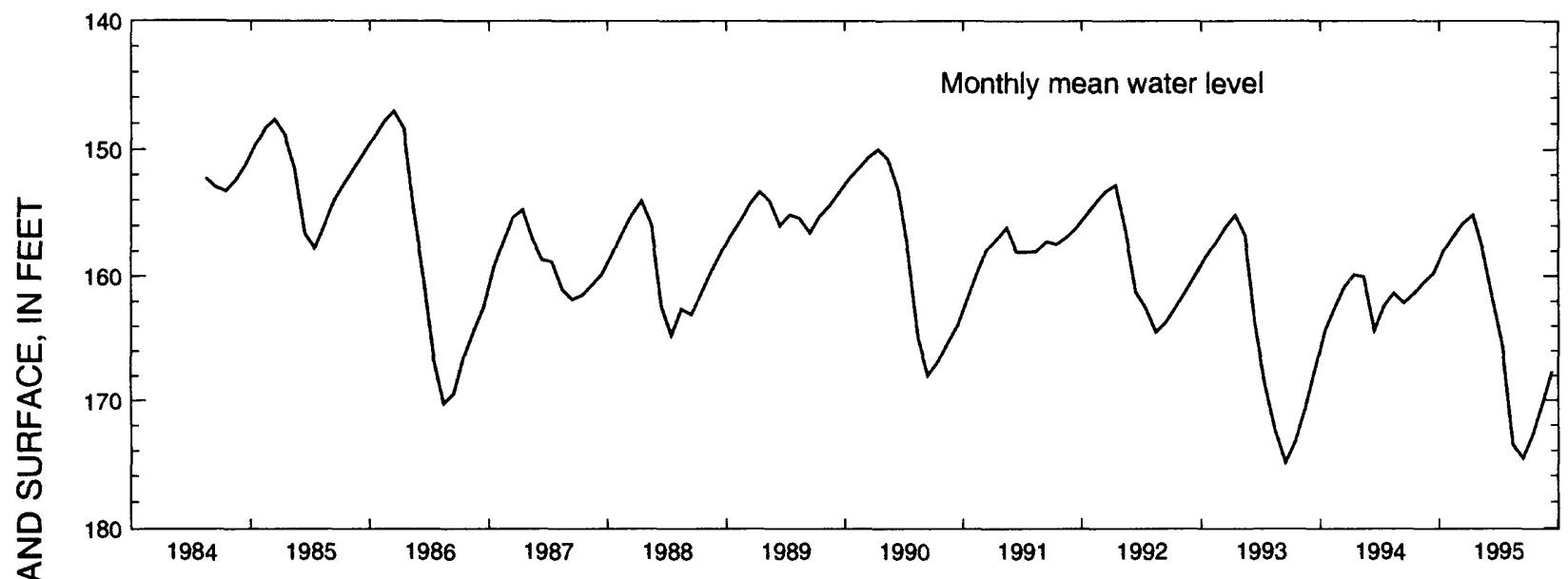

薯

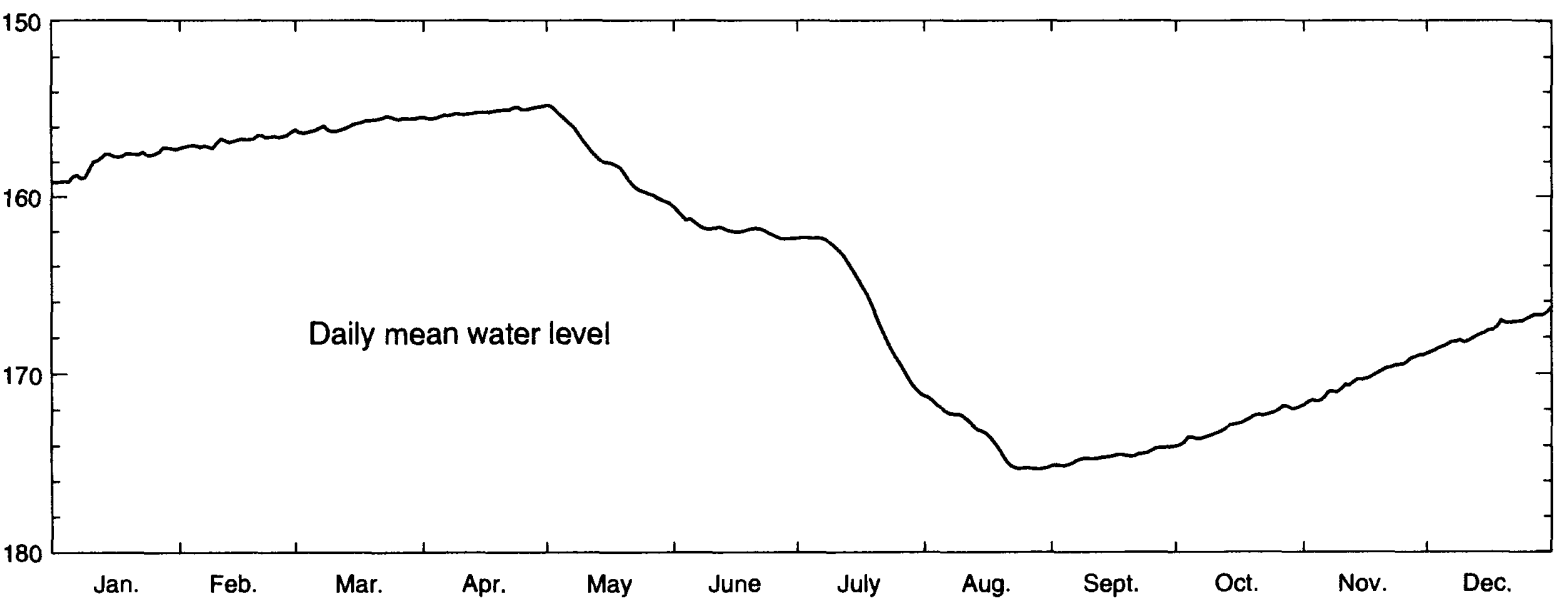

1995

$\begin{array}{lcccccccccccc}1995 & \text { JAN } & \text { FEB } & \text { MAR } & \text { APR } & \text { MAY } & \text { JUNE } & \text { JULY } & \text { AUG } & \text { SEPT } & \text { OCT } & \text { NOV } & \text { DEC } \\ \text { HIGH } & 157.17 & 156.30 & 155.39 & 154.82 & 154.76 & 160.57 & 162.35 & 171.25 & 174.05 & 171.80 & 168.99 & 166.35 \\ \text { MEAN } & 158.01 & 156.79 & 155.84 & 155.15 & 157.86 & 161.82 & 165.64 & 173.56 & 174.61 & 172.81 & 170.31 & 167.65 \\ \text { LOW } & 159.18 & 157.22 & 156.32 & 155.53 & 160.38 & 162.44 & 171.12 & 175.33 & 175.14 & 174.01 & 171.74 & 168.90\end{array}$

SUMMARY FOR 1995 HIGH 154.76 (May 1, 1995) MEAN 164.22 LOW 175.33 (Aug. 29, 1995)

Figure 61.-Water level in observation well 06K009, Early County. 
314602084473701 Local number, 07 N001.

LOCATION.-Lat $31^{\circ} 46^{\prime} 09^{\prime \prime}$, long $84^{\circ} 47^{\prime} 43^{\prime \prime}$, Hydrologic Unit 03110204.

SITE NAME.-City of Cuthbert.

INSTRUMENTATION.-Digital recorder.

AQUIFER.-Clayton.

WELL CHARACTERISTICS. -Drilled unused municipal well, diameter 8 in., depth $372 \mathrm{ft}$, casing depth unknown.

DATUM.-Altitude of land-surface datum is $460 \mathrm{ft}$.

REMARKS. - Well near city wells.

PERIOD OF RECORD. - January 1965 to current year. Continuous record since January 1965.

EXTREMES FOR PERIOD OF RECORD.-Highest water level, $132.0 \mathrm{ft}$ below land-surface datum, December 10, 1967; lowest, $163.00 \mathrm{ft}$ below land-surface datum, August 23, 1993.
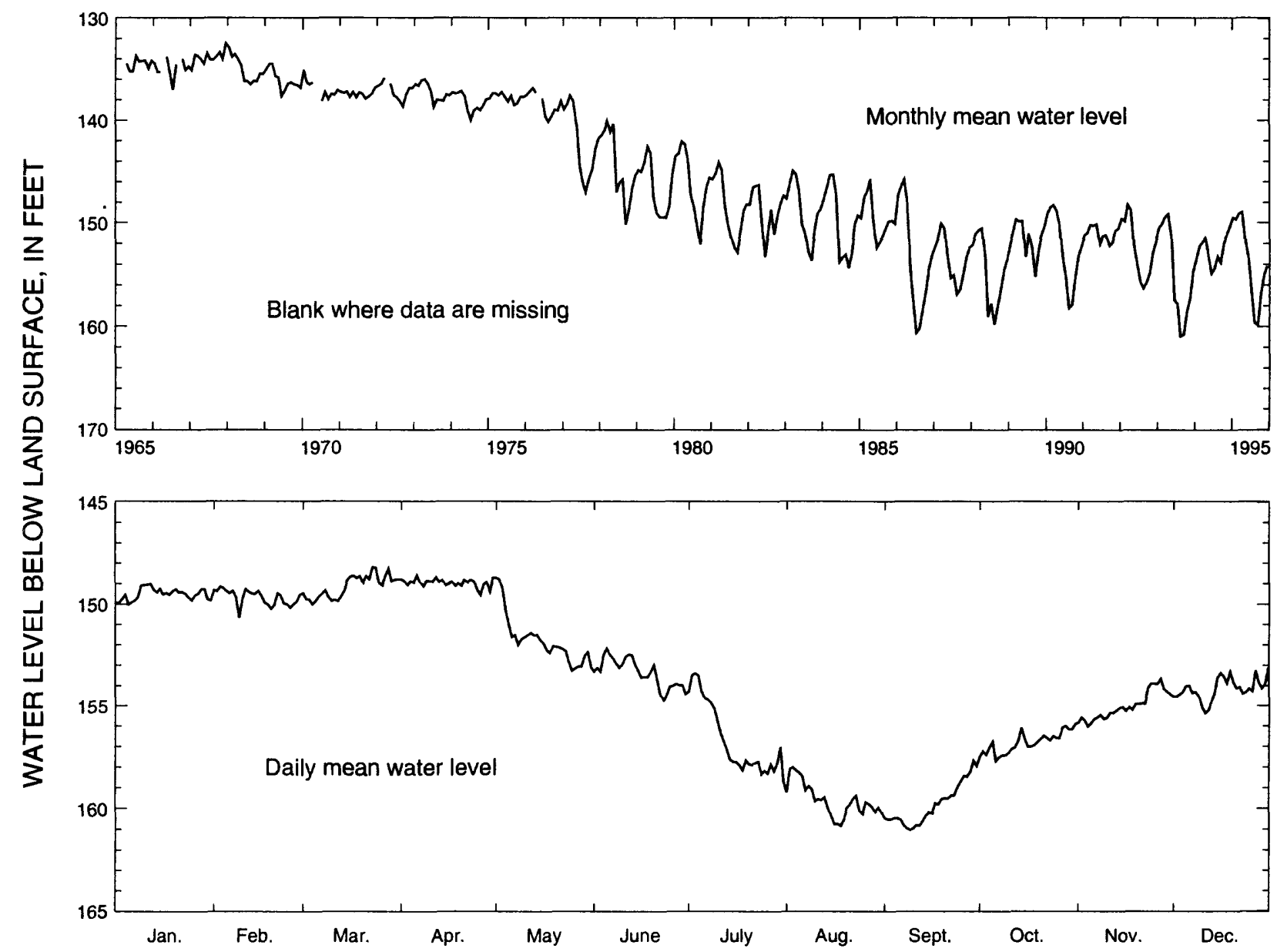

\begin{tabular}{|c|c|c|c|c|c|c|c|c|c|c|c|c|}
\hline 395 & JAN & FEB & MAR & APR & MAY & JUNE & JULY & $A \cup G$ & SEPT & OCT & NOV & DEC \\
\hline$G$ & 149.01 & 149.14 & 148.19 & 148.59 & 148.71 & 15 & 153.39 & 158.01 & 157.69 & 155.89 & 153.66 & 15 \\
\hline$=A 1$ & 149.51 & 149 & 149 & 148 & 151.77 & & 156 & 15 & 15 & 15 & 02 & \\
\hline ow & 150.01 & 150.66 & 150.00 & 149.55 & 153.26 & 154.71 & 158.71 & 160.83 & 161.03 & 157.71 & 156.02 & 155.36 \\
\hline \multicolumn{3}{|c|}{ SUMMARY FOR 1995} & \multicolumn{4}{|c|}{ HIGH 148.19 (Mar. 23, 1995) } & \multicolumn{2}{|c|}{ MEAN 153.73} & \multicolumn{4}{|c|}{ LOW 161.03 (Sept. 9, 1995) } \\
\hline
\end{tabular}

Figure 62.-Water level in observation well 07N001, Randolph County. 
314611084310301 Local number, 09 N001.

LOCATION. - Lat $31^{\circ} 46^{\prime} 09^{\prime \prime}$, long $84^{\circ} 31^{\prime} 07^{\prime \prime}$, Hydrologic Unit 03130009.

SITE NAME.-Bill Newman.

INSTRUMENTATION.-Digital recorder.

AQUIFER.-Clayton.

WELL CHARACTERISTICS.-Drilled unused supply well, diameter 6 in., depth $433 \mathrm{ft}$, cased to $333 \mathrm{ft}$, open hole.

DATUM.-Altitude of land-surface datum is $348 \mathrm{ft}$.

REMARKS. - Water levels for period, August 30 to September 25, are missing.

PERIOD OF RECORD. - January 1982 to current year. Continuous record since January 1982.

EXTREMES FOR PERIOD OF RECORD.-Highest water level, $142.54 \mathrm{ft}$ below land-surface datum, February 10, 1992; lowest, $248.83 \mathrm{ft}$ below land-surface datum, August 31, 1993.
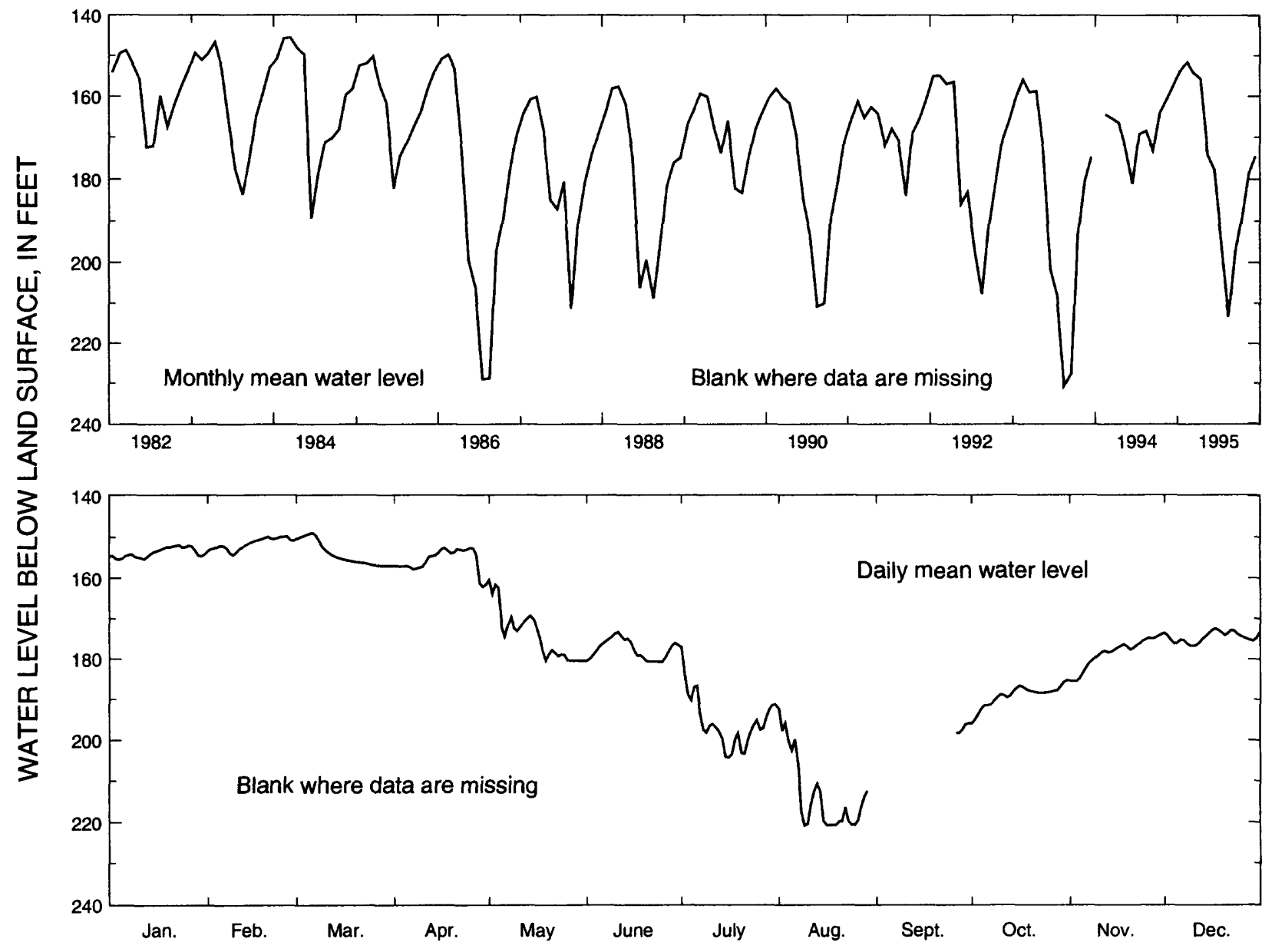

$\begin{array}{lrrrrrrrrrrrr}1995 & \text { JAN } & \text { FEB } & \text { MAR } & \text { APR } & \text { MAY } & \text { JUNE } & \text { JULY } & \text { AUG } & \text { SEPT } & \text { OCT } & \text { NOV } & \text { DEC } \\ \text { HIGH } & 151.94 & 149.81 & 148.97 & 152.64 & 160.46 & 173.22 & 177.01 & 192.23 & -\ldots-.- & 185.26 & 173.79 & 172.36 \\ \text { MEAN } & 153.80 & 151.63 & 154.18 & 155.68 & 173.96 & 177.64 & 195.45 & 213.35 & -\ldots-.- & 189.11 & 178.49 & 174.54 \\ \text { LOW } & 155.49 & 154.38 & 157.03 & 162.18 & 180.50 & 180.70 & 204.29 & 220.83 & ---.- & 195.91 & 185.49 & 176.71\end{array}$

SUMMARY FOR 1995 HIGH 148.97 (Mar. 6, 1995) MEAN $174.69 \quad$ LOW 220.83 (Aug. 9, 1995)

Figure 63.-Water level in observation well 09N001, Terrell County. 
313532084203501 Local number, 11 L002.

LOCATION.LLat $31^{\circ} 35^{\prime} 32^{\prime \prime}$, long $84^{\circ} 20^{\prime} 35^{\prime \prime}$, Hydrologic Unit 03130008.

SITE NAME.-Georgia Geologic Survey, Albany Nursery.

INSTRUMENTATION.-Digital recorder.

AQUIFER.-Clayton.

WELL CHARACTERISTICS.-Drilled observation well, diameter 3 in., depth $656 \mathrm{ft}$, cased to $542 \mathrm{ft}$, open hole.

DATUM.-Altitude of land-surface datum is $222 \mathrm{ft}$.

REMARKS.-Water levels for periods, September 27 to October 22 and November 5-20, are missing.

PERIOD OF RECORD. - September 1973 to current year. Continuous record since September 1973.

EXTREMES FOR PERIOD OF RECORD.-Highest water level, $58.90 \mathrm{ft}$ below land-surface datum, April 29, 1975;

lowest, $152.61 \mathrm{ft}$ below land-surface datum, August 23, 1986.
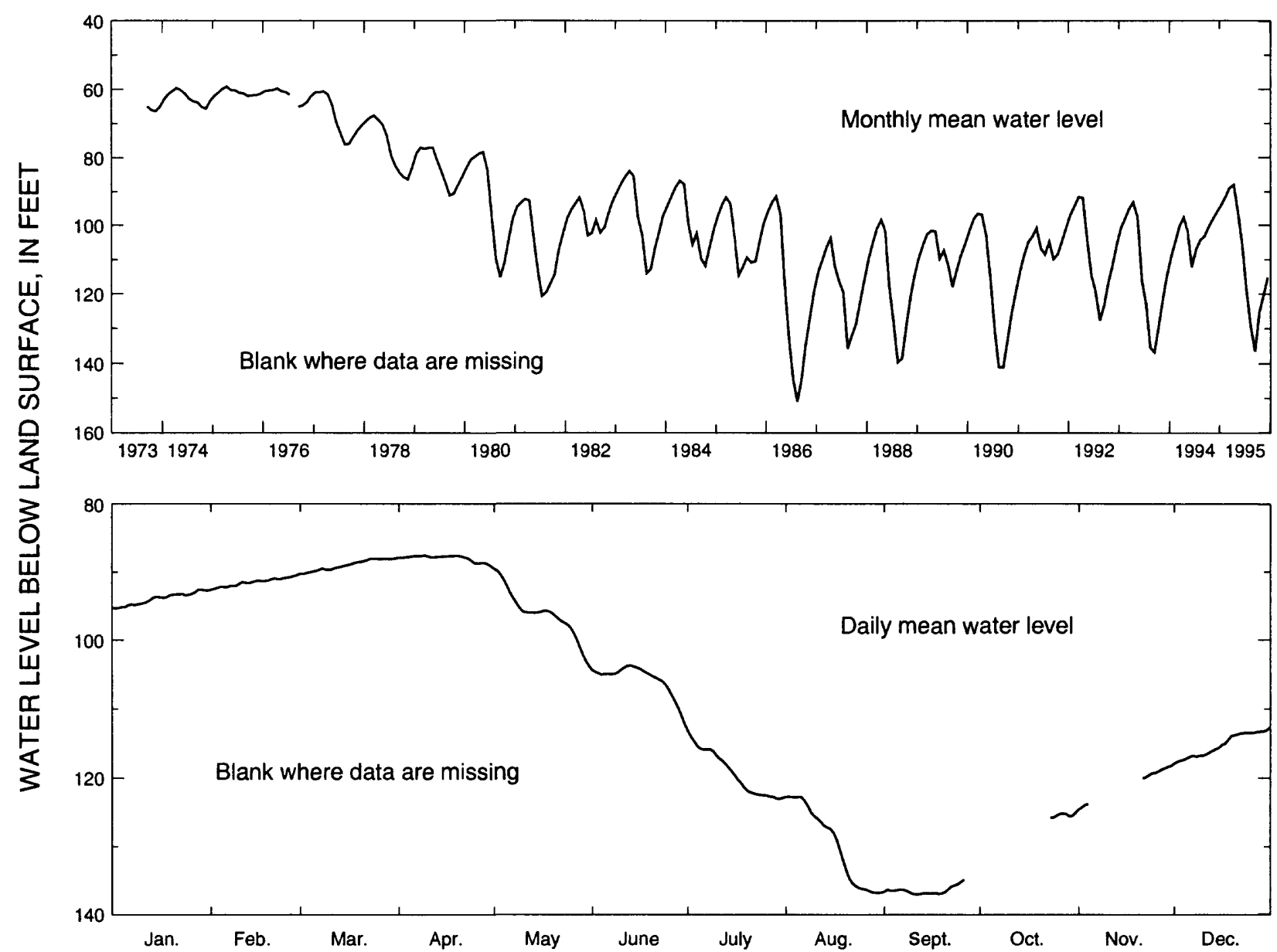

1995

$\begin{array}{lllllllllllll}1995 & \text { JAN } & \text { FEB } & \text { MAR } & \text { APR } & \text { MAY } & \text { JUNE } & \text { JULY } & \text { AUG } & \text { SEPT } & \text { OCT } & \text { NOV } & \text { DEC } \\ \text { HIGH } & 92.60 & 90.44 & 87.94 & 87.52 & 89.45 & 103.71 & 113.17 & 122.73 & 134.82 & \ldots \ldots . . & \ldots \ldots . . & 112.72 \\ \text { MEAN } & 93.92 & 91.49 & 88.95 & 87.93 & 96.17 & 105.72 & 119.23 & 129.67 & 136.46 & \ldots \ldots . & \ldots \ldots . . . & 115.18 \\ \text { LOW } & 95.33 & 92.61 & 90.25 & 89.12 & 103.84 & 112.12 & 123.02 & 136.80 & 137.04 & \ldots \ldots . . & \ldots \ldots . .- & 117.86\end{array}$

SUMMARY FOR 1995 HIGH 87.52 (Apr. 9, 1995) MEAN 107.35 LOW 137.04 (Sept. 11, 1995)

Figure 64.-Water level in observation well 11L002, Dougherty County. 
313554084062501 Local number, 13 L002.

LOCATION.-Lat $31^{\circ} 35^{\prime} 51^{\prime \prime}$, long 84 $84^{\circ} 24^{\prime \prime}$, Hydrologic Unit 03130008.

SITE NAME.-Albany Water, Gas, and Light Commission, Turner City 2.

INSTRUMENTATION.-Digital recorder.

AQUIFER.-Clayton.

WELL CHARACTERISTICS. - Drilled unused supply well, diameter $12 \mathrm{in}$., depth $760 \mathrm{ft}$, cased to $713 \mathrm{ft}$, open hole.

DATUM.-Altitude of land-surface datum is $212.84 \mathrm{ft}$.

REMARKS. - Water levels for period, October 17-22, are missing.

PERIOD OF RECORD.-December 1957 to current year. Continuous record December 1957 to December 1959, and since January 1962.

EXTREMES FOR PERIOD OF RECORD.-Highest water level, $38.19 \mathrm{ft}$ below land-surface datum, April 1, 1959;

lowest, $160.88 \mathrm{ft}$ below land-surface datum, July 26, 1986.

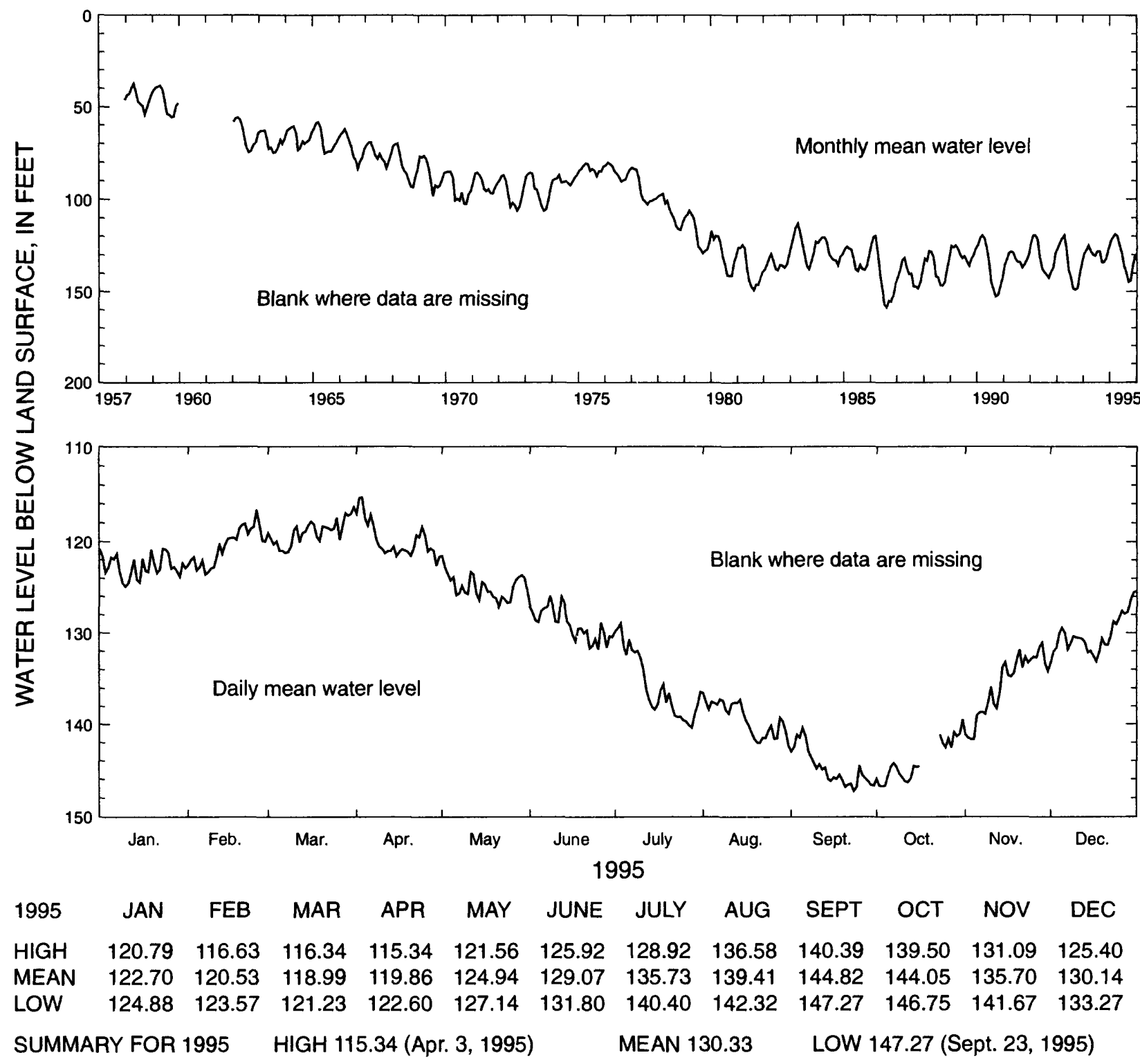

Figure 65.-Water level in observation well 13L002, Dougherty County. 
312654084210103 Local number, $11 \mathrm{~K} 005$.

LOCATION.-Lat $31^{\circ} 26^{\prime} 54^{\prime \prime}$, long $84^{\circ} 21^{\prime} 01^{\prime \prime}$, Hydrologic Unit 03130008.

SITE NAME.-U.S. Geological Survey, test well 12.

INSTRUMENTATION.-Digital recorder.

AQUIFER.-Clayton.

WELL CHARACTERISTICS.-Drilled observation well, diameter 6 in., depth $690 \mathrm{ft}$, cased to $630 \mathrm{ft}$, open hole.

DATUM.-Altitude of land-surface datum is $183 \mathrm{ft}$.

REMARKS.-None.

PERIOD OF RECORD.-May 1979 to current year. Continuous record since May 1979.

EXTREMES FOR PERIOD OF RECORD.-Highest water level, $23.03 \mathrm{ft}$ below land-surface datum, May 24, 1979; lowest, $60.37 \mathrm{ft}$ below land-surface datum, January 20-21,1994.

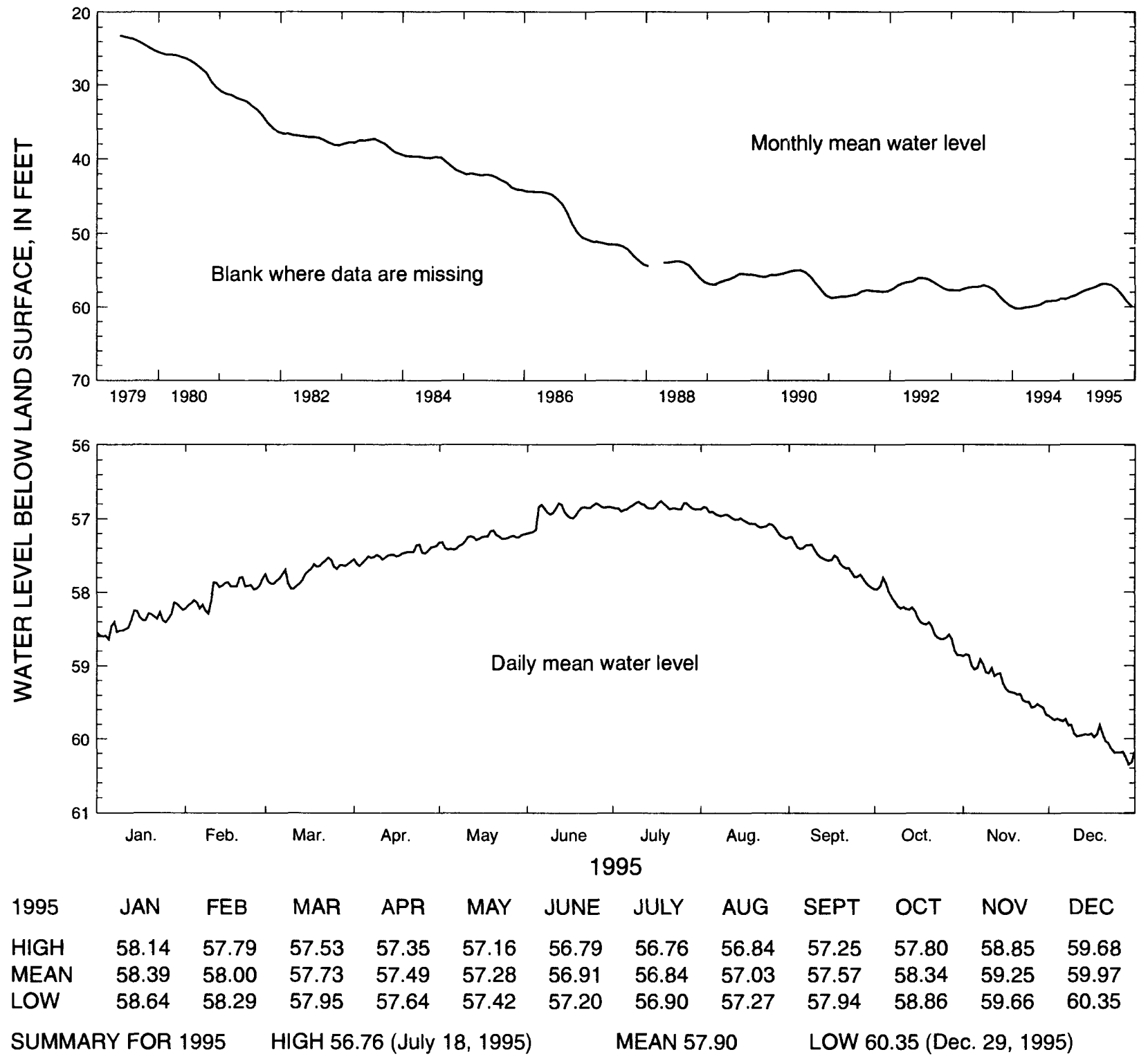

Figure 66.-Water level in observation well 11K005, Dougherty County. 
315731083542301 Local number, $14 \mathrm{P} 014$.

LOCATION.-Lat $31^{\circ} 57^{\prime} 31^{\prime \prime}$, long $83^{\circ} 54^{\prime} 23^{\prime \prime}$, Hydrologic Unit 03130006.

SITE NAME.-Georgia Geologic Survey, Veterans Memorial State Park, test well 1.

INSTRUMENTATION.-Digital recorder.

AQUIFER.-Clayton.

WELL CHARACTERISTICS.-Drilled observation well, diameter 6 in., depth $550 \mathrm{ft}$, cased to $500 \mathrm{ft}$, open hole.

DATUM. - Altitude of land-surface datum is $252 \mathrm{ft}$.

REMARKS. - Water levels for period, September 13-19, are missing.

PERIOD OF RECORD.-August 1984 to current year. Continuous record since August 1984.

EXTREMES FOR PERIOD OF RECORD. - Highest water level, $37.16 \mathrm{ft}$ below land-surface datum, September 2, 1984; lowest, $49.26 \mathrm{ft}$ below land-surface datum, November 29, 1988.

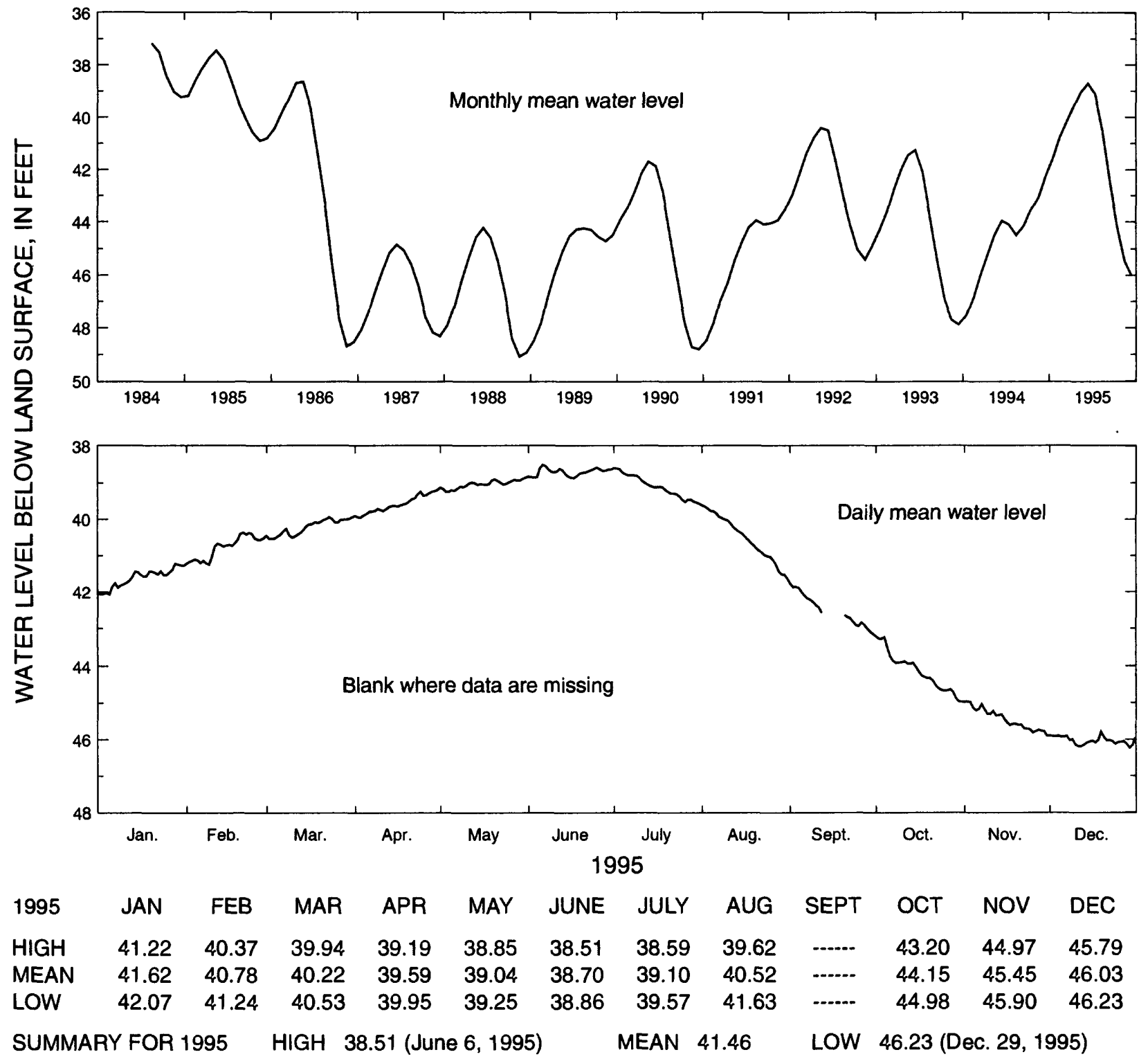

Figure 67.-Water level in observation well 14P014, Crisp County. 


\section{Cretaceous Aquifers and Aquifer Systems}

Water levels in Cretaceous aquifers and aquifer systems were monitored in 15 wells in 1995 and data from seven of these wells (fig. 68) are summarized in figures 69-75. The Cretaceous aquifers and aquifer systems include the Providence aquifer in southwestern Georgia and the Dublin, the Midville, and the Dublin-Midville aquifer systems in the northeastern part of the Coastal Plain. Water levels in these aquifers and aquifer systems are influenced by variations in precipitation and pumping (Clark and others, 1983, 1985).

In Chattahoochee County near Columbus, the annual mean water level in well $06 \mathrm{~S} 001$ (fig. 69) was $0.9 \mathrm{ft}$ lower in 1995 than in 1994. A record-low daily mean water level was recorded in this well that was $1.6 \mathrm{ft}$ lower than the previous low.

\section{Providence aquifer}

The water level in the Providence aquifer in the Albany area (fig. 68) was monitored in one well in 1995. Water levels in the aquifer are influenced by variations in precipitation and pumping (Clarke and others, 1983). In 1995, the annual mean water level in well 12L021 (fig. 70) was $1.6 \mathrm{ft}$ lower than in 1994.

\section{Dublin aquifer system}

The water level was monitored in four wells in the Dublin aquifer system in 1995 and data from one of these wells (fig. 68) are summarized in figure 71. In the eastern Houston County and western Twiggs County area, water levels in wells tapping the aquifer are affected by precipitation and pumping (Clarke and others, 1985). The annual mean water level in well 18U001 (fig. 71) was $0.3 \mathrm{ft}$ higher in 1995 than in 1994.

\section{Midville aquifer system}

The water level was monitored in four wells in the Midville aquifer system in 1995 (fig. 68). Data from two of these wells are summarized in figures 72 and 73 . The water level in the Midville aquifer system is affected mainly by regional pumping (Clarke and others, 1985). In 1995, the annual mean water level in these wells, 18T001 and 28X001, was about the same and $0.4 \mathrm{ft}$ higher than in 1994, respectively.

\section{Dublin-Midville aquifer system}

The water level in the Dublin-Midville aquifer system (fig. 68) was monitored in two wells in 1995 and data from these wells are summarized in figures 74 and 75. Water levels in wells tapping the Dublin-Midville aquifer system in Richmond County are influenced mainly by precipitation and by local pumping (Gorday, 1985, p. 28). The annual mean water level in well 30AA04 (fig. 74) near McBean in southern Richmond County, was $0.5 \mathrm{ft}$ higher in 1995 than in 1994.

At Sandersville, Washington County, the water level in the Dublin-Midville aquifer system is influenced primarily by local pumping. During 1995, the annual mean water level in well $23 \mathrm{X} 027$ (fig. 75 ) was $0.6 \mathrm{ft}$ lower than in 1994. A record-low daily mean water level was recorded in this well that was $1.2 \mathrm{ft}$ lower than the previous record low. 


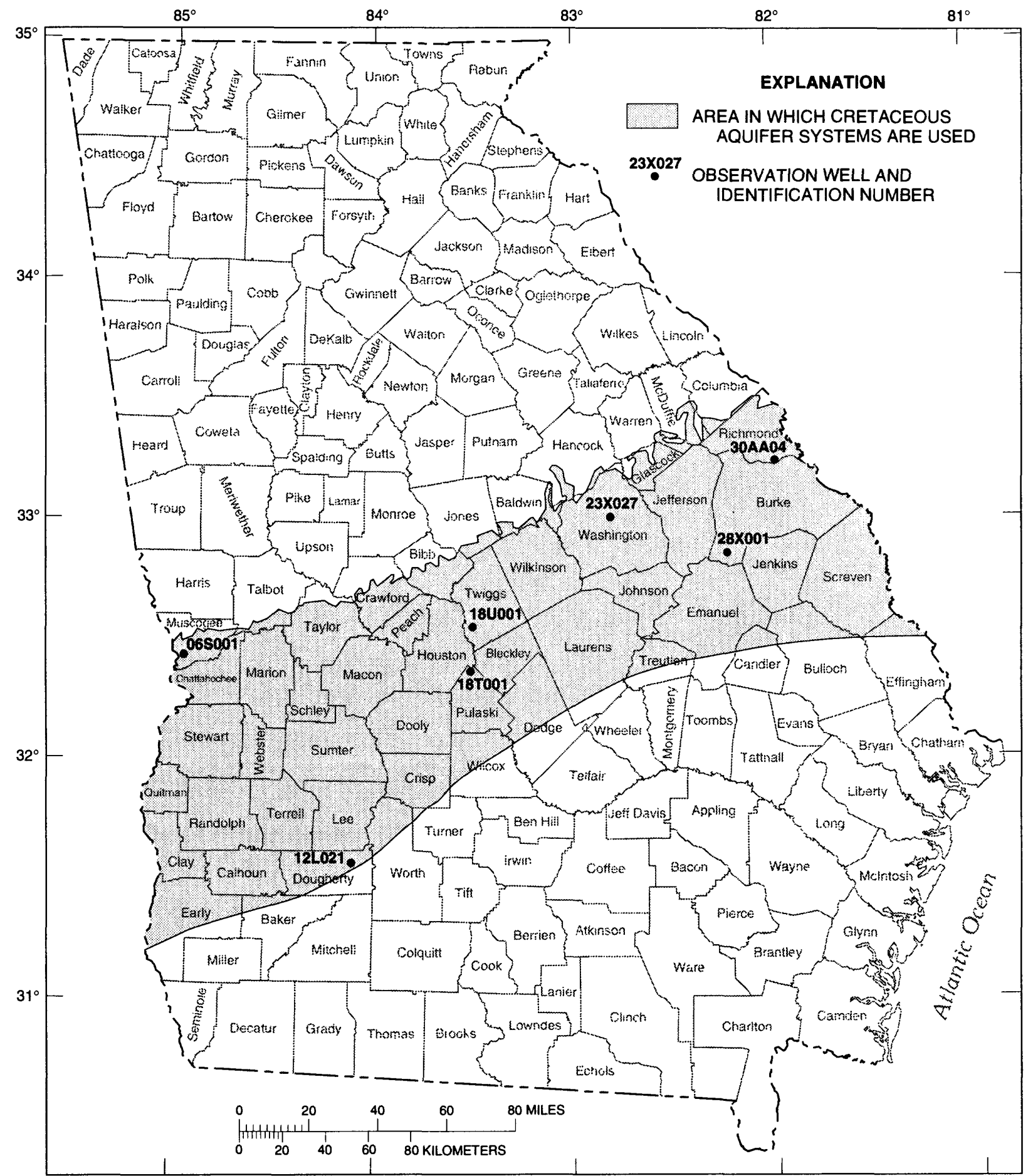

Base modified from U.S.Geological Survey State base map

Figure 68.-Locations of observation wells completed in Cretaceous aquifers and aquifer systems. 
322036084590301 Local number, 065001.

LOCATION.-Lat $32^{\circ} 20^{\prime} 31^{\prime \prime}$, long $84^{\circ} 59^{\prime} 10^{\prime \prime}$, Hydrologic Unit 03130003.

SITE NAME.-U.S. Army, Fort Benning.

INSTRUMENTATION.-Digital recorder.

AQUIFER.- Cretaceous formations (Blufftown, Eutaw, and Tuscaloosa Formations).

WELL CHARACTERISTICS.-Drilled unused supply well, diameter 12 in., depth $568 \mathrm{ft}$, screened intervals 215-220 ft, 230-235 ft, 280-290 ft, and 540-550 ft.

DATUM.-Altitude of land-surface datum is $255 \mathrm{ft}$.

REMARKS.-None.

PERIOD OF RECORD.-August 1953 to current year. Continuous record since August 1953.

EXTREMES FOR PERIOD OF RECORD.- Highest water level, $0.37 \mathrm{ft}$ below land-surface datum, April 10, 1964; lowest, $38.25 \mathrm{ft}$ below land-surface datum, September 30 to October 1, 1995.

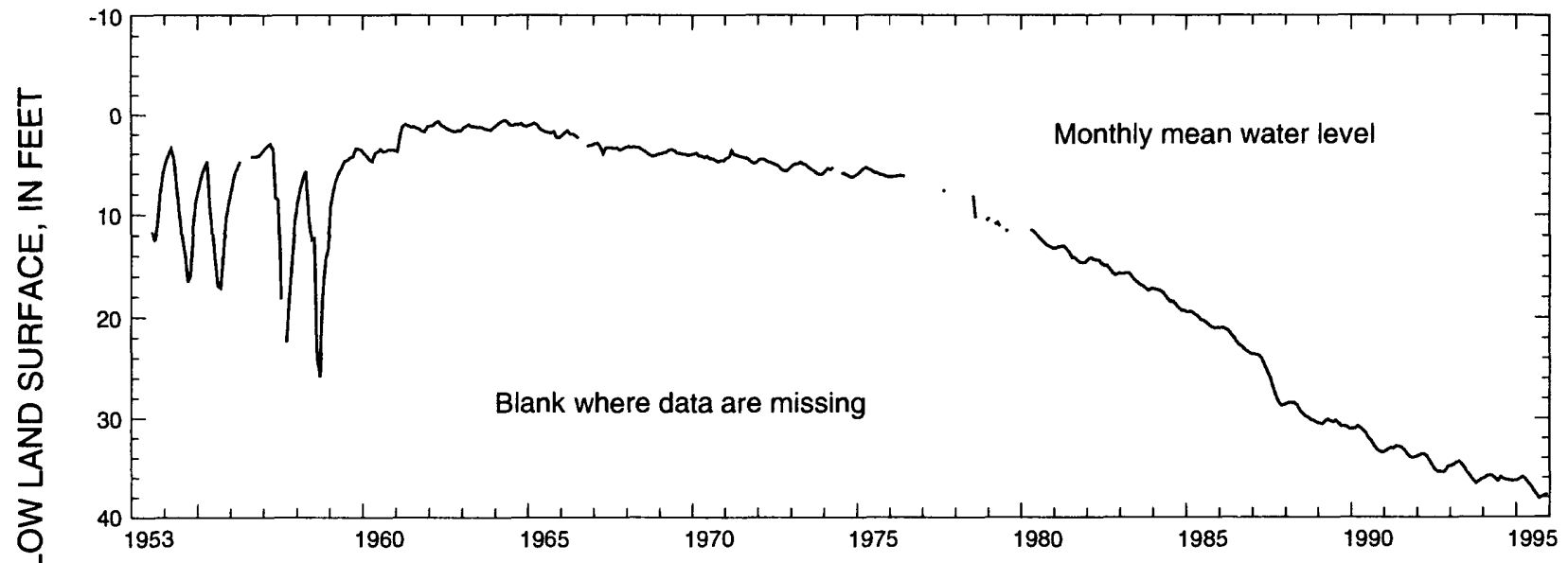

造

1995

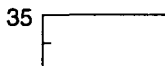

36

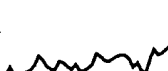<smiles>CCCCCCCC</smiles>

Daily mean water level

$\begin{array}{lllllllllllll}\text { HIGH } & 36.16 & 35.82 & 35.86 & 36.03 & 36.23 & 36.69 & 37.07 & 37.57 & 37.91 & 37.79 & 37.63 & 37.50 \\ \text { MEAN } & 36.28 & 36.10 & 35.94 & 36.15 & 36.53 & 36.87 & 37.32 & 37.71 & 38.10 & 37.90 & 37.76 & 37.69 \\ \text { LOW } & 36.41 & 36.31 & 36.04 & 36.24 & 36.77 & 37.05 & 37.57 & 37.92 & 38.25 & 38.25 & 37.85 & 37.85\end{array}$
HIGH 35.82 (Feb. 20, 1995)

Figure 69.-Water level in observation well 06S001, Chattahoochee County. 
313534084103003 Local number, 12 L021.

LOCATION.-Lat $31^{\circ} 35^{\prime} 37^{\prime \prime}$, long $84^{\circ} 10^{\prime} 29^{\prime \prime}$, Hydrologic Unit 03130008.

SITE NAME.-U.S. Geological Survey, test well 10.

INSTRUMENTATION.-Electronic data recorder.

AQUIFER.-Providence.

WELL CHARACTERISTICS.-Drilled observation well, diameter 6 in., depth $834 \mathrm{ft}$, cased to $810 \mathrm{ft}$, screen to $830 \mathrm{ft}$.

DATUM.-Altitude of land-surface datum is $198 \mathrm{ft}$.

REMARKS.-None.

PERIOD OF RECORD.-December 1978 to current year. Continuous record since December 1978.

EXTREMES FOR PERIOD OF RECORD.-Highest water level, $101.59 \mathrm{ft}$ below land-surface datum, April 26, 1984; lowest, $156.36 \mathrm{ft}$ below land-surface datum, July 26, 1986.

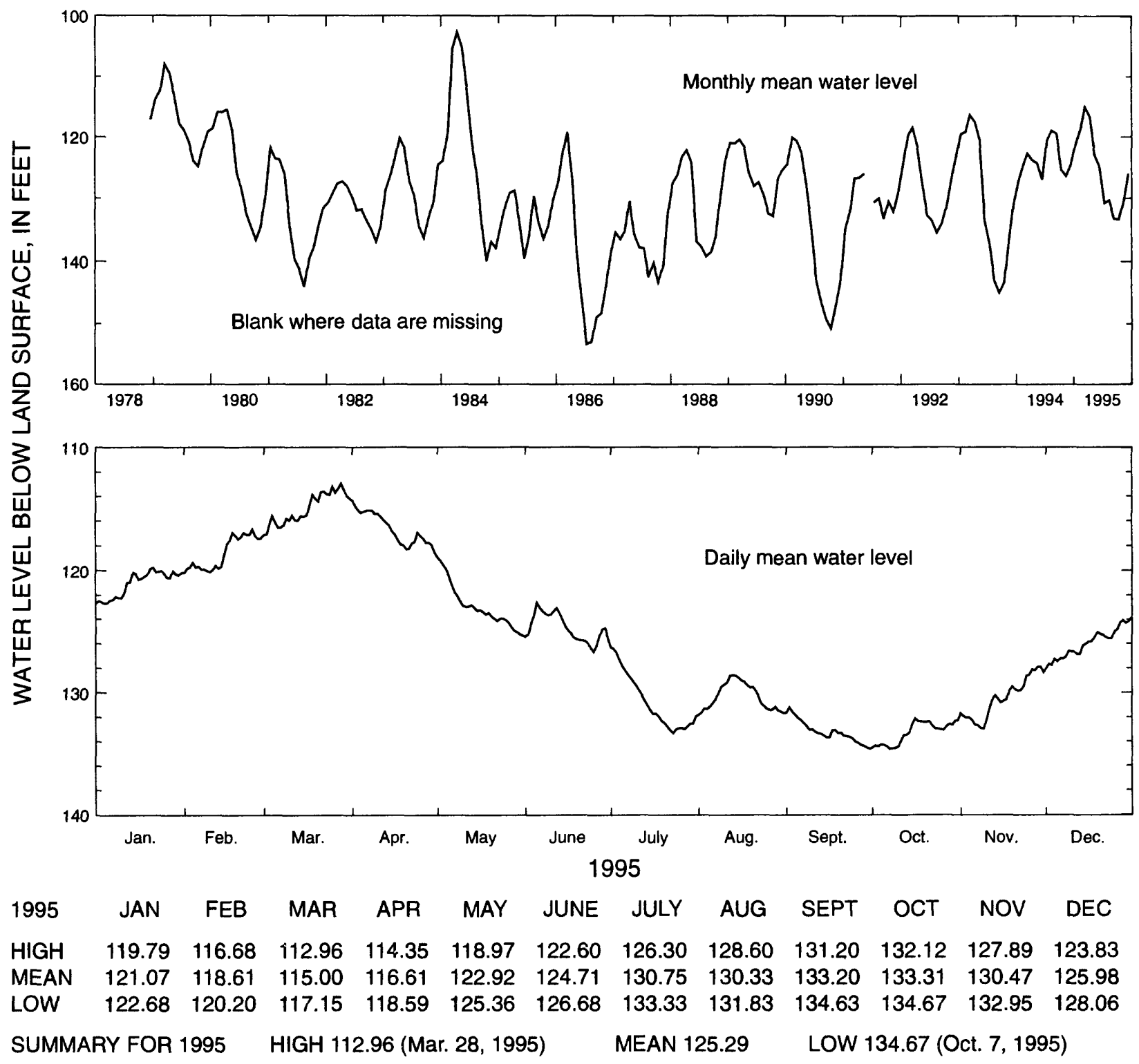

Figure 70.-Water level in observation well 12L021, Dougherty County. 
323302083263401 Local number, 184001.

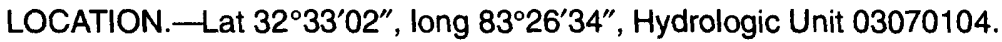

SITE NAME.-Georgia Kraft, U.S. Geological Survey, test well 3.

INSTRUMENTATION.-Digital recorder.

AQUIFER.-Dublin aquifer system.

WELL CHARACTERISTICS. -Drilled observation well, diameter 6 in., depth $616 \mathrm{ft}$, cased to $586 \mathrm{ft}$, screen to $616 \mathrm{ft}$.

DATUM.-Altitude of land-surface datum is $442 \mathrm{ft}$.

REMARKS.-None.

PERIOD OF RECORD.-July 1975 to current year. Continuous record since July 1975.

EXTREMES FOR PERIOD OF RECORD.-Highest water level, $162.0 \mathrm{ft}$ below land-surface datum, April 4, 1977;

lowest, $166.44 \mathrm{ft}$ below land-surface datum, October 3, 1990.

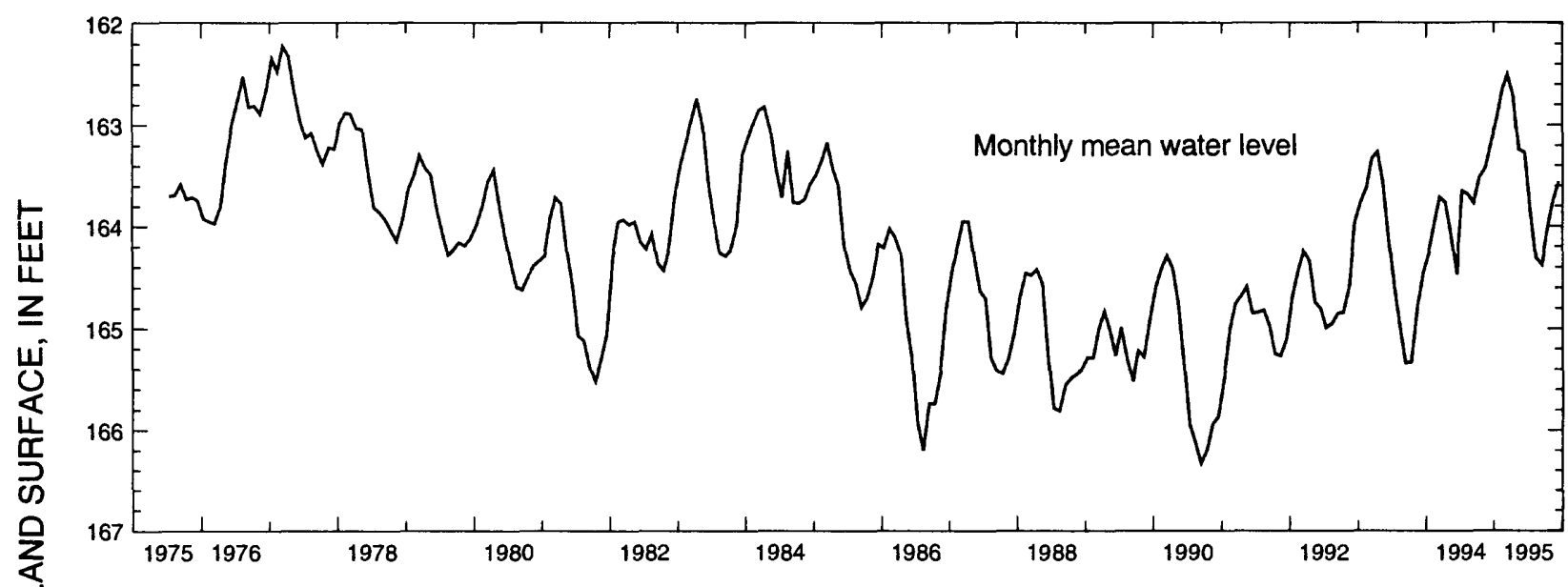

岁

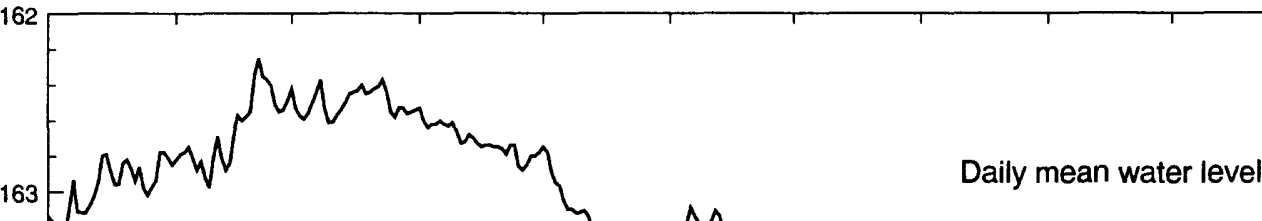

$\begin{array}{llllllllllllll}\text { HIGH } & 162.78 & 162.25 & 162.37 & 162.53 & 162.75 & 163.09 & 163.36 & 164.09 & 164.21 & 163.81 & 163.56 & 163.29 \\ \text { MEAN } & 162.97 & 162.66 & 162.50 & 162.71 & 163.24 & 163.27 & 163.83 & 164.31 & 164.38 & 164.03 & 163.74 & 163.56 \\ \text { LOW } & 163.25 & 162.98 & 162.61 & 162.88 & 163.61 & 163.41 & 164.10 & 164.53 & 164.48 & 164.29 & 164.03 & 163.74\end{array}$

SUMMARY FOR 1995 HIGH 162.25 (Feb. 21, 1995) MEAN $163.44 \quad$ LOW 164.53 (Aug. 22-24, 1995)

Figure 71. -Water level in observation well 18U001, Twiggs County. 
322245083290101 Local number, 18 T001.

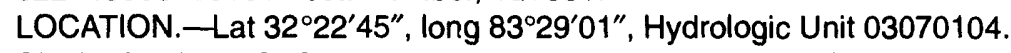

SITE NAME.-U.S. Geological Survey, Arrowhead, test well 1.

INSTRUMENTATION.-Digital recorder.

AQUIFER.-Midville aquifer system.

WELL CHARACTERISTICS. - Drilled observation well, diameter 6 in., depth 1,555 ft, cased to $970 \mathrm{ft}$, screened intervals, $970-980 \mathrm{ft}, 1,110-1,130 \mathrm{ft}$, and 1,270-1,280 ft.

DATUM.-Altitude of land-surface datum is $334 \mathrm{ft}$.

REMARKS. - Water levels for period, May 7-28, are missing.

PERIOD OF RECORD.- June 1981 to current year. Continuous record since June 1981.

EXTREMES FOR PERIOD OF RECORD. - Highest water level, $53.90 \mathrm{ft}$ below land-surface datum, July 9, 1994;

lowest, $59.52 \mathrm{ft}$ below land-surface datum, October 7-8, 1990.

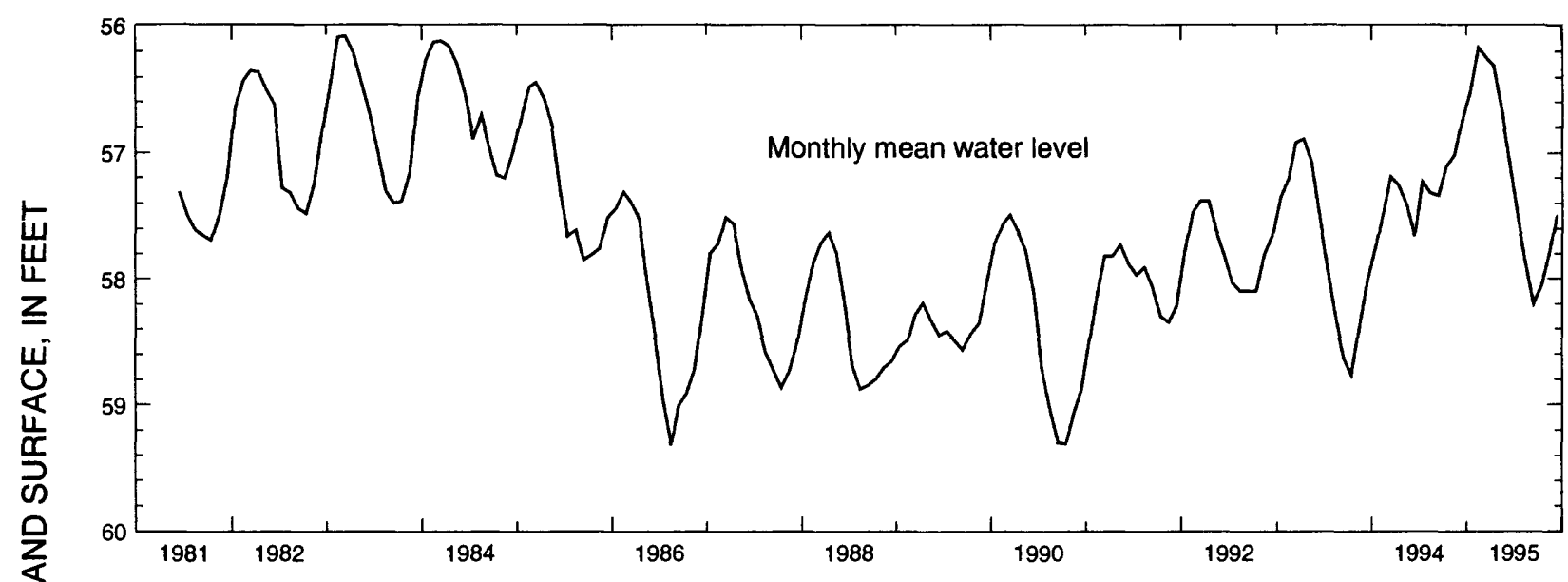

\begin{tabular}{lcccccccccccc}
1995 & JAN & FEB & MAR & APR & MAY & JUNE & JULY & AUG & SEPT & OCT & NOV & DEC \\
HIGH & 56.32 & 55.16 & 56.07 & 56.20 & $\ldots \ldots-.-$ & 56.76 & 57.26 & 57.73 & 57.99 & 57.39 & 57.52 & 57.19 \\
MEAN & 56.51 & 56.17 & 56.24 & 56.31 & $\ldots-.-$ & 57.07 & 57.48 & 57.87 & 58.20 & 58.06 & 57.80 & 57.49 \\
LOW & 56.78 & 56.60 & 56.43 & 56.44 & $\ldots-. .-$ & 57.24 & 57.73 & 58.01 & 58.30 & 58.29 & 58.07 & 57.72 \\
\multicolumn{3}{l}{ SUMMARY FOR 1995 } & HIGH & 55.16 (Feb. 21, 1995) & MEAN & 57.19 & LOW & 58.30 (Sept. 24, 1995)
\end{tabular}

Figure 72.-Water level in observation well 18T001, Pulaski County. 
325232082131501 Local number, $28 \times 001$.

LOCATION.-Lat $32^{\circ} 52^{\prime} 32^{\prime \prime}$, long $82^{\circ} 13^{\prime} 15^{\prime \prime}$, Hydrologic Unit 03060201.

SITE NAME.-U.S. Geological Survey, Midville, test well 1.

INSTRUMENTATION.-Digital recorder.

AQUIFER.-Midville aquifer system.

WELL CHARACTERISTICS.-Drilled observation well, diameter 4 in., depth 1,045 ft, cased to $1,025 \mathrm{ft}$, screen to $1,045 \mathrm{ft}$.

DATUM.-Altitude of land-surface datum is $269 \mathrm{ft}$.

REMARKS.-None.

PERIOD OF RECORD. June 1980 to current year. Continuous record since June 1980.

EXTREMES FOR PERIOD OF RECORD. - Highest water level, $49.07 \mathrm{ft}$ below land-surface datum, June 4, 1980; lowest, $59.91 \mathrm{ft}$ below land-surface datum, November 30, 1990.

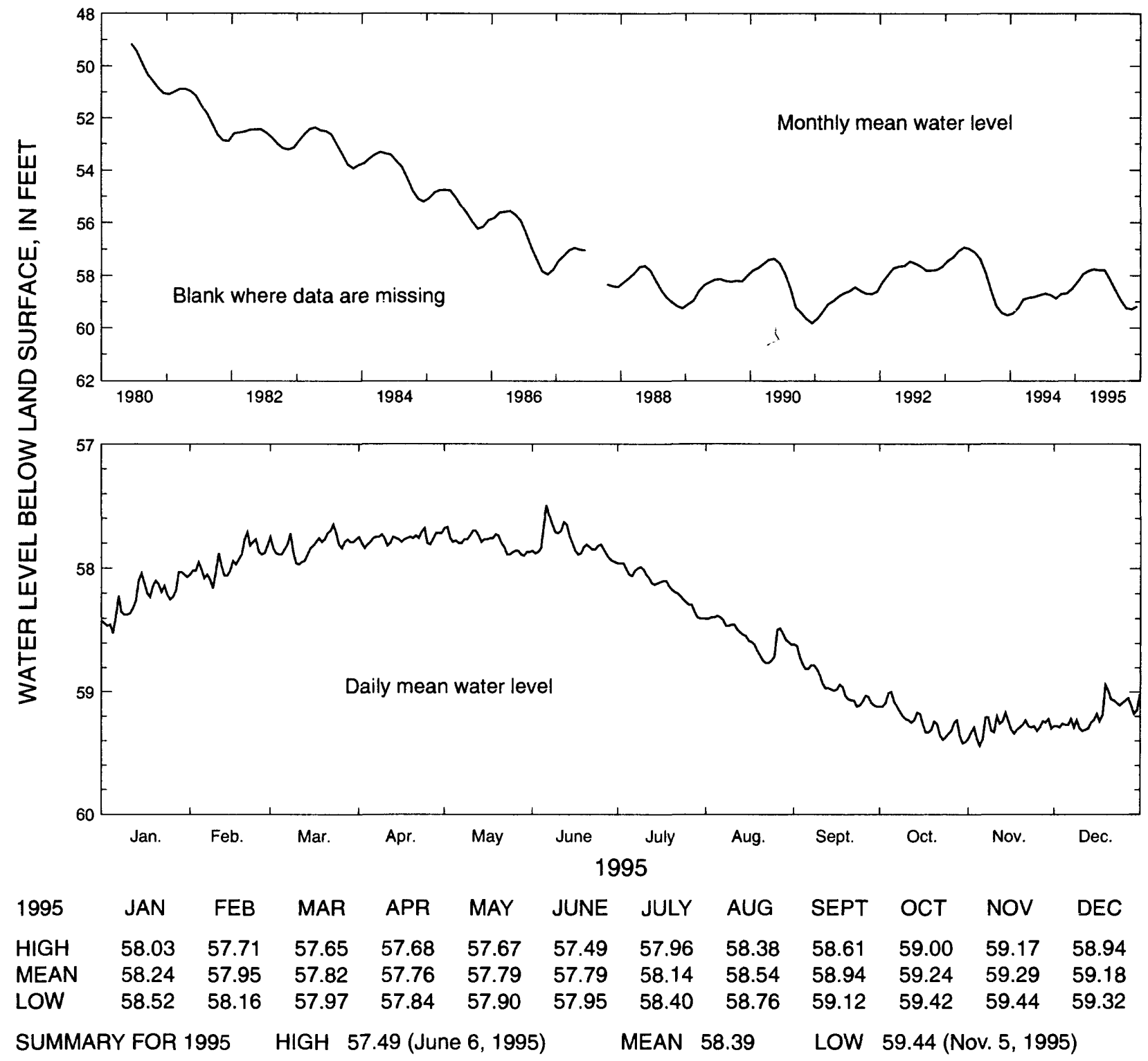

Figure 73.-Water level in observation well 28X001, Burke County. 
331711081573701 Local number, 30AA04.

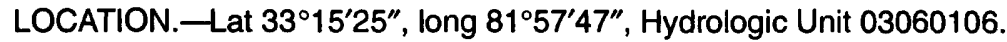

SITE NAME.-Richmond County water system, U.S. Geological Survey, McBean 2.

INSTRUMENTATION.-Digital recorder.

AQUIFER.-Dublin-Midville aquifer system.

WELL CHARACTERISTICS.-Drilled unused municipal well, diameter 6 in., depth $496 \mathrm{ft}$, cased to $174 \mathrm{ft}$, screened intervals, $174-192 \mathrm{ft}, 299-319 \mathrm{ft}, 341-372 \mathrm{ft}$, and $393-434 \mathrm{ft}$.

DATUM.-Altitude of land-surface datum is $293 \mathrm{ft}$.

REMARKS.-None.

PERIOD OF RECORD. - June 1979 to current year. Continuous record since June 1979.

EXTREMES FOR PERIOD OF RECORD. - Highest water level, $116.70 \mathrm{ft}$ below land-surface datum, May 30, 1984; lowest, $129.61 \mathrm{ft}$ below land-surface datum, August 28, 1988.
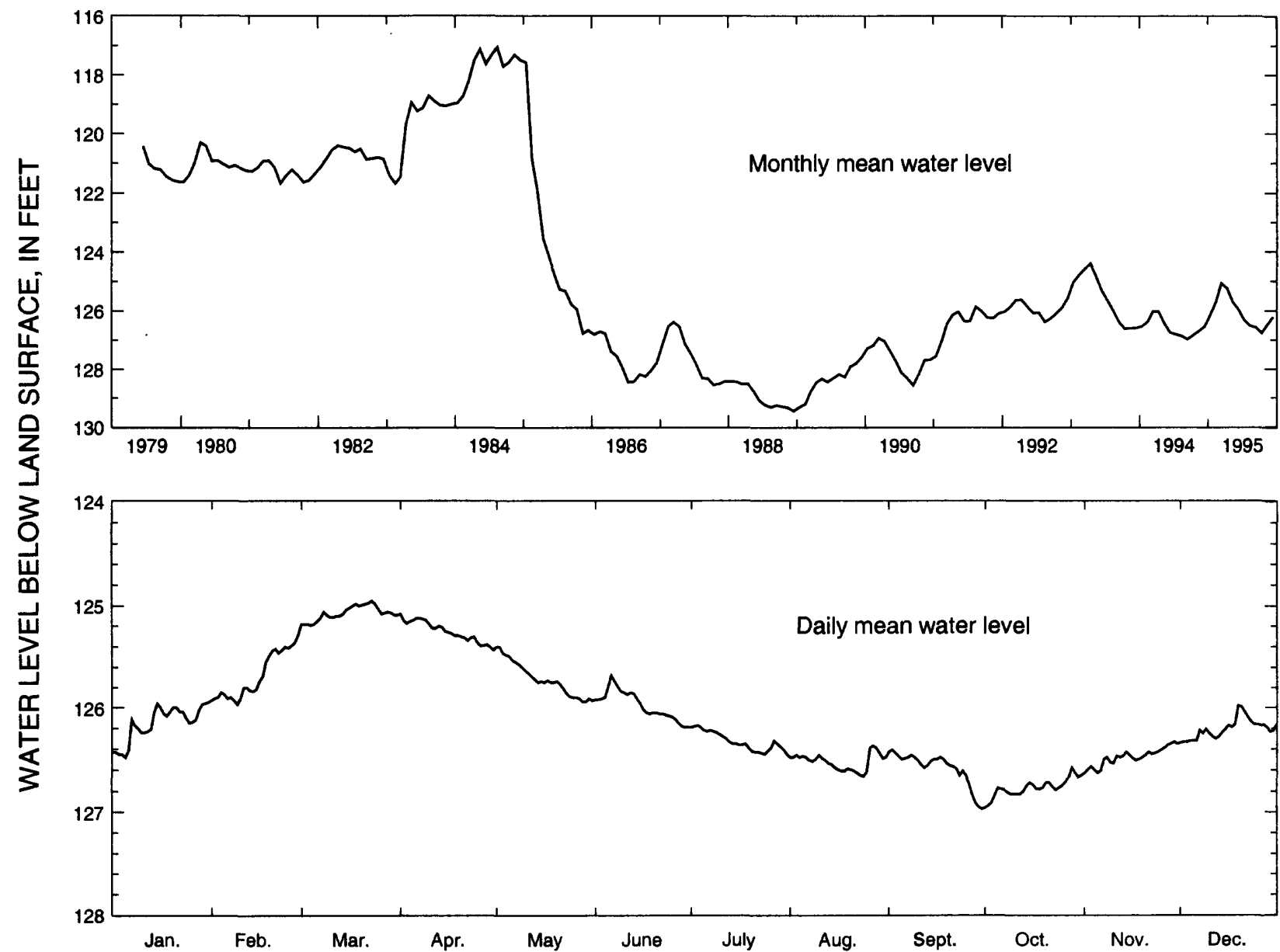

$\begin{array}{lcccccccccccc}1995 & \text { JAN } & \text { FEB } & \text { MAR } & \text { APR } & \text { MAY } & \text { JUNE } & \text { JULY } & \text { AUG } & \text { SEPT } & \text { OCT } & \text { NOV } & \text { DEC } \\ \text { HIGH } & 125.95 & 125.29 & 124.95 & 125.08 & 125.40 & 125.68 & 126.17 & 126.37 & 126.41 & 126.58 & 126.33 & 125.98 \\ \text { MEAN } & 126.15 & 125.69 & 125.07 & 125.25 & 125.71 & 125.97 & 126.33 & 126.52 & 126.58 & 126.77 & 126.48 & 126.21 \\ \text { LOW } & 126.48 & 125.97 & 125.19 & 125.43 & 125.94 & 126.19 & 126.45 & 126.66 & 126.97 & 126.96 & 126.63 & 126.34 \\ \text { SUMMARY FOR 1995 } & \text { HIGH 124.95 (Mar. 23, 1995) } & \text { MEAN 126.06 } & \text { LOW } 126.97 \text { (Sept. 30, 1995) }\end{array}$

Figure 74.-Water level in observation well 30AA04, Richmond County. 
325848082480901 Local number, $23 \times 027$.

LOCATION. - Lat $32^{\circ} 58^{\prime} 48^{\prime \prime}$, long $82^{\circ} 48^{\prime} 08^{\prime \prime}$, Hydrologic Unit 03070102.

SITE NAME.-City of Sandersville, well 8.

INSTRUMENTATION.-Digital recorder.

AQUIFER.-Dublin-Midville aquifer system.

WELL CHARACTERISTICS.-Drilled unused municipal well, diameter 8 in., depth $750 \mathrm{ft}$, cased to $480 \mathrm{ft}$, screened intervals, $480-485 \mathrm{ft}, 605-610 \mathrm{ft}, 650-655 \mathrm{ft}, 695-700 \mathrm{ft}$, and $740-745 \mathrm{ft}$. Lower screens probably caved.

DATUM.-Altitude of land-surface datum is $450 \mathrm{ft}$.

REMARKS.-None.

PERIOD OF RECORD.-March 1985 to current year. Continuous record since March 1985.

EXTREMES FOR PERIOD OF RECORD. - Highest water level, $227.68 \mathrm{ft}$ below land-surface datum, April 9, 1985; lowest, $253.97 \mathrm{ft}$ below land-surface datum, August 17,1995.

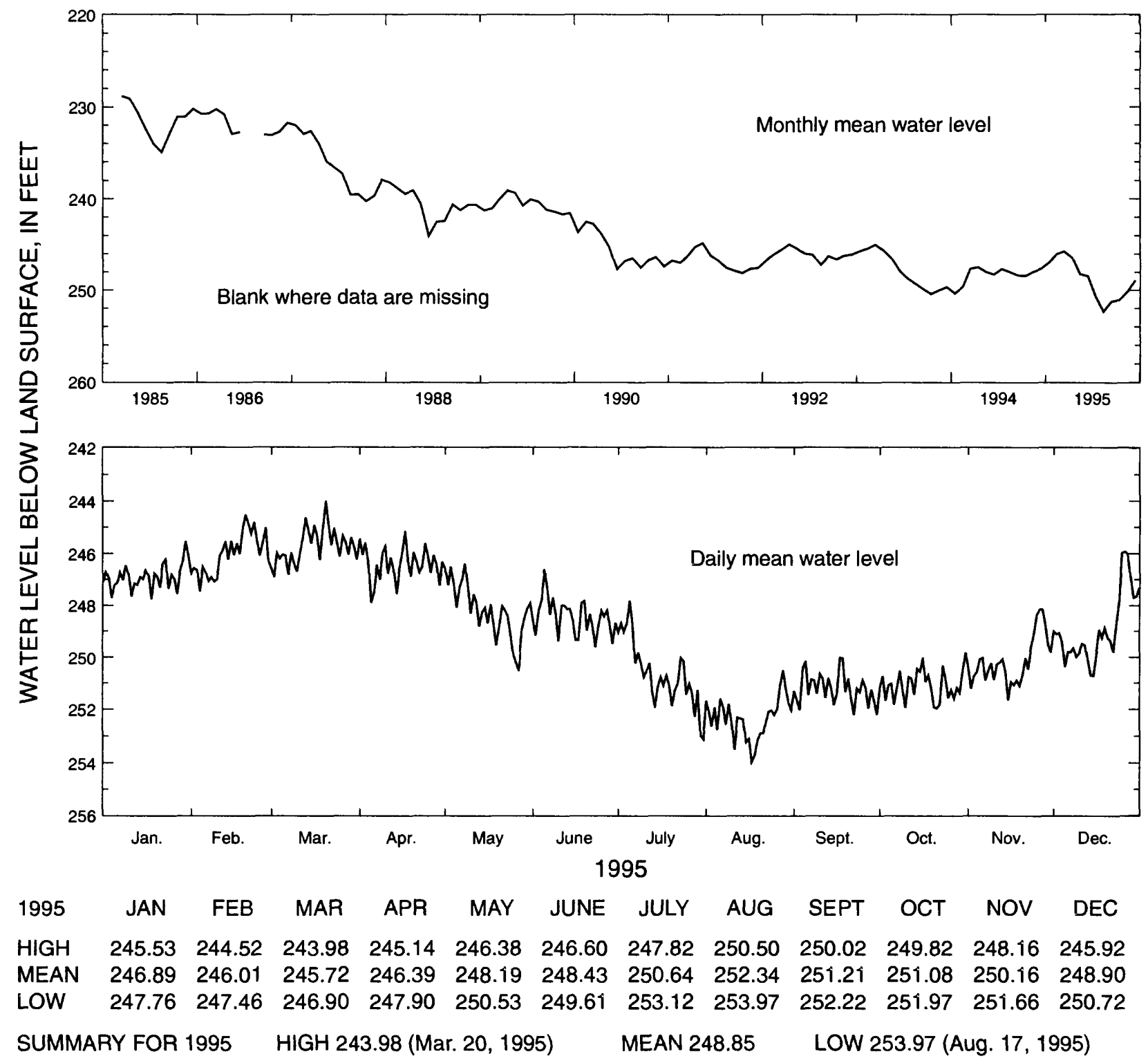

Figure 75.-Water level in observation well $23 \times 027$, Washington County. 


\section{Paleozoic-Rock Aquifer}

The water level in an unconfined Paleozoic-rock aquifer in Walker County (fig. 77) was monitored in well 03PP01 in 1995 (fig. 77). In this area, water levels in wells tapping the Paleozoic-rock aquifers are affected mainly by precipitation and local pumping (Cressler, 1964). Precipitation can cause rapid rises in water levels in areas where thin regolith overlies aquifers having secondary openings (fractures or solution openings), and the effect is illustrated in the hydrograph of daily mean water levels for well 03PP01 (fig. 77). The annual mean water level in this well was $1.3 \mathrm{ft}$ lower in 1995 than in 1994. A record-high daily mean water level was recorded in this well that was $0.4 \mathrm{ft}$ higher than the previous record high.

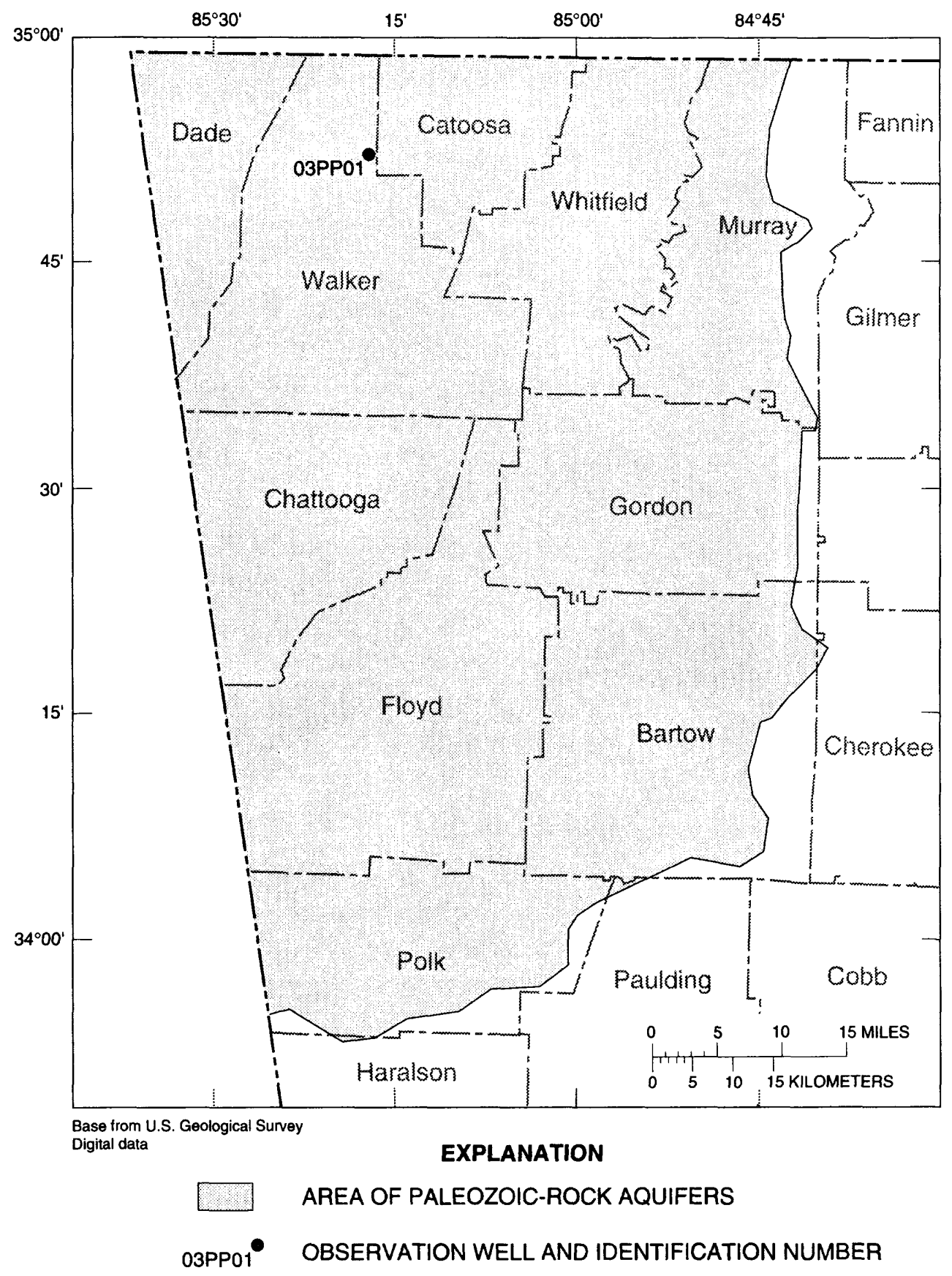

Figure 76.-Location of observation well completed in a Paleozoic-rock aquifer. 
345403085160001 Local number, 03PP01.

LOCATION.-Lat $34^{\circ} 54^{\prime} 08^{\prime \prime}$, long 85 $85^{\circ} 16^{\prime} 00^{\prime \prime}$, Hydrologic Unit 06020001.

SITE NAME.- National Park Service, Chickamauga Battlefield Park.

INSTRUMENTATION.-Digital recorder.

AQUIFER.-Paleozoic rock (Chickamauga Limestone).

WELL CHARACTERISTICS.-Cable-tooled, obsenvation well, diameter 8 in., depth $72 \mathrm{ft}$, cased to $11 \mathrm{ft}$, open hole.

DATUM.-Altitude of land-surface datum is $730 \mathrm{ft}$.

REMARKS.-None.

PERIOD OF RECORD.-November 1977 to current year. Continuous record since November 1977.

EXTREMES FOR PERIOD OF RECORD.-Highest water level, $1.52 \mathrm{ft}$ below land-surface datum, February 16,1995; lowest, $21.70 \mathrm{ft}$ below land-surface datum, August 5, 1978.
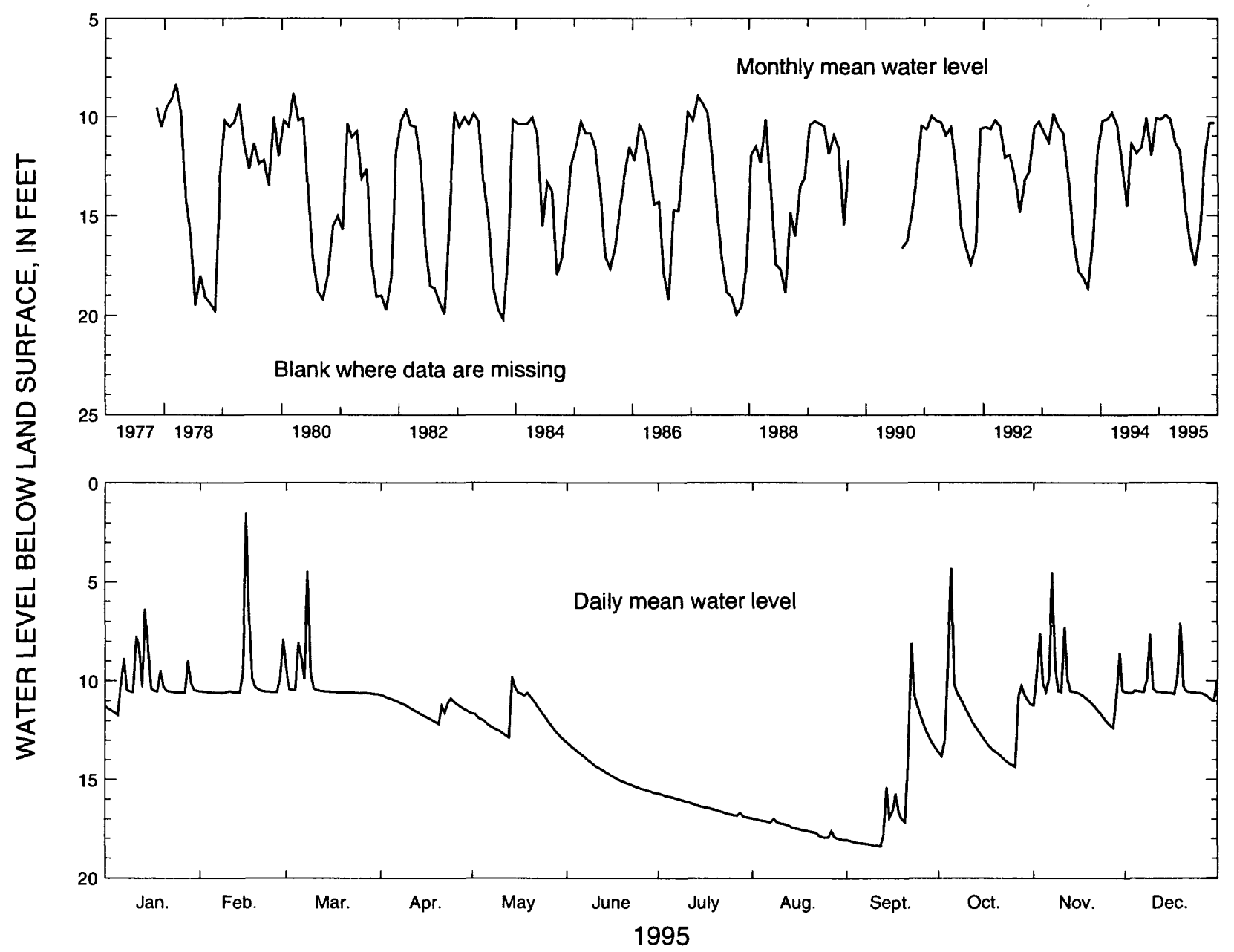

$\begin{array}{lrrrrrrrrrrrr}1995 & \text { JAN } & \text { FEB } & \text { MAR } & \text { APR } & \text { MAY } & \text { JUNE } & \text { JULY } & \text { AUG } & \text { SEPT } & \text { OCT } & \text { NOV } & \text { DEC } \\ \text { HIGH } & 6.36 & 1.52 & 4.45 & 10.70 & 9.77 & 13.10 & 15.71 & 16.98 & 8.08 & 4.29 & 4.50 & 7.07 \\ \text { MEAN } & 10.14 & 9.91 & 10.13 & 11.34 & 11.77 & 14.63 & 16.36 & 17.49 & 15.74 & 12.08 & 10.32 & 10.32 \\ \text { LOW } & 11.71 & 10.61 & 10.67 & 12.17 & 12.97 & 15.68 & 16.94 & 18.07 & 18.39 & 14.35 & 12.36 & 11.00\end{array}$

SUMMARY FOR 1995 HIGH 1.52 (Feb. 16, 1995) MEAN $12.53 \quad$ LOW 18.39 (Sept. 12, 1995)

Figure 77.-Water level in observation well 03PP01, Walker County. 


\section{Crystalline-Rock Aquifers}

Water levels in the crystalline-rock aquifers (fig. 78) were monitored in eight wells in 1995, five of which are summarized in figures 79-83. Water levels in wells tapping the crystalline-rock aquifers are affected mainly by precipitation and evapotranspiration, and locally by pumping (Cressler and others, 1983). Precipitation can cause rapid rises in water levels in areas where thin regolith overlies aquifers having secondary openings (Cressler and others, 1983), and the effect is illustrated in the hydrograph for well 11FF04 (fig. 81). The annual mean water levels in these wells (figs. 79-83) ranged from $0.4 \mathrm{ft}$ lower to $0.4 \mathrm{ft}$ higher in 1995 than in 1994 . A record-low daily mean water level was recorded in well $11 \mathrm{FF} 04$ (fig. 81 ) that was $0.1 \mathrm{ft}$ lower than the previous record low.

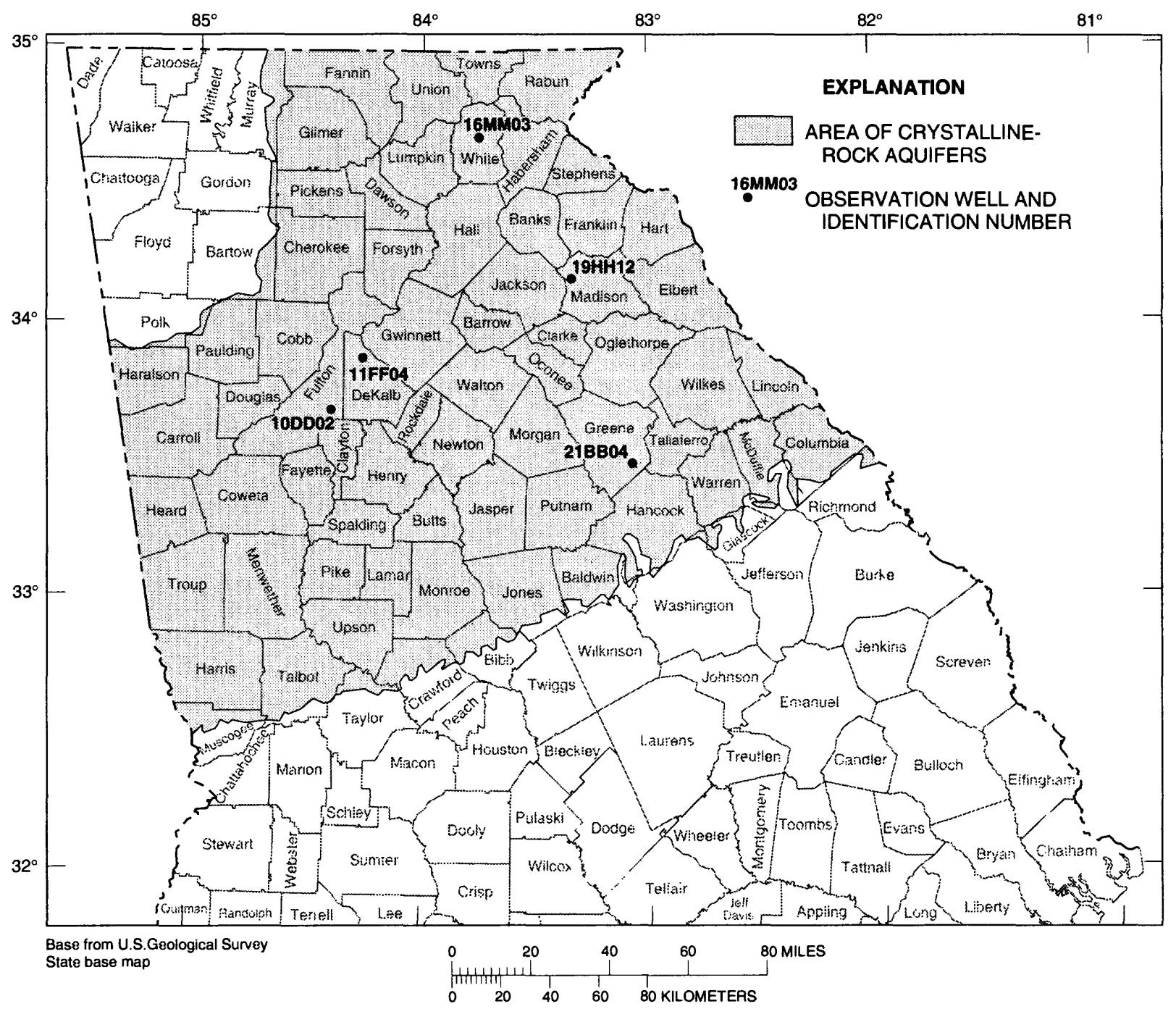

Figure 78.-Locations of observation wells completed in crystalline-rock aquifers. 
334207084254801 Local number, $10 \mathrm{DD} 02$.

LOCATION. - Lat $33^{\circ} 42^{\prime} 07^{\prime \prime}$, long $84^{\circ} 25^{\prime} 48^{\prime \prime}$, Hydrologic Unit 03130002.

SITE NAME.-U.S. Army, Fort McPherson.

INSTRUMENTATION.-Digital recorder.

AQUIFER.-Crystalline rock (biotite gneiss).

WELL CHARACTERISTICS.-Drilled, unused supply well, diameter $12 \mathrm{in}$., depth $338 \mathrm{ft}$, cased to $41 \mathrm{ft}$, open hole.

DATUM.-Altitude of land-surface datum is $1,013 \mathrm{ft}$.

REMARKS.-None.

PERIOD OF RECORD.-November 1973 to current year. Continuous record since November 1973.

EXTREMES FOR PERIOD OF RECORD. - Highest water level, $0.10 \mathrm{ft}$ below land-surface datum, March 30, 1980;

lowest, $10.95 \mathrm{ft}$ below land-surface datum, September 2, 1988.
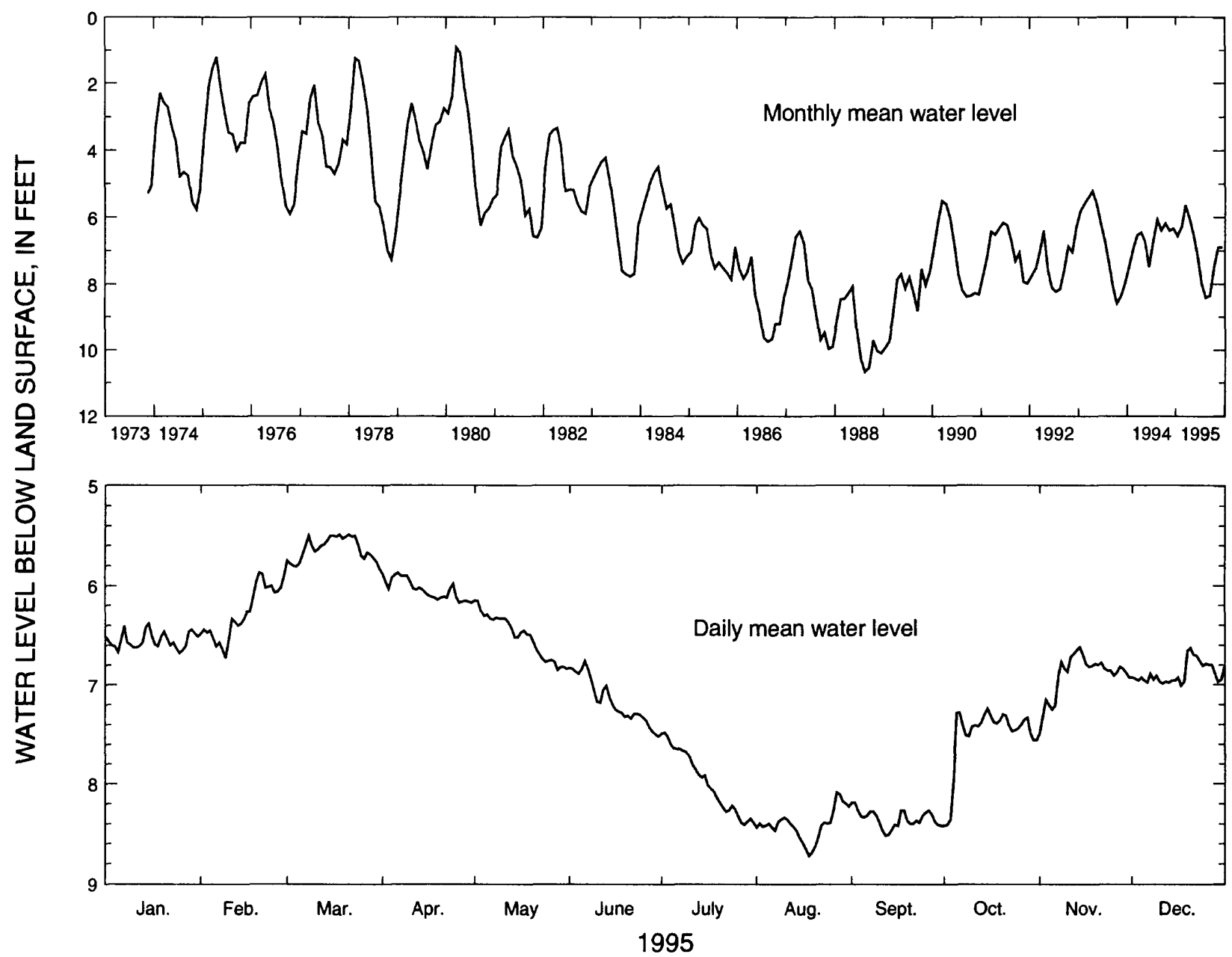

\begin{tabular}{lcccccccccccr}
1995 & JAN & FEB & MAR & APR & MAY & JUNE & JULY & AUG & SEPT & OCT & NOV & DEC \\
HIGH & 6.38 & 5.87 & 5.49 & 5.87 & 6.15 & 6.76 & 7.48 & 8.09 & 8.19 & 7.24 & 6.62 & 6.63 \\
MEAN & 6.55 & 6.28 & 5.63 & 6.04 & 6.51 & 7.16 & 7.99 & 8.41 & 8.35 & 7.51 & 6.90 & 6.89 \\
LOW & 6.68 & 6.73 & 5.83 & 6.17 & 6.85 & 7.52 & 8.41 & 8.72 & 8.52 & 8.42 & 7.49 & 7.01 \\
\multicolumn{1}{l}{ SUMMARY FOR 1995} & HIGH & $5.49(M a r .18,21,1995)$ & MEAN & 7.02 & LOW & 8.72 (Aug. 18, 1995)
\end{tabular}

Figure 79. -Water level in observation well 10DD02, Fulton County. 
341020083201701 Local number, $19 \mathrm{HH} 12$.

LOCATION.-Lat $34^{\circ} 10^{\prime} 20^{\prime \prime}$, long $83^{\circ} 20^{\prime} 17^{\prime \prime}$, Hydrologic Unit 03060104.

SITE NAME.-Meadowlake Estates.

INSTRUMENTATION.-Digital recorder.

AQUIFER.-Crystalline rock.

WELL CHARACTERISTICS.-Drilled, unused supply well, diameter 6 in., depth $185 \mathrm{ft}$, cased to $50 \mathrm{ft}$, open hole.

DATUM.-Altitude of land-surface datum is $800 \mathrm{ft}$.

REMARKS.-None.

PERIOD OF RECORD.-October 1983 to current year. Continuous record since October 1983.

EXTREMES FOR PERIOD OF RECORD.-Highest water level, $6.69 \mathrm{ft}$ below land-surface datum, April 14, 1984;

lowest, $15.56 \mathrm{ft}$ below land-surface datum, September 2-3, 1988.
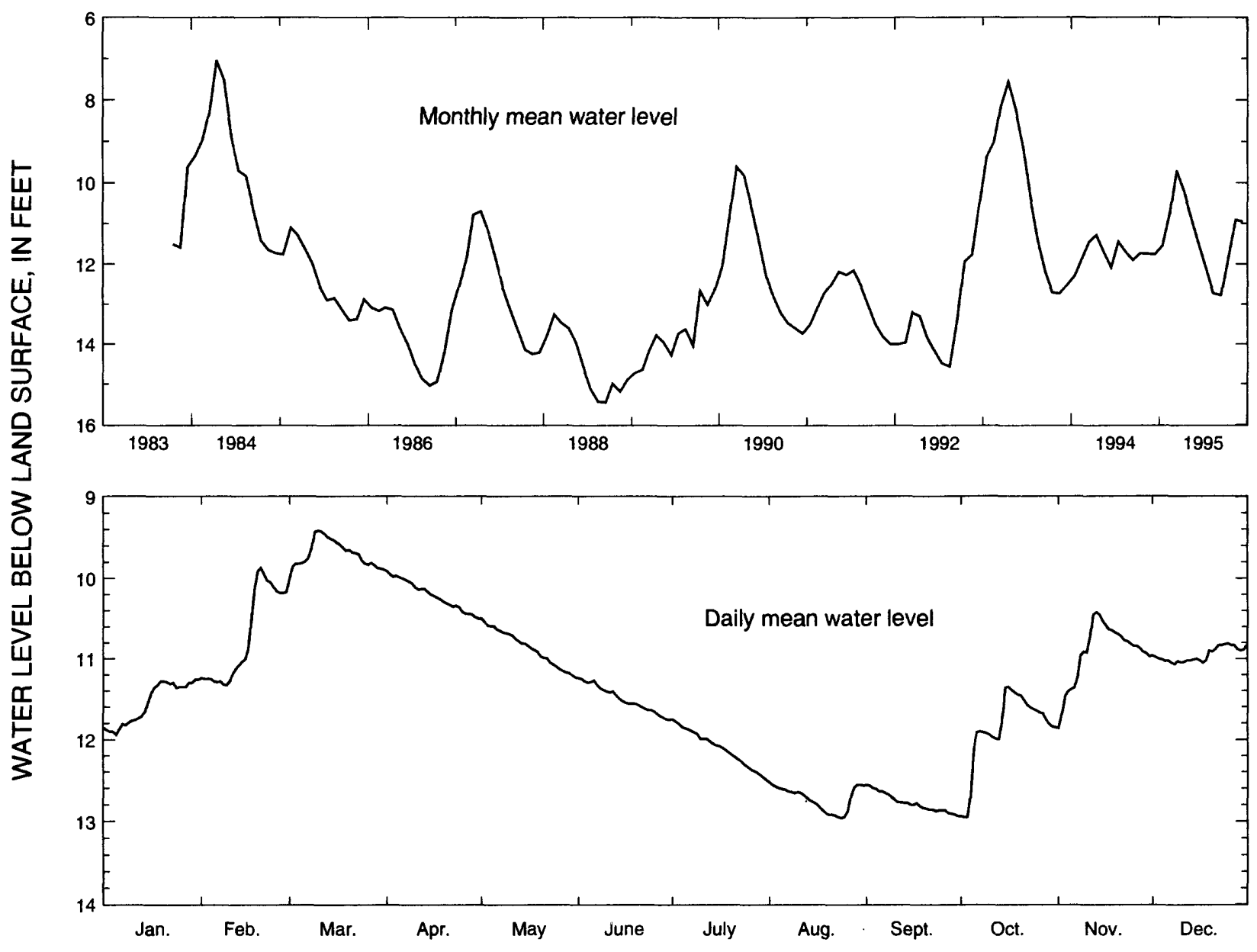

\begin{tabular}{|c|c|c|c|c|c|c|c|c|c|c|c|c|}
\hline 1995 & JAN & FEB & MAR & APR & MAY & JUNE & JULY & $A \cup G$ & SEPT & OCT & NOV & DEC \\
\hline $\begin{array}{l}\text { GGH } \\
\text { EAN }\end{array}$ & $\begin{array}{l}11.26 \\
11.55\end{array}$ & $\begin{array}{r}9.87 \\
10.73\end{array}$ & $\begin{array}{l}9.41 \\
9.70\end{array}$ & $\begin{array}{r}9.91 \\
10.21\end{array}$ & $\begin{array}{l}10.50 \\
10.86\end{array}$ & $\begin{array}{l}11.24 \\
11.50\end{array}$ & $\begin{array}{l}11.75 \\
12.11\end{array}$ & & & & $\begin{array}{l}10.42 \\
10.91\end{array}$ & $\begin{array}{l}10.81 \\
10.95\end{array}$ \\
\hline OW & 11.94 & 11.33 & 10.01 & 10.50 & 11.23 & 11.76 & 12.50 & 12.96 & 12.94 & 12.95 & 11.86 & 11.07 \\
\hline IMA & & & & $11 \mathrm{Mr}$ & 100 & & EAN & 33 & LOW & 12.9 & 21 & 95) \\
\hline
\end{tabular}

Figure 80. -Water level in observation well 19HH12, Madison County. 
335517084164001 Local number, 11 FF04.

LOCATION.-Lat $33^{\circ} 55^{\prime} 17^{\prime \prime}$, long $84^{\circ} 16^{\prime} 40^{\prime \prime}$, Hydrologic Unit 03130001.

SITE NAME.-U.S. Geological Survey, test well 5.

INSTRUMENTATION.-Digital recorder.

AQUIFER.-Crystalline rock.

WELL CHARACTERISTICS.-Drilled, observation well, diameter 6 in., depth $620 \mathrm{ft}$, cased to $36 \mathrm{ft}$, open hole.

DATUM.-Altitude of land-surface datum is $950 \mathrm{ft}$.

REMARKS.-Water levels for period, May 4 to June 5, are missing.

PERIOD OF RECORD.-February 1980 to current year. Continuous record since February 1980.

EXTREMES FOR PERIOD OF RECORD.-Highest water level, $4.98 \mathrm{ft}$ below land-surface datum, March 17, 1990;

lowest, $7.85 \mathrm{ft}$ below land-surface datum, August 18, 1995.
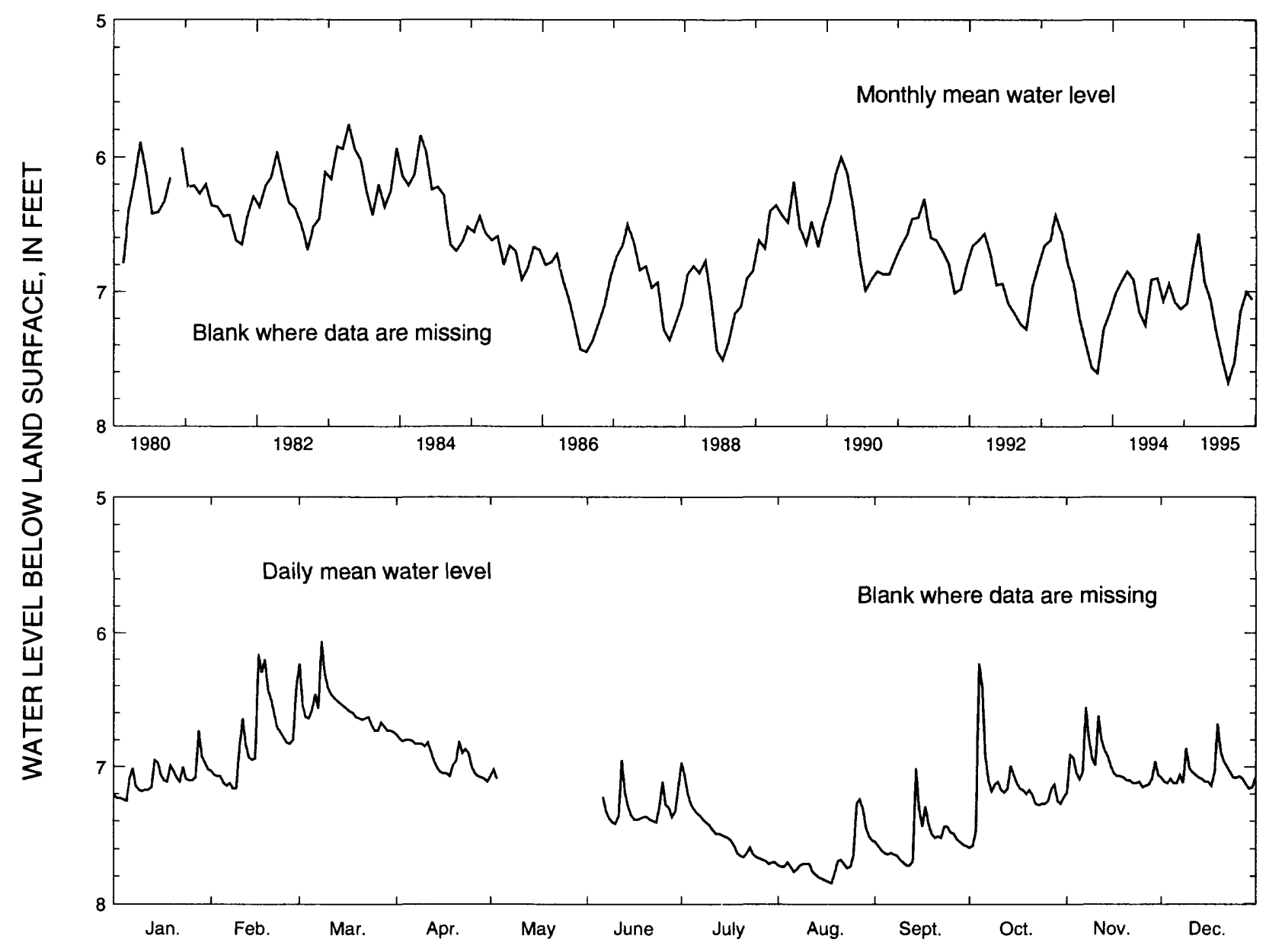

\begin{tabular}{|c|c|c|c|c|c|c|c|c|c|c|c|c|}
\hline 1995 & JAN & FEB & MAR & APR & MAY & JUNE & JULY & AUG & SEPT & OCT & NOV & DEC \\
\hline$H I G$ & 6.73 & 6.16 & $\begin{array}{l}6.06 \\
657\end{array}$ & 6.76 & --..- & 6.95 & 6.97 & $\begin{array}{l}7.24 \\
7.68\end{array}$ & 7.01 & $\begin{array}{r}6.23 \\
7.15\end{array}$ & 6.56 & 68 \\
\hline $\begin{array}{l}\text { IEAN } \\
\text { OW }\end{array}$ & $\begin{array}{l}7.09 \\
7.25\end{array}$ & $\begin{array}{l}6.80 \\
7.16\end{array}$ & $\begin{array}{l}6.57 \\
6.74\end{array}$ & $\begin{array}{l}6.93 \\
7.11\end{array}$ & ----.- & $\begin{array}{l}7.31 \\
7.42\end{array}$ & $\begin{array}{l}7.50 \\
7.71\end{array}$ & $\begin{array}{l}7.68 \\
7.85\end{array}$ & $\begin{array}{l}7.53 \\
7.72\end{array}$ & $\begin{array}{l}7.15 \\
7.59\end{array}$ & $\begin{array}{l}7.00 \\
7.19\end{array}$ & $\begin{array}{l}7.06 \\
7.16\end{array}$ \\
\hline JMN & OR & & \multicolumn{3}{|c|}{ HIGH 6.06 (Mar. 8, 1995) } & \multicolumn{3}{|c|}{ MEAN 7.15} & \multicolumn{3}{|c|}{ LOW 7.85 (Aug. 18, 1995) } & \\
\hline
\end{tabular}

Figure 81.-Water level in observation well 11FF04, DeKalb County. 
332808083010201 Local number, $21 \mathrm{BB} 04$.

LOCATION.-Lat $33^{\circ} 28^{\prime} 08^{\prime \prime}$, long $83^{\circ} 01^{\prime} 02^{\prime \prime}$, Hydrologic Unit 03070101.

SITE NAME.-Charles Veazey.

INSTRUMENTATION.-Analog recorder.

AQUIFER.-Crystalline rock.

WELL CHARACTERISTICS. - Drilled, unused supply well, diameter 6 in., depth $497 \mathrm{ft}$, cased to $15 \mathrm{ft}$, open hole.

DATUM.-Altitude of land-surface datum is $675 \mathrm{ft}$.

REMARKS.-Water levels for periods, January 4-8, 24-28, February 1-4, 8-11, and June 9-24, are missing.

PERIOD OF RECORD.-March 1987 to current year. Continuous record since March 1987.

EXTREMES FOR PERIOD OF RECORD.-Highest water level, $1.25 \mathrm{ft}$ above land-surface datum, March 28, 1993;

lowest, $7.58 \mathrm{ft}$ below land-surface datum, December 7, 1987.
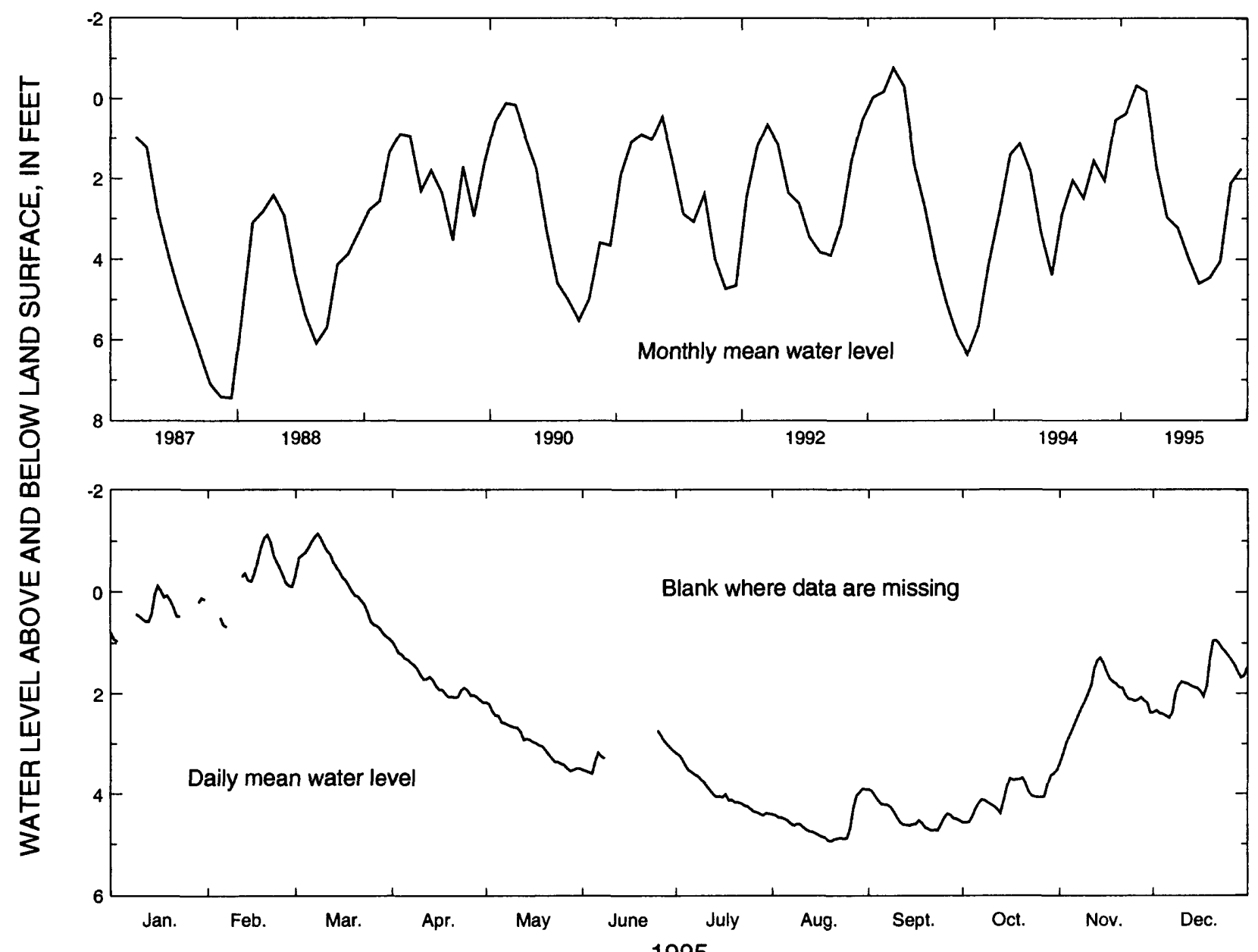

\begin{tabular}{|c|c|c|c|c|c|c|c|c|c|c|c|c|}
\hline 1995 & JAN & FEB & MAR & APR & MAY & JUNE & JULY & $A \cup G$ & SEPT & OCT & NOV & DEC \\
\hline $\mathrm{HIGH}$ & -...... & $\ldots$ & -1.14 & 0.97 & 2.17 & -..-.- & 3.19 & 3.90 & 3.91 & 3.53 & 1.28 & 0.94 \\
\hline MEAN & ....... & ....... & -0.20 & 1.73 & 2.96 & ....... & 3.96 & 4.60 & 4.45 & 4.05 & 2.12 & 1.75 \\
\hline LOW & -...-.. & -.--.- & 0.91 & 2.17 & 3.55 & ------ & 4.43 & 4.94 & 4.73 & 4.57 & 3.38 & 2.48 \\
\hline MN & סר & & $\mathrm{g}$ & & 95) & & MEAN ? & & LOW & $\left(A_{l}\right.$ & $0,1995)$ & \\
\hline
\end{tabular}

Figure 82.-Water level in observation well 21BB04, Greene County. 
344314083433201 Local number, 16MM03.

LOCATION.-Lat $34^{\circ} 43^{\prime} 14^{\prime \prime}$, long $83^{\circ} 43^{\prime} 32^{\prime \prime}$, Hydrologic Unit 03130001.

SITE NAME.-Unicoi State Park, well 4.

INSTRUMENTATION.-Digital recorder.

AQUIFER.-Crystalline rock.

WELL CHARACTERISTICS.-Drilled, unused supply well, diameter $6.25 \mathrm{in}$., depth $400 \mathrm{ft}$, cased to $72 \mathrm{ft}$, open hole. DATUM.-Altitude of land-surface datum is $1550 \mathrm{ft}$.

REMARKS.-None.

PERIOD OF RECORD.-May 1988 to current year. Continuous record since May 1988.

EXTREMES FOR PERIOD OF RECORD.- - Highest water level, $0.74 \mathrm{ft}$ above land-surface datum, March 17, 1989; lowest, $5.59 \mathrm{ft}$ below land-surface datum, September 2, 1988.
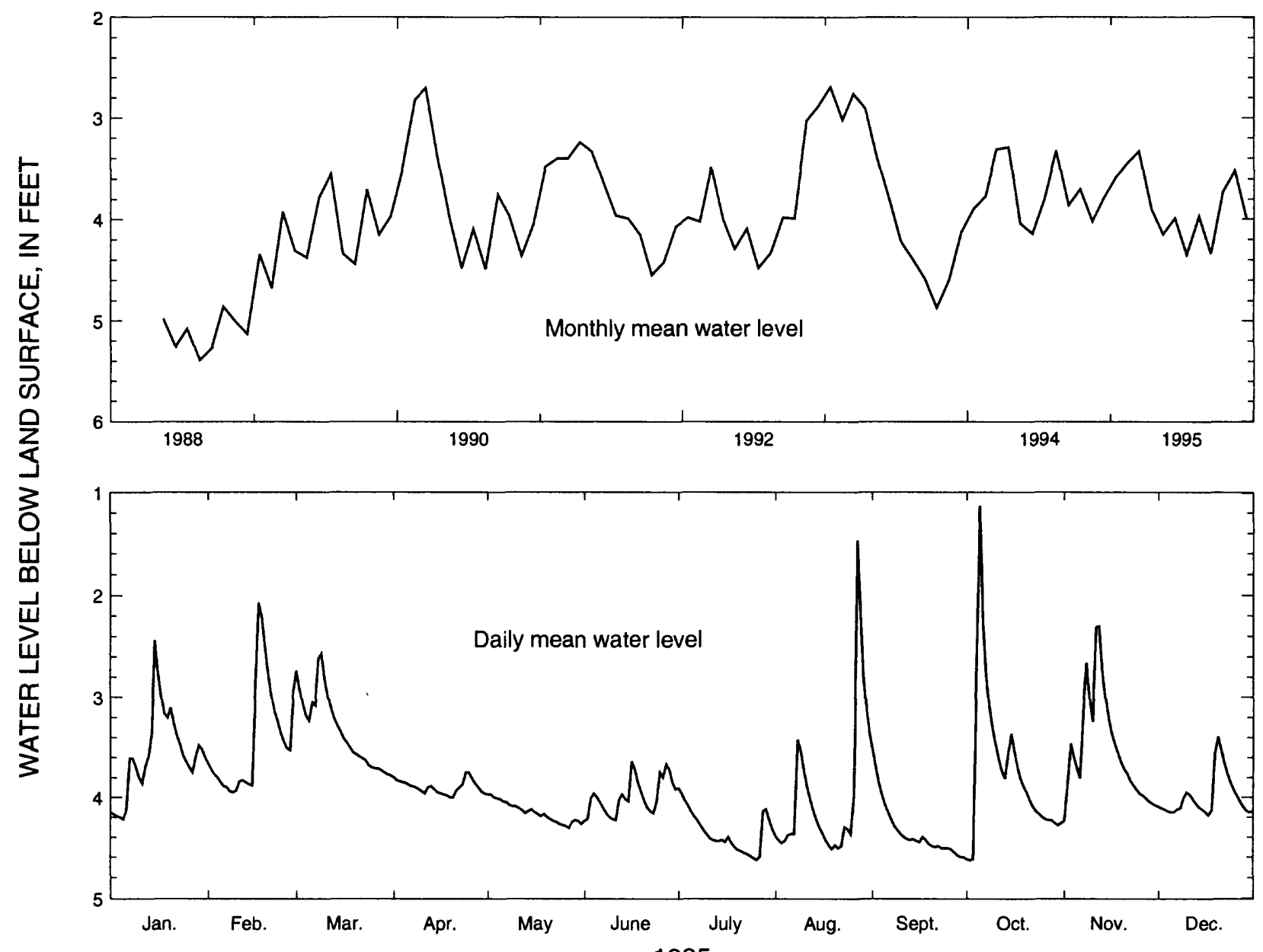

\begin{tabular}{lcccccccccccc}
1995 & JAN & FEB & MAR & APR & MAY & JUNE & JULY & AUG & SEPT & OCT & NOV & DEC \\
HIGH & 2.44 & 2.07 & 2.57 & 3.75 & 3.97 & 3.64 & 3.91 & 1.47 & 3.52 & 1.13 & 2.30 & 3.39 \\
MEAN & 3.58 & 3.44 & 3.33 & 3.90 & 4.15 & 3.99 & 4.35 & 3.97 & 4.34 & 3.73 & 3.52 & 4.00 \\
LOW & 4.22 & 3.95 & 3.78 & 4.00 & 4.31 & 4.24 & 4.63 & 4.52 & 4.60 & 4.63 & 4.24 & 4.18 \\
\multicolumn{3}{l}{ SUMMARY FOR 1995 } & \multicolumn{3}{c}{ HIGH 1.13 (Oct. 5, 1995) } & \multicolumn{3}{c}{ MEAN 3.86 } & LOW 4.63 (July 26, 1995)
\end{tabular}

Figure 83.-Water level in observation well 16MM03, White County. 


\section{CHLORIDE CONCENTRATION IN WATER FROM THE FLORIDAN AQUIFER SYSTEM}

Chloride concentration in water from the Floridan aquifer system has been monitored in coastal Georgia since the 1950's. During 1994, water samples were collected from 20 wells that tap the Floridan aquifer system in the Savannah and Brunswick areas and analyzed for chloride concentration. Graphs of chloride concentration in water for 13 of these wells (fig. 84; table 4) are shown in figures 85,87 , and 88. Although chloride concentration may fluctuate in the intervals between sample-collection periods, measured points on these plots are connected by straight lines to assist visualization. Chloride concentration in water from the Upper Floridan aquifer in most of the coastal Georgia area is less than 40 milligrams per liter $(\mathrm{mg} / \mathrm{L})$ (Clarke and others, 1990, p. 48), which is lower than the 250 $\mathrm{mg} / \mathrm{L}$ drinking-water standards established by the Georgia Department of Natural Resources (1977) and the U.S. Environmental Protection Agency (1990). Chloride concentration in water from the Upper Floridan aquifer that exceeds drinking-water standards has been detected in the Brunswick area. Water in the Lower Floridan aquifer generally has high chloride concentration in the Savannah and Brunswick areas. Chloride concentration in water from the Fernandina permeable zone at the base of the Lower Floridan aquifer has been measured as high as 30,000 $\mathrm{mg} / \mathrm{L}$ (Krause and Randolph, 1989, p. D51).

Table 4. Observation wells for which chloride-concentration graphs are included in this report

\begin{tabular}{lllll}
\hline County & \multicolumn{1}{c}{ Aquifer } & $\begin{array}{c}\text { Well } \\
\text { number }\end{array}$ & Site name & $\begin{array}{c}\text { Well depth } \\
\text { (in feet) }\end{array}$ \\
\hline Chatham & Lower Floridan & 38 Q196 & USGS, test well 1, point 2 & $870-925$ \\
Chatham & Lower Floridan & 39 Q017 & USGS, test well 7, point 1 & $710-745$ \\
Chatham & Lower Floridan & 39 Q018 & USGS, test well 7, point 2 & $630-670$ \\
Chatham & Lower Floridan & 38 Q004 & USGS, test well 4 & $606-657$ \\
Chatham & Upper Floridan & 37 Q185 & GGS, Hutchinson Island, test well 1 & $274-360$ \\
Glynn & Upper Floridan, upper water-bearing zone & $34 \mathrm{H} 393$ & USGS, test well 17 & $615-723$ \\
Glynn & Upper Floridan, lower water-bearing zone & $34 \mathrm{H} 403$ & USGS, test well 24 & $788-982$ \\
Glynn & Lower Floridan & $34 \mathrm{H} 399$ & USGS, test well 19 & $1,075-1,218$ \\
Glynn & Lower Floridan & $34 \mathrm{H} 391$ & USGS, test well 16 & $1,070-1,159$ \\
Glynn & Upper Floridan, upper water-bearing zone & $34 \mathrm{H} 469$ & USGS, test well 2 & $540-566$ \\
Glynn & Upper Floridan, upper water-bearing zone & $34 \mathrm{H} 427$ & E.M. Champion, well 2 & $500-640$ \\
Glynn & Upper Floridan, upper water-bearing zone & $33 H 133$ & USGS, test well 6 & $520-790$ \\
Glynn & Upper Floridan, lower water-bearing zone & $33 H 127$ & USGS, test well 3 & $823-925$ \\
\hline
\end{tabular}




\section{Savannah Area}

Twelve wells currently are sampled semi-annually in Chatham County (fig. 84); five of which are summarized in figure 85. Data from these wells indicate that chloride concentration generally increases with depth below land surface and is not changing appreciably with time (fig. 85).

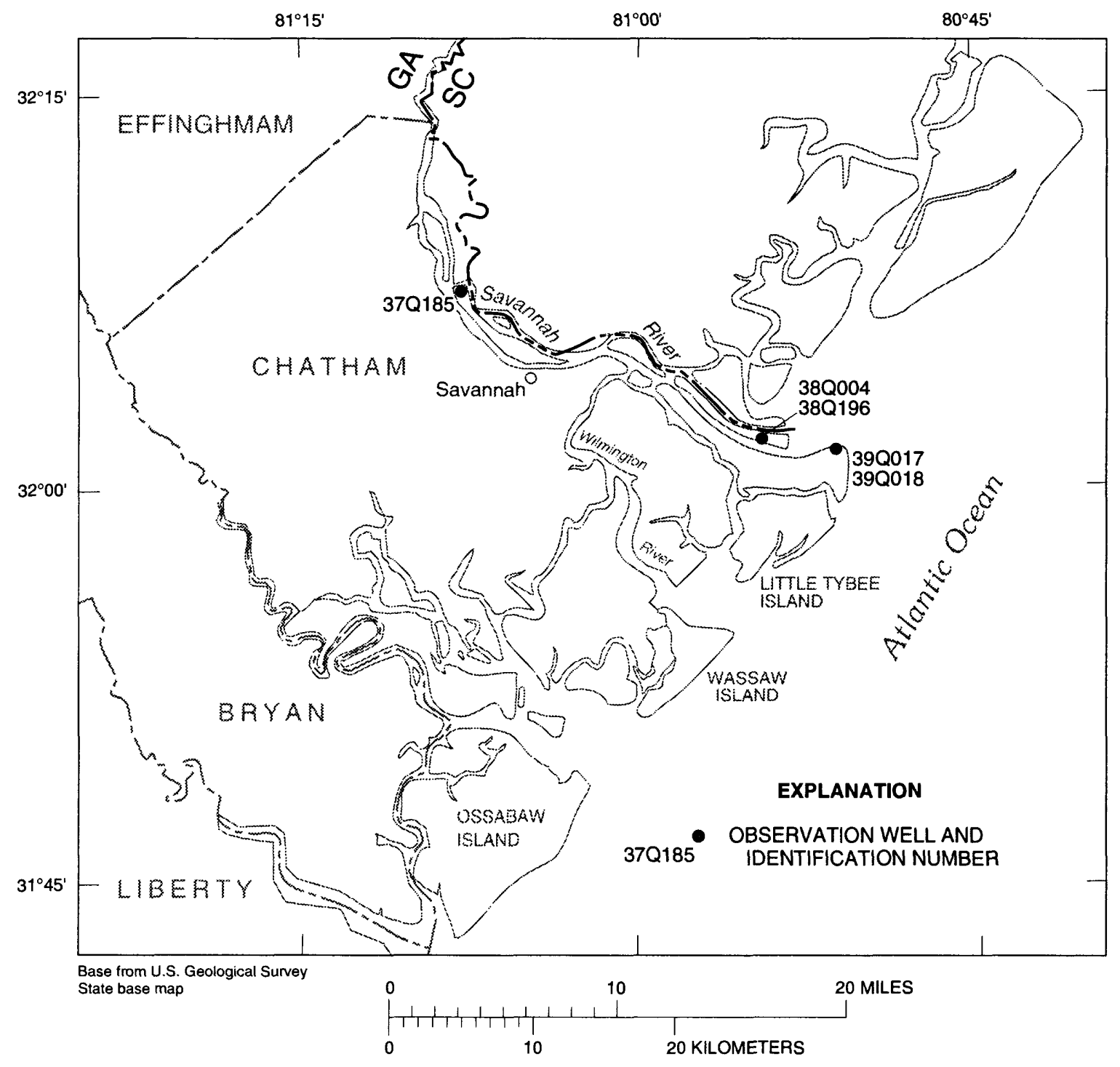

Figure 84.-Locations of chloride-monitoring wells completed in the Floridan aquifer system in the Savannah area. 

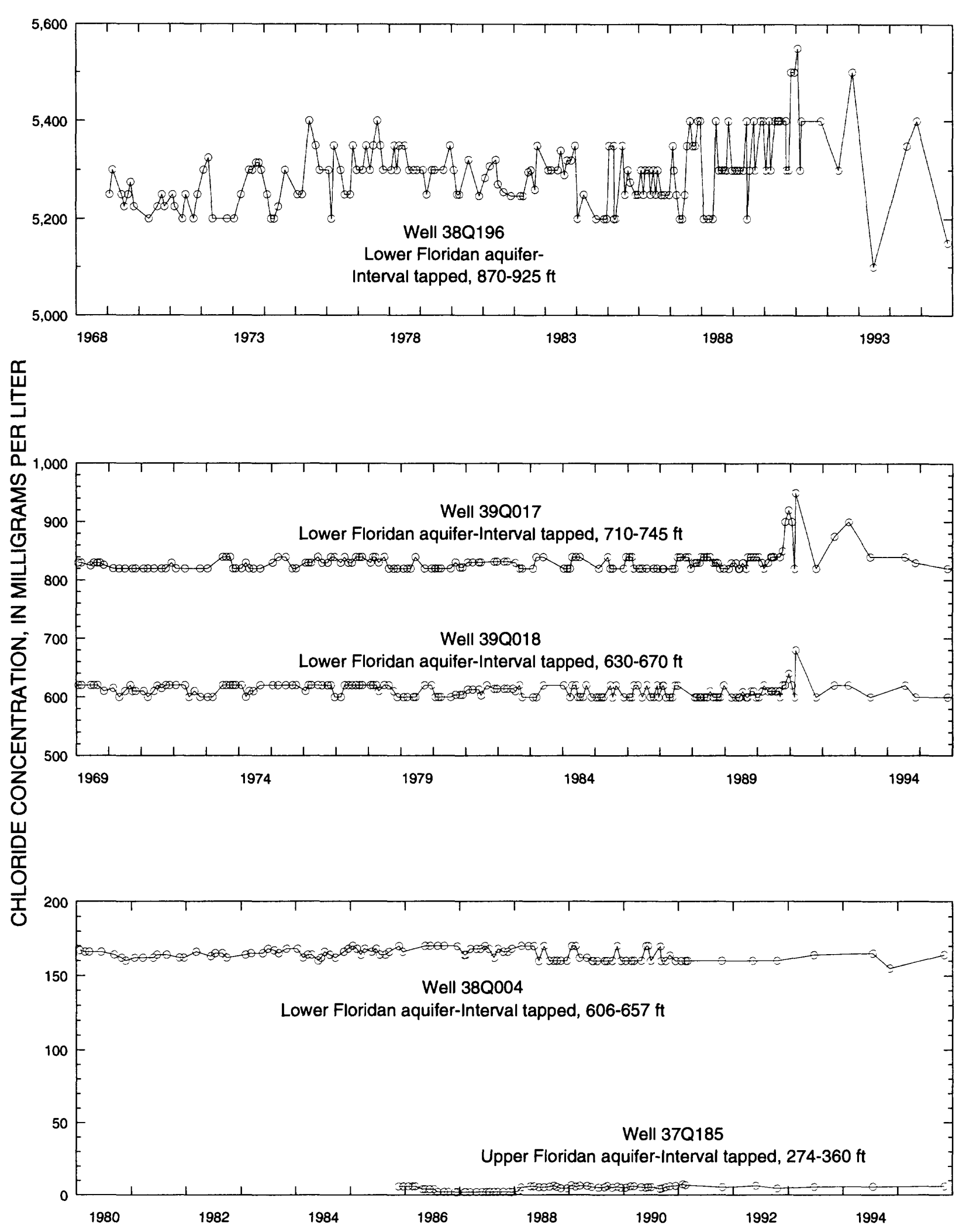

Figure 85.-Chloride concentration in water from the Upper and Lower Floridan aquifers in the Savannah area. 


\section{Brunswick Area}

Since pumping began in the Brunswick area in the late 1800's, ground-water withdrawal has lowered the water level in the Upper Floridan aquifer (Krause and Randolph, 1989). This water-level decline has allowed saltwater to migrate upward into the brackish-water zone of the lower Floridan aquifer and into the Upper Floridan aquifer in Brunswick from the Fernandina permeable zone, which is at the base of the Lower Floridan aquifer (Krause and Randolph, 1989, p. D51). Chloride concentration in water from the upper water-bearing zone of the Upper Floridan aquifer is greater than $2,000 \mathrm{mg} / \mathrm{L}$ in parts of Brunswick.

In the Brunswick, Glynn County area, eight wells (fig. 86) were pumped and sampled during 1995 for chloride analysis. Graphs of chloride concentration in water from those eight wells tapping various zones of the Floridan aquifer system are shown in figures 87 and 88 .

The chloride concentration in water from wells $34 \mathrm{H} 469$ and $34 \mathrm{H} 427$, which tap the upper water-bearing zone of the Upper Floridan aquifer in the northern Brunswick area, are shown in figure 88 . The chloride concentration in water from wells $33 \mathrm{H} 133$ and $33 \mathrm{H} 127$ (fig. 88) which tap the upper and lower water-bearing zones of the Upper Floridan aquifer, respectively, show an upward trend since sampling began in 1966.

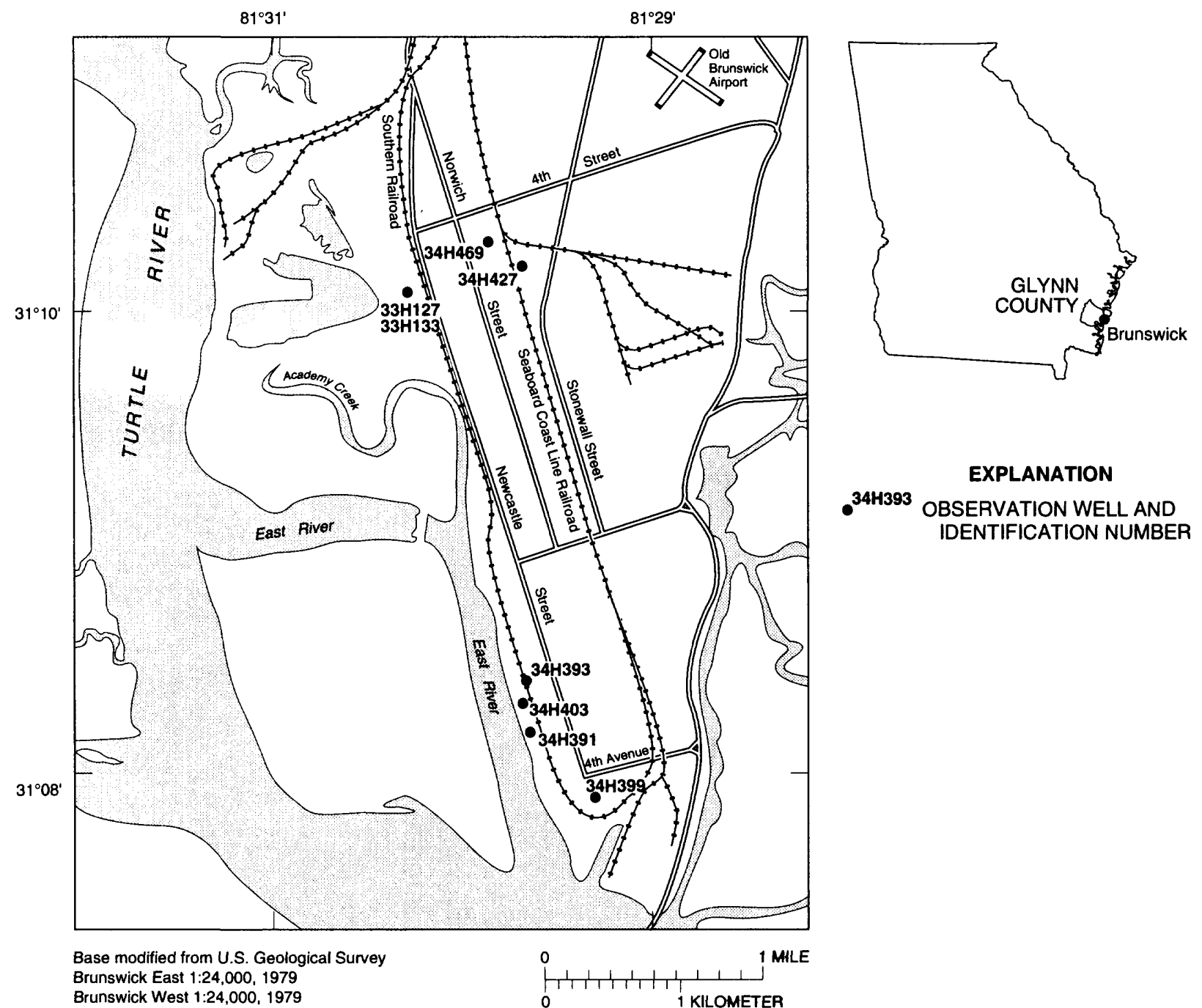

Figure 86.-Locations of chloride-monitoring wells completed in the Floridan aquifer system in the Brunswick area. 


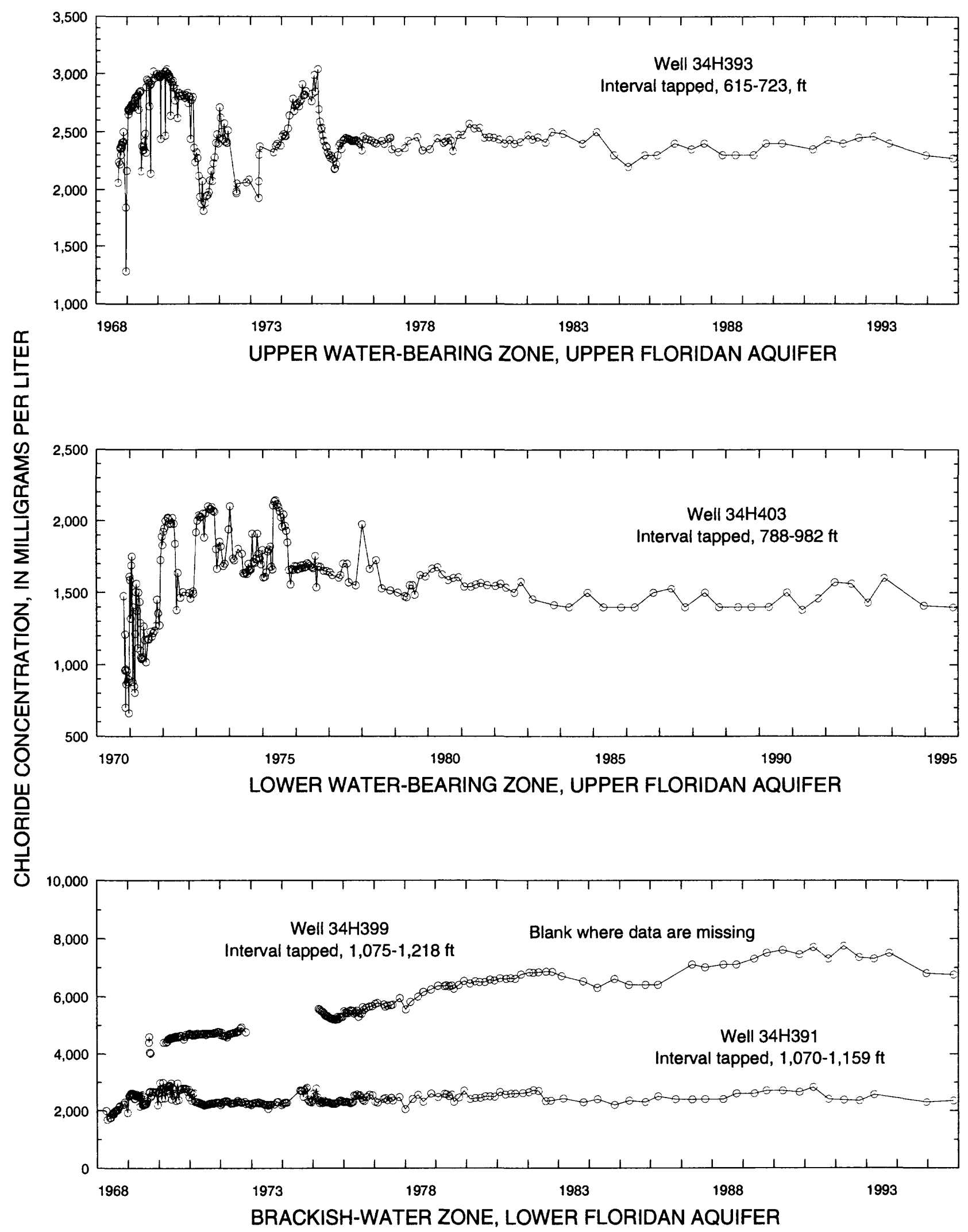

Figure 87.-Chloride concentration in water from the Floridan aquifer system in the southern Brunswick area. 


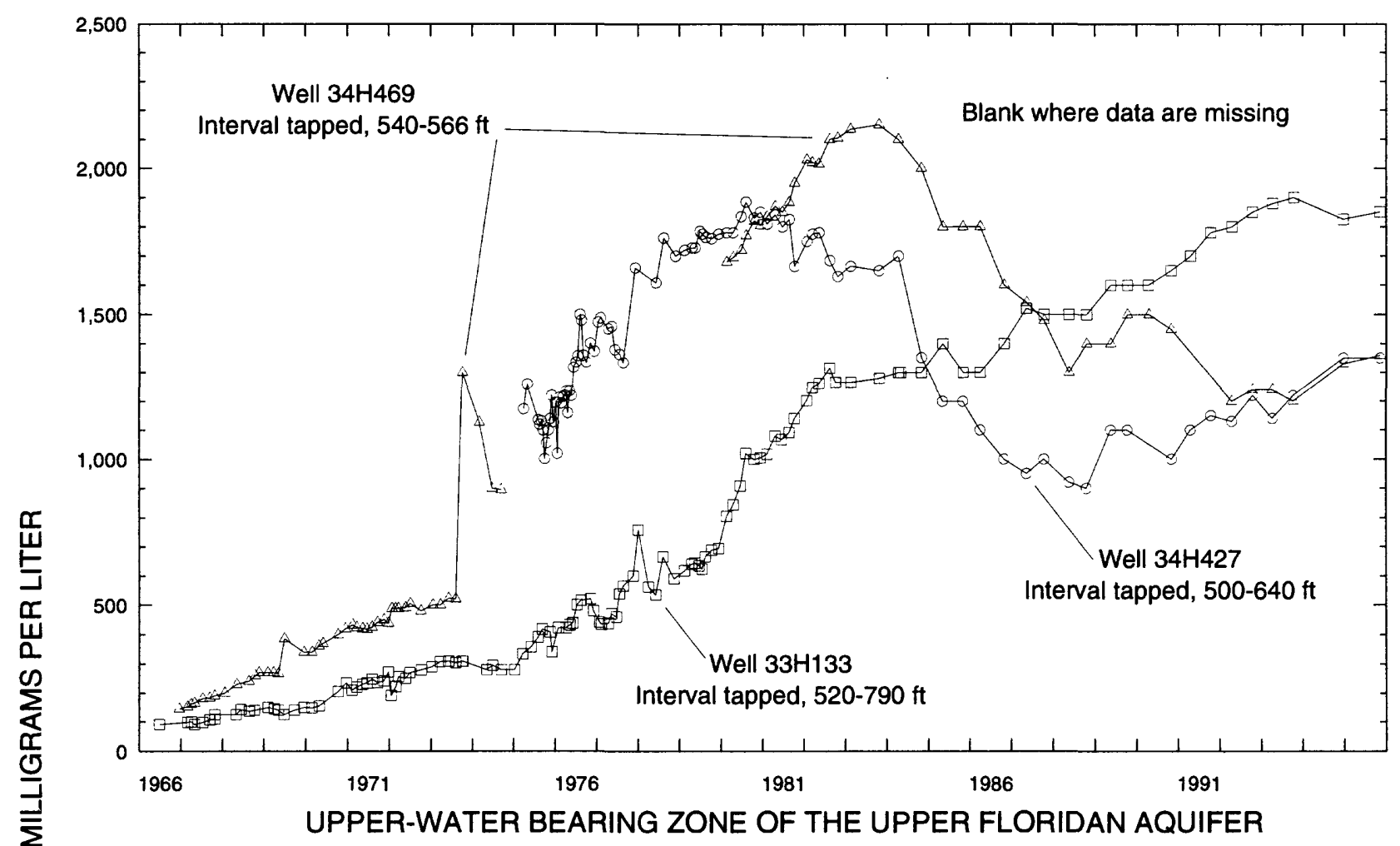

Well $33 \mathrm{H} 127$

Interval tapped, 823-925 ft

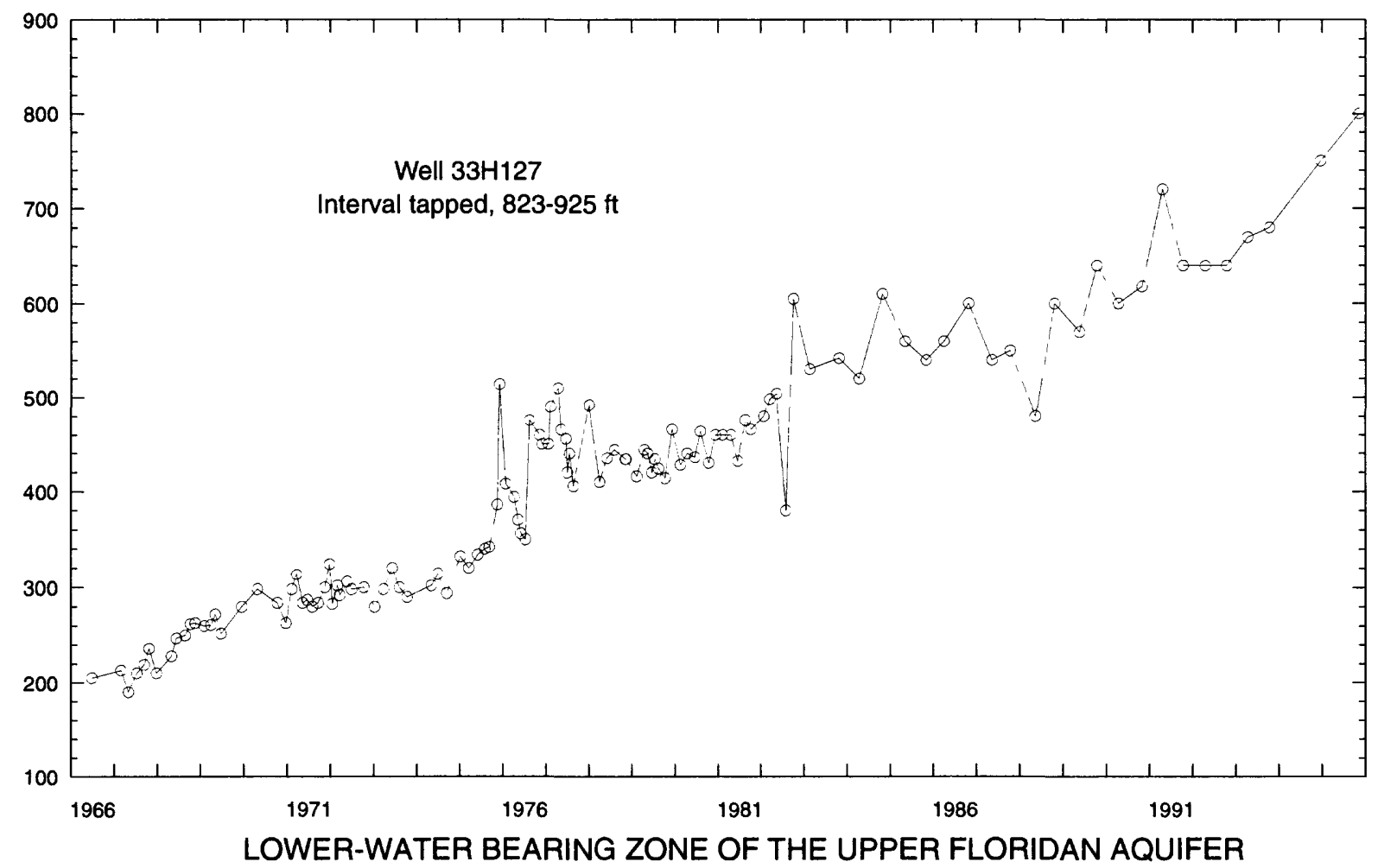

Figure 88. - Chloride concentration in water from the Upper Floridan aquifer in the northern Brunswick area. 


\section{SELECTED REFERENCES}

Brooks, Rebekah, Clarke, J.S., and Faye, R.E., 1985, Hydrogeology of the Gordon aquifer system of east- central Georgia: Georgia Geologic Survey Information Circular 75, 41 p.

Carter, R.F., and Stiles, H.R., 1983, Average annual rainfall and runoff in Georgia, 1941-70: Georgia Geologic Survey Hydrologic Atlas 9, 1 sheet.

Clarke, J.S., 1987, Potentiometric surface of the Upper Floridan aquifer, May 1985, and water-level trends, 1980-85: Georgia Geologic Survey Hydrologic Atlas 16, scale 1:1,000,000, 1 sheet.

Clarke, J.S., Brooks, Rebekah, and Faye, R.E., 1985, Hydrology of the Dublin and Midville aquifer system of eastcentral Georgia: Georgia Geologic Survey Information Circular 74, 62 p.

Clarke, J.S., Faye, R.E., and Brooks, Rebekah, 1983, Hydrogeology of the Providence aquifer of southwest Georgia: Georgia Geologic Survey Hydrologic Atlas 11, 5 sheets.

Clarke, J.S., Hacke, C.M., and Peck, M.F., 1990, Geology and ground-water resources of the coastal area of Georgia: Georgia Geologic Survey Bulletin 113, 106 p.

Clarke, J.S., and Peck, M.F., 1990, Ground-water resources of the south Metropolitan Atlanta region, Georgia: Georgia Geologic Survey Information Circular 88, 56 p.

Clarke, J.S., and Pierce, R.R., 1984, Georgia water facts-ground-water resources in the United States, in National Water Summary, 1984: U.S. Geological Survey Water-Supply Paper 2275, p. 179-184.

Counts, H.B., and Donsky, Ellis, 1963, Salt-water encroachment, geology, and ground-water resources of the Savannah area, Georgia and South Carolina: U.S. Geological Survey Water-Supply Paper 1611, 100 p.

Cressler, A.M., 1991, Chloride concentrations in the Upper Floridan aquifer in the coastal area of Georgia, May 1990: U.S. Geological Survey Open-File Report 91-173, 1 p.

---- 1994, Potentiometric surfaces of the Upper Floridan aquifer, Valdosta area, Georgia, June 3-4, 1991 and March 29 to April 2, 1993: U.S. Geological Survey Water-Resources Investigations Report 93-361, 2 p.

Cressler, A.M., Jones, L.E., and Joiner, C. N., 1995, Ground-water conditions in Georgia, 1994: U.S. Geological Survey Open-File Report 95-302, 135 p.

Cressler, C.W., 1964, Geology and ground-water resources of Walker County, Georgia: Georgia Geologic Survey Information Circular 29, $15 \mathrm{p}$.

Cressler, C.W., Thurmond, C.J., and Hester, W.G., 1983, Ground water in the Greater Atlanta region, Georgia: Georgia Geologic Survey Information Circular 63, 144 p.

Faye, R.E., and McFadden, K.W., 1988, Hydraulic characteristics of Upper Cretaceous and lower tertiary clastic aquifers-eastern Alabama, Georgia, and western South Carolina: U.S. Geological Survey Water-Resources Investigations Report 86-4210, $22 \mathrm{p}$.

Garza, Reggina, and Krause, R.E., 1992, Water-supply potential of major streams and the Upper Floridan aquifer in the vicinity of Savannah, Georgia: U.S. Geological Survey Open-File Report 92-629, 49 p.

Georgia Department of Natural Resources, 1977, Rules for safe drinking water: Atlanta, Ga., Department of Natural Resources, Environmental Protection Division, chap. 391-3-5, p. 601-657.

Gorday, L.L., 1985, The hydrogeology of the Coastal Plain strata of Richmond and northern Burke Counties, Georgia: Georgia Geologic Survey Information Circular 61, 43 p.

---- 1990, The hydrogeology of Lamar County, Georgia: Georgia Geologic Survey Information Circular 80, 40 p.

Grantham, R.G., and Stokes, W.R., III, 1976, Ground-water-quality data for Georgia: Atlanta, Ga., U.S. Geological Survey, unnumbered report, $216 \mathrm{p}$.

Gregg, D.O., and Zimmerman, E.A., 1974, Geologic and hydrologic control of chloride contamination in aquifers at Brunswick, Glynn County, Georgia: U.S. Geological Survey Water-Supply Paper 2029-D, 44 p.

Hayes, R.H., Maslia, M.L., and Meeks, W.C., 1983, Hydrology and model evaluation of the principal artesian aquifer, Dougherty Plain, southwest Georgia: Georgia Geologic Survey Bulletin 97, 93 p.

Hicks, D.W., Krause, R.E., and Clarke, J.S., 1981, Geohydrology of the Albany area, Georgia: Georgia Geologic Survey Information Circular 57, $31 \mathrm{p}$. 


\section{SELECTED REFERENCES-Continued}

Hicks, D.W., Gill, H.E., and Longsworth, S.A., 1987, Hydrology, chemical quality, and availability of ground water in the Upper Floridan aquifer, Albany area, Georgia: U.S. Geological Survey Water-Resources Investigations Report 87-4145, $52 \mathrm{p}$.

Joiner, C. N., 1991, Chloride concentrations in the upper water-bearing zone of the Upper Floridan aquifer in the Brunswick area, Georgia, October-November 1990: U.S. Geological Survey Open-File Report 91-174, 1 p.

Jones, L. E., and Maslia, M.L., 1994, Selected ground-water data, and results of aquifer tests for the Upper Floridan aquifer, Brunswick, Glynn County, Georgia area: U.S. Geological Survey Open-File Report 94-520, 107 p.

Krause, R.E., 1972, Effects of ground-water pumping in parts of Liberty and McIntosh Counties, Georgia, 1966-70: Georgia Geologic Survey Information Circular 45, 15 p.

-.- 1979, Geohydrology of Brooks, Lowndes, and western Echols Counties, Georgia: U.S. Geological Survey WaterResources Investigations Report 78-117, 48 p.

Krause, R.E., and Randolph, R.B., 1989, Hydrogeology of the Floridan aquifer system in southeast Georgia and adjacent parts of Florida and South Carolina: U.S. Geological Survey Professional Paper 1403-D, 65 p.

Mack, D.M., and Karp, H.C., Jr., 1984, Structure-contour map of the top of the Miocene aquifer, in Arora, Ram, ed., Hydrogeologic evaluation for underground injection control in the Coastal Plain of Georgia: Georgia Geologic Survey Hydrologic Atlas 10, plate 5.

Marella, R.L., Fanning, J.L. and Mooty, W.S., 1993, Estimated use of water in the Apalachicola-Chattahoochee-Flint River Basin during 1990 with state summaries from 1970 to 1990: U.S. Geological Survey Water Resources Investigation Report 93-4084, 45 p.

Maslia, M.L., and Hayes, L.R., 1986, Hydrogeology and simulated effects of ground-water development of the Floridan aquifer system, southwest Georgia, northwest Florida, and extreme southern Alabama: U.S. Geological Survey Professional Paper 1403-H, 71 p.

McCollum, M.J., and Counts, H.B., 1964, Relation of salt-water encroachment to the major aquifer zones, Savannah area, Georgia and South Carolina: U.S. Geological Survey Water-Supply Paper 1613-D, 26 p.

Miller, J.A., 1986, Hydrogeologic framework of the Floridan aquifer system in Florida and parts of Georgia, Alabama, and South Carolina: U.S. Geological Survey Professional Paper 1403-B, 91 p.

Peck, M.F., 1991, Potentiometric surface of the Upper Floridan aquifer in Georgia and adjacent parts of Alabama, Florida, and South Carolina, May-June 1990: U.S. Geological Survey Open-File Report 91-206, 3 p.

Peck, M.F., and Allen, R.J., 1991, Potentiometric surface of the Clayton aquifer in Georgia, October 1990: U.S. Geological Survey Open-File Report 91-208, 2 p.

Peck, M.F., Joiner, C.N., and Cressler A.M., 1992 Ground-water conditions In Georgia, 1991: U.S. Geological Survey Open-File Report 92-470, 137 p.

Peck, M.F., and Cressler, A.M., 1993, Ground-water conditions in Georgia, 1992: U.S. Geological Survey Open-File Report 93-358, 134 p.

Peck, M.F., and Garrett, J.W., 1994, Quality of surface and ground water in the White Creek and Mossy Creek watersheds, White County, Georgia, 1992-93: U.S. Geological Survey Open-File Report 94-540, 31 p.

Randolph, R.B., and Krause, R.E., 1984, Analysis of the effects of proposed pumping from the principal artesian aquifer, Savannah, Georgia area: U.S. Geological Survey Water-Resources Investigations Report 84-4064, 26 p.

--- 1990, Analysis of the effects of hypothetical changes in ground-water withdrawal from the Floridan aquifer system in the area of Glynn County, Georgia: U.S. Geological Survey Water-Resources Investigations Report 90-4027, $32 \mathrm{p}$.

Radtke, D.B., Cressler, C.W., Perlman, H.A., Blanchard, H.E., Jr., McFadden, K.W., and Brooks, Rebekah, 1986, Occurrence and availability of ground water in the Athens region, northeastern Georgia: U.S. Geological Survey Water-Resources Investigations Report 86-4075, 79 p. 


\section{SELECTED REFERENCES-Continued}

Torak, L.J., Davis, G.S., Strain, G.A., and Herndon, J.G., 1991, Geohydrology and evaluation of water-resource potential of the Upper Floridan aquifer in the Albany area, southwestern Georgia: U.S. Geological Survey Water-Supply Paper 2391, 59 p.

Vorhis, R.C., 1973, Geohydrology of Sumter, Dooly, Pulaski, Lee, Crisp, and Wilcox Counties, Georgia: U.S. Geological Survey Hydrologic Investigations Atlas HA-435, 1 sheet.

Wait, R.L., and Gregg, D.O., 1973, Hydrology and chloride contamination of the principal artesian aquifer in Glynn County, Georgia: Georgia Geologic Survey Hydrologic Report 1, 21 p.

Watson, T.W., 1984, Hydrogeology of Greene, Morgan, and Putnam Counties: Georgia Geologic Survey Information Circular 60, $16 \mathrm{p}$.

U.S. Environmental Protection Agency, 1990, Drinking water regulations under the Safe Drinking Water Act: Washington, D.C., U.S. Environmental Protection Agency, Criteria and Standards Division, Office of Drinking Water, SDWA Fact Sheet, $45 \mathrm{p}$. 